UNIVERSIDADE DE SÃo PAULO

FACULDADE DE EDUCAÇÃO

MARCELO RITO

CARNE RECORTADA, ALMAS EXPOSTAS:

da visualização escolanovista à utopia do homem aprimorável 
MARCELO RITO

\section{CARNE RECORTADA, ALMAS EXPOSTAS: \\ da visualização escolanovista à utopia do homem aprimorável}

Tese apresentada à Faculdade de Educação da Universidade de São Paulo para obtenção do título de Doutor em Educação.

Orientador: Prof. Dr. Julio Groppa Aquino

Versão corrigida

São Paulo

2015 
AUTORIZO A REPRODUÇÃO E DIVULGAÇÃO TOTAL OU PARCIAL DESTE TRABALHO, POR QUALQUER MEIO CONVENCIONAL OU ELETRÔNICO, PARA FINS DE ESTUDO E PESQUISA, DESDE QUE CITADA A FONTE.

Catalogação na Publicação

Serviço de Biblioteca e Documentação

Faculdade de Educação da Universidade de São Paulo

$37.046 \quad$ Rito, Marcelo

R611c Carne recortada, almas expostas: da visualização escolanovista à utopia do homem aprimorável / Marcelo Rito; orientação Julio Groppa Aquino. São Paulo: s. n., 2015.

$214 \mathrm{p}$.

Tese (Doutorado - Programa de Pós-Graduação em Educação. Área de Concentração: Didática, Teorias de Ensino e Práticas Escolares) - Faculdade de Educação da Universidade de São Paulo.

1. Foucault, Michel 2. Psicopedagogia 3. Escola Nova

4. Neurociências 5. Bibliotheca de Educação 6. Lourenço Filho, Manuel Bergstrom I. Aquino, Julio Groppa, orient. 
Nome: RITO, Marcelo

Título: Carne recortada, almas expostas: da visualização escolanovista à utopia do homem aprimorável

Tese apresentada à Faculdade de Educação da Universidade de São Paulo para obtenção do título de Doutor em Educação.

Orientador: Prof. Dr. Julio Groppa Aquino

Aprovado em:

Banca examinadora:

Prof. Dr.

Instituição:

Julgamento:

Assinatura

Prof. Dr.

Instituição:

Julgamento:

Assinatura:

Prof. Dr.

Instituição:

Julgamento:

Assinatura:

Prof. Dr.

Instituição:

Julgamento:

Assinatura:

Prof. Dr. Instituição:

Julgamento: Assinatura: 


\section{Agradecimentos}

Dizer as últimas palavras de um escrito. Finalizar com letras embaçadas toda uma vida de aluno. Do alto da honraria, ceder à tentação de nomear professores, progenitores, descendentes, parentes, colegas, amigos, alunos.

Agradeço aos meus torcedores de primeira ordem, aqueles que a mim passaram confiança e alento. Ultrapassamos a dor, mas saímos dela com fé e trabalho. Obrigado, Carlos Rito Junior, Hilda Biancardi Rito, Carlos Rito Neto, Elvira Rito Rodrigues e Ângelo Antônio Rito Neto.

Agradeço às minhas crianças: Ana Luiza e Mariana. Agora finalmente sabemos para onde foram os meus dias ensolarados. Vocês deram o refresco e a motivação para tanto trabalho.

Agradeço àqueles que conviveram comigo escolas afora, seja no Meninópolis, no Etapa, na FFLCH ou na FEUSP.

Um agradecimento especial aos colegas e amigos da Escola Waldorf Rudolf Steiner. Cantar, dançar, representar, aprender, projetar e debater com vocês me tornou um homem pleno. Vocês colocaram o sorriso que encontraram no meu rosto.

Saúdo o Instituto de Desenvolvimento Waldorf nas figuras de Paula, Melanie e Florencia: infatigáveis e amorosas lutadoras.

Meus alunos: a vocês dedico toda minha carreira, a vocês entreguei os anos mais ricos da minha vida, por vocês espero que esta tese seja lida.

Louvações aos meus amigos de longa data: Carlos Alberto de Oliveira Junior, Alexandre Isidorio Ribeiro, Mário Albanez Junior, Marcelo Rodrigues Anzilotti, Alexandre Rodrigues Anzilotti. Meus pensamentos repousavam em vocês quando o corpo já não suportava.

Agradecimentos infinitos ao nosso grupo de orientação: à Gisela, desde sempre comigo; à Ana Paula, cumplicidade e confiança; ao Sidmar, singeleza e tato; à Juliana, potência ilimitada; ao Fábio, amorosidade contagiante; ao Luiz Paulo, carinho e apego; ao Flavio Tito, certeza e finura; ao Silas, o mais querido; à Sandy, serelepe aprendiz. 
À Elisa, das palavras incríveis, e ao Guilherme, sangue do meu sangue: suas intervenções fundiram-se nas letras deste texto. A presteza, a gentileza e o companheirismo de vocês nunca serão por mim esquecidos.

Uma grata saudação também aos demais genealogistas: Taís, Darian e Zenaide.

Um desbragado obrigado à Silvia, à Eliane, ao José Carlos, à Rosana, ao Paulo Tadeu e à Beth: minha reserva de otimismo e doçura.

Um respeitoso reconhecimento à banca examinadora deste trabalho: Carlota Boto, Ana Laura Godinho Lima, Maria Rita de Assis César e Maura Corsini Lopes.

Reverências ao pensamento sempre inspirador de Jorge Ramos do Ó.

Em nome de todos os meus torcedores, descendentes, parentes, colegas, amigos e companheiros, sou especialmente grato a Julio Groppa Aquino, que com seu exemplo me ensinou como se faz política na seara acadêmica. Julio, sua firmeza e sua coerência são necessárias para que o espaço público da pesquisa se mantenha possível. Quanto ao efeito em mim: uma vida outra, um professor impertinente, um escritor insistente, um lacrimoso aluno. 


\section{Resumo}

RITO, Marcelo. Carne recortada, almas expostas: da visualização escolanovista à utopia do homem aprimorável. 2015. 214f. Tese (Doutorado em Educação) - Faculdade de Educação, Universidade de São Paulo, São Paulo, 2015.

Apropriando-se do gesto arqueogenealógico de Michel Foucault, a presente investigação dedica-se à problematização da performatividade discursiva em torno do encontro entre saúde e educação. Mais especificamente, o estudo debruça-se sobre quatro conjuntos de enunciados, numa intersecção analítica operada por meio da noção de visualização corpórea. O primeiro deles refere-se à medicina anatomoclínica do século XIX, cuja compilação, realizada em periódicos chancelados pela Academia Imperial de Medicina, permitiu destacar determinadas práticas discursivas concernentes à institucionalização do saber-poder médico brasileiro. Estabeleceu-se como segundo campo enunciativo um conjunto de obras ligadas à psicopedagogia escolanovista, nomeadamente volumes constantes da coleção Bibliotheca de Educação, editados por Lourenço Filho entre 1927 e 1941 com o propósito de estabelecer bases científicas para o sistema educacional brasileiro. O terceiro conjunto de textos centrouse no trato de temas caros à Escola Nova por artigos de 18 periódicos educacionais acadêmicos publicados entre 1993 e 2013. A quarta e última reunião de enunciados foi composta por artigos, livros de divulgação científica e manuais de psiquiatria dedicados a configurar os contornos próprios das relações contemporâneas entre biomedicina e subjetividade. Do ponto de vista analítico, constatou-se que os referidos enunciados estabeleceram incitações a numerosas práticas, as quais aderiram tanto à carne quanto à alma dos corpos por elas alvejados. Concluiu-se, por fim, em favor da hipótese de que os procedimentos próprios da Escola Nova teriam viabilizado a incorporação da psique à anatomia, permitindo, por conseguinte, o despontar, a partir do âmbito educacional, das condições de possibilidade para a emergência de um homem continuamente aprimorável.

Palavras-chave: Saúde; Psicopedagogia; Visualização; Escola Nova; Michel Foucault. 


\begin{abstract}
Cropped flesh, exposed soul: from Escola Nova's kind of visualization to the utopia of the refineable man
\end{abstract}

\begin{abstract}
Making use of the archaeo-genealogical gesture of Michel Foucault, the current research is dedicated to problematize the discursive performativity around the encounter of health with education. In particular, the study focuses on four sets of statements, whose analytical intersection was operated through the notion of corporeal visualization. The first one refers to the anatomoclinical medicine of the Nineteenth century, whose compilation held in official journals of the Academia Imperial de Medicina allowed to witness discursive practices concerning the institutionalization of Brazilian medical knowledge-power. The second set of statements is related to the Escola Nova's psychopedagogy mainly belonging to a book collection named Bibliotheca de Educação, published under the editorship of Lourenço Filho between 1927 and 1941, whose purposes included establishing a scientific basis for the Brazilian educational system. The third set focused on the deal of themes dear to the New School carried out by articles of 18 academic educational journals published between 1993 and 2013. The fourth and final set of statements consisted of articles, popular science books and psychiatry manuals devoted to setting up the very contours of contemporary relations between biomedicine and subjectivity. From an analytical point of view, it was observed that the referred statements incited numerous practices, which adhered both to the flesh and the soul of the bodies targeted by them. Finally, it was concluded in favor of the hypothesis according to which the very procedures of the Escola Nova allowed the incorporation of the psyche by the anatomy, therefore enabling the advent, starting from the educational context, of the conditions of possibility for the emergence of a continuously refineable man.
\end{abstract}

Key-words: Health; Psychopedagogy; Visualization; Escola Nova; Michel Foucault. 


\section{Sumário}

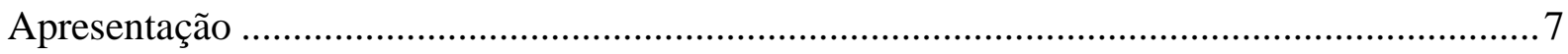

I. Mobilização dos equipamentos: perspectivas teórico-metodológicas .................................. 16

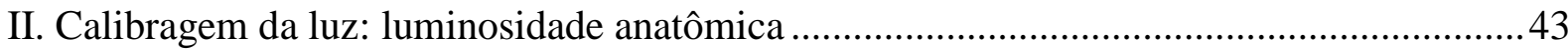

III. Regulação do enfoque: mirada da psicopedagogia escolanovista ......................................66

O foco psicopedagógico da Bibliotheca de Educação........................................................ 72

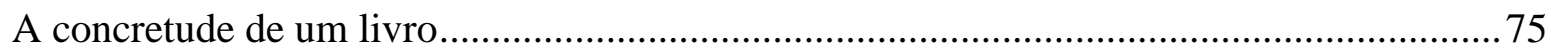

IV. Personagens e enredo: a roupagem acadêmico-pedagógica............................................ 123

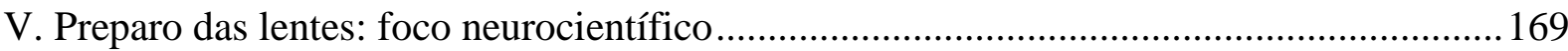

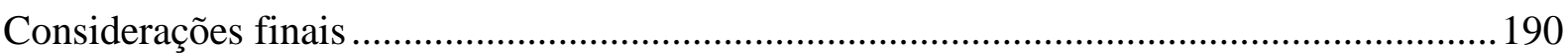

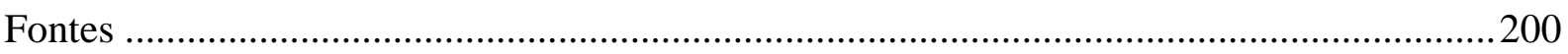

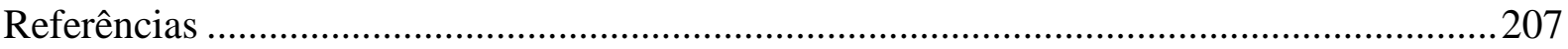


O quadro da vida. - A tarefa de pintar $o$ quadro da vida, por mais que tenha sido proposta pelos escritores e filósofos, é absurda: mesmo pelas mãos dos maiores pintores-pensadores sempre surgiram apenas quadros e miniaturas de uma vida, isto é, da sua vida - e outra coisa não seria possível. Naquilo que está em devir, um ser em devir não pode se refletir como algo firme e duradouro, como um "o".

(Friedrich Nietzsche. Humano, demasiado humano) 


\section{Apresentação}

No primeiro parágrafo de sua biografia, Clifford Whittingham Beers (1934, p. 27) anuncia:

Esta história derivou de um documento humano como jamais existiu outro; e, por causa de sua natureza invulgar, talvez nada contribua tanto para o seu valor quanto a sua autenticidade. É uma autobiografia, e mais: em parte é uma biografia; pois, contando a história da minha vida, fôrça é relatar a história de outro eu - um eu que dominou dos meus vinte e quatro aos meus vinte e seis anos. Durante êsse período não fui o que tinha sido, nem o que tenho sido depois. A parte biográfica da minha autobiografia pode ser chamada a história de uma guerra civil mental, travada por mim sòzinho num campo de batalha situado no recinto do meu crânio. Um exército da Loucura, composto de pensamentos astutos e traiçoeiros de um inimigo desleal, assaltou-me com cruel persistência a conciência aturdida, e ter-me-ia destruído, se uma Razão triunfante não tivesse afinal interposto uma estratégia superior, que me salvou do meu eu inatural.

Nascido em New Haven, Connecticut, em 1876, formado gerente de negócios pela Sheffield Scientific School e falecido em Rhode Island, em 1943, Beers teve sua autobiografia publicada em 1908, na reunião de fundação da Sociedade de Higiene Mental no seu estado. Em 1928, a obra já havia sido reeditada 14 vezes. A primeira edição brasileira foi traduzida por Manuel Bandeira, prefaciada por Afrânio Peixoto e publicada em 1934. Seu título em português: Um espírito que se achou a si mesmo.

A narrativa de Beers, envolvente e instigante, apresenta um cenário de guerra. $\mathrm{O}$ combate entre razão e loucura - que o autor localiza "no recinto do meu crânio" (BEERS, 1934, p. 27) - iniciou-se após um ataque de neurastenia conseguinte à morte de seu irmão por epilepsia. Depois de uma tentativa de suicídio, suas lutas desdobraram-se em um périplo por instituições psiquiátricas.

No auge de seu desempenho profissional, segundo ele, "a vontade teve que capitular à loucura" (p. 39). No tempo em que foi vitoriosa, a loucura conduziu Beers por um mundo à parte, no qual ele dizia representar um papel: "um papel que deveria conduzir não só à minha destruição (o que pouco importava) mas também à ruína de todos aqueles com quem eu já tivesse entrado em contacto" (p. 57).

No devaneio da internação, o protagonista produzia para si mesmo um ilusório roteiro policial. Todos estariam conspirando para levá-lo a um suposto tribunal, cujo veredicto de antemão decretava sua pena fatal. Nessa condição, Beers descreveu a astúcia da loucura, que 
mimetizava a razão e revelava uma coerência somente reconhecida por aqueles que compartilhavam sua anormalidade.

Quando a verdade se impôs, Beers acreditou ter tomado posse de seu self-control. O livramento foi relatado como um segundo nascimento: "para mim, pelo menos, o meu espírito parecia ter-se encontrado a si mesmo" (p. 126). No entanto, apesar de nunca mais imaginar o inquérito policial, ele não se sentia livre da moléstia, pois ainda falava demais e contraíra uma irrefreável vontade de escrever.

De posse da verdade e da compulsão pela escrita, o protagonista passou a usar o próprio sofrimento para denunciar o sistema de internação psiquiátrico de seu tempo. Tornouse uma espécie de correspondente de guerra. Mesmo sob as sovas dos enfermeiros, atado à camisa de força ou entubado para ingerir medicamentos, o autobiografado relatava os erros e os abusos de seus cuidadores.

Aprisionados, submetidos à vontade dos enfermeiros, trancafiados em "uma das maiores sociedades secretas do mundo" (p. 107), contidos na energia de suas loucuras, fadados a "viver ao abandono e morrer ao desamparo" (p. 79), tratados desumanamente, violados em sua privacidade, Beers e seus colegas sofreram nos hospícios em que foram confinados.

Apesar de tudo, convencido de sua verdade, Beers encarou sua missão: "meu único objetivo era viver bastante para recuperar a minha liberdade e denunciar os abusos praticados aqui e em outros estabelecimentos" (p. 173). A loucura do higienista não foi tomada por ele simplesmente como uma forma de desrazão, mas utilizada como maneira de se buscar a verdade.

Mais do que se livrar de um tratamento indigno, Beers ambicionava salvar todos aqueles que experimentavam a loucura, em seu tempo e no futuro. Para tanto, além do campo de batalha do hospício, ele tomava posição no front cerebral.

Considerando que seu cérebro funcionava como o dos demais alienados e descrevendo-o como "um mecanismo demasiado complexo" (p. 132), o biografado analisava sua própria capacidade de guardar memórias. O roteiro de suas fantasias e o engenho de suas manias eram tidos como manifestações próprias de um órgão em desarranjo e carente de uma razão soberana, modos de funcionamento compartilhados entre ele e os demais alienados.

Tão convencido da materialidade do funcionamento orgânico de seu cérebro, Beers chega a sentir concretamente sua razão quando ilustra as sensações no princípio do cativeiro e na posterior redenção da loucura. 
Já descrevi a sensação peculiar que me assaltou em junho de 1900, quando perdi a razão. Naquela ocasião o meu cérebro parecia espetado por um milhão de agulhas aquecidas a branco. Neste 30 de agosto de 1902, logo depois de haver recobrado em grande parte a razão, tive outra sensação bem distinta no cérebro. Principiou embaixo da fronte e estendeu-se gradualmente até cobrir a superfície inteira. A agonia de uma Razão moribunda fôra um suplício. As sensações de minha Razão nascente eram uma delícia. Como se o hálito refrigerante de alguma deusa amorável da Sabedoria estivesse soprando brandamente sobre meu cérebro (p. 130).

O cérebro doente - apresentado como continente e, ao mesmo tempo, comandante das relações entre a intimidade e a exterioridade - era a analogia do hospício, ambos vistos como lugares em que a vontade fora suprimida, a verdade escamoteada e a violência se desdobrara em desumanidade. Por isso, quer no período sadio quer no confino psiquiátrico, todos os momentos foram descritos por Beers como uma espécie de autoverificação interna que se desdobraria em um projeto social de libertação, fosse do irracionalismo dos hospícios, fosse da mentira dos espíritos.

De alguma forma, o projeto do autor se concretizou. O movimento de higiene mental liderado por ele nos EUA em princípios do século XX - alastrou-se pelo mundo e deu azo a numerosas ações governamentais e civis em direção à desinstitucionalização manicomial. Desde o início do século, os higienistas mentais atuaram a fim de dissipar comportamentos que poderiam levar a internações por motivos psiquiátricos.

Poderíamos creditar o modo pelo qual Beers relatou seu próprio estado mental à sua ignorância. Poderíamos dizer que a ciência do cérebro já evoluiu bastante e que hoje sabemos que esse órgão não funciona tal como apresentado em sua biografia. Poderíamos ainda dizer que, no tempo de Beers, a psiquiatria estava por demais apegada à dicotomia razão/loucura. Entretanto, parece-nos que sua obra tem um potencial muito mais agudo do que pode parecer à primeira vista.

A situação é a de uma vida descrita como a luta de outro eu coabitando um mesmo espaço; um crânio em que o eu natural disputa contra um eu inatural e em que a razão, similar à loucura, triunfa diante da desrazão por meio da persistência da vontade e do selfcontrol. A partir desse cenário, acreditamos poder explicar boa parte do funcionamento da pedagogia moderna de raiz psi.

O cérebro, nesse sentido, seria visualizado como um órgão que, quando funcionando em condições normais, viabilizaria a produção de uma personalidade única e distinta cuja configuração resultaria da luta entre humanidade e animalidade - a primeira metaforizada pela razão/consciência e a segunda pelo instinto/impulso. No caso da biografia há pouco 
relatada, foi somente quando os instintos renderam-se à razão que Beers pôde se livrar das garras do sistema de internamento. Este fora descrito como um ambiente em que predominavam a violência, a irracionalidade dos agentes e o sentimento de vingança. A narrativa insinua que tais componentes instintivo-animais teriam despertado no biografado e em seus colegas de internação reações similares às atitudes de seus algozes.

Beers concluiu que a única maneira de livrar-se da violência do confino seria via imersão em sua própria individualidade. A insuportável pressão externa teria encurralado o desarrazoado e restringido suas opções a exercícios de escrita automonitorados, dirigidos de si para si, apontando para uma estratégia terrorista diante do sistema de internação. Nos momentos mais tensos, a escrita compulsiva, realizada por quaisquer meios, tornara-se para Beers um tênue fio de contato com algum locus cerebral em que o autor ainda divisava lapsos de sanidade.

Nessa reconstrução de sua autoimagem, Beers especulou a origem de sua propensão à insanidade. Atribuiu sua irracionalidade, entre outras razões, ao medo de que a neurastenia, causadora da morte de seu irmão, também o ceifasse. Armado dessa convicção, o protagonista foi capaz de domar a fraqueza de sua vontade com a certeza de ter racionalizado sobre a possível causa familiar para sua loucura.

Muito mais do que salvar a si mesmo, ele acreditou encontrar, a partir da explicação racional de suas atitudes, um caminho seguro para esclarecer a essência de toda loucura. Desse modo, assumiu a missão de libertar todos os loucos do cárcere que cada qual impingia a si mesmo enquanto mantivesse bloqueado o livre exercício de sua própria racionalidade. A certeza desse caminho redentor teria sido o sopro refrescante da razão em sua alma. A libertação de si e de todos adviria do reconhecimento de uma potencial animalidade, própria a todos os humanos. A partir dessa consciência, bastaria, na visão do higienista, constituir cidades, hospitais e escolas como ambientes cientificamente preparados para que os humanos se afastassem da animalidade e vivessem uma vida de moralidade.

A biografia de Beers relata um ato de força.

Diante de seus verdugos, do desespero da família e de seu descontrole, o interno buscou guarida dentro de seu próprio corpo e de lá posicionou sua vingança contra toda a violência que ameaçava arrebatar seu próprio futuro. No interior do corpo, um crânio que abrigava o local exato em que as armas da reação eram preparadas. 
Entre suas possíveis armas contra a opressão, Beers escolheu a razão para reagir à animalidade de seus próprios gestos. O mundo que ele abrigava em sua caixa craniana foi tornado uma casamata e, ao mesmo tempo, o receptáculo de um idílio; um sítio de proteção, mas também de libertação.

A liberdade ambicionada por Beers se estabeleceria, segundo ele, caso o restante da humanidade aceitasse o trinfo da razão refrescante em cada pessoa. Imediatamente, a utopia redentora desse racionalismo de Beers se desdobrou em conclamações à previdência. $\mathrm{O}$ higienismo, que já colonizava o poder médico desde meados do século XIX, encontrou campo fértil na mente tal como a perspectivou Beers.

A história da educação dedicada a estudar a primeira metade do século XX nos conta que a imediata incorporação do higienismo às práticas pedagógicas ocorreu, notadamente, no interior do movimento em prol da Escola Nova. Ela nos conta ainda sobre os programas, as campanhas e os serviços dedicados a aplicar procedimentos lastreados pela crença na promoção da sanidade mental a partir do reequilíbrio da organicidade cerebral, consoante à crença de Beers.

Sobejam análises históricas em que o escolanovismo ${ }^{1}$ foi tido como o abrigo preferencial para práticas voltadas à normalização, à modelização e à padronização dos comportamentos e, por extensão, das consciências dos alunos a elas submetidos. Em dita historiografia, destacam-se autores que carregam nas tintas do tecnicismo por eles atribuído à Escola Nova. Nos quadros ali produzidos, observamos crianças atadas a cadeiras em laboratórios, nos quais a experimentação alcança os mais sutis movimentos corpóreos. Complexos aparelhos pesam, cronometram e estimulam infantes cativos diante de operadores atentos e rigorosos que anotam cada detalhe da ação realizada por seus objetos de estudo.

Considerando somente a narrativa da libertação de Beers, fica difícil imaginar que o movimento de higiene mental criado por ele redundaria em um programa mundial voltado a examinar, exercitar e, consequentemente, discriminar boa parte dos escolares a partir de então.

No interior do cérebro, segundo a concepção de Beers, todos seriam iguais, pois portariam a mesma razão soberana. No mundo interior do crânio, todos os humanos compartilhariam potencialidades equivalentes e civilizariam sua sociabilidade. A despeito do igualitarismo que a cerebralização aventada por ele insinuava, a historiografia sobre a Escola

\footnotetext{
${ }^{1}$ Cientes de que o termo escolanovismo é um neologismo, optamos por usá-lo em razão da abundante recorrência de seu uso, tanto em nossas fontes quanto nas referências.
} 
Nova no Brasil nos permitiu entrever que, nos tempos da higiene mental, foram praticadas discriminações de todo tipo, tais como a inculcação de gestualidades domésticas nas mulheres e a militarização dos movimentos nos rapazes. Em ambos os casos, as grafias procediam à ortopedia de todos os músculos e os rendimentos eram alvo de classificação permanente.

Quando recuperou a posse de sua própria razão, Beers voltou ao contato social, reaproximou-se do mundo em que esteve separado pela loucura e ousou encarar autoridades estatais para garantir o espraiamento de seu intento redentor. No entanto, segundo boa parte da referida historiografia, o projeto higiênico, ao se expandir, teria eliminado práticas locais de ensino, condenado o aprendizado rural em nome da suposta superioridade do nacionalismo urbano-industrial, arrancado dos pais a responsabilidade pela educação dos filhos e alijado os mais velhos da ascendência sobre as crianças.

No jogo das promessas e implicações aí levantadas, poder-se-ia criar oposições diversas, todas elas conduzindo ao simples dilema: ou a utopia higienista desejada por Beers foi distorcida ou o idílio do refúgio cerebral continha em si um novo, racional e moderno enclausuramento.

Nesta pesquisa, não optamos por nenhuma das respostas que tal dilema oferece. Não nos ativemos nem a distorções, nem a coações; também não optamos pelo contrário das duas proposições. Fixamo-nos apenas naquilo que se pôde produzir quando se visualizou a vida em termos de utopias egressas de olhares dirigidos a corpos e almas.

O procedimento de visualizar, no escopo deste trabalho, aproxima-se do gesto realizado pelo fotógrafo. Ao produzir uma fotografia, ele escolhe as lentes adequadas à sua pretensão, posiciona intencionalmente o objeto a ser imageado, preocupa-se com o cenário, com o arranjo dos personagens, com a intensidade da luz e com o matiz das cores. Após o disparo do obturador, ocupa-se da revelação, obtendo maior ou menor sucesso diante das intenções e limitações. Em nosso caso, os instantâneos por nós flagrados deveriam restringirse a "registros expressionistas de alguns incidentes escolares" (AQUINO, 2007, p. 18).

Considerando a imanência do higienismo nas práticas escolares modernas, pesquisamos a lavra de autores dedicados a analisar a Escola Nova sob as lentes da psicologia e da pedagogia. Tal sondagem seria, em nossas reflexões, equivalente a vasculhar, no interior das práticas estabelecidas pelo escolanovismo, as visualizações que tal movimento instituiu aos corpos em que seus agentes atuaram.

Para tanto, foram perscrutados dois momentos da história educacional brasileira, distantes entre si 80 anos: as décadas de 1920-1940 e as de 1990-2010. No primeiro caso, analisou-se a coleção Bibliotheca de Educação, coleção publicada entre 1927 e 1941 sob a 
editoria de Lourenço Filho, reconhecido pensador escolanovista; no segundo caso, foram apreciados 56 artigos publicados em periódicos educacionais entre 1993 e 2013, cujas temáticas estiveram ligadas ao escopo da Escola Nova. Em ambas as séries discursivas, ativemo-nos ao modo como o campo pedagógico formulou enfoques para abordar os processos envolvidos na cognição e traçar apreciações quanto às condutas esperadas pelos alunos alvejados pelas práticas educacionais, notadamente quando estas se mostravam inspiradas em concepções que atribuíam à corporeidade o cruzamento de ações e reações conferidas à psique, à anatomia e à sociabilidade.

Na composição do texto que aqui se apresenta, os capítulos III e IV conformam parte de nosso objeto de pesquisa, discutindo cânones da visualização de corpos inseridos em práticas pedagógicas fundadas em alguns princípios constituintes da Escola Nova. Os capítulos II e V complementam a composição do objeto de pesquisa, uma vez que eles se atêm, especificamente, às teorizações que se criaram quando se produziram suposições acerca do funcionamento da anatomia corporal, ora para curá-la, ora para modificá-la.

Tais teorizações foram compiladas em dois campos, afastados um do outro por mais de 100 anos. No caso do capítulo II, tratou-se de preleções emitidas, entre 1841 e 1863, por médicos vinculados à Academia Imperial de Medicina; já o capítulo V foi constituído por uma coletânea de enunciados abrigados no campo da biomedicina contemporânea. A partir dessas duas práticas discursivas, vislumbramos que ambas teriam produzido focalizações que anexaram os olhares dos experts aos corpos manipulados, determinando suposições de funcionamento no momento mesmo em que interferiam neles, fosse para curá-los ou modificá-los. A essas focalizações, novamente, denominamos visualizações.

Apoiados em nosso instrumental teórico, problematizamos possíveis proveniências do acoplamento de práticas anatômicas e psicopedagógicas no despontar de uma utopia sumamente contemporânea, perceptível nos referidos enunciados credenciados à biociência atual - seria ela a utopia do homem aprimorável.

Aventamos, então, que a busca por uma corporeidade visualizada em termos de seu desenvolvimento progressivo, desde os tempos que remontam à medicina do século XIX, teria alimentado toda sorte de intervenções, tanto no ambiente social-urbano quanto no espaço entalhado pelas individualidades. Talvez a crença no suposto caráter aprimorável do corpo humano explicasse a ineficácia ou mesmo a falsidade do dilema aventado na análise da biografia de Beers. Talvez a higiene mental não tenha sido incorretamente aplicada. Mais ainda, talvez ela esteja até hoje vigorosa e produtiva. Talvez, enfim, a ortopedia atribuída ao 
escolanovismo também continue existindo, porém agora incorporada por cada indivíduo na demanda por seu próprio aprimoramento psicobiológico.

Caso tais hipóteses alcancem plausibilidade, mostraremos as razões da força contida no projeto liderado por Beers e seus companheiros higienistas. No mesmo golpe, entretanto, teremos asseverado que essa força somente poderia ter sido aplicada se, eventualmente, aqueles que delas desfrutassem incorporassem em si mesmos a crença de serem seres incompletos e vulneráveis, à espera de aconselhamentos dos personagens responsáveis por manter operante a utopia do homem aprimorável. 


\section{Mobilização dos equipamentos: perspectivas teórico-metodológicas}

No ano 2000, Jurandir Freire Costa participou do Congresso Brasileiro de Saúde Coletiva com uma conferência que bem poderia sintetizar a inspiração teórica para o presente trabalho. Na ocasião, o afamado psiquiatra e psicanalista teceu considerações em torno das atuais conexões entre saúde e subjetividade. Tomando sua clínica como campo experimental e abrigando a hipótese de que, nos tempos presentes, a saúde tem ocupado o cerne dos processos de subjetivação, Costa (2000, s/p) abordou o que chamou de "crenças que os sujeitos têm sobre si”, aí abarcando ideias e atitudes capazes de alterar estados mentais e, no limite, redundar em compulsões, adicções e depressões.

No decorrer de sua reflexão, ele asseverou que a saúde compareceria como elemento fulcral dos atuais processos subjetivos e supôs que as razões para tal presença poderia ser anunciada como efeito de um "ethos do individualismo desengajado" (s/p), condição tributária de dois movimentos próprios da sociedade contemporânea: o processo de desinstitucionalização e a consequente perda do sentimento da totalidade subjetiva.

A atual desinstitucionalização, segundo Costa (2000), dever-se-ia à mudança no formato de coletivos sociais como a família, a igreja e as entidades políticas. Ditas congregações, ao terem suas práticas modificadas, teriam perdido a tradicional função de doar aos indivíduos uma consciência de compartilhamento e, consequentemente, de identidade. Da mesma forma, com a progressiva perda de importância dessas instituições, teria refluído também o sentimento de totalidade expresso pelos enunciados que circulavam dentro delas. Os grandes projetos compartilhados, as utopias e as crenças transcendentais estariam gradativamente perdendo primazia diante dos discursos assumidos como seus pelos pacientes do Dr. Freire Costa.

Com base nessas reflexões, o eminente psiquiatra especulou que despontaria no presente um novo conjunto de certezas, cujo compartilhamento estaria em franca ascensão no que tange à composição da subjetividade. Trata-se, por um lado, de "uma radical desidealização do corpo como fonte de vida; por outro, de uma idealização desse corpo como fonte de satisfação" (COSTA, 2000).

A desidealização contemporânea do corpo estaria em operação, segundo o autor, no interior de práticas orientadas a ampliar as performances corpóreas. Pela via das biociências, tal ampliação traria à baila do convívio social as questões da longevidade, da extensão dos limites corpóreos, do aprimoramento das habilidades, do uso de próteses e potencializadores de movimentos, enfim, traria à arena pública um desejo ardente pela ultrapassagem dos 
limites do corpo. No mesmo sentido, a idealização do corpo como fonte de satisfação acrescentaria a tal ultrapassagem o apego de cada um dos indivíduos contemporâneos às suas próprias idiossincrasias fisiológicas.

Destarte, conforme Costa (2000), quando o corpo se tornou sede dos projetos de futuro, quando a corporeidade passou a espelhar as opções éticas, quando as relações sociais começaram a ser referenciadas por critérios biológicos, o homem contemporâneo teria se libertado do antigo aprisionamento anatômico e abrigado em si mesmo a esperança de ultrapassar aquilo que, até o século XX, acreditava-se ser produção da natureza. Nessa perspectiva, a saúde, para além de se opor à doença e à inabilidade, não seria mais o resultado alcançado pelos cidadãos responsáveis por seus próprios hábitos. Nos tempos de hoje, a boa saúde estaria sendo usada como veículo na busca pelo máximo aprimoramento individual.

Partindo da hipótese estabelecida por Freire Costa, desenvolvemos esta pesquisa com o intuito de sopesar as possíveis aproximações entre as práticas estabelecidas pela educação moderna e a utopia contemporânea do homem aprimorável. Tal utopia, a partir das análises de Lucien Sfez (1996), poderia ser encontrada nos discursos científicos adjacentes a projetos como os que pretenderam mapear a totalidade do genoma humano, forjar uma biosfera no deserto do Arizona ou ainda desenvolver processos de inteligência artificial. Analisando os enunciados proferidos pelos idealizadores desses projetos, Sfez (1996, p. 328) encontrou neles a "preocupação universalista, a busca da pureza, a firme crença na correspondência do espírito e do corpo (operar nos corpos é operar no espírito) e na possibilidade de empurrar os limites da condição humana".

As condições históricas para a emergência de tais programas, segundo nossa hipótese, foram garantidas pelas visualizações estabelecidas tanto pela medicina higienista quanto pelo ideário escolanovista. Para tornar tal hipótese plausível, realizamos um percurso histórico que se iniciou no século XIX, caminhou em direção à primeira metade do século XX e aportou nos procedimentos da biociência contemporânea.

O presente percurso investigativo, bem como as premissas que orientam seus desdobramentos, tiveram como ponto de partida a pesquisa apresentada em 2009 como requisito para a obtenção do título de mestre em educação (RITO, 2009).

Sempre incomodados com o acosso proveniente da presença de enunciados psi no ambiente escolar, voltamo-nos a temas que partiam do conceito de inclusão escolar e 
passavam pela psicologia educacional e pela psiquiatria, alcançando a historiografia de inspiração foucaultiana dedicada a problematizar as relações entre educação e governo das populações nas cidades modernas.

A supracitada dissertação foi defendida em março de 2009. Seu título: $O$ alunoproblema e o governo da alma: uma abordagem foucaultiana (RITO, 2009). Nela estava presente nossa inquietação quanto à força de verdade alcançada por enunciados psi no ambiente escolar. O substrato empírico para tal empreitada foi constituído por um conjunto de laudos psicopedagógicos confeccionados entre 2004 e 2008 em clínicas particulares paulistanas dedicadas a acolher o encaminhamento de estudantes com queixas de problemas numa escola, também particular e paulistana, situada em bairro abastado da capital.

Constataram-se, então, algumas evidências inquietantes. Primeiramente, o apanhado dos laudos fazia parte de um montante maior. Naquele universo, composto por dezenas de documentos, observamos que, em apenas um ano, tinham sido elaborados laudos para mais de $10 \%$ do total de alunos matriculados no Ensino Fundamental da dita escola. Esse primeiro dado nos fez considerar a presença de algo como uma avalanche discursiva (LIMA, 2005) referente ao que parte dos psicólogos e psicopedagogos atuantes na área chamaria de dificuldades escolares (CHABANNE, 2008; COLLARES, 1995; GARCIA; JESUS, 2004; MACHADO, 1996; PATTO, 1999; PROENÇA; ROCHA, 2000).

Reparamos que o tom dos referidos laudos repetia um itinerário que há muito se encontra na discursividade psicológica dirigida à educação. Inexoravelmente, todos eles relatavam resultados de testes aplicados para sondar funções neuropsicológicas, tais como a atenção, a linguagem, os ritmos, a memória e a capacidade de construção visual, entre outras, sempre em busca de uma localização cerebral ou de uma causa neuronal para os supostos déficits.

Apontava-se, ainda, algo desconcertante: na quase totalidade das avaliações, o desempenho dos examinados apresentava-se sempre acima dos parâmetros estabelecidos pelas sondagens neurológicas. Entretanto, mesmo com as referidas funções neurais em normalidade diante dos exames, todos os indivíduos testados recebiam indicações para tratamentos psicopedagógicos. Isso porque, na imensa maioria dos casos, apesar de os exames comprovarem fisiologia cerebral preservada, os avaliadores impreterivelmente constatavam comprometimento nas respostas relacionadas à autoestima, à maturidade e à vontade.

Todas as características avaliadas eram tidas pelos examinadores como pré-condições para o bom rendimento escolar. Tais características permitiriam, segundo eles, aferir os graus de desempenho de cada uma das funções examinadas, assim como o posicionamento dos 
avaliados diante das expectativas daqueles que observavam suas condutas. Ademais, tanto os resultados tabulados quanto as sugestões dos psicopedagogos eram relatados em um documento denominado devolutiva. Esta recebia chancela das associações ou clínicas oficiais ${ }^{2}$ em que se realizara a investigação.

Ao problematizarmos as raízes em que se assentava a força de verdade alcançada por esse tipo de enunciado, sugerimos que a objetividade científica dispararia procedimentos de modelização que garantiriam o caráter preventivo e terapêutico dos aconselhamentos estabelecidos. Tal cientificidade estaria assegurada pelos dados estatísticos, cujas referências sempre estiveram relacionadas à média esperada para a idade. Daí as alegações sobre a normalidade virem acompanhadas por números, tabelas e gráficos, incluindo ilustrações com mapas que descreviam o funcionamento do cérebro e, ao mesmo tempo, apresentavam as supostas localizações das funções neurológicas.

Nas conclusões constantes em tais devolutivas, os aconselhamentos dirigiam-se à escola e à família. Quanto à primeira, apresentavam recomendações acerca de assuntos bastante corriqueiros, tais como o número de alunos em sala de aula, a personalidade do professor, o sistema avaliativo, as opções didáticas mais adequadas etc. No caso da segunda, aconselhava-se a respeito dos ritmos e tempos da casa, do trato com as dificuldades e do exercício da autoridade, sempre almejando a preservação da autoestima positiva do infante.

Acerca das terapias, como já dito, elas eram indicadas aos avaliados mesmo quando não se verificavam alterações nos resultados dos exames. Propunham-se acompanhantes, psicanalistas e, sobretudo, terapia comportamental-cognitiva, além do recorrente expediente à medicação psicotrópica. Em todos os momentos do percurso avaliativo, era constante a busca pela adesão e concordância do examinado, em relação tanto aos procedimentos quanto aos encaminhamentos.

Atentos a essas práticas - que entrelaçavam objetividade, prevenção e terapêutica - e atravessados pelas conceituações foucaultianas acerca da performatividade dos discursos, alegamos na ocasião que em tais laudos jaziam elementos dos pregressos princípios higienistas, emergentes no Brasil no século XIX. Para sustentar o argumento, foram vasculhados os substratos históricos do higienismo nacional, os quais nos possibilitaram afirmar que o movimento denominado higiene mental havia sido crucial para a expansão dos processos avaliativos dirigidos ao alunado brasileiro.

\footnotetext{
${ }^{2}$ Das associações encontradas, destaca-se o grande número de devolutivas chanceladas pela Associação Brasileira de Dislexia (ABD).
} 
Foi no interior do sobredito movimento que emergiu o termo criança-problema, tal como o anunciou Arthur Ramos (1939). Constatamos aí a íntima relação entre as práticas preventivas ditadas pela nascente psicologia escolar e o estabelecimento de ações de governamentalidade (FOUCAULT, 2008b) irradiadas pelo Estado brasileiro desde meados do século XIX (MACHADO et al., 1978), e passamos a atentar, então, para os efeitos do amplo processo de normalização escolar realizado no Brasil a partir das décadas de 1920 e 1930, sob a batuta da higiene.

Nesse percurso, colocamos em diálogo elementos de tal higienismo com os relatos das pesquisas de Nikolas Rose $(2003$, 2013) acerca dos enunciados alocados na biociência contemporânea. Vimo-nos, como resultado, diante de processos de subjetivação cujas práticas mantinham a tríade cientificismo/prevenção/terapêutica.

Ademais, tendo em vista que autores alinhados ao pós-estruturalismo utilizavam o termo bioidentidade (RABINOW, 2002; ROSE, 2013; ORTEGA, 2005, 2008; LIMA, 2005) quando analisavam os efeitos da incorporação de acepções psicobiológicas na constituição de subjetividades, passamos a especular que a referida força de verdade dos laudos psicopedagógicos encontrava uma explicação plausível na ideia de bioidentidade.

Finalizamos aquela pesquisa supondo que a veridicção conquistada pelos enunciados psi presentes no interior da escola moderna seria sobremaneira intensificada no ponto em que se aplicava tal força de verdade: no aluno. Este, incorporando a discursividade psicopedagógica, passaria a narrar a si mesmo por meio de uma identificação biológica autoimpingida. Por fim, chegamos a presumir que o aluno psicologicamente formulado figurava sua própria interioridade alinhando-a a determinado grupo psicossomático e, nesse processo, dispondo sua conduta à sanha nominalista do expert que o definia.

Desde então, aprofundamo-nos na leitura da obra de Michel Foucault, particularmente nos últimos cursos ministrados pelo autor francês no Collège de France, momento em que ele constituiu como objeto de suas pesquisas as relações entre subjetivação e veridicção presentes na história na cultura ocidental desde os gregos (FOUCAULT, 2010a, 2010b, 2011).

Ao estabelecermos um confronto entre o sobredito conceito de bioidentidade com as premissas foucaultianas relativas às relações sujeito/verdade na cultura ocidental, passamos a considerar a possibilidade de pensar a vivência na escola moderna nos termos em que o pensador francês denominou foco de experiência. Este abrigaria "formas de um saber possível, matrizes normativas de comportamentos, modos de existência para sujeitos possíveis" (FOUCAULT, 2010b, p. 5) e, por conseguinte, permitiria que, no interior dos limites estabelecidos pela experiência de seu tempo, cada indivíduo formulasse suas crenças, 
condutas e narrativas de si a partir - tal como no pregresso momento higienista - de verdades pronunciadas por analistas do comportamento humano, porém produzidas no encontro desses experts da conduta com a livre expressão das subjetividades. Encontro ocasional, aleatório, cravejado de arbitrariedade.

Na presente investigação, com o fito de revisitar as práticas instituídas pelos saberes higienistas e, por extensão, o fomento delas à livre subjetividade discente, retomamos discursos do - e sobre o - escolanovismo. Passamos, assim, a problematizar o momento escolanovista como locus privilegiado para situarmos a escolarização moderna na condição de campo de intercâmbio de saberes e normas, cuja operação implica existências imersas na forja de si como objeto científico. Ou seja, consideramos que, por meio de ações como exercícios planejados, tabulações de resultados, autoinspeção íntima, instigação à liberdade etc., poderia o aluno escolanovista tornar-se produtor de uma narrativa de si que fizesse de sua intimidade o cerne da longa história das objetivações, normalizações e terapêuticas psicobiológicas. Tais procedimentos trafegariam por caminhos similares aos dos projetos de redenção da humanidade por meio do aprimoramento psicobiológico de cada indivíduo.

Tendo esse intento em vista, apercebemo-nos da presença de outro elemento, aqui considerado de fundamental importância: a possível constituição, no contexto de implantação do escolanovismo, das condições históricas para o despontar da "concepção cerebralista de pessoa" (AZIZE, 2010/2011, p. 566). Tal noção, segundo o antropólogo brasileiro Rogério Lopes Azize, estaria em voga nos atuais discursos da neurociência. Conforme assevera o autor, na contemporaneidade, o cérebro teria tomado o lugar das pregressas concepções de alma e mente para referenciar aquilo que hoje se denominaria indivíduo. Desse modo, fenômenos subjetivos, cognição, conduta e liberdade seriam recodificados como ações pessoais compreensíveis a partir de processos visualizáveis em termos de moléculas, neurônios, sinapses etc.

Acompanhando as suposições de Azize, nossa pesquisa pretende engrossar a fila dos debates dedicados às relações entre educação moderna e biologização da subjetividade. Tal biologização, segundo nossa hipótese, abrigaria a crença de que a conduta pessoal seria modulada por epifenômenos de estruturas psicobiologicamente reconhecíveis. A Escola Nova, portanto, ao ancorar seus procedimentos nos processos psíquicos envolvidos na aprendizagem, compareceria em nossas análises como instância sócio-histórica em que se consolidaram práticas dirigidas a uma interioridade que passou a ser, progressivamente, codificada por uma linguagem científica, preditiva e, por conseguinte, terapêutica. 
Sustentamos, nesse sentido, que a contemporânea conquista do corpo por discursos cerebralistas não teria alcançado proeminência caso não tivessem os psicopedagogos escolanovistas formulado leis que atrelavam os processos cognitivos a ações previsíveis e transformáveis, segundo critérios estabelecidos na progressiva transformação do corpo humano em objeto da ciência psicobiológica.

Destarte, o termo psicopedagogia adquiriu nesta pesquisa um conteúdo mais amplo do que aquele que o restringe a uma disciplina constituída no século XX e dedicada a minimizar dificuldades de aprendizagem (GARCIA, 2004; CHABANNE, 2008). Aqui serão considerados psicopedagógicos todos os enunciados dedicados a estabelecer algum tipo de relação entre aprendizado e mecanismos cerebrais. Segundo nossas concepções, a emergência de tal relação teria afinidade estreita com a concepção de vida presente na narrativa de Clifford Whittingham Beers, que acreditava que sua humanidade seria forjada no embate dele consigo mesmo no espaço de sua própria interioridade. Assim sendo, tal recinto interior adquiriu, na lógica do nascente higienismo mental, uma materialidade e uma organicidade que o teriam disposto à ação externa pela via ora do exercício individual sobre a vontade, ora da intervenção científica, ou seja, por conduções psicológicas e médicas, concomitantemente.

Nesse sentido, acompanhamos o pesquisador português Jorge Ramos do Ó, para quem a emergência da pedagogia moderna somente poderia ter despontado em razão da incorporação dos referenciais psi pelo campo da pedagogia. Logo, na presente pesquisa, toda a pedagogia moderna foi considerada, em algum nível, um empreendimento psicopedagógico.

Ramos do Ó (2009), ao localizar em 1880 aquilo que ele anuncia como emergência do pensamento psicopedagógico moderno, justifica tal entendimento considerando que os procedimentos da pedagogia moderna operaram por meio de uma dupla captura: da necessidade de inspeção constante dos educandos e do estabelecimento de processos discursivos dirigidos às suas identidades. Conduta e cultura de si teriam se constituído, pois, no "problema pedagógico maior para as autoridades", assim como na "ocupação mais importante a desenvolver por cada aluno" (p. 13).

Dividindo a referida captura em dois tempos - o momento Compayré, entre 1879 e 1911, e o momento da pedagogia experimental, em vigor após a Primeira Guerra Mundial -, Ramos do Ó (2009) caracterizou o primeiro como um período de conquista da alma estudantil pela racionalidade da psicologia aplicada, cujo foco faria o agente escolar ocupar-se da moralidade de seus pupilos. Já no momento da pedagogia experimental, o foco teria se dirigido aos "mecanismos de adaptação, de acomodação, num jogo permanente de assimilação do real ao $e u^{\prime \prime}$ (p. 40, grifo do autor). 
Com base nisso, asseveramos que a pedagogia escolanovista, contemporânea ao espraiamento da higiene mental, ao absorver cânones discursivos da psicologia experimental e acrescentar a eles a reflexividade própria das encenações psicanalíticas, teria oferecido ao discente a possibilidade de encontrar a si mesmo no interior dos dizeres dirigidos à sua condição natural de aprendiz. De um lado, o experimentalismo, com forte inspiração iluminista, permitiria visualizar o cérebro como centro das reações orgânicas do corpo humano diante das convocações evocadas pelo meio social (FOUCAULT, 2002). De outro, referenciais psicanalíticos acrescentariam a essa visualização encenações produzidas pelo indivíduo na confecção de sua própria história.

Coerente com os ideais higienistas presentes na supracitada narrativa de Beers, a Escola Nova abrigou a tríade conscientização individual/racionalização/prevenção como fundamento para suas propostas de transformação geral da sociedade. Tal perspectiva talvez explicasse a autoria do prefácio da biografia de Beers.

A tarefa coube a Afrânio Peixoto, médico legista, político, professor, crítico, ensaísta, romancista, historiador literário, promotor entre os mais destacados das reformas educacionais que instituíram o movimento pela Escola Nova no Brasil. Ao apresentar a autobiografia de Beers, Peixoto (1934, p. 9) comparou sua história às agruras vivenciadas por Dante no inferno e por Dostoiewski na Sibéria, reputando-a como "uma situação singular, e excepcional, na literatura universal". Segundo ele, tratar-se-ia do exemplo de uma aventura pessoal que resultou em um movimento coletivo para "impedir que outras criaturas humanas se sentissem infelizes" (p. 11).

O altruísmo cientificamente escorado e as iniciativas de redenção da sociedade, supomos, teriam justificado a propagação mundial da higiene mental. No caso brasileiro, em 1923 foi fundada a Liga Brasileira de Higiene Mental. Entre suas ações, incluíram-se a criação de instituições ligadas à implantação de laboratórios de psicologia aplicada e clínicas de psiquiatria; o fomento a testes psicológicos em escolas públicas e fábricas; a implantação de consultórios de psicanálise nas escolas; a promoção de semanas antialcoolismo; o aconselhamento às políticas imigratórias; a seleção profissional; as políticas de esterilização e os exames pré-natais (REIS, 2000).

Nessa perspectiva, a redenção da humanidade passaria pela preocupação com a saúde mental de cada um dos indivíduos. Explica-se desse modo por que, desde o século XIX, a pedagogia moderna teria demandado dos sistemas escolares o aparelhamento psíquico do indivíduo para a vida adulta (Ó, 2009), etapa da vida que estaria marcada pela força da razão adulta sobre a imaturidade juvenil. Assim, no interior de tal discurso, o aprendiz seria 
convocado a visualizar a si mesmo como um ente instável, maleável e influenciável, estando portanto exposto aos ataques da desrazão.

Esse ser vulnerável, todavia, poderia equipar-se para a sobrevivência e para o convívio produtivo. Para tanto, bastaria que, dentro de sua equipagem, estivesse preocupado em desenvolver uma vontade soberana, livre e autorregulada que absorvesse a racionalidade própria do adulto e ativasse a vontade inerente à sua organicidade natural.

Considerando, com Foucault (2002, p. 142), a psicanálise como uma prática em que a "primeira tarefa da terapêutica será, através da interpretação dos sonhos e dos sintomas, modificar essa modalidade do sentido", encontramos nos higienistas mentais, desde Clifford Beers, produtores de sentido para que os infantes conquistassem o controle sobre suas vontades.

A orientação de sentido atrelaria possíveis condutas problemáticas a um conjunto de conceitos previamente determinados, cujas definições apontariam a um sujeito a priori reconhecível e a priori contido em sua própria estrutura psíquica. Ou ainda: armado de um conjunto de conceitos previamente estabelecidos, o diagnosticador, fosse psicólogo ou pedagogo, apropriar-se-ia da fala do analisado e comporia um novo conjunto de significados para atitudes que revelariam o caráter, concomitantemente, individual e coletivo das ações e propensões do educando. Em outras palavras, a verdade do analisado seria produzida por ele mesmo a partir de cânones estabelecidos por seu analista.

Além da diagnose como instalação de um novo sentido, a pedagogia psicanaliticamente fundamentada também continha um potencial condutivo, pois, como assevera Foucault (2002, p. 142), "o segundo tema da terapêutica será, portanto, a redescoberta dos conteúdos inatuais e das significações passadas da conduta presente". Nesse caso, o aluno passível de condução pela expertise psi seria levado a buscar em sua história de vida determinados episódios em que despontaria a verdadeira origem de seu comportamento inadequado. Assim, poder-se-ia ressignificar a motivação para atitudes tidas como insuportáveis pelo ambiente escolar.

Tal ação se realizaria por meio da vinculação do presente a um tempo anterior em relação à primeira manifestação do episódio problemático. A prospecção do passado, segundo Foucault, somente poderia ser realizada pelo analista, pois ele conheceria exatamente as chaves para penetrar a interioridade remota do analisado e, ao fazê-lo, permitir que o sujeito realinhasse sua conduta rumo a ações minimamente toleráveis em seu meio social.

Além das duas funções evocadas - ressignificação e composição de história -, a psicanálise também poderia viabilizar a indução como possibilidade aberta de intervenção psi 
no comportamento. Tal opção residiria na específica forma de tratamento da psique propalada pelos seguidores de Freud. Nas críticas foucaultianas, assim se "erige todo um conjunto de mecanismos de defesa que a cura psicanalítica tem o encargo de girar reatualizando as significações do passado pela transferência e pela ab-reação" (FOUCAULT, 2002, p. 143).

Nesse sentido se justifica a incorporação da psicanálise à educação realizada pelos higienistas, pois, em nome da reatualização dos significados, emergiria o caráter preventivo da educação, na medida em que o educador interferiria naquilo que, em sua opinião, interporse-ia entre o ensino, a aprendizagem e o convívio. A ação garantiria a construção de um conjunto de estímulos educativos voltados, concomitantemente, para as especificidades individuais e para os resultados esperados em cada fase do desenvolvimento da subjetividade, segundo as diferentes idades.

O educador psicanaliticamente orientado, então - após criar um sentido inconsciente para o comportamento inadequado, ressignificar seu teor reatualizando os conteúdos passados e, por conseguinte, estabelecer uma relação de transferência com o infante a fim de desbloquear os entraves à continuidade do desenvolvimento de sua subjetividade -, poderia auxiliar seus pupilos na livre e individual busca pela afirmação de sua autonomia, garantindo a superação da inadequação presente nos comportamentos tidos como insuportáveis para a rotina escolar.

Destarte, a higiene mental, teria reafirmado a infância como o objeto privilegiado da intervenção psicológica, fosse localizando nesse momento da vida a época preferencial para se mapear a hereditariedade, fosse considerando tal faixa etária como estágio-chave na formação da personalidade, fosse ainda vislumbrando no infante um mirante para generalizar teorizações que atrelassem condicionantes sociais à formação da individualidade. Nesse campo discursivo, a infância alcança o estatuto de objeto de estudo privilegiado e, por extensão, de esperança na redenção da totalidade social.

Apoiados nessas conjecturas, consideramos que o escolanovismo brasileiro expressa, tal como aventou Jorge Ramos do Ó (2009), o braço externo da psicopedagogia de base experimental que teria despontado, tanto no Brasil quanto em Portugal, no movimento de arranque do projeto sociopolítico voltado à massificação da escola. Ainda segundo o autor, a pedagogia moderna poderia ser considerada o campo da "construção racional dos fatos da intimidade, tendo como objectivo o estabelecimento do mapa da alma humana" (p. 39). Logo, "a alma seria portanto o produto diferenciado que a razão de Estado encomendaria à pedagogia psi” (p. 40). No caso brasileiro, especulamos que esse mapeamento da alma foi pedra de toque no momento em que a escola adquiriu ares públicos. 
A escola pública no Brasil - fomentada pela nova razão de Estado em vigor a partir do processo de industrialização desencadeado no entre-guerras - começou a se tornar um problema na década de 1920. Fosse no sentido de racionalizar a educação nacional por meio da preocupação com "rendimento, eficiência, produtividade, objetividade, previsibilidade, medição estatística, controle" (MATE, 2002, p. 22); no de "transformar as normas tradicionais da organização escolar" (LOURENÇO FILHO, 1963, p. 15); no da "prevenção das doenças mentais e o ajustamento da personalidade humana" (RAMOS, 1939, p. XX); ou ainda no "requisito do desenvolvimento nacional" (PATTO, 1984, p. 56), é incontestável que, a partir de 1920, cresceu visivelmente o número de instituições estatais, publicações analíticas, dados estatísticos e lideranças políticas, todos conjugados no sentido de realizar planos para a constituição de uma educação nacional.

Em nossa hipótese, no interior desses campos de enunciação constituíram-se discursos performativos de subjetividades propriamente escolares. Consideramos tais discursos como práticas criadoras de "efeito, efeito conhecido de antemão, regulado de antemão, efeito codificado que é precisamente aquilo em que consiste o caráter performativo do enunciado" (FOUCAULT, 2010b, p. 60).

Para tanto, a presente pesquisa pretendeu imergir no tempo em que os enunciados voltados aos infantes circularam entre estabelecimentos de ensino, consultórios, laboratórios, gabinetes e universidades com o fito de compreender e intervir no rendimento, no comportamento e na autoimagem dos educandos sob avaliação/definição/cuidado, sempre na perspectiva de compreender os critérios para a conexão dos comportamentos à individualidade e aos seus condicionantes psicobiológicos. Consideramos tal conexão crucial para analisarmos os mecanismos de veridicção acerca do próprio corpo assumidos pelo alunado no processo de constituição da escola moderna brasileira.

Destarte, o foco agora está dirigido ao conjunto de especulações biológicas psicológicas e pedagógicas que se produziram no bojo das proposições reformistas. Ao fazêlo, entendemos o aluno moderno como um "artefato social" (Ó, 2009, p. 26) produzido no interior de práticas discursivas que, historicamente, vincularam saúde, anatomia, prevenção e educação a uma sequência de definições e exercícios orientados para constituir o jogo entre subjetivação e veridicção próprio da governamentalidade moderna (FOUCAULT, 2008b).

Para sustentar tal intento, aproximamo-nos da compreensão de que "estabelecer os processos de criação e circulação dos textos é, literalmente, estar a fazer história. A verdade de uma fonte documental encontra-se, portanto, nos objectivos para que foi escrita e nas modalidades em que se viu transaccionada" (Ó, 2009, p. 26). 
Nesse sentido, Ramos do Ó (2009) assevera que a ciência da aprendizagem também foi construída sob as categorias e divisões definidas pelas ciências humanas - particularmente, as ciências da alma - e absorvidas pelos sistemas de ensino estatais. Segundo ele, "toda a relação educativa moderna tem uma raiz psi, o que significa dizer que passou a estar dependente dos diagnósticos, orientações teóricas, divisões e formas de explicação que a psicologia concebeu para indexar e reelaborar os imperativos éticos" (p. 25) que regulam os diferentes campos de intervenção pedagógica.

Ao lado do referido autor, consideramos que investigar a Escola Nova é também perscrutar as marcas entalhadas nos corpos discentes por artifícios psicopedagógicos modernos. Estes partem da crença no humano - perpetrando-a - como portador de uma interioridade em que se assentaria a individualidade na condição de uma especificidade original e coletiva, na medida em que só se tornaria visível quando lastreada por dados aferidos nas infinitas comparações com histórias de vida análogas, seja por referentes etários, morais, fisiológicos, hereditários ou vocacionais.

Fossem esses dados aferidos a partir de conceituações psicanalíticas, psiquiátricas, eugênicas ou psicológicas, entre tantas, sempre se tratou de constituir um campo racionalcientífico no interior do qual as idiossincrasias, os acidentes e os desvios serviriam como elementos para reorganizar as próprias teorizações. Nesse processo, conforme especulamos, produziram-se elementos que nunca mais deixaram de preocupar os cidadãos modernos: a saúde, o equilíbrio, a inteligência, a vontade, o desenvolvimento, a eficiência, a moralidade etc. Todos esses caracteres teriam sido produzidos na lida escolar e estabelecidos para o conjunto da sociedade como componentes de uma utópica visão acerca da natureza humana.

Apoiados nessas considerações, pretendemos sopesar o papel protagonista da escola moderna em um aspecto particular: a anatomização da alma. Para tanto, vasculhamos uma série discursiva de intensa circulação no processo de instalação do escolanovismo brasileiro para prospectar elementos que nos levassem a supor alguma relação da escola moderna com os cânones dos processos contemporâneos de individuação.

Desse modo, entendemos que a incorporação das alocuções psicopedagógicas pelos alunos possibilitou-lhes constituir uma identidade psicofísica a partir da discursividade pedagógico-científica que, por décadas, fez dos escolares o objeto de seu estudo e o alvo de sua intervenção. A identificação dos alunos escolanovistas com seus próprios corpos e suas próprias almas teria viabilizado o estabelecimento de estratégias progressivamente individualizadas, tendo em vista instigar cada um deles a se autoexaminar segundo os aspectos definidos pelos profissionais dedicados a analisar suas condutas. Nos tempos da 
Escola Nova, fossem relacionadas a comportamentos sexuais, a focos atencionais ou a opções morais, todas as escolhas dos estudantes modernos passaram a ser associadas a ações pessoais livremente decididas, pois, no interior dessa lógica discursiva, seriam livres as expressões de sua interioridade (Ó, 2003).

De acordo com Ramos do Ó, ao se racionalizar a psique infantil - examinando as condutas dos educandos e instigando-os à livre expressão -, teria sido possível à pedagogia moderna/psi estabelecer critérios para que mente e corpo estivessem em consonância com a vontade, no sentido de viabilizar desenvolvimentos tidos como harmônicos. Assim, quando a pedagogia acolheu como sua a tarefa de garantir a harmonia psicofísica dos escolares, ela disparou um conjunto de práticas cujo núcleo incluía a adesão de cada estudante à normalidade cientificamente instituída e, por conseguinte, à constante e livre autoverificação individual.

Inspirados nesses critérios passamos a nos referir à psicopedagogia moderna (Ó, 2009) como o movimento educacional, emergente no Brasil após a Primeira Guerra Mundial, que se dedicou a produzir suposições para o funcionamento mental a partir da observação dos comportamentos. Em outras palavras, quando o cérebro passou a ser visualizado como um órgão e, portanto, como uma estrutura passível de codificação em termos do saber anatômico, a captura da conduta discente pela discursividade psicopedagógica pôde escorar aquilo que doravante se consideraria educação científica.

Nesse sentido, adotamos como premissa que a escola moderna não foi produtora ou reprodutora de representações preconceituosas ou estereotipadas acerca do corpo dos estudantes; antes, ela foi artífice de um modo de visualização específico e produtivo. Assim, especulamos que a psicopedagogia, ao enfocar a vida cognitiva de seus estudantes, atuou decisivamente na produção de uma natureza que, disposta aos infantes, passou a inseri-los na própria natureza biológica do humano em geral. Em outras palavras, falamos em produção de realidade, e não em forja de irrealidades.

A biologização da vida foi, reconhecidamente, objeto de numerosos estudos de Foucault (1999b, 2001b, 2004b, 2006, 2008a, 2008b). No entanto, a análise do saber biológico como componente de uma subjetividade reflexiva e responsável, parece-nos, foi mais detidamente desenvolvida por Nikolas Rose (2001, 2003, 2013).

Focalizamos como tema geral de nossa tese, pois, o presumido jogo entre saberes psicobiológicos e o consequente incitamento a narrativas de si, em que a individualidade seria constituída como entidade, ao mesmo tempo, biologicamente genérica e psicologicamente inusitada. Acompanhando as opções teóricas elencadas, estaremos empenhados em analisar os 
processos de subjetivação impetrados por discursos tidos como verdadeiros em variados momentos históricos, preocupando-nos, sobretudo, com os campos discursivos que se autooutorgaram a condição de emitentes de verdades acerca do aprendizado, da vida e da espécie humana.

Sob o ponto de vista metodológico, a fim de forjar uma análise que abdique da perspectiva representacional, aterraremo-nos aos trajetos percorridos pelos especialistas para chegar às suas definições, com atenção aos silenciamentos, aos consensos, às repetições e às disputas aí em jogo. Assim, trataremos as imagens emitidas pelos enunciados dirigidos aos corpos doentes, aprendizes ou viventes como experiências forjadas na fricção entre diferentes processos de veridicção e os corpos que a partir deles se forjaram.

Percorrendo a historiografia da educação, encontramos lautos estudos dedicados a analisar discursos dirigidos ao encontro entre ciência, subjetivação e terapêutica em termos de representações (RAGO, 1985; HERSCHMANN, 1996; LOBO, 1997; PATTO, 1999; MONARCHA, 1999, 2001a, 2001b; MATE, 2002; ROCHA, 2003; GONDRA, 2004; CARVALHO, 2006; D’AVILA, 2006). Mais adiante, aproximar-nos-emos desses trabalhos; por ora, basta-nos afirmar que todos eles - apesar da grande diversidade de fontes, objetos, temas e cronologias - problematizam o approach científico-biológico da infância sujeita à escolarização em termos de modificações do real, de modo que as imagens forjadas pela discursividade escolanovista estariam encobrindo interesses sociais, políticos ou ideológicos.

Tais autores, em sua quase totalidade, trataram o acosso médico dirigido à escola em termos de aplicação de um modelo de medicina baseado no positivismo, no interior do qual os educandos, assim como toda a sociedade, estariam confinados às imposições cientificistas que perpetuavam modos de vida próprios à ascendente burguesia branca e ocidental.

A fim de confrontarmos as perspectivas perpetuadoras do gesto investigativo amparado na representação, empreendemos um recorte bibliográfico acerca da história da medicina (CANGUILHEM, 2005, 2006b; FERREIRA, 1996; FOUCAULT, 2001b, 2003, 2004b, 2006, 2008a, 2008b; GONDRA, 2004; HERSCHMANN, 1996; MACHADO et al., 1978; PATTO, 1984; ROCHA, 2003; ROSE, 2013; SFEZ, 1996). Nesses autores encontramos argumentos para afirmar que normalidade, subjetivação e ciência foram elementos atuantes no discurso médico desde seu momento positivista, em meados do século XIX. Assim, passamos a trabalhar com a ideia de que as alocuções positivistas, muito além de aventadas distorções representacionais, atuavam estabelecendo referências para processos de subjetivação que, desde a tenra infância, levaram os indivíduos modernos a narrarem a si mesmos como entes psicobiológicos, cuja natureza incluía a condição de seres orgânicos, 
livres e portadores de verdades reveladas de si para si mesmos. Tendo em vista as teorizações de Foucault (2003, 2004b) acerca do poder médico, situamos no binômio expert/cliente um elemento-chave para a sustentação de uma noção de vida própria a ser vivida por todos aqueles que desejassem manter sua condição de humanos.

A medicina positivista do século XIX, em nosso entendimento, fez muito mais do que produzir uma ciência sobredeterminante. O século XIX criou uma noção de natureza humana que escorou e foi escorada por numerosas práticas sociais, entre as quais se poderia inserir as ações da expertise estabelecida pelos educadores. Aventamos então que não foi apenas a medicina positivista que se impôs e que se impõe à escola até hoje; foi também a escola moderna que consagrou uma maneira de visualizar a criança, o aprendiz, o jovem e o aluno como seres em desenvolvimento, cujas estruturas orgânica e psíquica poderiam ser cientificamente previstas e terapeuticamente resgatadas, desde que os educandos abrigassem em si mesmos os aconselhamentos daqueles que bem poderiam ser nomeados como experts da interioridade biopsíquica, ou seja: os psicopedagogos.

No que tange à busca pela saúde, existiria na cultura ocidental, desde pelo menos os epicuristas (FOUCAULT, 2010a), uma relação terapêutica estabelecida entre indivíduos doentes e especialistas. Embora, ao longo do tempo, fisiologia, saúde, sofrimento e corpo, entre outras, tenham sido palavras constantemente modificadas, não se pode negar que a eliminação de males, fossem físicos, fossem anímicos, dependeu de algum tipo de relação entre o portador do corpo e o produtor de verdades sobre seu funcionamento.

Pesquisando sobre os enunciados modernos dirigidos a tal relação, Foucault (2004b), em $O$ nascimento da clínica, sugeriu a emergência de um tipo específico de especialista no corpo humano: o anatomoclínico. Herdeiros da filosofia iluminista e presentes nos debates com os revolucionários franceses, os médicos oitocentistas europeus teriam vivenciado, segundo o autor, o surgimento de uma experiência bastante específica em termos de ação sobre o corpo.

Tal experiência teria sido apurada na época em que os Estados europeus rompiam suas amarras com as burocracias soberanas e adentravam o espaço do governo de massas populacionais em nome da sociedade civil. Nesse contexto, Foucault acompanhou o amálgama de três práticas que possibilitariam o surgimento da experiência médica positiva: a medicina nosológica, a anatomia e a medicina clínica.

Nos cinquenta anos que circundaram a passagem do século XVIII para o XIX, o autor francês mapeou os deslocamentos que a medicina nosológica - segundo ele, presente na Europa desde o século XVII - realizou em direção às práticas da clínica, até quando ambas 
encontraram os gestos dos anatomistas. Nesse trajeto, ter-se-ia instituído gradativamente uma medicina individual no interior da qual o olhar do especialista para o corpo morto constituiu uma nova perspectiva para a origem e o desenvolvimento tanto da saúde quanto da doença, fosse numa peça anatômica específica, fosse em toda a espécie em que ela estivesse inserida.

Sopesando os enunciados dos anatomistas, Foucault relatou o processo pelo qual o tato, a audição, o olfato e, fundamentalmente, o olhar médico diante de corpos tomados pela doença elaboravam uma gramática capaz de elevar as camadas de tecidos observadas à categoria de signos emitidos pelo mal. Estes, apreciados pela racionalidade anatômica, apresentariam a especificidade da reação individual diante da agressão provocada pela doença. A vitória da enfermidade possibilitava ao anatomista, segundo Foucault (2004b), estabelecer um mapa tanto do percurso convencional da doença em suspeição, quanto da reação individual do organismo afetado. Esse novo modo de enunciação das verdades acerca das vicissitudes individuais teria garantido "o lugar determinante da medicina na arquitetura de conjunto das ciências humanas" (p. 218).

A fim de desdobrar a importância do saber médico na cultura ocidental, recorremos novamente a Nikolas Rose (1997), atentando agora ao confronto estabelecido por ele entre as práticas alcunhadas por Foucault como liberais - entre elas, as dos anatomopatologistas - e outra formação discursiva, esta mais recente, emergente após a Segunda Guerra Mundial e nomeada pelo autor francês como neoliberalismo.

Com base nas asserções de Foucault (2008a) em sua obra Nascimento da biopolítica, Rose (1997) debruçou-se sobre a maneira como tais estilos de intelectualidade se relacionaram com a arte de governar em vigência nos respectivos contextos históricos. Sustentou ele que a regulação do Estado aconselhada pelos experts liberais - aqueles que Foucault aproximou dos médicos positivistas - teria induzido nos órgãos administrativos estratégias de transparência, de enumeração e de documentação mediante as quais deveriam ser consagrados os mecanismos do mercado, da sociedade civil e da cidadania.

O liberalismo, assim, teria estabelecido a ciência como campo discursivo em que se arraigaram os procedimentos que garantiram o bem-estar, a liberdade e a expansão das forças produtivas. Para tanto, tais cientistas deveriam sugerir novas relações entre o conhecimento e o Estado, pronunciando suas determinações a partir daquilo que consideravam ser $a$ sociedade. Esta seria formada por um conjunto de sujeitos ativos, autônomos e desejosos das benesses oferecidas pelos experts, os quais, por falarem em nome da própria sociedade, tornar-se-iam aliados dos cidadãos na busca por seus direitos à saúde, ao arbítrio e ao enriquecimento. 
Portanto, no seio do Estado ter-se-ia gestado uma crítica ao próprio funcionamento estatal, na medida em que se estabeleciam questões referentes a quem deveria governar, a partir de quais condições se exerceria a autoridade e o que a legitimaria. Fora do Estado, mas oficialmente reconhecidos por ele, atuariam os experts que, superando os métodos da soberania, viabilizariam o governo das populações por meio das demandas que cada cidadão pudesse reivindicar como direitos seus perante o Estado, então liberal.

No contexto de hegemonia do liberalismo, assim, os cientistas foram guindados ao pedestal da cultura. Seus conselhos positivos ganharam ares de políticas estatais, suas intervenções foram acolhidas e, por conseguinte, as reações a elas foram confinadas ou ao ostracismo ou à ilegalidade.

Em contraposição aos experts liberais, Rose (1997) analisou os experts neoliberais. Estes, atuantes, fundamentalmente, após a Segunda Guerra Mundial, não mais estariam vinculados diretamente ao Estado. Paralelamente às instituições estatais, os referidos intelectuais atuariam em campos da paramedicina, da previdência privada, dos grupos de assistência etc., reivindicando teorizações e procedimentos terapêuticos especificamente identificados com as individualidades que a eles recorressem.

Entre a subjetividade instada pelo modelo positivista-liberal e o contemporâneo insuflar das bioidentidades, podemos situar os educadores escolanovistas, os quais teriam, segundo nossa hipótese, garantido a adequação das determinações positivistas à busca neoliberal pelo autoaprimoramento biológico.

Situamo-nos, assim, muito longe das análises que pretendem abordar a atual generalização da preocupação com a saúde como ação de um suposto poder assimétrico da medicina em relação aos demais campos de convívio social. Desejamos, ao contrário, tratar nossas fontes a partir do que elas dizem e não do que escondem, buscando compreender suas produções, muito mais do que suas faltas. Intencionamos observar as invenções como emergências, e não como meras arbitrariedades a obstaculizar possíveis ações emancipatórias.

Evidentemente, ocultamentos, omissões e, sobretudo, arbitrariedades estão presentes em quaisquer práticas discursivas. No entanto, nossa crítica dirige-se ao presente e pretende inquirir sobre aquilo que, hoje, alimenta poderes e mantém certos personagens sociais conduzindo a vida de outros.

No caso dos sobreditos discursos alusivos aos transtornos escolares (RITO, 2009), sugerimos que eles situam os portadores desses transtornos muito além da condição de vítimas. Longe de decretarem uma adesão alienada, tais discursos veiculam inclinações por determinada condição psiconeurológica. Esta deveria aderir ao vivido e passaria a constituir 
corpo, alma e conduta. Nesse sentido, a experiência de um portador de transtorno seria por ele vivenciada como parte de sua diferença e, ao mesmo tempo, como pertença a seu grupo biológico.

Sobrepor às verdades historicamente produzidas novas verdades que se imporiam em nome de supostas emancipação, libertação e esclarecimento aproximar-nos-ia de pensadores que Foucault (2010c) denominou burocratas da revolução.

Desse modo, distanciamo-nos da vertente interpretativa presente nas seguintes palavras de Ariès (2012, p. xxii):

Partimos necessariamente do que sabemos sobre o comportamento do homem de hoje, como de um modelo ao qual comparamos os dados do passado - com a condição de, a seguir, considerar o modelo novo, construído com o auxílio dos dados do passado, como uma segunda origem, e descer novamente até o presente, modificando a imagem ingênua que tínhamos no início.

Tal suposição seria correspondente, em nosso entendimento, a uma concepção de história que atribuiria ao historiador a função de revelar origens a partir das quais as diferentes práticas humanas teriam se ramificado. Nessa perspectiva, ao estudioso da história - mesmo quando ele assumisse sua imersão no presente - estaria assegurada a tarefa de reconhecer as diferentes representações de estruturas permanentes e universais, tais como organização social, família, religiosidade, criança, sujeito etc. Além disso, considerar a história em termos da sucessão de modelos prendê-la-ia a princípios etapistas e, no limite, demandaria dela lições para o presente.

Não comungamos com esse raciocínio, uma vez que ele parece manter, em algum nível, um estreito compromisso com uma história estruturalista, total, explicativa e esclarecedora. Ao nos valermos da ideia de visualização, estamos nos afastando daqueles autores que se atêm ao conceito de representação para auscultar um suposto imaginário constituído em dada época. Distanciamo-nos, portanto, do campo reconhecido como história das mentalidades, quando esta procura restaurar o quadro imagético em que se deram tais ou quais manifestações culturais. Não desejamos reconstruir épocas ou resgatar personalidades, tampouco descrever estruturas sociais ou biografias proeminentes.

Nossa noção de história diverge daquela enunciada por Philippe Ariés (2011, p. 277) ao apresentar o sistema de mentalidades de uma dada época como sendo "algo como um sistema ótico que modificava a imagem real". Tampouco procuramos, "a partir das palavras, explorar um campo semântico, isto, é o nicho onde se acha refugiado o conceito" (DUBY, 1990, p. 19). 
Destarte, afastamo-nos igualmente de autores como Roger Chartier (1991, p. 177), para quem os escritos seriam expressão das "representações contraditórias e em confronto, pelas quais os indivíduos e os grupos dão sentido ao mundo que é o deles". Não comungamos, tampouco, com a ideia de que a leitura contemplaria uma "operação de construção de sentido" (p. 178), tal como o autor a apresentou, pois essa concepção de sentido operaria por meio da distinção entre práticas sociais e "representações inscritas nos textos" (p. 179). Dita separação nos faria correr o risco de procurar, aquém ou além dos sentidos atribuídos pelos leitores, uma realidade supostamente deturpada pelas representações.

Para Foucault, a quem nos afiliamos, discursos são práticas e práticas estão imersas em jogos de verdade, de modo que tanto os emissores dos discursos quanto seus receptores estão situados em diferentes pontos da aplicação de poderes. Nessa perspectiva, o historiador seria capaz apenas de detectar instantâneos de combates que se perderam no tempo passado, mas que ainda respaldam lutas no presente. Daí aliarmo-nos a autores que asseveram "que nada existe em história, já que aí tudo depende de tudo, como veremos, o que quer dizer que as coisas só existem materialmente: existência sem rosto, ainda não objetivada" (VEYNE, 1982, p. 171). Dessa forma, muito além das origens, muito além dos começos ou mesmo das comparações com o presente, tratamos de estudar a "história do que os homens chamaram de verdades e de suas lutas em torno dessas verdades" (p. 172). Ambicionamos encontrar aquilo que foi tornado problema pelos homens do passado, atentando para o modo como esses problemas foram discutidos e, antes de tudo, como tais problematizações forjaram objetos que se instalaram em nossa cultura e que até hoje se mantêm como enunciados imprescindíveis.

Em nossas argumentações, nunca existirão a medicina, o humano, a criança, a ciência, senão "como objeto a não ser dentro de e mediante uma prática" (p. 169). Daí ensejarmos um texto histórico em que poder, biologização da vida, desenvolvimento psicobiológico e racionalização figurem sempre como elementos discursivos que justificam ações de uns modificando as ações de outros.

Nossas credenciais teóricas foram eleitas de modo a contemplar nosso desejo de adequar as perspectivas analíticas ao objeto de estudo escolhido. Portanto, fomos impelidos a abdicar da sobredita abordagem representacional e a ultrapassar a leitura foucaultiana quando ela se restringiu à análise dos jogos entre saberes e poderes.

Em relação à obra de Foucault, poderíamos aventar que ela, a partir das aulas congregadas em Do governo dos vivos (FOUCAULT, 2014), operou um acentuado deslocamento teórico-metodológico. Naquele curso, o autor explicitou que toda sua análise acerca da política tinha até então se estabelecido em razão de sua pretensão de ultrapassar as 
apreciações que tomavam como ideológicos os discursos que escoravam as relações de poder. Tal ultrapassagem foi justificada por ele a partir dos objetos sobre os quais ele doravante se debruçou. Fundamentalmente em relação aos cursos Em defesa da sociedade, Segurança, território, população e Nascimento da biopolítica, Foucault (2014) assumiu ter se dedicado a analisar os processos de governamentalidade instituídos no interior dos discursos tidos como liberais entre os séculos XVIII e XIX.

Asseverou ele que, perante o espraiamento das ações de governo - das mãos do soberano para diferentes instituições, tais como a escola, o quartel e a prisão (FOUCAULT, 1987) - alastraram-se pela sociedade, principalmente durante o século XIX, saberes que instavam os cidadãos ao autogoverno pela via da normalização (FOUCAULT, 2008b) e da libertação do homo aeconomicus (FOUCAULT, 2008a). Desse modo, devido aos objetos escolhidos, tratava-se de analisar a condução de condutas em termos do binômio saber-poder.

A partir do curso Do governo dos vivos (FOUCAULT, 2014), de 1979/1980, entretanto, ele deslocou seu objeto de pesquisa: da inserção dos indivíduos nas instituições para as relações dos indivíduos com a verdade que circulavam em suas respectivas culturas. Embora tais relações nunca tivessem desabitado o horizonte de suas análises, Foucault passou a fixar sua atenção na justaposição estabelecida entre o enunciador do saber e seu objeto. Supôs, então, que se poderia encontrar, desde há muito na cultura ocidental, práticas que implicavam a incorporação de verdades pelos indivíduos a elas expostos e delas enunciadores (FOUCAULT, 2010a, 2010b, 2011). No caso do Cristianismo, o jogo das verdades e dos processos de subjetivação teria pendido para relações de conversão (FOUCAULT, 2014).

Tal jogo obrigaria qualquer pretensão analítica a considerar como interdependente a dinâmica entre os modos de veridicção e de subjetivação em circulação numa dada cultura. Isso porque, segundo Foucault, uma verdade somente se performa caso seja capaz de modificar o sujeito ligado a ela. Além disso, o sujeito, no processo de sua modificação, também obrigaria o enunciador de verdades a constantemente redimensionar suas alocuções, de modo a garantir a voluntária e ativa incorporação de ambos à verdade estabelecida nos processos de veridicção.

Toda esta pesquisa foi inspirada em tal noção de verdade/veridicção. Em nossas reflexões, em se tratando de alocuções dirigidas aos corpos modernos, não seria possível nenhuma imposição assimétrica. Sejam os processos vitais alvejados pelos biocientistas, sejam as estruturas recortadas pelos anatomistas, as capacidades aventadas pelos psicopedagogos ou as alocuções dirigidas aos corpos dos indivíduos modernos, tais elementos 
tornam-se verossímeis somente quando recebidos e apropriados pelos próprios indivíduos a que se destinaram.

Tendo em vista as questões levantadas a partir das discussões sobre práticas de visualização do corpo biológico, abordamos algumas reflexões provocadas por esses empreendimentos para especular sobre dois aspectos: nossa metodologia de pesquisa e os efeitos subjetivadores ligados às referidas práticas.

No que tange ao primeiro aspecto, intencionamos perscrutar nossas fontes conforme o procedimento sugerido por Foucault: como vestígios arqueológicos (FOUCAULT, 2007). Cada um dos pequenos elementos encontrados nos campos enunciativos escolhidos foi analisado em sua materialidade própria, tendo sido sondadas suas especificidades internas, tanto em termos de sua produção quanto no que se refere ao processo de sua circulação. A seguir, tais elementos vestigiais foram inseridos em séries marcadas pela repetição ou aversão em relação a noções avizinhadas. O ponto de chegada dessa abordagem seria a confecção de um quadro no qual não estaria presente toda a história relativa ao objeto estudado, nem estaria descrito um acidente parcial e desprovido de sentido. O quadro a ser ora forjado deveria conter similitudes com elementos indissociáveis de nosso tempo, de nossa figuração subjetiva, da história de nosso presente.

Assumimos nosso texto como forja, portanto. Congregando os vestígios coletados, estabelecendo critérios de semelhanças e diferenças e organizando os fragmentos dispersos numa lógica própria à época em que apareceram, ansiamos por produzir uma imagem. Esta deveria servir para que cada qual dos sujeitos contemporâneos encontrasse nela projetado algum aspecto de si mesmo; uma imagem, portanto, que guardasse elos arqueogenealógicos com o homem moderno.

A visualização aqui pretendida é ação arbitrária, mas não falseadora, uma vez que não há verdade a ser escamoteada. Tal como faziam os médicos anatomistas, nosso percurso investigativo compõem-se da seleção dos dados a serem investigados, da busca por repetições e anomalias, da submissão à parcialidade das teorizações. Na presente pesquisa, todas essas ações prestam-se a criar um texto que produza figurações ao descrever o secular e moderno processo de imageamento do corpo do educando ocidental.

Destarte, dirigimos nossa análise para objetos emergentes das relações entre campos discursivos congregados naquilo que podemos estabelecer como práticas terapêuticoeducacionais. Operando desse modo, apoiamo-nos na hipótese de que a generalização sem conflito, sem oposição e sem contradição de modos de existência fundados na corporeidade psicobiológica estaria presente no universo escolar desde o estabelecimento da pedagogia 
moderna brasileira no século $\mathrm{XX}$, assim como na premissa de que tais modos teriam se espraiado pelo tecido social, convocando cada indivíduo a referenciar sua intimidade no interior de dada população, cujo gabarito de inteligibilidade partiria de uma noção específica de natureza humana. Em outras palavras, a aliança indelével entre educação e salubridade teria tornado a escola moderna um poderoso manancial de onde partiriam enunciados para a medicalização das subjetividades.

A fim de tangenciar o tema da subjetivação promovida pela enunciação medicalizante, analisamos dois campos discursivos responsáveis pela instalação de dois modos de visualização corpórea próprios do olhar médico sobre a vida. São eles: o imageamento do corpo oferecido pelas atuais biotecnologias e as pregressas práticas anatômicas oitocentistas de visualização do corpo doente. Assim, extraímos tanto da biociência contemporânea quanto da visualização oitocentista os cânones que teriam sedimentado a produção de imagens corporais que supomos escorarem as diferentes práticas discursivas na atualidade educacional.

Conscientes de que não há linearidade necessária nem causalidade direta entre os domínios referidos, pretendemos localizar, a partir deles, aquilo que Paul Veyne (2009) nomeou diferença última de momentos históricos nos quais se instituíram procedimentos que foram anexados a corpos, cujas existências nunca mais prescindiram das verdades estabelecidas pelas práticas discursivas que lhes doaram sentido; donde essas práticas estarem envolvidas pela máxima "fazer ver, dizendo o que se vê" (FOUCAULT, 2004b, p. 216).

Tal como Foucault (1995, p. 231), nossa ambição reside em “criar uma história dos diferentes modos pelos quais, em nossa cultura, os seres humanos se tornam sujeitos". Destarte, não vasculhamos conceitos universais acerca dos quais os enunciados dirigidos a sujeitos transcendentes constituiriam representações de algo que manifestaria ou esconderia aquilo que supostamente seria o real.

Cabe adiantar que optamos por utilizar o termo visualização em referência àquilo que realizam as técnicas de imageamento do corpo $^{3}$ (ORTEGA, 2008). Os aplicadores de tais técnicas reivindicam objetividade, mas, como veremos, na confecção da imagem propriamente dita, a forja dessa visualização limita-se às possibilidades técnicas oferecidas pelos aparelhos nela envolvidos. Nesse sentido, tal imageamento bem poderia ser tido como a produção de imagens a partir das condições disponíveis no momento mesmo em que elas são

\footnotetext{
${ }^{3}$ Entre essas técnicas, destacamos o PET-scan (Positron Emission Tomography), exame que produz imagens sobre fluxos corporais, tais como o sanguíneo, o metabólico e o gasoso.
} 
visualizadas. Deve-se ressaltar, entretanto, que essas condições não determinam as imagens; apenas oferecem a elas possibilidade para sua existência.

Do mesmo modo tratamos nossas fontes, tomando suas alocuções como verdades. Estas foram analisadas em seu duplo caráter: de repetição daquilo que o tempo permitiu dizer e, simultaneamente, de criação fomentada pelo personagem-enunciador. Ou seja, empregamos o termo visualização para nos opormos à ideia de representação, pois consideramos que o primeiro é mais adequado para sugerir que não existe nenhum acobertamento da realidade nos momentos em que se produziram histórias, definições, descrições, teorias. Há, sim, produção de realidade no instante mesmo em que se toma determinado acontecimento como problemático e, por conseguinte, promotor de reflexão e discurso. Contrariamente, o termo representação corresponderia a um tipo de análise em que os discursos são tidos como signos a encobrir uma realidade à espera de sua elucidação definitiva (FOUCAULT, 1999a).

Pretendemos, pois, tratar os enunciados na condição de instantâneos do presente (AQUINO, 2007). Estes seriam produzidos a partir dos condicionantes de seu tempo, abrigando problematizações próprias à sua época e criando objetos coerentes com a formação cultural à qual pertencem. No entanto, nosso olhar arqueogenealógico, voltado a inquirir o presente, somente poderia se fixar nos escritos que, por estranhamento ou naturalização, estivessem profundamente estabelecidos em nossa experiência coeva. Ou seja, escritos formuladores de objetos que emergiram em determinados períodos, responderam a problematizações de época e, por vias intrincadas, estendem-se em nossas reflexões presentes.

Destarte, nossa opção metodológica impediu-nos de projetar cronologias, afinal, consideramos que a linearidade na formulação do discurso histórico prendê-lo-ia à suposição de uma história unívoca. Tampouco a composição de sequências causais nos seria útil, já que ela nos traria a crença em algum tipo de teleologia. Coerente com tais premissas, nosso esforço de pesquisa obrigou-nos a debruçar-nos sobre práticas que, em algum nível, permitissem-nos questionar nosso presente.

Das práticas que potencialmente se nos apresentariam como campo fértil para questionar a atual relação entre educação e saúde, elegemos a psicopedagogia escolanovista e a produção acadêmico-pedagógica contemporânea. Atribuímos a tal solo enunciativo, portanto, o caráter de fontes empíricas que se nos evidenciaram como séries discursivas relevantes para o intento da investigação. 
A primeira das séries eleitas foi a supracitada coleção Bibliotheca de Educação, editada pela Companhia Melhoramentos de São Paulo, que, entre 1927 e 1941, ${ }^{4}$ publicou obras compiladas por Lourenço Filho com o fito explícito de estabelecer as bases científicas daquilo que então se nomeava Escola Nova no Brasil.

A segunda série escolhida, tal como apresentado, foi constituída por artigos publicados em 18 dos mais qualificados periódicos pedagógicos brasileiros entre 1993 e 2013. Tal arquivo foi constituído com o fito de analisar referências ao escolanovismo que nos possibilitassem surpreender as opções temático-metodológicas que estariam escorando o atual debate acadêmico acerca da aproximação entre educação e saúde. Nessa etapa da pesquisa, a Escola Nova foi tomada no mesmo sentido daquilo que Foucault (1999c), ao analisar a escrita de Raymond Roussel, chamaria de máquina. Ou seja, sugerimos que os autores compilados teriam desenvolvido um procedimento de análise por meio do qual, aproximando-se ou afastando-se do escolanovismo, recuperando ou descartando os temas e objetos do movimento, garantiriam sua inserção em tal ou qual linhagem investigativa acerca da pedagogia atual.

Fosse pelo fato de se tratar de uma iniciativa escorada na atuação de um editor brasileiro profundamente engajado na política educacional da primeira metade do século XX, fosse pela referência a critérios de publicação de artigos em periódicos acadêmicos, a ordenação de enunciados em termos dos temas abordados e das práticas descritas por eles possibilitou-nos investigar tanto as diferentes racionalidades evidentes em cada um deles quanto as similitudes presentes nos processos analíticos utilizados.

Tal procedimento levou-nos a flagrar a construção de objetos, o deslocamento de sentidos, a ascensão de autoridades, a consagração de gestos etc. Estivemos atentos às práticas que diante de nós se deslindavam, apontando veredas para que construíssemos racionalidades entre estratégias de poder emergentes nos diferentes tempos e lugares estabelecidos pela pesquisa. Ademais, focalizando o "sistema vertical que podem formar as séries" (FOUCAULT, 2007, p. 11), tornamos viável uma história que não fosse global/total, mas, ao menos, geral.

Ao tomar tal conjunto de enunciados confinados por determinada motivação e alinhados em determinada extensão temporal, ambicionamos observar a emergência e a superação de objetos, a cristalização e o abandono de prioridades, a instalação e a

\footnotetext{
${ }^{4}$ A coleção Bibliotheca de Educação perdurou de 1927 a 1979. Nesta pesquisa, nossa atenção prende-se ao período de 1927 a 1941, pois nele se concentrou a totalidade das primeiras edições das obras e, portanto, pudemos flagrar a psicopedagogia escolanovista em sua condição de emergência.
} 
desmontagem de consensos, sempre no intuito de criticar profundamente o que nosso arquivo entronizou como verdades acerca daquilo que nele se proferiu como o corpo do humano, do infante, do educando, do cidadão etc.

Dessa maneira, circulamos em torno de um "corpo inteiramente marcado de história e a história arruinando o corpo" (FOUCAULT, 2004a, p. 22). Ao abordarmos os enunciados perpetrados pela psicologia, psicopedagogia, psicanálise, psicotécnica, higiene mental, filosofia e sociologia, estivemos ativamente preocupados em observar os consensos, as naturalizações e as recomendações dirigidas aos indivíduos em investigação e responsáveis por produzir modos de subjetivação nos quais os corpos individuais estariam inseridos em jogos estratégicos e polêmicos (FOUCAULT, 2001a).

Também se justifica desse modo a análise dos enunciados atinentes à clínica anatômica do século XIX e dos relatos de práticas biotecnológicas coevas, uma vez que eles se dirigem a uma noção de corporeidade na qual o corpo foi tomado ora como objeto do poder médico, ora como espaço da livre escolha daquele que o habita. Em tais práticas sociais voltadas ao corpo, destacamos a forja de dois objetos específicos: o corpo doente e o corpo aprimorável, respectivamente. Entretanto, não tomamos a fala dos clínicos e dos biotecnólogos em sua exterioridade, nem buscamos subtrair de suas definições ecos de teorias englobantes - tais como as referências a genéricos conceitos de eugenia, higienismo ou positivismo - criadas em outros tempos ou lugares.

Interessaram-nos as palavras efetivamente pronunciadas, os jogos de sentido, as consonâncias emitidas no momento mesmo em que se investigaram as causas do sofrimento corpóreo ou de seu aprimoramento. Enfim, vislumbramos nesses campos discursivos a constituição de cânones para a visualização de corpos anatômicos e sintéticos, corporeidades em que as codificações fisiológicas e moleculares orientariam a conduta individual rumo à saúde.

As alocuções anatomistas e biocientíficas foram então consideradas não como falseamentos, mas como verdades; verdades criadas arbitrariamente no embate entre os experts e os indivíduos em estado de sofrimento ou inapetência. As prescrições e intervenções nos corpos enfermiços ou incompletos foram analisadas em termos de tentativas efetivas de cura e aperfeiçoamento, e não como meras aplicações de procedimentos padronizados. Nesse processo, espreitamos incongruências, desvios de intenções, combates e fracassos na produção daquilo que se poderia intitular corpo cibernético ou corpo anatômico.

O critério para a delimitação temática do presente estudo não se orientou pela busca de grandes teorias. Além disso, os médicos e biocientistas compilados não foram tratados como 
icônicos teorizadores ou pais-fundadores, mas como personagens inseridos em práticas sociais que os constrangiam e, ao mesmo tempo, impulsionavam-nos em direção a determinadas invenções.

Os referenciais metodológicos de que partimos permitiram-nos entender os campos discursivos elencados como espaços de produção de subjetividades. Em tais campos instituirse-iam objetos sem os quais raramente se poderia falar sobre aprendizagem e saúde. Dessa forma, por exemplo, consideramos que depois do escolanovismo, das práticas da higiene mental e da pedagogia orientada pela psicologia experimental, nunca mais se pôde falar em educação sem que termos como inteligência, atenção, vontade, temperamento, democracia, experiência e liberdade fossem pronunciados.

Essas conexões não foram aqui tomadas como meros efeitos de preconceito dos dominantes em relação aos dominados, tampouco foram vistas como produto de simples imposições normativas, ou mesmo como justificativas para ações disciplinares stricto sensu. Utilizamos com parcimônia vocábulos como ideologia, normalização e disciplina, de modo que seus significados se restringiram ao que foi estritamente enunciado pelos autores abordados, sem qualquer pretensão totalizante.

Assim, a pesquisa sobre a visualização psicopedagógica e sua posterior apropriação acadêmica levou-nos a formular uma história da educação que se fixasse na lenta e paciente sucessão de problematizações engendradas por eminentes especialistas escolares, sempre dedicados a estabelecer discursos baseados naquilo que eles mesmos definiam como a própria natureza do aprendizado e, por conseguinte, do aprendiz. Especulamos que uma inusitada natureza humana teria sido formulada no momento mesmo em que se tentava instituir o modelo escolar como fundamento para a constituição de um humano regenerado, livre ou, ao menos, cidadão.

Conforme apresentado até aqui, não pretendemos encontrar um sujeito a-histórico que teria sido, ao longo do tempo, modificado pela ação de procedimentos constrangedores, preconceituosos ou forjadores de sentido. Aventamos o corpo doente produzido pelas práticas anatômicas do século XIX como uma imagem-síntese do processo que culminou na oficialização das práticas médicas daquele período. Em direção semelhante, o sujeito contemporâneo teve investigada sua formulação na virtualidade do imageamento de seu corpo, nas probabilidades genéticas e nas especulações sobre sua estrutura neuronal. 
Esperamos pouco da análise. Não costumamos fazer ou ler teses propositivas. Propomo-nos apenas a investigar as sutilezas que saltam à vista na superficialidade dos enunciados autonomeados médicos, pedagógicos, cibernéticos e psicológicos.

Do encontro entre saúde e educação, supomos, surgiram produções fantásticas. Foi-se capaz, por exemplo, de diuturnamente manter milhões de crianças em espaços exíguos durante boa parte de seus dias, imóveis ou movimentando-se comedidamente sob a autorização dos mais velhos. A crença de que esse confinamento garantiria algum grau de salubridade ajudou a travar as trancas, a subir os muros e a afastar as escolas da vida das cidades.

Assim, acreditando que fora das ruas poder-se-ia evitar a delinquência, internaram-se infantes em escolas. No interior delas, muita atividade, mais ou menos animação, mas sempre a promessa de bem-estar, adequação e desenvolvimento. Convocados ao autoaprimoramento, aprenderam a ler, a escrever, a cantar e a desenhar. Ao fim de poucos anos, os educandos modernos já conheciam seu desempenho, já se comparavam com seus semelhantes e, nesse processo, já recebiam sua dose de atenção dos professores.

Ousamos pensar que, caso as escolas não existissem, crianças, meninos, infantes, pivetes provavelmente estariam correndo por todos os lados em vastos espaços da cidade, gritando, brigando, roubando, morrendo. Não é difícil entender a fúria dos Estados modernos ao fundarem escolas. Sem elas, obviamente não existiriam transtornos escolares - estes sempre narrados como disfunções cerebrais, em localidades encefálicas bastante definidas, suscetíveis a tratamentos químicos, com marcos biológicos que, conforme pesquisas, levam a dados genéticos auspiciosos. Diagnosticados em centenas de países, tais transtornos são hoje a razão de um sem-número de terapias, um tesouro para as empresas farmacêuticas e para as corporações médicas, psicológicas etc.

Não existiriam portadores de transtornos escolares se não existissem escolas: fórmula banal, mas de uma brutalidade estonteante.

Pensar a escola no contexto de promoção das práticas anatômicas, psicopedagógicas e neurocientíficas é compreendê-la no processo de manipulação autoconsentida da vida: produção de mais vida; produção de vida a partir de matéria inorgânica; verificação dos fluxos da vida, de seus nutrientes, de seus ritmos, de sua longevidade. É esse território que almejamos deslindar ao estudarmos o intercâmbio entre biociência, escola moderna e medicina. 


\section{Calibragem da luz: luminosidade anatômica}

Mary Wollstonecraft Shelley (1996, p. 56) assim imaginou o despertar de seu Prometeu moderno:

Era já quase uma hora da madrugada; a chuva batia tristemente nas janelas, e minha vela estava quase consumida quando, ao lusco-fusco da luz bruxuleante prestes a extinguir-se, vi abrir-se o baço olho amarelo da criatura. Ela respirava com dificuldade, e um movimento convulsivo agitava seus membros.

Como posso descrever minhas emoções ante aquela catástrofe, como reescrever aquela ruína que eu, com esforço infinito e zelo, havia tentado formar? Seus membros eram bem proporcionados, e eu havia escolhido e tralhado suas feições para que fossem belas. Belas! Meu Deus! Sua pele amarela mal cobria o revelo dos músculos e das artérias que jaziam por baixo; seus cabelos eram corridos e de um negro lustroso; seus dentes alvos como pérolas. Todas essas exuberâncias, porém, não formavam senão um contraste horrível com seus olhos desmaiados, quase da mesma cor acinzentada das órbitas onde se cravavam, e com a pele encarquilhada e os lábios negros e retos.

Em 1818, ambicionando criar uma história de horror, a iniciante escritora forjou uma imagem que, desde então, raramente esteve ausente de reflexões e debates acerca das relações entre ciência e natureza humana.

Na primeira aparição da obra de Shelley no cinema, em 1910, o diretor James Searle Dawley apresentou a história da criatura e de seu criador numa película em que a instigante criação do Dr. Vitor Frankenstein foi encenada como um monstro invejoso e deformado, enquanto o cientista era identificado a algo como um inocente e bem-intencionado jovem à procura do mistério da vida. ${ }^{5}$

Sucederam-se centenas de aparições em filmes, séries de TV e publicações variadas. Nelas, a criatura foi apresentada como um personagem ora assustador, ora engraçado, efetivando-se como uma formulação inusitada de um ser sobre-humano produzido pela intervenção científica. A intensa circulação da história no imaginário contemporâneo, acrescida das questões evocadas pela tópica da forja científica de corpos humanos, atraiu nossa atenção.

Diante da obra de Shelley (1996), observamos um cientista na busca incessante pelo princípio gerador de toda vida. Para tanto, parte ele da ideia de que, "para examinarmos as causas da vida, precisamos recorrer à morte" (p. 50). Tal pretensão acabou por produzir um

\footnotetext{
${ }^{5}$ Versão completa do filme disponível em: 〈https://www.youtube.com/watch?v=8hym4dWvxSo $>$. Acesso em: 17 fev. 2015.
} 
ser de 2,4 metros de altura e "proporcionalmente largo" (p. 52). "O desgraçado, o infeliz monstro" (p. 57) movia-se desajeitadamente, causava horror a todos que o contemplavam e exibia uma postura ameaçadora e repugnante.

Porém, em seus primeiros contatos com os humanos, a criatura revelou-se amistosa e ingênua. Sua bondade, combinada a um desejo de aceitação, tornaram-na um ente esforçado e disciplinado. Sua descomunal força desdobrava-se em habilidade para escalar, saltar e correr. Sentia pouco frio, alimentava-se de raízes e frutas, repousava em charnecas, desertos, cumes gelados e cavernas. Sobrevivia com pouco e aprendia muito rápido. A existência virginal daquele ser fazia dele um apreciador da vida: pássaros, flores, rios e homens encantavam seus olhos inocentes. A necessidade de se manter afastado do convívio humano induzia-o a observar, deduzir, arquitetar.

A criatura tinha tudo, podia tudo, desejava tudo, mas não conquistara o apego dos seres humanos. Confinada a uma natureza inusitada, era repugnante para a espécie daquele que o havia criado. Restrito à condição de experimento científico, somente a seu criador o demônio poderia recorrer.

Para superar o isolamento, uma aspiração: "pelo amor a uma criatura, eu faria a paz com toda a espécie" (p. 140). Requisitou ao criador uma companheira para que pudesse compartilhar a estranha singularidade. Com ela, intencionava viver distante dos humanos e, talvez, criar seus descendentes nas florestas desabitadas da América.

Dr. Frankenstein negou o pedido. Mesmo o aceitando a princípio, refletiu sobre o risco de se propagar "pelo mundo uma raça de demônios, que poderia tornar a própria existência da espécie humana precária e cheia de terror" (p. 160). Destruiu o segundo experimento na iminência de seu desfecho.

A negação do cientista levou o monstro à fúria e à consequente vingança, desdobrada em morticínio. Após perseguições implacáveis e tormentos horrorosos, sucumbiram o doutor, seus parentes, seus amigos e sua criatura.

Do mar de especulações geradas pela novela inaugural de Mary Shelley, voltamo-nos à problematização que sustenta a presente pesquisa: o experimento do Dr. Frankenstein viveu e morreu em busca de uma espécie à qual pudesse se identificar. Ele não era humano, e todos que o encontravam apercebiam-se disso. Sua aparência de cadáver animado repugnava, enquanto ele só pretendia compaixão. Buscava, então, alguém para compartilhar sua miserável condição e, ao seu lado, aceitar o destino imposto pela presunção de seu criador. $\mathrm{O}$ monstro, porém, tornou-se violento quando viu negada a possibilidade de reconhecer a si 
mesmo por meio da imagem de um semelhante seu - ou seja, algum outro ser constituído a partir de matéria morta quimicamente ativada.

Desponta o tema de determinada noção de natureza em relação a uma discursividade científica que a produz, depois a regenera e, então, elimina-a. Ao adentrarmos a história desse tema, encontramos a medicina oitocentista, que se apropriou do corpo morto e narrou a vida humana a partir dele. Foucault (2004b) afirmou que quando a medicina instituiu o cadáver como foco de seu olhar, a morte se instaurou como a luz que revelaria o funcionamento da vida.

O entendimento do morto como cânone para a narrativa da vida remonta ao século XVI, mais especificamente ao ano de 1543, quando Versalio publicou De humani corporis fabrica, obra que, segundo Francisco Ortega (2008), permitiu o surgimento da anatomia científica moderna.

Ao longo do século XVI, as dissecações eram realizadas como espetáculos em teatros anatômicos, no interior dos quais os médicos apresentavam ao público suas habilidades de vivissecção e atraíam a curiosidade de muitos. Segundo Ortega (2008), essa prática teria perdurado até o século XIX, quando os mestres anatomistas começaram a expor suas técnicas no interior das academias de medicina. No ambiente universitário, a anatomia então passaria a conviver com a fisiologia, e os "fisiologistas envolveram-se cada vez mais com a determinação de leis biológicas e relações causais" (p. 125).

Naqueles primeiros tempos da anatomofisiologia, segundo Georges Canguilhem (2006b), o normal seria distinto do patológico apenas por questões quantitativas; portanto, a fim de se descrever o desenvolvimento de uma doença, dever-se-ia estabelecer critérios objetivos para o funcionamento do corpo. Tal objetividade seria alcançada por meio da definição dos limites entre irritação e excitação dos tecidos e órgãos que formariam tanto o corpo doente quanto o normal. Canguilhem (2006b), ao analisar as contribuições de Claude Bernard para a fisiologia do século XIX, atribuiu ao eminente médico francês a introdução de "argumentos controláveis, protocolos de experiências, e sobretudo métodos de quantificação" (p. 42), tais como a medição da glicemia, da glicogênese, do calor de vasodilatação etc., o que muito contribuiu para a definição do corpo humano em situação de normalidade.

Canguilhem (2006b) opôs as concepções de René Leriche - médico também francês, atuante no século XX - às de Claude Bernard, na medida em que o primeiro teria invertido o caminho descritivo da doença. Enquanto, para Bernard, o patológico adviria de um déficit ou de uma hipertrofia das funções orgânicas, para Leriche, a fisiologia somente poderia ser conhecida "por abstração retrospectiva da experiência clínica" (p. 64). Ou seja, na concepção 
de Leriche, seria impossível definir uma doença antes que ela afetasse o corpo do indivíduo acometido. Uma vez que o mal físico não estaria pressuposto no organismo, ele somente poderia ter sido provocado por uma afecção externa ao doente.

Foucault (2004b), ao se debruçar sobre a época em que se teria dado o advento da medicina positiva, ponderou que "a medicina do século XIX foi obcecada por esse olho absoluto que cadaveriza a vida e reencontra no cadáver a frágil nervura rompida da vida" ( $\mathrm{p}$. 184). Apreciando o tema da medicina anatômica no século XIX brasileiro e acompanhando as análises de Foucault (2004b), de Canguilhem (2005, 2006b) e de Ortega (2005), depreendemos que um olhar sobre o corpo humano cujo foco partisse da associação entre anormalidade e desvio e, em seguida, estabelecesse o funcionamento orgânico normal como medida de salubridade seria, ainda hoje, um caminho amplamente percorrido por diferentes vertentes das ciências da vida.

Tal visualização explicita-se na descrição de Ortega (2005) sobre a maneira como os médicos gradativamente teriam prescindido do toque em seus pacientes. Segundo o autor, o século XIX - mais detidamente, a era vitoriana - foi marcado pela separação entre as atividades do cirurgião, que teria a tarefa de tocar o cliente, e a ação do médico, que, utilizando aparelhos como estetoscópio, oftalmoscópio e laringoscópio, usava os sentidos da audição e da visão para especular sobre as condições dos pacientes. Essas práticas teriam sucumbido ante a conquista visual do corpo, notadamente após a generalização do uso do raio $\mathrm{X}$, inventado em 1896. A partir daí, entronizar-se-ia “o privilégio da visão, proporcionando um modelo de corpo como objeto, um conjunto de fragmentos sem substância ou materialidade" (ORTEGA, 2005, p. 246). Assim como na ficção de Shelley, a fragmentação instituída pela abordagem anatômica do humano viabilizaria a recomposição biomédica do corpo por meio da organicidade a ele atribuída.

Ao analisarmos as visualizações estabelecidas pela Escola Nova, vislumbramos, na organicidade operada por seus autores, uma importante conexão entre o discurso psicopedagógico e o até hoje consensual approach anatômico da vida. Nesse sentido, encontramos abordagens tradicionais como as do médico legista Afrânio Peixoto, em cuja obra Noções de história da educação registra: "a educação olha esse futuro, nossa preocupação, tentando o aperfeiçoamento dos órgãos desse imenso e imortal organismo que é a sociedade" (PEIXOTO, 1936, p. 9). Em texto posterior, intitulado Um grande problema nacional - qual seja: a educação -, Peixoto (1937, p. 16) deixou claro que "a escola primária não é feita para encher de instrução a criança, mas sim ajudar a educação, isto é, o desenvolvimento físico, intelectual, social e moral da criança”. 
A presença de médicos na composição de enunciados dirigidos à vida escolar brasileira não é nenhuma novidade, fosse na década de 1930, seja na atualidade. No entanto, tal como supomos, o escolanovismo tornou responsabilidade individual a preservação da vida biológica, aquela vida oferecida pela natureza e decodificada pelo cientista.

Ademais, a noção de natureza presente nos textos instituidores da Escola Nova brasileira motivou-nos a refletir sobre algumas associações que, apesar de historicamente datadas, nunca deixaram de impregnar o linguajar circulante de fazeres e dizeres, fossem eles educacionais ou médicos. Trata-se das associações entre educação e futuro, educação e aperfeiçoamento, educação e desenvolvimento físico, social e moral, além da perene, embora contestada, analogia orgânica para o funcionamento social.

O fato de a corporação médica voltar seu olhar para a seara pedagógica e demonstrar as possibilidades de expansão do organismo social por meio de intervenções racionais e marcadamente científicas é algo corriqueiro na história da educação brasileira.

José Gonçalves Gondra deteve-se em enunciados desse tipo. Em sua obra Artes de civilizar, o autor fez uma extensa pesquisa sobre as teses aprovadas e chanceladas pela Academia Imperial de Medicina do Rio de Janeiro e pela Faculdade de Medicina do Rio de Janeiro, a fim de "investigar a produção de um vocabulário e uma gramática educacionais integrados ao campo da medicina" (GONDRA, 2004, p. 83).

Em seus estudos, que percorreram meados do século XIX e o início de século XX, Gondra (2004, p. 83) chegou a sugerir que "a própria invenção da educação escolar no Brasil se deu a partir de uma matriz médica". Segundo o autor, por meio da higiene, as proposições médicas ter-se-iam unificado e, a partir da escola, suas determinações teriam alcançado todos os espaços sociais.

Desde o local de instalação dos colégios e das casas, passando pelos cuidados com o fluxo dos fluidos corpóreos, até chegar ao regime alimentar e de exercícios, todos os campos do viver humano passariam a receber definições e aconselhamentos médicos. Nesse itinerário, noções como a de limpeza seriam reconhecidas como problemas não apenas de saúde, mas também de moralidade. Criar um cidadão moral, na visão dos médicos do século XIX, seria tarefa, antes de tudo, da educação escolar. Esta deveria instruir, formar e sanear o corpo da criança, que, por meio do convívio com a família, irradiaria saúde por todo o campo social. Destarte, a crença no processo civilizatório agregar-se-ia às definições atinentes ao desenvolvimento corporal das crianças.

Segundo Gondra (2004, p. 343), “a natureza é tomada como critério que ordena o início da escolarização, bem como o que e como deve ser estudado, hierarquizando e 
subordinando, desse modo, a aprendizagem ao desenvolvimento biológico". Assim, a analogia do corpo em crescimento proporcionando o progresso da sociedade não apenas justificaria a ação médica sobre a população escolar, mas também permitiria a irradiação da higiene - ciência integral, ciência da infância, ciência da escola, conforme aventa Gondra (2004) - para o conjunto da coletividade, particularmente a urbana.

No interior do discurso médico oitocentista, utilizar-se-ia então, segundo o autor, uma noção específica de natureza cujos alicerces fixar-se-iam em um corpo físico em maturação, capaz de relações sociais que permitiriam o incremento de habilidades cognitivas e morais ao longo do tempo.

Na gramática segundo a qual os médicos dessa época enunciavam a natureza humana - tal como na posterior perspectiva escolanovista -, as funções intelectuais ganhavam destaque, uma vez que "exercitar o cérebro produziria um conjunto de habilidades tipicamente humanas que definiriam aquilo que podemos nomear de inteligência humana" (GONDRA, 2004, p. 355). Para tanto, os professores teriam uma função essencial, pois deveriam conhecer os mecanismos cerebrais para poder intervir cientificamente em seu aperfeiçoamento. Uma educação doravante científica, segundo os médicos compilados por Gondra (2004, p. 376), seria aquela fundada na experiência antes da instrução, uma vez que "a verdadeira sede da educação se localizaria nos centros nervosos, pois neles existiria a faculdade de desenvolver e aperfeiçoar os movimentos".

O exercício do corpo para o avanço de todas as estruturas humanas presentes no indivíduo seria a base para seu desenvolvimento cognitivo. A inteligência integraria o homem à natureza lato sensu e, por meio da educação da criança, iluminar-se-ia de razão toda a civilização. Tal ação não aconteceria sem que, além do sistema nervoso, a vontade também fosse exercitada; "a ginástica das vontades seria, nesse sentido, a medida preventiva mais eficaz para se educar moralmente os indivíduos, posto que, por seu intermédio, as interioridades seriam construídas e amoldadas de forma livre" (GONDRA, 2004, p. 434). Assim, armar-se-ia no discurso médico brasileiro do século XIX a sequência prevençãodiagnóstico-cura por meio do controle discursivo sobre a vontade, a inteligência e o exercício. Conforme aventamos, tal circuito manteve-se no período escolanovista.

A partir das análises realizadas por Gondra (2004), inferimos que o século XIX brasileiro viu emergirem princípios educativos com o objetivo de congregar na escola funções formativas, morais e, antes de tudo, terapêuticas. Esse projeto racionalista do século XIX, supomos, não deixou de frequentar os projetos redentores modernos. 
Conforme propuseram Machado et al. (1978), tais projetos incluíam, desde o século XIX, a reivindicação de uma urbanidade constituinte de uma utópica sociedade perfeita, no interior da qual preponderariam normas de circulação e de convívio orientadas pela racionalidade médica. Entrementes, a disputa por uma sociabilidade medicamente orientada evocou um intrincado processo de autonomização do saber médico, cuja ponta de lança teria sido a institucionalização do exercício da medicina.

Paradoxalmente, é notável que o caráter público da medicina, tanto no Brasil do século XIX quanto na Europa do século XVIII, foi simultâneo ao seu desprendimento em relação ao Estado. Conquanto os médicos mantivessem um permanente contato com as instâncias administrativas, suas sugestões passaram a ser apresentadas como aconselhamentos e, mesmo quando se tornavam medidas legais, sobrepunham-se aos interesses políticos, apoiando suas determinações em argumentos humanistas, civilizatórios e, sobretudo, científicos (FERREIRA, 1996).

A fundação da Academia Imperial de Medicina no Brasil de 1835 corrobora esse fato. O empenho da corporação médica no Brasil, convulsionado pelas revoltas regenciais, desdobrou-se na organização e no reconhecimento definitivo de sua atividade como portadora de "uma prática de ordenação, de documentação, de registro" (MACHADO et al., 1978, p. 216), no sentido de instalar demandas coerentes com temas intrínsecos à referida corporação.

Ação semelhante foi descrita por Foucault (2004b) em suas considerações sobre a instalação da Sociedade Real de Medicina francesa em 1778. Tal órgão, apesar de sustentado pelas expensas estatais, voltou-se, segundo o autor, para uma consciência coletiva na qual "o olhar médico circula, em um movimento autônomo, no interior de um espaço em que se desdobra e se controla; distribui soberanamente para a experiência cotidiana o saber que há muito dela recebeu” (p. 33).

Ademais, Foucault demonstrou como a instalação do poder médico nas cidades modernas foi acompanhada pela gradual conquista do corpo pelos procedimentos da anatomoclínica. Tal conquista, "na medida em que ela diz respeito ao ser do homem como objeto de saber positivo" (p. 217), teria possibilitado à corporação médica estabelecer uma verdade abrangente e, ao mesmo tempo, penetrante.

Tendo em vista o estabelecimento da verdade médica no Brasil, compilamos periódicos oficiais publicados por órgãos formalmente reconhecidos pelo Estado Imperial brasileiro e vasculhamos neles algumas recorrências temáticas.

Partimos da Revista Médica Fluminense, publicada entre 1833 e 1841, e chegamos à Revista Médica Brasileira, entre 1841 e 1843, ambas desde 1835 chanceladas pela recém- 
fundada Academia Imperial de Medicina. Em continuidade, mantivemos a recolha temática nos Annaes de Medicina Brasiliense, periódico que substituiu a Revista Médica Brasileira e que foi publicado pela mesma Academia entre 1851 e 1885. Nesse levantamento, ativemo-nos à gramática por meio da qual determinado setor da intelectualidade brasileira estabeleceu os cânones positivo-liberais de visualização da vida e, por conseguinte, as perspectivas argumentativas no interior das quais emergiu a expertise médica oficial no Brasil.

A fim de analisar a gramática impetrada pelos experts no alvorecer do poder médico no Brasil, optamos por compilar periódicos oficiais, uma vez que, mesmo na condição de minoritários em relação aos não oficiais no século XIX (FERREIRA, 1996), eles nos permitiram reconhecer o esforço da corporação médica para, ao mesmo tempo, legitimar suas teorias e estabelecer os critérios de convívio urbano aceitos pelo Estado brasileiro em formação. Destarte, decidimos auscultar tais enunciados médicos com o fito de investigar a maneira como a racionalidade ali desenvolvida relacionava-se com uma perspectiva inaugural - se não original, ao menos oficialmente assumida como embrionária - voltada à produção de um olhar médico para o corpo, no sentido de governar fosse o corpo do indivíduo, fosse o corpo da cidade que o abrigava.

Ao historiar a implantação dos periódicos médicos no Brasil do século XIX, Luiz Otavio Ferreira (1996) pretendeu tratar da legitimação social conquistada pela medicina ao longo do processo de sua institucionalização. Nesse percurso, o autor apontou algo que consideramos fundamental para nosso campo de investigação: o processo de reconhecimento popular da atividade médica teria caminhado lado a lado com a ascensão das práticas higienistas determinadas pela corporação.

O higienismo, segundo o autor, ter-se-ia alastrado tanto no campo acadêmico quanto na administração pública a partir da Sociedade de Medicina do Rio de Janeiro, fundada em 1829, que atuaria como célula-mater para a institucionalização da higiene pública no Brasil. A medicina higienista teria incorporado a "estatística, a geografia, a climatologia, a demografia, a antropometria, a medicina legal, a clínica médica etc., para a produção dos conhecimentos científicos" (FERREIRA, 1996, p. 70), cuja atenção dirigir-se-ia para a "avaliação das relações entre sociedade, natureza e doenças brasileiras" (p. 71).

Consideramos que o higienismo brasileiro é um importante mirante para localizar aquilo que Foucault (2008b), no contexto do liberalismo europeu, definiu como o problema da emergência da população no processo de constituição de uma nova racionalidade política dedicada a encaminhar as novidades geradas pela instauração das cidades modernas. 
Em $O$ nascimento da clínica, Foucault (2004b, p. 36) pinçou uma bela cena dessa medicina social: "Em uma sociedade finalmente livre, em que as desigualdades são apaziguadas e onde reina a concórdia, o médico terá apenas o papel transitório a desempenhar: dar ao legislador e ao cidadão conselhos para o equilíbrio do coração e do corpo". Tal seria, segundo nossa interpretação de Nikolas Rose (1997), a responsabilidade assumida por esse tipo de expertise liberal quando a medicina efetivou as bases para o exercício de seu poder: utilizar seu credenciamento junto ao Estado para criticá-lo e, então, no mesmo golpe, aconselhá-lo a partir de sua visão de especialista da vida.

A corporação médica, segundo Foucault (2004b), reivindicou autonomia em relação ao Estado e, a partir dessa exterioridade, adquiriu suficiente respeitabilidade para criar demandas a serem resolvidas pelos governantes. A medicina, mesmo quando parasitou as finanças estatais, nunca deixou de ser uma tecnologia impositiva e, concomitantemente, curativa.

A esse respeito, interessou-nos, pois, analisar como o higienismo brasileiro alçou seus temas à condição de objetos científicos. Também pretendemos observar de que modo alguns desses temas se relacionaram com os diferentes campos da produção intelectual no período. Além disso, atentamos para o percurso traçado pelos médicos brasileiros em direção ao seu posicionamento perante o Estado por meio das relações próprias do jogo do expert (AQUINO, 2013). Um jogo que foi atribuído por Julio Groppa Aquino (2013) ao professor contemporâneo, mas que bem poderia ter sido jogado pelos referidos higienistas: "uma ação à distância sobre as escolhas cotidianas dos cidadãos, estas subscritas às normas, aos valores políticos dominantes e aos padrões de consumo vigentes, não obstante reclamem para si a chancela de neutralidade e de livre-arbítrio" (p. 205).

Em 21 de dezembro de 1835, quatro anos após a coroação do novo soberano, o rapaz, então com 19 anos, compareceu a uma das salas do Paço Imperial para assistir à Sessão Pública de Instalação da Academia Imperial de Medicina (RMF, abr. 1836). Na ocasião estiveram presentes 35 membros titulares, cinco membros honorários e um membro correspondente. À audiência, convocados por cartas de convite, compareceram autoridades e notabilidades das áreas civis, militares, médicas e literárias da corte, além de diplomatas de diferentes países. A solenidade, assim como as responsabilidades da Academia, fora 
cuidadosamente organizada e discutida em sessões preparatórias, desde - conforme as atas - 5 de novembro de 1833 (RMF, jul. 1835).

O Império fez-se presente na inauguração por meio da publicação do decreto que determinava a conversão da Sociedade de Medicina do Rio de Janeiro em Academia Imperial de Medicina do Rio de Janeiro. Também o Império atuou na nomeação dos futuros membros e no sustento material à publicação da Revista Médica Brasileira desde 1841. Além do apoio institucional, Sua Majestade costumava tomar assento em algumas sessões da Sociedade e continuou comparecendo em reuniões da Academia Imperial. O estreito vínculo dos acadêmicos com o Império facultava-lhes assumir, em parte, a responsabilidade material pela instituição; prova disso é que votaram, em sessão preparatória de 17 de novembro de 1835, a favor da manutenção de cotas mensais para sustento da Academia (RMF, abr. 1836).

Em discurso proferido pelo Sr. Dr. Meirelles na primeira sessão preparatória de 4 de outubro de 1834 (RMF, out. 1835), aquele que se tornaria o primeiro presidente da Academia Imperial de Medicina discorreu sobre a missão dos acadêmicos perante o jovem país que então se formava. Alegou que o saber médico deveria ser considerado parte da instrução geral do povo, demonstrando sua importância na constituição da civilização. Para tanto, os acadêmicos deveriam se conscientizar de sua importância na expansão da capacidade moral dos brasileiros, pois seria por meio dela que se naturalizaria a busca pelo crescimento intelectual e que, por conseguinte, o país alcançaria o patamar civilizatório das velhas nações.

A missão assumida pela corporação médica no sentido do desenvolvimento intelectual, moral e civilizatório e sua ambígua pretensão de autonomia diante dos órgãos estatais caracterizaram boa parte dos enunciados proferidos pelos médicos que redigiram artigos nos periódicos oficiais emitidos sob a chancela da Academia Imperial de Medicina.

Após uma apreciação das publicações nos 51 anos em que perduraram tais periódicos, pudemos levantar alguns temas que, em razão da recorrência ou do grau de interferência nos corpos a que se dirigiam, fizeram-nos sugerir a constituição de cânones de visualização do corpo com longa duração na história de uma tecnologia de intervenção cujo cerne intercambiou definições de salubridade e escolha individual de modos de viver no Brasil.

Diante da plêiade temática, concentramos nossa atenção em três grandes conjuntos de recorrências: a busca pela especificidade das doenças nos trópicos; os procedimentos sedimentados no encontro dos médicos com os corpos doentes; e a constituição do médico como acadêmico e, portanto, como único expert autorizado a manifestar-se sobre a vida orgânico-anatômica. Evidentemente, tais temas não deram conta da totalidade dos assuntos levantados nos periódicos, mas a escolha se deu em razão de essas práticas consistirem na 
base do olhar médico para o corpo, um olhar ainda vigoroso, particularmente quando analisamos a visualização do corpo estabelecida pelo advento da Escola Nova.

No que tange à busca pela especificidade da medicina nos trópicos, os periódicos analisados persistentemente a estabeleciam a partir da comparação entre as manifestações corpóreas nacionais e as nosologias estabelecidas na Europa. Nessa perspectiva, evidenciaram-se análises que situaram a predominância, nos trópicos, de afecções crônicas, enquanto na Europa distinguiam-se manifestações agudas. Se cá predominariam moléstias na pele, escrófulas nas glândulas linfáticas e inflamações intestinais, no velho continente prevaleceriam inflamações, doenças de pele agudas e escrófulas nos ossos (RMB, mai. 1841).

Em seu Discurso sobre as moléstias que mais afligem a classe pobre do Rio de Janeiro, publicado na Revista Médica Brasileira em 1841, o Dr. José Martins da Cruz Jobim (RMB, nov. 1841) dissertou sobre as febres intermitentes - tópico sempre presente nas sessões da revista dedicadas às moléstias reinantes - que importunavam sobremaneira a capital do Império naquele mesmo ano. Intrigava-se o doutor com a violência dos retornos dos males febris, certos, sempre acelerados, o "que se não pode atribuir senão a certas condições atmosféricas" (RMB, nov. 1841, p. 345).

No tempo do Dr. Jobim, uma mulher abriu a janela de seu quarto e, após respirar o ar matinal, caiu de cama. $\mathrm{O}$ vômito, as dores no ventre e o rápido emagrecimento levaram ao diagnóstico de febre intestinal; no entanto, reparou-se uma particularidade: quase nenhum aumento de temperatura. Tal exceção emoldurava a moléstia de especificidade. Aos olhos do clínico que a atendeu, uma disenteria sem febre alta seria incongruência. Para ele, assim como para boa parte de seus colegas anatomopatologistas, a inflamação era fato comum à quase totalidade das doenças em que, evidentemente, a febre deveria estar presente.

Crente de que os ares dos pântanos inundados tanto pela imundície das casas quanto pelo "miasma vegetal" (RMB, jul. 1842, p. 102) teriam levado a sobredita enferma aos vômitos, às dores no ventre, ao rápido emagrecimento e ao roxear da pele, Dr. Jobim prescreveu uma terapêutica que consistia na aplicação de sanguessugas, emplastos e laxantes, ou seja, o mesmo tratamento dispensado a pacientes que manifestavam sintomas semelhantes, mas com presença de febre. O resultado foi feliz e a jovem livrou-se das dores e dos incômodos.

Na mesma cidade e no mesmo ano de 1841, uma afecção no intestino acompanhada de febre baixa culminou na morte de quatro irmãos. A comissão da Academia, responsável pela averiguação dessa enfermidade, concluiu que a causa geral da afetação era uma vala aberta nas proximidades da habitação dos doentes. A vala foi desentupida, o clima mudou e as 
queixas de dores no ventre acompanhadas de febre baixa diminuíram na parte da população do Rio de Janeiro observada pelo Dr. Jobim.

A disenteria era um mal bastante presente nas preocupações dos membros da Academia Imperial de Medicina. Em memória apresentada na sessão do dia 20 de outubro de 1840, Dr. Saulnier relatou suas observações durante uma viagem ao Maranhão, descrevendo um tratamento alternativo em relação à conduta comum aos colegas: por não dispor de sanguessugas suficientes, o médico empregara "evacuantes e narcóticos" (RMB, jun. 1841, p. 100) a fim de enfrentar uma febre supostamente gerada por irritação intestinal. Desconfiando de que a disenteria maranhense era proveniente de uma inflamação no fígado, Dr. Saulnier realizou autópsias em seis corpos de vítimas da dita febre. Encontrou apenas dois fígados inchados, mas não abriu mão de supor a ocorrência de uma doença hepática.

Analisando a população maranhense, seu aspecto e seus excrementos, Dr. Saulnier observou hábitos que incluíam "huma alimentação pouco substancial, abuso de bebidas alcoolicas, e de actos venereos" (RMB, jun. 1841, p. 103), e que, junto ao calor e à umidade da região, só poderiam afetar o fígado. Mesmo parcialmente desmentido pela apreciação anatômica, o médico criou uma intricada associação entre a referida disenteria e um suposto derrame de bílis no intestino, derrame este que teria provocado a irritação intestinal e a subsequente disenteria. O sucesso dos vomitórios contribuiu para comprovar sua suposição.

Na edição de novembro de 1841, o já referido Dr. Jobim teceu algumas considerações sobre febres em um sentido mais amplo. Em meio a reflexões sobre a intermitência delas nas cidades brasileiras, o furor de seus retornos e a resistência dos corpos provenientes da "Costa da Africa" (RMB, nov. 1841, p. 346), o acadêmico deteve-se em algo paradoxal ao seu olhar anatômico: a febre lesiona os tecidos, ou a lesão dos tecidos é o que provoca o aumento de temperatura observado no exame do corpo vivo?

Era fato anatômico estabelecido que, quando uma pessoa morria após longos períodos de febre, alguns de seus órgãos apresentavam tecidos lesados. Definir a antecedência da febre sobre a lesão ou seu contrário absoluto criava, na descrição do Dr. Jobim, uma arenga entre “os partidistas do systema da irritação" e "os essencialistas” (RMB, nov. 1841, p. 347). Portanto, situar-se de um lado ou de outro na fixação da origem dos males físicos obrigava o médico, coerentemente, a propor tratamentos correspondentes. Os irritadistas preferiam trabalhar com expectorantes, sudoríferos ou purgantes contra a maioria das afecções, uma vez que, para eles, todas as doenças possuíam como causa comum a inflamação de algum órgão. Para seus rivais, a essência tanto da doença quanto da reação do organismo era comum a todas as manifestações e, portanto, o indicado nesses casos seriam fortificantes, dietas e banhos, 
pois os adeptos do essencialismo restringiam-se a garantir o processo natural da moléstia ou da cura.

Ambos os métodos de intervenção apontados apresentavam resultados satisfatórios, e algumas vezes as terapêuticas apareciam até mesmo combinadas. No entanto, a despeito do procedimento que sugeriam, fossem essencialistas ou irritadistas, nunca os médicos acadêmicos deixaram de visualizar a doença como um mau funcionamento orgânico provocado pela relação insalubre do indivíduo com seu meio.

A crença na ênfase geográfica para o prognóstico levou o supracitado Dr. Jobim a reivindicar maiores estudos sobre a topografia brasileira com o fito de aprimorar o processo diagnóstico, associando cada fator ambiental ao seu correspondente elemento patogênico. Em suas averiguações, o médico levantou dados estatísticos acerca dos doentes do Hospital de Misericórdia do Rio de Janeiro e reparou a prevalência das doenças crônicas sobre as afecções agudas. Tal informação, comparada a dados europeus, permitiu a ele concordar com a hipótese de que ambientes úmidos favoreceriam a cronicidade dos males, enquanto ambientes secos predisporiam a doenças agudas.

Entretanto, tal predisposição não era absoluta. Como vimos, os hábitos dos moradores dos trópicos, principalmente da população mais pobre, somavam-se à suscetibilidade provocada pelo clima. Alcoolismo, desleixo, alimentação inadequada e uso de medicamentos inoportunos levavam à maior vulnerabilidade daquela classe de habitantes.

A hipervalorização do meio como agente de doenças foi, portanto, relativizada pela ação do hábito. A crença em uma relação específica entre topografia e costumes levou à produção de um saber médico específico para o Brasil. Evidentemente, nesse processo produziam-se aconselhamentos científicos no sentido da modificação dos aparatos urbanos e da mudança de hábitos.

Com as sucessivas levas das moléstias epidêmicas, também se modificavam as teorizações acerca das causas de propagação dos males. Ao longo dos anos em que se sucederam os números das revistas, avançaram e recuaram diferentes epidemias. Em meio à cólera e às febres intermitentes, as preocupações dos acadêmicos flutuavam permanentemente das causas para as urgências, sempre estabelecendo, tanto em um caso quanto no outro, medidas para massificar o atendimento aos enfermos.

Entre as descrições de epidemias, tratemos de uma constante na Succinta exposição do movimento sanitario da cidade do Rio de Janeiro durante o anno findo de 15 de abril de 1851 a 15 de abril de 1852 e em particular do movimento da febre amarella, apresentado ao ministerio do Imperio pelo Sr. Dr. Francisco de Paula Candido, presidente da Junta de 
Hygiene Publica. No documento, Dr. Paula Candido dedicou-se a vasculhar as causas da “primeira horrível explosão de febre amarella" (ABM, abr. 1852, p. 190) em regiões tão distantes como Ceará, Pernambuco e Bahia; Santa Catarina, Campos, Rio de Janeiro e Pará.

Para tanto, o autor revisou as tradicionais teorias acerca da propagação da febre amarela e, em sequência, analisou causas desde sempre procuradas, relativas à alimentação da população adoecida, à topologia das regiões afetadas ou às condições habitacionais das classes pobres. Tendo refutado as costumeiras causas da epidemia em questão, Dr. Paula Candido passou a discorrer sobre um elemento que, segundo ele, "se offerecerá de hoje avante sempre que se discutirem as causas determinantes do nosso movimento sanitário" (ABM, abr. 1852, p. 190). Trata-se do contágio. Este se apresentava ao sanitarista como um princípio bastante conhecido, porém insuficiente para explicar a epidemia de febre amarela, uma vez que tanto aqueles que defendiam o contágio quanto os que o refutavam pareciam, conforme os argumentos do autor, estar com justificativas incompletas.

Na visão de Dr. Paula Candido, os estudiosos que negavam a hipótese do contágio para explicar o alastramento da febre amarela defendiam causas "preexistentes e accumuladas no paiz" (ABM, abr. 1852, p. 191). A insuficiência nesse caso, segundo o autor, residiria na concomitância temporal das afecções em regiões tão distantes quanto diversas em termos de clima e condições naturais. Ou seja, sustentava o especialista que, no Pará, assim como em Santa Catarina, a febre amarela esteve presente e em nada se assemelhavam os díspares quadros naturais a ponto de neles haver condições preexistentes para a perpetuação do referido mal.

Descartada a hipótese da predeterminação natural, passou o pesquisador a discutir a possibilidade de um contágio supostamente provocado pela visita de embarcações estrangeiras provenientes de regiões sabidamente contaminadas. Também essa causa foi eliminada, pois o autor conseguiu reunir informações suficientes para afirmar que em outros anos também teria havido a presença, em nossas terras, de estrangeiros contaminados e que isso não desencadeara uma epidemia de febre amarela.

Refutadas as alegações tanto das predeterminações regionais quanto do contágio direto, passou o higienista a lançar mão de uma novidade que, segundo ele, superaria todas as citadas alegações. Conforme Dr. Paula Candido, a

[...] chimica orgânica, ao lado dos que a observação e a experiência me permitiram avaliar acerca da febre amarella durante os dous últimos annos, inspiram-me uma quasi convicção de que a communicação da febre amarella de um para outro individuo, de um para outro paiz, não se effeitua pela infecção directa da parte do enfermo para o sao; mas que exhalaçoes ou emanações do enfermo, ou do paiz infecto, levadas de qualquer modo ao 
contato ou visinhança de substancias orgânicas, prestes a se decomporem, determinam nestas substancias a decomposição que da origem ao miasma productor da febre amarella; e que estas substancias se acham as mais das vezes nas praias, bahias marítimas, e objectos que lhes estão visinhos... sem esta decomposição intermedia não ha transmissão (ABM, abr. 1852, p. 193).

Em continuidade a essa alegação, o autor passou a discorrer sobre os movimentos dos ventos e das correntes marítimas cujos deslocamentos entre os continentes e os oceanos propagariam, segundo ele, os miasmas da febre amarela. Tal apreciação operava no sentido de estabelecer critérios seguros para determinar o sentido da circulação de tais exhalações e emanações.

A explicação visava ultrapassar as limitações das justificativas anteriormente apresentadas, pois o deslocamento dos ventos elucidaria a concomitância da epidemia em regiões distantes de um mesmo país. Resolveria também a questão relacionada à infecção por contágio, já que nem todos haviam tido contato com os germens do mal, uma vez que as referidas exalações não se propagariam de modo uniforme no interior dos diferentes espaços presentes nas cidades.

Destarte, clima, topografia, disposição urbana e contágio conjugar-se-iam para produzir a devastadora epidemia. Nota-se que, segundo o olhar do sanitarista, as populações estariam constantemente vulneráveis à incidência dos miasmas. Assim, a imanência das pestilências doentias disparava os aconselhamentos da previdência higienista que, coerente com essa constatação, mantinha um constante estado de alerta, fosse quanto à individualidade das habitações, fosse quanto aos espaços públicos urbanos.

Pouco importa, em nossa análise, que as teorias médicas tenham se modificado e que hoje não se aceitem mais as teorias dos miasmas aventadas por Dr. Paula Candido. Nosso interesse dirige-se aos caminhos traçados por saberes que, ao estabelecerem "uma concepção ambientalista da medicina baseada na hipótese da relação intrínseca entre doença, natureza e sociedade" (FERREIRA, 1996, p. 69), garantiram à corporação médica "a oportunidade de falar à sociedade, criando assim as bases para a legitimação da medicina" (FERREIRA, 1996, p. 180).

Entretanto, de modo complementar às medidas sanitárias - como a canalização dos córregos, a liberação dos ventos e a educação dos habitantes -, enquanto se demandavam as intervenções ambientais, estava-se formulando um corpo especificamente tropical, depositário de doenças singulares e exposto a tratamentos próprios. Entendemos, pois, que, ao descreverem processos como o das contaminações, os anatomistas instituíam argumentos para deliberar sobre aquilo que doravante se consideraria um corpo saudável nos trópicos, ou seja: 
um organismo que funcionasse de forma a precaver-se das intercorrências próprias ao seu meio, fosse ele social, moral ou natural.

Desse modo, o corpo doente revelaria o caminho pelo qual se compreenderia a saúde. As alterações de temperatura, as obstruções, as apoplexias e demais sintomas seriam usados pelos anatomoclínicos como referências a partir das quais eles poderiam criar explicações para a defesa corporal às inflamações. O olhar dirigido aos fluxos dos órgãos excretores e ao ritmo da respiração, assim como às diferentes manifestações vitais, fundamentava uma lógica discursiva em que o funcionamento orgânico era definido ao mesmo tempo em que se elaboravam especulações sobre as disfunções.

Deliberar sobre obras contra enchentes, estabelecer o destino dos cadáveres, regulamentar os medicamentos nas boticas e garantir a limpeza dos alimentos eram apenas parte das influências dos anatomoclínicos na vida dos habitantes das cidades. O poder desses práticos, supomos, era muito mais incisivo: eles deliberavam, estabeleciam, regulamentavam e garantiam aquilo que cada um dos brasileiros deveria considerar como seu próprio corpo.

Assim, incorporar as alocuções anatômicas era muito mais do que sucumbir a um discurso forjado ou arbitrário; a narrativa anatômica era um caminho a ser trilhado por todos que desejassem a cura oferecida pelos profissionais oficialmente designados para realizá-la.

O corpo daquele que esperasse a cura pelo oficial-anatomista deveria ser entregue ao especialista. Este se prostraria diante do paciente na condição de um estudioso. Interessavalhe o estado dos olhos e seus entornos, se corcovados ou despertos; a condição dos excrementos, se doce ou pastosa, fétida ou saturada de ureia; a umidade da pele, se escamosa, esverdeada ou roxa; a micção e os componentes da urina. Os clínicos apalpavam o abdômen do paciente, encontrando-o inchado ou liso, cheio ou entumecido; ouviam suas queixas; nomeavam seus temperamentos, se coléricos ou sanguíneos, nervosos ou linfáticos.

Produzia-se um corpo à medida que se tratava a doença nele presente. Trilhava-se esse caminho produzindo-se sistemas explicativos para dar conta de sintomas similares. A fisiologia fornecia os parâmetros mais largamente utilizados pelos profissionais que atuavam em hospitais, clínicas, boticas e demais estabelecimentos autorizados a se pronunciarem sobre doenças e curas. Qualquer descrição do funcionamento corporal que não passasse pela fisiologia deveria ser imediatamente banida, pois ameaçaria uma lógica discursiva estabelecida e produtora tanto da doença quanto de sua cura.

De todas as alocuções dos práticos-médicos presentes nos periódicos pesquisados, saltaram aos nossos olhos aquelas relatadas no volume de outubro de 1841 da Revista Médica Brasileira. Naquela edição foram apresentadas suposições acerca de um fenômeno raro e 
indicativo do foco a que se dirigia o olhar médico no momento: um prodígio chamado vagido uterino, no qual se ouviria um gemido emitido pelo feto às vésperas de seu nascimento, quando ele ainda estivesse no ventre materno.

Tal fenômeno, compilado em memória clínica trazida da Bélgica - intitulada Do vagido uterino considerado em suas relações medico-legaes; memória lida a Sociedade das Sciencias Médicas e Naturaes de Bruxellas, na sessão de $1^{o}$ de Julho de 1839; pelo Dr. J. R. Marinus, membro residente, secretario adjunto da Sociedade; traduzida de Bulletin Medical Belge, por J. M. do Rosário (RMB, out. 1841) - permitiu-nos acessar a maneira como as suposições anatômicas se desdobravam no campo enunciativo da medicina, irradiando-se para outros espaços.

A combinação dos sentidos do profissional médico - a audição, o toque no corpo da mãe e do feto e, por fim, a visão - escorava a apresentação das teorizações que então se digladiavam em torno da explicação científica para o acontecimento biológico. Para esmiuçar o dito vagido, reuniu-se uma longa lista de depoimentos de parteiras, acompanhantes e cirurgiões a fim de estabelecer a sequência exata de eventos que levariam ao estranho fato.

$\mathrm{Na}$ tentativa de eliminar o maravilhoso das opiniões, recorrendo a analogias com animais - tais como o pinto dentro do ovo e a vivissecção de animais prenhes - e apoiando-se em dados recolhidos de autópsias, chegou-se a uma conclusão: o som que se ouvia quando o recém-nascido estava prestes a deixar o corpo da mãe só se fazia audível em razão do derramamento do líquido amniótico e do provável rompimento das membranas que o embalavam na placenta antes do parto. Desse modo, explicava-se a prevalência da morte do neonato quando ocorria tal fenômeno, uma vez que, com o rompimento das ditas membranas, acreditava-se que o feto acabava por aspirá-las, sufocando-se e padecendo.

$\mathrm{O}$ inquérito sobre o vagido foi apresentado por meio da análise de nove passos em que o "testemunho de homens tão instruídos deve ser irrecusável" (RMB, 1841, n. 6, p. 336). A alegada aplicabilidade dessa descoberta, além de estabelecer importantes inferências sobre o processo de gestação e nascimento, lançava luz sobre a medicina legal, uma vez que permitiria ao legista comprovar a hipótese de infanticídio quando, na investigação de um suposto crime de aborto, fosse testemunhado o grito do recém-nascido.

O uso do vagido em alegações judiciárias é emblemático para compreendermos a lógica desenvolvida pela anatomoclínica no processo de suas constatações e, por conseguinte, na edificação da autoridade médica. Tal utilidade apoia-se no procedimento, exposto no referido relato, da docimasia pulmonar. Esta se referia a uma experiência que consistia na colocação do recém-nascido falecido em uma banheira com água. Caso a criança boiasse, 
evidenciava-se que ela teria nascido com ar nos pulmões, portanto, com boa probabilidade de ter nascido viva e, em seguida, padecido. Por outro lado, na eventualidade de a criança afundar, supunha-se que o ar já deixara os pulmões e que, provavelmente, o feto morrera ainda no ventre materno.

Havia consequências jurídicas bastante graves na hipótese de infantes natimortos ou mortos ao nascer, as quais envolviam questões sobre herança, donde a suspeita de infanticídio ser uma demanda então considerada. A esse respeito, alegou Dr. J. R. Marinus que, para diminuir as dúvidas no caso da morte de neonatos que emitiram o vagido, a palavra do anatomista seria fundamental, pois a presença de placas das membranas maternas no pulmão do corpo autopsiado indicaria uma suposta contusão proposital da placenta, evidenciando uma intervenção externa com o propósito de assassinato.

Esse intrincado caminho percorrido pelo olhar do anatomista, que estabelece hipóteses, produz significados e chancela decisões, demonstra a ascendência, desde o século XIX no Brasil, dessa expertise sobre o corpo morto. Em nome dela, crimes eram comprovados, valas eram fechadas, cemitérios eram afastados. Tais aconselhamentos sempre foram proferidos do alto de uma autoridade com rara possibilidade de contestação por parte dos leigos.

A manutenção da autoridade médica, dedicada a criar explicações acerca do funcionamento corpóreo e da conseguinte permissão para penetrar com seus ferros o corpo dos indivíduos, precisava, para preponderar, esconjurar os discursos que divergiam da abordagem fisiológica oficialmente estabelecida. Tal foi o caso, entre muitos, do combate ao mesmerismo.

Franz Anton Mesmer teve seu nome ligado à fundação de um princípio terapêutico que os membros da Academia Imperial de Medicina repetidamente associavam ao charlatanismo, qual seja: o magnetismo animal. Atualmente, o mesmerismo é reivindicado por autores que estudam os métodos curativos praticados pela doutrina de Allan Kardec (FIGUEIREDO, 2005). No entanto, quando foi aventado pela primeira vez, na Áustria de 1779, causou grande estardalhaço nos meios médicos. Segundo a memória produzida pelo próprio Mesmer e anexada à obra de Paulo Henrique Figueiredo (2005), o princípio criado pelo eminente médico vienense consistia na aplicação das mãos sobre os doentes para aliviar sintomas, provocando alterações físicas sanadoras em áreas debilitadas do corpo.

Mesmer, na referida memória, defendia seus procedimentos baseando-se na conjectura de que, tal como os astros influenciavam o funcionamento corporal (caso da associação entre as fases da lua e a menstruação), as mãos dos médicos, quando adestradas para transmitir um 
magnetismo considerado natural a toda espécie animal, realizariam curas. O médico vienense sustentava sua argumentação com base no fato segundo o qual "tem-se visto em todos os tempos doenças se agravarem e se curarem com ou sem ajuda da medicina, segundo diferentes sistemas e os métodos mais opostos” (MESMER, 2005, p. 317).

Tal concepção relativista das iniciativas médicas era insuportável para os anatomistas brasileiros. Ao longo de mais de 20 anos, é possível encontrar artigos de membros da Academia Imperial de Medicina versando sobre o tema. Na maior parte deles, os autores recorriam a um histórico da medicina para associar o nome de Mesmer a um personagem descrito como um astuto cientista que, seduzido pelo desejo de notoriedade, acabou por decair da condição de expoente Doutor em Medicina pela Faculdade de Viena para mero propagandista de um engodo.

Em artigo intitulado $O$ charlatanismo - assinado por V. Renouard, alocado na Reveue Medicale Française et E'trangere de abril de 1939, traduzido e publicado em 1841 na Revista Médica Fluminense pelo acadêmico J. M. Rosario (RMF, jan. 1841) -, foi apresentado um histórico da medicina cujo mote era a divisão das iniciativas terapêuticas em dois sentidos: as científicas e outras tidas como imersas na ignorância e proponentes de atalhos da ação médica diante da complexidade em que se apresentavam as queixas e os estados dos doentes.

Para formular a imagem do referido rival, Renouard partiu da Roma Antiga, e, a seguir, historiou a medicina como uma sucessão de sistemas, cuja ilusão imanente teria repousado na tentativa de criar uma solução universal para todos os diagnósticos possíveis. Tal pretensão incluiria o espectro dos "remédios infalíveis" (RMF, jan. 1841, p. 442), cuja permanência teria assombrado a profissão médica desde as práticas da terapêutica romana. Nesse sentido, Renouard destacou ações médicas baseadas em princípios avessos ao cientificismo por ele apregoado. Relatou, por exemplo, o caso do suposto médico da corte britânica João Gaddesden, que, no século XIV, tratara e curara o filho do rei Henrique I da Inglaterra por meio do emprego de panos vermelhos no quarto da criança contra as bexigas que o atazanavam.

Tais descrições, consideradas pseudocientíficas, chegaram a Paracelso, cuja contribuição à medicina foi sintetizada por Renouard como produtora de uma analogia do corpo humano com corpos celestes e como uma busca abnegada pela "quinta essência, o ouro potável a tinctura dos philosofos por meio da qual afiançava, se pode curar todos os males imagináveis" (RMF, jan. 1841, p. 444). Mesmer foi inserido pelo autor nessa ânsia pela detecção e pela cura universais, nessa fé em forças cósmicas, em princípios contrários à 
ciência fisiológica, portanto - particularmente, quando o vienense sugerira o magnetismo animal como um "fluido subtil que enche todo o espaço" (RMF, fev. 1841, p. 473).

Além disso, fato ainda mais condenável pelos anatomistas, o método de Mesmer era criticado pela dependência que o médico deveria estabelecer com os sentimentos de adesão e de bondade, tanto dos pacientes quanto dos curadores. Louis Preisse atribuiu a Mesmer o aforismo segundo o qual, sem "vontade activa para o bem; crença firme no seo poder; confiança inteira” (RMB, fev. 1843, p. 469), seria impossível ao médico tratar seu doente. Dessa forma, o autor atribuiu ao mesmerismo um defeito fulcral: o sistema não permitia ao médico se comprometer em explicar ou mesmo provar seus recursos de cura. Ele deveria basear seus atos e suas justificativas na ação do paciente sobre si próprio e, por conseguinte, deveria ancorar a terapêutica em uma simples relação de confiança.

Associando o mesmerismo às curas medievais, Louis Preisse - traduzido na sessão Revista de alguns jornaes estrangeiros da edição de outubro de 1842 da Revista Médica Brasileira e continuado em 1843 - relevou outro caráter pernicioso do alegado charlatanismo de Mesmer: tal como os curandeiros medievais, o vienense recorria ao segredo para manter uma suposta sabedoria oculta. No entanto, apesar de acreditar feri-la de morte por meio desse argumento, Preisse não confirmou nem rechaçou a doutrina, apenas se restringiu a concordar com os riscos da generalização excessiva de suas práticas.

Em 1853, a Junta de Hygiene Publica veiculou uma resposta ao pedido do acadêmico Dr. Meirelles em relação a uma contenda acerca da manutenção ou da eliminação do Lazareto de Jurujuba, cuja função era isolar os doentes de febre amarela (ABM, jan. 1853). A discussão residiu na determinação das causas das infecções: se contraídas pela ação do ar infectado ou pelo contato direto com os doentes. Dr. Meirelles defendia a eliminação do Lazareto, uma vez que localizava no ar contaminado a razão da enfermidade. No entanto, a Junta não acatou o pedido do ilustre acadêmico. Ao justificar a decisão, argumentou que Dr. Meirelles estava usando um princípio geral para atacar de modo indiscriminado uma gama de moléstias, tal como Mesmer fazia por meio de seu magnetismo.

A condenação ao mesmerismo manteve-se ainda em 1862 (ABM, ago. 1862). Na seção Rápidas considerações, Dr. Nicoláo Joaquim Moreira pronunciou, perante Sua Majestade o Imperador, um discurso Sobre o maravilhoso, o charlatanismo e o exercicio ilegal da medicina e da pharmacia. O autor descreveu Mesmer como um impostor inconsequente que prometera uma panaceia diagnóstico-terapêutica, dando um ar de seita ao conjunto de seus adeptos e criando uma doutrina de impossível comprovação para as suas ações. 
Para Dr. Joaquim dos Remédios Monteiro, o mesmerismo poderia "vegetar apenas na mente das doutrinas fantásticas" (ABM, mar. 1863, p. 244). Incomodava ao referido autor a tina mesmérica ou a baquet, que consistia em uma bacia inventada por Mesmer durante sua estadia em Paris, já que o grande número de adeptos à sua doutrina nessa cidade demandou procedimentos mais dinâmicos para aplicação da terapêutica.

O instrumento era composto por uma bacia em que se instalavam garrafas imersas em água magnetizada pela ação do Dr. Mesmer. Essa água atuava também em barras de ferro que, dispostas no interior do aparelho, recebiam o magnetismo e serviam para aplicá-lo em pacientes que recorriam à terapêutica, dispensando a intervenção direta de Mesmer e otimizando sua ação curativa.

A crítica dirigida por Dr. Joaquim Monteiro centrava-se na suposição de que a cena armada por Mesmer induzia à cura por sugestão, fazendo os pacientes iludirem-se acerca do sucesso da intervenção magnetizadora. O crítico descrevia o ambiente curativo de Mesmer como uma sala plena de pacientes ligados à tina por cordas e expostos a uma suave música, por entre os quais o magnetizador "passeava armado de uma varinha magnética com a qual tocava levemente os indivíduos refractarios" (ABM, mar. 1863, p. 242).

Entretanto, apesar da evidente refutação a uma possível postura místico-charlatã atribuída ao magnetizador, o que mais perturbava Dr. Joaquim Monteiro era a pretensão, atribuída a Mesmer, de atingir com seu método a última perfeição, realizando a plena curabilidade e a evitação completa de toda e qualquer enfermidade.

Outra contestação proferida por Dr. Joaquim Monteiro vinculava-se ao hermetismo do mesmerismo. O sistema instituído pelo médico de Viena parecia ao redator do artigo guardar segredo sobre os fundamentos de suas práticas, fazendo-o associar o magnetizador a um “Grão-Mestre, Vigilante etc., como na Franc-maçònaria" (ABM, mar. 1863, p. 242). Diferentemente da teoria de Hipócrates, cujo mérito teria sido "não passar além dos resultados de suas observações" (ABM, ago. 1862, p. 41), o mesmerismo, segundo os artigos compilados, não poderia ser usado como método de cura, já que, além das numerosas refutações registradas, não demonstrava possibilidade de transmissão de seus procedimentos curativos.

Aparentemente, dito método talvez tenha sido usado como contraponto à comprovação das práticas anatômicas. Os médicos anatomistas pretendiam constituir suas curas à medida que observavam as reações dos pacientes às intervenções. Nenhuma generalização deveria ser possível além daquelas diretamente vinculadas ao funcionamento atribuído aos órgãos, o que dependia sempre do olhar acurado do especialista para a entidade orgânica. Nenhuma teoria 
seria pressuposta, além daquelas que se dirigiam especificamente às alterações do mecanismo orgânico. A figura do médico extrairia sua luz e sua confiabilidade da intervenção direta que realizava, e não da adesão de seus pacientes a uma verdade oculta.

Uma ciência sem nenhuma filosofia. Uma empiria sem nenhum sistema. Um saber prático, produtivo e previdente. Muito distante de representações ou ilusões, a medicina anatômica atrelou diretamente o corpo em funcionamento à vida que deveria ser vivida em seu interior.

Ao longo do século XIX brasileiro, o expert-anatomista foi estabelecendo sua ciência ao longo de sua prática. As relações entre os diferentes órgãos, os líquidos em fruição, a composição do sangue, a eficácia dos procedimentos e a reação aos medicamentos operaram no sentido da formulação de tipos específicos de corporeidade. Corporeidades conformadas pelos ambientes, mas ameaçadas por seus ares danosos; organicidades próprias à espécie, mas portadoras de funcionamentos individuais; individualidades sugestionáveis por charlatães, mas redimíveis pela verdadeira ciência positiva e oficial

A atenção dirigida pela expertise anatomoclínica do século XIX às relações entre o meio social e as fisiologias individuais estabeleceu cânones para a visualização dos corpos. Ao mesmo tempo, operou dentro de uma racionalidade na qual aquilo "que domina a assimilação do organismo a uma sociedade é a idéia da medicação social, a idéia da terapêutica social, a idéia de remédios para os males sociais" (CANGUILHEM, 2005, p. 74).

Desse modo, muito mais do que compreender os enunciados provenientes da fisiologia do século XIX como uma inglória busca pela origem orgânica do funcionamento corpóreo, aventamos, ao lado de Canguilhem (2005), que as alocuções dos fisiologistas retomaram e entronizaram a crença na própria organicidade da natureza. Ademais, ainda com Canguilhem (2006a), quando as práticas discursivas da fisiologia passaram a se debruçar sobre o funcionamento cerebral, esse órgão readquiriu a condição que, desde Platão, localizava-o como "sede das sensações, o órgão dos movimentos e dos juízos” (p. 184).

Entretanto, essa organicidade - conforme as teorizações oitocentistas - regulada pela natureza e suscetível à intervenção terapêutica disparou uma corrente de discursos cujos desdobramentos, desde as teorizações de Franz Joseph Gall - fisiologista fundador da frenologia em 1810 -, "não paravam de falar do alcance de suas teorias na área da pedagogia, da medicina e da segurança" (p. 186).

Abordemos agora outro objeto: a Escola Nova. Dirijamos nossas preocupações à maneira como os discursos provenientes da anatomia e da medicina higienista brasileiras se mantiveram coerentes com suas maneiras de visualizar o corpo, a população, a cidade, suas 
doenças e seus tratamentos. Compreendamos o modo como os escolanovistas incorporaram e reelaboraram tais procedimentos.

Tal como aventado, tomamos como hipótese analítica a suposição da psicopedagogia escolanovista como condição de possibilidade para que os cânones instituídos pelos procedimentos anatômico-higienistas do século XIX, de algum modo, lastreassem as atuais práticas biocientíficas, fundamentalmente naquilo que tange ao anseio pelo aprimoramento da vida psicobiológica. 


\section{Regulação do enfoque: mirada da psicopedagogia escolanovista}

Ambicionando posicionar a Escola Nova na articulação do foco anatômico com as atuais práticas de visualização de corpos, retomemos a narrativa realizada por Clifford Whittingham Beers. Nela encontramos expressa a crença no acesso ao funcionamento mental por meio de um percurso que parte do comportamento socialmente impróprio, transita pelo confino hospitalar, trafega pela interiorização reflexiva e alcança a readequação social.

Como vimos, o olhar previdente dos anatomistas dirigia-se aos corpos doentes e constituía, a partir deles, hipóteses para o funcionamento dos órgãos. Encontramos enfoque parecido no posicionamento do olhar dos psicopedagogos escolanovistas, os quais, em vez de corpos doentes, preocupavam-se com comportamentos inadequados. Em seguida, traçavam critérios para verificar o grau de inadequação, comparando cada um dos indivíduos a seus colegas da mesma faixa etária; supunham, então, vicissitudes nos processos mentais para explicar as inadequações; por fim, estabeleciam ações sobre o meio de forma a garantir a manutenção do bom funcionamento e a eliminação do que era considerado indesejado.

Também Beers trafegou por esse caminho. Reconhecendo a própria insanidade como desequilíbrio mental, sugeriu constituir um meio social capaz de antecipar as causas das alterações na mente. Projeto de caráter fundamentalmente médico, o higienismo mental - cuja difusão pode ser atribuída a Beers - estabeleceu uma inusitada conexão entre corpos individuais e coletivo social. Tal atrelamento envolvia, por um lado, a responsabilização pessoal pelo futuro da civilização e, por outro, insuflava cada cidadão à luta por melhores condições de salubridade para si e para todos os humanos.

Tais foram as bases em que se apoiou a higiene mental. Sobre essa lógica argumentativa foi erigida boa parte da educação moderna no Brasil. Como vimos no capítulo I, a higiene mental foi instituída no Brasil na primeira metade do século XX. Observemos, a seguir, as relações que ela manteve com a nascente Escola Nova nacional.

O movimento brasileiro de higiene mental teve no Brasil um ardoroso defensor: Arthur Ramos. Médico, nascido em Pilar (Alagoas) em 1909, leitor de Levy-Brühl, Adler, Freud e Jung, Ramos produziu extensa obra voltada a discussões sobre a formação da sociedade brasileira à luz da psiquiatria, da psicologia, da antropologia e da psicanálise. 
Em 1934, ele foi nomeado - por interferência de Anísio Teixeira - chefe do Serviço de Ortofrenia e Higiene Mental (SOHM), ${ }^{6}$ ligado ao Instituto de Pesquisas Educacionais do Distrito Federal. A partir dessa experiência, confeccionou a obra A creança problema: $a$ hygiene mental na escola primária (RAMOS, 1939), em que apresenta o resultado de cinco anos de registros dos atendimentos nas clínicas estabelecidas por dito serviço em escolas públicas do Distrito Federal.

A atuação nas clínicas de higiene mental incluía atendimento individualizado das crianças em escolas que faziam parte do programa estabelecido pelo referido serviço. Havia, portanto, instaladas em determinadas escolas do Rio de Janeiro, clínicas para o atendimento de escolares encaminhados por professores, quando o comportamento deles apresentava algum desajustamento preocupante em relação ao dos demais colegas.

Entre as dezenas de casos reproduzidos na obra de Arthur Ramos, vejamos uma interessante cena, na qual se evidenciam um inquérito, uma confissão e uma reparação.

\section{$* * *$}

Em meio aos relatos de Ramos (1939), chama-nos a atenção uma observação feita em um garoto levado ao Serviço em razão de suas permanentes fugas da escola. Na investigação sobre a origem de suas escapadas, notou-se que ele praticava um repulsivo hábito: gostava de fumar maconha.

Conseguia algum dinheiro trabalhando, ora como jornaleiro, ora como pedinte, ora como gatuno, e usava toda a verba na compra da herva. Com suas más companhias, gostava de gazetear as aulas e ficar na rua fazendo arruaças, vagando no centro da cidade - o Distrito Federal brasileiro de 1935. Tinha também outro suspeito hábito: como gostava muito de cinema, assistia com avidez aos incríveis filmes de cowboys e saía pelas calçadas gritando, esbarrando nos colegas, troçando dos amigos, olhando para as meninas.

Em razão de suas constantes fugas da escola, o menino, que então contava 15 anos de idade, precisou depor para o plantonista do SOHM. Respondeu a algumas perguntas, a partir das quais o higienista-redator teceu um relatório para encaminhar ao chefe do serviço. Dizia ele que o garoto era ciente da ilegalidade de seu hábito e se comprometia a seguir a receita apresentada pelo operador do serviço higiênico. Propusera o médico que ele resgatasse seu

\footnotetext{
${ }^{6}$ Órgão ligado ao Instituto de Pesquisas Educacionais, fundado no contexto da reforma do ensino municipal de setembro de 1933. O Serviço começou a operar em 1934 e até 1939 foi chefiado pelo eminente pedagogomédico Arthur Ramos (1903-1949).
} 
crime por meio de um ato reparador: o incriminado deveria entregar ao higienista a porção da herva, caso ainda portasse alguma. O maconheiro-cinéfilo - possivelmente, um sorridente, calmo e distraído rapaz - teve de prometer que levaria, na semana seguinte à entrevista, uma amostra da diamba que comprara do Tutinha, um mulato que o conhecia pelo apelido de Boné-preto.

Não é possível saber o que se deu no restante da vida dos personagens dessa história. Quem seria o rapaz? Quem seria o investigador? Informações hoje impossíveis e desnecessárias. Importa o acontecido, a sequência de averiguações, o encaminhamento do sentido, o deslocamento de forças.

$$
* * *
$$

O caso foi inserido por Arthur Ramos no primeiro capítulo de seu livro, momento em que o autor dedicava-se a dissertar sobre $A$ herança $e$ o ambiente. $\mathrm{O}$ acontecimento do menino maconheiro apareceu no bojo das discussões acerca do jogo entre natureza e cultura. Àquela altura, as teorizações do autor já tinham chegado à suprema tarefa da higiene mental: "estudar os factores culturaes e sociaes que condicionam o comportamento humano" (RAMOS, 1939, p. 11). Por conseguinte, o hábito passava a ser um importante conceito que caminhava em comunhão com o instinto, este sim de origem hereditária, uma vez que diretamente relacionado à maturação orgânica do indivíduo.

Da epopeia do menino maconheiro, destacamos um percurso bastante comum aos demais relatos compilados no SOHM. Após detectada a origem do problema escolar - no caso, a fuga, caracterizada como sintoma pelos higienistas -, procurou-se a origem da máconduta por meio da indução à confissão. Em seguida, conscientizou-se o infante da dimensão do erro para, então, provocar o arrependimento, cujo desdobramento se dava no compromisso com a mudança de hábito.

Outro fator fundamental nos inquéritos higiênicos era a intensidade aplicada à punição/reparação do mau-hábito. A principal contestação que Arthur Ramos dirigia às práticas educativas de seu tempo vinculava-se à extrema severidade com que, até então, pais e professores puniam seus filhos e pupilos. No caso do menino cinéfilo, além da confissão, a punição consistiu na entrega da substância para os responsáveis pelo serviço.

Para garantir o equilíbrio nos procedimentos de confissão e punição, a reeducação higienista precisava extrapolar os muros da escola. Em nome desse objetivo, organizavam-se conferências e mesas-redondas tanto aos pais quanto aos professores, no sentido de minar as 
resistências ao novo projeto. Os motivos alegados por Ramos para que se conscientizassem os envolvidos resumiam-se a duas palavras: narcisismo e scotomismo. Segundo o autor, as duas razões explicavam a aversão às propostas higienistas: de um lado estaria a reserva em modificar as próprias atitudes diante das responsabilidades educativas - ou seja, o narcisismo - e, de outro, a fuga da responsabilização pela origem dos problemas de filhos e alunos - o scotomismo.

Dedicados a afastar os pais dessas duas atitudes perante a criança-problema, os procedimentos higiênicos incluíam eventuais visitas dos higienistas às suas casas para verificar as condições em que os filhos eram criados. No caso dos professores, congressos, feiras e cursos de férias ofereciam esclarecimentos sobre como lidar com os problemáticos na escola.

Nos dizeres de Arthur Ramos (1939), a conscientização sobre as verdadeiras raízes dos problemas dos escolares afloraria com a generalização dos princípios da psicanálise, pois isso ampliaria sobremaneira o leque de alunos abarcados pelos serviços de atendimento psicológico. Tal ampliação foi atribuída pelo autor à distinção que dito saber permitia realizar entre o conceito de criança anormal e de criança problema, distinção por ele tomada como crucial para os planos da higiene mental.

Segundo Ramos (1939), o termo anormal referia-se a uma pequena parte dos alunos que provocavam problemas para os educadores. Tais minorias eram formadas por indivíduos que, submetidos a exames psicotécnicos, neuropsicológicos, médico-orgânicos, neuropsíquicos ou glandulares, teriam recebido, conforme os critérios dessas avaliações, diagnósticos de alguma "cerebrina "constituição delinquencial"” (p. XII) ou de um funcionamento deficitário em algum nível orgânico.

Para os anormais, Ramos sugeria a manutenção da separação em salas especiais ou em institutos especificamente construídos para o atendimento médico de casos graves. Entre estes incluíam-se epiléticos, esquizofrênicos, atrasados mentais e demais deficientes mentais, comportamentais ou motores.

A segregação dos casos anormais, então denominados orthophrenicos, justificava-se, segundo o autor, em razão da necessidade de que esse pequeno número de afetados - perto de $10 \%$ da população de escolares do Rio de Janeiro - tivesse uma atenção médica individualizada e especializada. Desse modo, separados os deficitários e desequilibrados, jazia nas mãos dos higienistas mentais a responsabilidade por todos os demais estudantes entregues à instrução pública. 
No interior dessa maioria, o SOHM voltava especial atenção àqueles cujos professores encaminhavam queixas de incompatibilidade de seus comportamentos com relação ao esperado pelo entorno escolar. Tal encaminhamento desdobrava-se em uma ficha de atendimento cujos dados eram relativos a idade, cor, gênero, nacionalidade dos pais, condição do casal (eventuais separação ou viuvez), profissão parental, condições de habitação (casa alugada ou própria, número de moradores, acomodação de quarto para a criança avaliada etc.), história obstetrícia e parto, vicissitudes no desenvolvimento, alimentação, brincadeiras domésticas e composição fisiológica (presença de doenças como lues congênita, situação das amígdalas, presença de vermes ou anemia etc.), além da performance social e acadêmica na escola. Todas as perguntas e respostas eram realizadas entre os higienistas e os pais, sem a participação dos infantes.

Arthur Ramos utilizou a leitura dessas fichas de avaliação para desenvolver suas concepções acerca das motivações e dos respectivos tratamentos a serem dispensados aos encaminhados. Dividiu suas análises em duas partes, anunciadas como as causas e os problemas.

No campo das causas, ele discriminou seu olhar em direção a: herança e ambiente; $a$ creança mimada; a creança escorraçada; as constelações familiares; o filho único; avós e outros parentes. Quanto aos problemas, Ramos tratou de: a creança turbulenta; tics e rytmias; as fugas escolares; os problemas sexuaes; mêdo e angustia; a pre-delinquencia infantil: a mentira; a pre-delinquencia infantil: os furtos.

Em todos esses momentos, o autor preocupou-se em estabelecer classificações, inserindo causas e problemas em um conjunto graduado de definições que englobassem todos os comportamentos descritos. No que concerne às causas, tal gradação percorreu do mimo ao abandono, com as diferentes intensidades alocadas em situações cuja variação das constelações familiares apresentaria de único filho homem em meio a irmãs, enteados, filhos de viúvas até chegar aos órfãos de pai, de mãe ou de ambos.

A despeito dessas nuanças, todos os problemáticos da escola deveriam ser visualizados em termos de um ajustamento entre a vida doméstica e as exigências da rotina escolar. Aqueles que, sob a ótica dos relatórios das clínicas de higiene mental, eram tidos como turbulentos porque agiam como fanfarrões, tagarelas, agressivos, imitativos, bulhentos, irascíveis, indisciplinados, chorões, beberrões ou fumantes no interior da escola, assim o faziam por estarem acostumados pelos pais e familiares a se comportar desse modo em casa. Da mesma maneira, os pré-delinquentes que agiam com mentira, desconfiança, egoísmo, vadiagem, sedução e descontrole sexual na escola, assim o faziam porque em casa eram 
incorretamente educados. As razões para os comportamentos insuportáveis na escola eram sempre procuradas no convívio familiar, fundamentalmente no triângulo pai-mãe-filho, cujo desequilíbrio instalava complexos e traumas, levando à produção de "atrazados afetivos" (RAMOS, 1939, p. 19).

Partindo da excessiva pressão materna sobre os mimados, até chegar ao desleixo com que eram tratados os escorraçados, o critério de Arthur Ramos para supor as causas e para estabelecer a solução dos consequentes problemas dos escolares passava, invariavelmente, pelo equilíbrio necessário à aplicação da autoridade. Assim, ao atuarem de forma consciente, moral, consequente, saudável e cooperativa, os adultos conseguiriam, na visão higienista, manter ou corrigir os comportamentos das crianças.

Entre as crianças mimadas em diferentes graus e os infantes escorraçados em diversas proporções, estavam todos os educandos suscetíveis à higiene mental. Restaurar ou evitar os desequilíbrios afetivos que atravancavam a vida escolar era tarefa dos higienistas, mas a mudança de atitude deveria, segundo Ramos, partir sempre das famílias. Na quase totalidade das fichas produzidas pelo referido serviço de higiene mental, os aconselhamentos dos especialistas se dirigiam a modificações na rotina da família, fosse o tratamento a um pai alcoólatra, a advertência a uma mãe superprotetora, a eliminação dos castigos físicos, a atenção aos irmãos, a retirada da criança do leito dos pais. Na imensa maioria dos casos, as propostas de tratamento dos alunos-problema conjugavam-se com a recomposição da vida doméstica.

Poderíamos então afirmar que o tipo de conduta exigida no ambiente escolar definia um modo de vida familiar que produzisse atitudes e valores necessários ao bom desempenho dos escolares e, por conseguinte, de toda a sociedade. Tratava-se de um projeto terapêutico no interior do qual a salubridade seria garantida pelo equilíbrio dos afetos, desde que estes fossem mantidos ou corrigidos segundo o acompanhamento diuturno dos escolares.

A problematização dos higienistas, portanto, vasculhava as "atividades instintivas primordiais, como a fome, a sede, as funções de eliminação, o sono e repouso, as atividades de sexo, as principais manifestações emocionais afetivas, o desabrochar da inteligência" (RAMOS, 1939, p. 22), sempre no sentido de oferecer ao analisado referências para a composição de uma história pessoal que justificasse o comportamento problemático.

Portanto, pelas mãos dos higienistas da mente liderados por Arthur Ramos, a psicanálise teria sido convertida em um guia para que os próprios alunos pudessem reconstituir seu passado em busca daquilo que os especialistas consideravam traumas, etapas inconclusas, faltas, fixações e demais desvios. Assim fazendo, os avaliadores-higiênicos 
entrevistavam, observavam, comparavam e relatavam todas as informações por eles consideradas irregularidades no processo de conquista da subjetividade autônoma. À luz de suas leituras de Freud, tais investigadores puderam trilhar caminhos cientificamente orientados em direção ao inconsciente problemático e extrair dele mesmo o processo de sua normalização/libertação.

Não se tratava simplesmente de procurar equivalências entre o indivíduo inadequado e uma personalidade idealizada. A higienização da mente buscava os fatores profundos e subjetivos que desencadeavam os comportamentos indesejáveis com o fito de criar um conjunto de ações para prevenir tais atitudes.

Supomos, então, que a psicanálise, pela via higienista, teria contribuído sobremaneira para alastrar o intervencionismo psi nos tempos da Escola Nova. Por meio da lógica psicanalítica integrada aos procedimentos da psicologia experimental, justificaram-se práticas de autoverificação a fim de garantir a adequação via autonomização; acionando um duplo movimento - externo (sondagens) e interno (racionalização dos próprios atos) -, buscava-se, desse modo, elevar indivíduos problemáticos à condição de sujeitos tratáveis sob os cânones da psicologia amalgamada à pedagogia.

Tratar o indivíduo modificando seu entorno social compunha o projeto da higiene mental. Tal projeto manteve a autoridade dos experts da vida biológica, mas acrescentou a essa vida uma interioridade psíquica que, tal como nos tratamentos das afecções febris do século XIX, poderia também ser tratada por intervenção na exterioridade do corpo.

Dessa forma, aventamos que a higiene mental poderia ter acrescentado um elemento fundamental para a constituição da coeva utopia de aprimoramento humano, nesse caso, propagando a crença na incorporação íntima de práticas vivenciadas no meio social-familiar.

\section{O foco psicopedagógico da Bibliotheca de Educação}

O tema da formulação de uma intimidade no embate com os estímulos exteriores esteve presente também em discursos sanitaristas, civilizatórios, racionalistas, evolucionistas e psicopedagógicos.

Aproximemo-nos desse embate acompanhando as pesquisas de Carlos Monarcha (1999), em cuja obra Escola normal da praça: o lado noturno das luzes pudemos observar a presença do sanitarismo, do civilismo, do racionalismo, do evolucionismo e da psicologia pedagógica nas discussões e nas determinações que envolveram a racionalização científica da 
educação brasileira no contexto de funcionamento e regulamentação da Escola Normal de São Paulo.

Como critério de periodização, Monarcha (1999) utilizou três momentos que corresponderiam às diferentes refundações daquela escola: respectivamente, 1846, 1878 e 1880. Para cada um desses momentos, ele elencou enunciados proferidos por agentes estatais ligados à instrução pública, com o objetivo de mapear as diferentes linhagens do pensamento pedagógico, social, filosófico e psicológico envolvidas na criação de um programa - a princípio regional, posteriormente nacional - de formação de professores.

No primeiro momento narrado por Monarcha (1999), tornam-se evidentes as preocupações dos burocratas coligidos quanto à inserção do Brasil no processo civilizatório, tal como vivido pelo mundo europeu. Dessa maneira, o autor especulou que as ideias pedagógicas apontavam para o estabelecimento de uma educação "moral, intelectual e sentimental” (p. 29). Eliminar os focos de atraso e introduzir o Brasil na corrente civilizatória deveriam compor o núcleo de uma ação pedagógica orientada pelo sanitarismo vigente à época.

A intermitência da Escola Normal de São Paulo no período foi acompanhada por certo refluxo das intensões civilizatórias e pela consequente ascensão de uma fase organicista, cujo núcleo argumentativo localizar-se-ia no uso da metáfora do funcionamento social como um todo orgânico. Dita analogia, vigente a partir de 1870, em 1878 teria se concretizado com a refundação da instituição. A partir dessa ideia, Monarcha (1999) apresentou a implantação, no sistema educativo, dos métodos de uma polícia médica em que estariam contempladas ações tanto no âmbito da urbanidade quanto na área da instrução pública. Tratava-se do "ato de espargir luz” (p. 81) a fim de conter as forças degenerativas do corpo social.

Aos esforços civilizatórios e policialescos teriam sido acrescentados enunciados positivistas, fato concomitante à terceira fundação da escola. As duas décadas finais do século XIX foram descritas por Monarcha (1999) como um contínuo de racionalizações acerca da vida cognitiva, as quais combinariam perspectivas salvacionistas, evolucionistas, objetivistas e naturalistas. Esse processo alcançaria o auge na belle époque, ocasião em que a integração da pedagogia com a fisiologia permitiu a propagação em solo nacional do experimentalismo de Ugo Pizzoli.

Em nossa leitura, o momento-síntese da Escola Normal descrita por Monarcha (1999) seria contemporâneo à presença de Lourenço Filho na instituição. No ano de 1925, o eminente pedagogo assumiu nela o cargo de regente da cadeira de psicologia e pedagogia. Lourenço Filho, segundo Maria Marta de Carvalho (2000), teria sido indicado por Sampaio Doria - 
reformador do ensino paulista desde 1920 - para realizar a reforma educacional no Ceará. Nesse contexto, a autora revisitou, em tal reformismo, as contendas em torno do estatuto da pedagogia moderna.

Assevera ela que, desde a instalação da República, multiplicaram-se tentativas de institucionalizar a escola no Brasil. Assim, nas primeiras décadas do século XX, pode-se observar a afirmação de um modelo pedagógico expresso como arte de ensinar. Os defensores desse modelo reivindicavam as mais atualizadas práticas pedagógicas europeias como escopo para suas inovações. Propugnavam o ensino intuitivo "fundado no princípio de que a educação deveria recapitular, no indivíduo, o processo de evolução da humanidade" (CARVALHO, 2000, p. 115), adotavam as modernas concepções congregadas na psicologia das faculdades e propunham um sistema educacional promotor de uma escola de massas.

Em razão dos princípios bastante próximos aos da Escola Nova, tais educadores foram incorporados, tanto política quanto institucionalmente, pelos reformadores alinhados às teses defendidas por Lourenço Filho. O pedagogo paulista, além de comungar com muitas das teorias desenvolvidas por aqueles educadores, lutava por uma pedagogia científica, em que o experimentalismo justificaria os métodos de ensino e as ciências da educação fundamentalmente a psicologia e a sociologia - garantiriam um amplo programa de produção e difusão de novas e inusitadas ações didáticas no país.

Portanto, fosse por razões políticas, organizacionais ou filosóficas, a reforma paulista de 1920, segundo Carvalho (2000), alcançou hegemonia nos quadros estatais egressos das críticas ao modelo oligárquico da primeira República. A partir daí, segundo Monarcha (1999), a psicotécnica ter-se-ia generalizado e, em virtude disso, os testes psicológicos passariam a ser propalados como componentes de um método rápido, seguro, científico e avançado para a compreensão dos processos envolvidos no aprendizado.

Ademais, nos laboratórios de psicologia experimental, a metáfora orgânica para analisar os corpos social e individual estaria em retração diante do desenvolvimento da analogia maquínica. Dessa maneira, segundo Monarcha (1999), iniciar-se-ia a substituição da seleção natural pela seleção científica. Em nossas suposições, tal ação foi sumamente útil no estabelecimento de um viés terapêutico da escola moderna, uma vez que a natureza agora não seria mais um campo prenhe de acidentes genéticos, mas um espaço aberto à racionalização psicobiológica dos entes alvejados pelos psicopedagogos escolanovistas. Entretanto, como veremos, apesar de decadente na elucidação dos fatores individuais para o aprendizado principalmente com a penetração crescente da psicanálise -, a perspectiva organicista permaneceu em vigor, fundamentalmente a partir das leituras de Durkheim. 
O pináculo do período de modernização escolar teria sido, segundo Monarcha (1999), o ano de 1933, quando se criou a Revista Escola Nova. Nela se teriam combinado alocuções sobre aplicação de testes, elaboração de quadros estatísticos e suposição do desenvolvimento normal com um conjunto de técnicas pedagógicas cujo núcleo partiria do respeito à natureza dos educandos, natureza esta produzida a partir da racionalização filosófica ancorada em resultados aferidos pelos ditos testes.

Tal protagonismo de Lourenço Filho no sucesso da Escola Nova serviu-nos de plataforma para impelir nossas análises sobre o modo como a modernidade escolar brasileira definiu e conduziu aquilo que ela considerou como o corpo psicobiológico infantil no início do século XX. Diante dessas análises, comungamos com Monarcha (2001b, p. 32) a convicção de que a penetração da psicotécnica no ambiente escolar criou condições para se especular que, "aguçando a percepção das tensões contraditórias, a psicologia objetiva irrompe como ciência aplicada à organização da sociedade". A partir daí, voltando o olhar para a individualidade expressa pelos eventos psicológicos e cruzando esse olhar com aconselhamentos dirigidos à reconfiguração social, puderam os experts da visualização psicopedagógica escolanovista estabelecerem os cânones para uma concepção de humano que era, ao mesmo tempo, produzida e vivenciada na escola.

Mergulhemos, então, neste alentado conjunto de obras: uma coleção de livros organizada pelas mãos de Lourenço Filho, cujos exemplares, publicados entre 1927 e 1979, pode nos conectar ao modus operandi da educação moderna brasileira.

\section{A concretude de um livro}

Volume a volume sucede a leitura. Aos poucos se vai tomando contato com a materialidade do objeto gráfico. As capas são bordeadas com austeras folhagens, elementos típicos daqueles tempos modernistas. O nome da obra, de seu autor, seu vínculo institucional e a numeração do volume em romano atestam a celebridade e o posicionamento do exemplar no conjunto da coleção.

1927, 1928, 1929. Abrir uma obra que se manteve em formato de brochura durante décadas inteiras é algo honroso. O frágil objeto, criado com baixo custo, tratava de garantir acesso a amplos setores do professorado brasileiro. A publicação de 137.800 exemplares entre 1927 e 1941 sugere que eles estiveram nas prateleiras de boa parte das escolas normais, das universidades e dos gabinetes do país. 
$\mathrm{Na}$ segunda capa das primeiras edições, vislumbra-se um retrato do autor correspondente: sentado, com ou sem óculos, com ou sem barbas, chalecos para os laboratoristas, olhares expressivos para os filósofos. Entre eles, apenas duas mulheres: Ceição Barreto, Catedrática de Canto na Escola Nacional de Música da Universidade do Brasil, e Isabel Orminda Marques, Professora do Instituto de Educação do Rio de Janeiro, Diretora da Escola Primária do Instituto de Educação.

Folhas enfraquecidas pelo tempo, orthographia de momento, itálicos para estrangeiros e conceitos-chave, pequeno número de páginas, generosa quantidade de subtítulos. Textos claros, objetivos, didáticos e propositivos. Notas de rodapé comprovando a autoridade dos sábios, em completa onisciência racionalista.

Números, quadros, tabelas, enumerações, ilustrações.

O padrão de composição de uma editora comprometida em se tornar um "centro difusor das novas idéias e debates sobre a educação" (DONATO, 1990, p. 82) relevava a simplicidade, mas era intransigente na seriedade. A eminência dos autores e tradutores abrigava diferentes tendências do pensamento educacional mundial.

Hoje, muitas peças já estão em destroços. Algumas delas, abrigadas entre aquelas com circulação restrita e somente acessíveis às benfazejas bibliotecárias. Amarradas com cordões, alijadas das capas originais, abrigadas em pequenas caixas, as obras se deixam corromper à espera do último leitor. Enquanto isso, convertem-se em poeira de livro.

Foi a fim de aproximarmo-nos da expertise escolanovista que estabelecemos como fonte primária os textos compilados na coleção Bibliotheca de Educação. Nas duas décadas ulteriores à instalação da Escola Nova no Brasil, foi muito comum o uso de coleções pedagógicas no processo de formação dos professores. Tais coletâneas teriam substituído os antigos tratados, em volume único, no interior dos quais se encontravam determinações e modelos de práticas abrigadas em exercícios, bem como descrições pormenorizadas de atividades, sempre no intuito de padronizar procedimentos por meio da simplificação de teorias e da eliminação das teses autorais sobre os métodos de ensino (CARVALHO, 2013).

A Companhia Melhoramentos inovou nesse campo: orientou a distribuição e a comercialização da Bibliotheca, sobretudo, para professores em aperfeiçoamento e pais de alunos. A quarta capa dos primeiros volumes esclarece que 
[...] a 'BIBLIOTHECA DE EDUCAÇÃO' se destina a preencher uma necessidade de há muito sentida pelos professores brasileiros, sendo de esperar que ella desperte também, pela agitação das boas idéas sobre o assumpto, tornadas assim mais accessiveis ao grande público, uma literatura nossa de pequenos estudos de iniciação cultural, cujo valor não será preciso encarecer (PROENÇA, 1928, contra-capa).

A missão divulgadora se verifica quando atentamos para o didatismo dos textos, cujos capítulos são curtos, de modo a garantir a precisão e o encadeamento linear das definições. Estas são apresentadas como resultado final das pesquisas de seus autores, demonstrando incontestável compromisso com a formação técnico-pedagógica dos leitores. Ademais, em um estudo sobre a política de preço da coleção, Monarcha (1997) demonstra o caráter absolutamente acessível ao público-alvo definido pela editora.

Afirma Monarcha que a coleção editada por Lourenço Filho pretendeu romper com a lógica dos manuais pedagógicos. A prática de publicar coleções educacionais não foi privilégio da Companhia Melhoramentos de São Paulo. Ao lado dela, entre 1931 e 1981, a Companhia Editora Nacional publicou a coleção Atualidades Pedagógicas, que de 1931 a 1943 contou com a editoria de Fernando de Azevedo. Além das duas, foram editadas: a Coleção Pedagógica (Editora F. Briguet, Rio de Janeiro), a Biblioteca Pedagógica Brasileira (também projeto de Fernando de Azevedo), a coleção Documentos Brasileiros (Editora José Olympio, Rio de Janeiro) e a Biblioteca Histórica Brasileira (Livraria Martins, Rio de Janeiro), entre outras.

A opção pela coleção em lugar dos tradicionais tratados mantinha coerência com os princípios escolanovistas, uma vez que, na composição daquela, não se aspirava criar um conjunto de normas a serem seguidas pelos professores, tal como até então se fazia nos grandes compêndios pedagógicos. Nestes, muitas vezes sem explicitação de autoria, somente se encontravam determinações práticas e exercícios para aulas. Pretendia-se, com as coleções, constituir um apanhado de temas e abordagens que garantissem ao leitor-professor o desenvolvimento de suas próprias soluções, desde que cientificamente orientadas.

A iniciativa de convocar para a editoria autores com eminência teórica e forte atuação na administração pública vinculava-se à pretensão de elevar tais nomes à condição de etiquetas (CARVALHO, 2006) a fim de atrair o público-leitor em direção às suas coleções. O comprador era prioritariamente o Estado, que as dispunha nas instituições de formação de professores.

Lourenço Filho recebeu o convite da Companhia Melhoramentos e, logo no início do projeto, manifestou a intenção clara de proceder à mudança na mentalidade do professorado 
brasileiro. Para tanto, o educador organizou hierarquicamente os volumes com o fito de estabelecer um percurso propositadamente traçado em direção ao que ele considerava plena formação científica dos profissionais-leitores.

Perfazendo o total de 36 títulos, a trajetória da Bibliotheca de Educação pode ser dividida em três fases. A primeira, denominada fase áurea por Monarcha (1997), teria se estendido entre 1927 e 1930, período em que se elencaram 12 títulos cujos autores, expoentes da Escola Nova brasileira e estrangeira, foram escolhidos com base no envolvimento intelectual e institucional com Lourenço Filho. No caso dos autores brasileiros, Firmino Proença e Sampaio Doria possuíam vínculo com o editor em razão da participação na Sociedade de Educação; já Henrique Geenen e Octavio Domingues vinculavam-se a influentes instituições de ensino, tais como o Ginásio de Ribeirão Preto e a Escola Superior de Agricultura Luiz de Queirós, respectivamente (TOLEDO; CARVALHO, 2013).

A opção de Lourenço Filho pela abertura da coleção com volumes sucessivamente de Henri Piéron e Adolpho Ferrière justifica-se pelo fato de o brasileiro, desde o final da década de 1920, ter sido correspondente do Bureau International d'Education, órgão também integrado pelos dois estrangeiros. Quanto ao vínculo com Paul Fauconnet, que assinou o prefácio da obra de Durkheim (volume V), ele se estabeleceu por intermédio do jornal $O$ Estado de São Paulo, que em 1932 publicara o Manifesto dos Pioneiros da Educação Nova, iniciativa a que o autor francês esteve ligado por fazer parte do Grupo Francês da Educação Nova.

Por fim, os dois autores norte-americanos William Kilpatrick e John Dewey tiveram suas obras publicadas devido à recomendação de Anísio Teixeira, que se encantara com o trabalho realizado na Universidade de Columbia. Anísio participou ativamente das intermediações que levaram à autorização, à elaboração e à publicação da obra Vida $e$ educação, uma reunião de dois escritos de Dewey: A criança e o interesse escolar e Interesse e esforço.

Na fase áurea da Bibliotheca de Educação, os autores dos volumes, assim como os tradutores, foram entronados como grandes nomes da educação mundial, imprimindo "às obras um tom alto e oficial” (MONARCHA, 1997, p. 40). Entre as instituições a que se ligavam, destacam-se órgãos estrangeiros como o Instituto Jean-Jacques Rousseau, a Universidade Sorbonne, a Revista Pedagógica (espanhola) e a Universidade de Columbia.

Quanto às reedições e tiragens dessa primeira fase, a obra de Piéron ([1927]) teve duas edições, assim como a de Binet/Simon (1929). Os números aumentam quando consideramos as obras de Durkheim ([1929]), com 12 edições; de Dewey (1930/1952), com 11 edições; e de 
Lourenço Filho, com 13 edições. As reedições chegaram a perfazer um total de mais 195.000 de tiragens no total da coleção (MONARCHA, 1997).

A segunda fase de publicação da Bibliotheca de Educação corresponde ao período entre 1931 e 1941, definido por Monarcha (1997, p. 30) como "fase de rotinização e ampliação da representatividade do projeto educacional". À época, segundo Carvalho e Toledo (2006), Lourenço Filho passou a implementar planos para nacionalizar suas iniciativas voltadas à formação de professores. Tal fato articula-se à presença do reformador na Associação Brasileira de Educação e à sua consequente aproximação com a intelectualidade do Rio de Janeiro, onde travou contato com Venancio Filho, Jonathas Serrano, Ariosto Espinheiro, Teixeira de Freiras, entre outros. As maiores tiragens e edições dessa fase foram da obra de Kilpatrick ([1933]), com 16 edições e 74.100 exemplares; Testes ABC, de Lourenço Filho, teve 12 edições e 62.000 exemplares (MONARCHA, 1997).

Na terceira fase, entre os anos de 1941 e 1979, o projeto editorial perdeu o sentido que até então preservara, tendo-se optado pelo abandono da sequência de volumes. Na década de 1940, cinco títulos tiveram reedições: as três obras de Lourenço Filho, a de Piéron e a de Abner de Moura. Na década de 1950, Dewey, Durkheim e Kilpatrick foram acrescentados a novas reedições dos textos de Lourenço Filho. Nos anos de 1950 e 1960, ocorreu um desmembramento com a publicação das Obras completas de Lourenço Filho. Ademais, iniciou-se naquela época outro desmembramento, com a criação das séries Grandes Textos e Iniciação e Debate. Mesmo após a morte de Lourenço Filho, em 1970, a coleção continuou a ser publicada, mas sem a linha editorial que existira até a década de 1940 (CARVALHO; TOLEDO, 2006; CARVALHO, 2013), razão pela qual essa fase está ausente da presente pesquisa.

O processo de criação da coleção relaciona as obras a um princípio comum: instruir os professores no que tange às descobertas científicas de então e, por conseguinte, iluminar suas práticas pedagógicas. Portanto, o destaque que concedemos à Bibliotheca de Educação acompanha a linha editorial que contempla a proeminência de seu editor, tanto na escolha quanto no alinhamento das obras.

Lourenço Filho foi um importante reformista brasileiro que teve o mérito de ter introduzido no Brasil o primeiro laboratório de psicologia experimental. Também participou da reforma educacional do Ceará, em 1922; foi docente de psicologia e pedagogia na Escola Normal de São Paulo, em 1924; dirigiu a Revista de Educação e figurou em diferentes cargos da administração varguista durante a década de 1930. 
A organização da Bibliotheca de Educação marcou, pois, o projeto de um dos mais influentes promotores da Escola Nova no Brasil. Analisá-la-emos tendo esse aspecto em vista, tratando os textos compilados por Lourenço Filho como a produção de determinada concepção de educação. Contudo, ressaltamos que tal concepção esteve sempre atrelada a cânones específicos de visualização do humano, e é nesses cânones que pretendemos nos concentrar, sem desprezar, evidentemente, os critérios de produção e circulação dos enunciados. Assim, tomaremos a Bibliotheca de Educação como plataforma para vislumbrarmos o discurso performativo dirigido a uma forma de subjetividade que hoje chamamos de educando moderno.

O procedimento escolhido para o manuseio da dita coleção obedece ao espírito de sua produção, de modo que adotamos a mesma sequência criada pelo editor, percorrendo os volumes sucessivamente. Apenas uma exceção haverá nessa ordem: iniciaremos a análise pelo volume Introdução aos estudos da escola nova, publicado em 1930, no $11^{\circ}$ volume. A estratégia vincula-se ao fato de que, na citada obra, Lourenço Filho apresenta suas próprias concepções acerca do escolanovismo e, por conseguinte, enuncia suas perspectivas pedagógicas. Ao iniciar pelas teorizações do editor, visamos compreendê-las como um índice a partir do qual se organizaria uma perspectiva possível para se visualizar o humano produzido por um ângulo específico da educação reformada.

Em Introdução ao Estudo da Escola Nova, o infante tornado visível por Lourenço Filho ([1930]) pertence a um estágio de evolução anterior ao do adulto. As crianças são descritas como seres desprotegidos; comparáveis aos animais e aos humanos selvagens, elas adquiririam progressivamente a linguagem, depois o pensamento, até se formarem como "homens de iniciativa e capazes de governarem-se a si mesmos" (p. 208). Do mesmo modo que a criança se desenvolve em direção ao adulto, os conhecimentos científicos também evoluiriam, sendo seu ponto de chegada a plena integração da fisiologia à psicologia.

Ciência e humanidade contra animalidade e selvageria: a fórmula, segundo o autor, só foi pensável após a tragédia experimentada durante a Primeira Guerra Mundial. Na ocasião, teria se tornado evidente à percepção de todos a impossibilidade de se restaurar a antiga humanidade. A solução seria, portanto, voltar os olhos para a criança, esta a ser reencontrada na condição da "lympha pura" (p. 2) a partir da qual o homem poderia iniciar toda a renovação vindoura.

Assim, se a criança seria o futuro da humanidade e a ciência o caminho para que o futuro surgisse sem a pecha da selvageria, a escola deveria estar cientificamente lastreada para que os responsáveis pela transformação do mundo pudessem controlar a consecução de seus 
planos. A ciência, em permanente evolução, teria atingido, nos tempos da Escola Nova, a garantia para a completa compreensão do humano e, por extensão, conseguido reunir os meios para modificar o comportamento infantil em direção aos fins pretendidos, que incluíam a criação de uma sociabilidade produtiva e pacífica. Os referidos meios residiriam na compreensão da vida psicológica dos infantes, estando os fins a cargo dos mentores filosóficos e sociológicos da humanidade.

Tal ser incompleto, portador da esperança de futuro e maleável, segundo o eminente reformador, seria um ente biologicamente reconhecível. Herdeiro de uma ancestralidade que remontaria há pelo menos "cento e cincoenta anos antes do seu nascimento", deveria ser respeitado em sua configuração preconcebida/hereditária, de modo que o ensino se ocupasse da "defesa da saúde dos escolares, da adaptação dos processos e andamento do ensino á sua capacidade vital" (p. 14).

O progresso observado no desenvolvimento psicobiológico e sociofilosófico também foi aventado por Lourenço Filho em termos de sistemas educacionais. Superar-se-ia a antiga escola, na qual o ensino mnemônico, a coação e a centralização no mestre das ações educativas eram os fundamentos daqueles tempos passados. A humanidade estaria em busca de um ensino ativo, em que a liberdade e o protagonismo juvenil substituiriam as velhas práticas segundo as quais a escola não mais prepararia para a vida, mas deveria "ser a própria vida" (p. 65).

Destarte, atualizando as mais avançadas pesquisas científicas de seu tempo, Lourenço Filho ([1930], p. 75) condensou suas pretensões pedagógicas na máxima: “educar é a arte suprema de modelar os homens para uma vida melhor”. É perceptível que a novidade ambicionada pelo autor comungava com um tipo de sociedade cujos fundamentos seriam inoculados nos mais jovens. Mas atentemos: tratar-se-ia de uma inoculação desejada e possível, pois teria como fundamentos somente aquilo que os estudantes fossem capazes de adquirir, sendo a capacidade aferida conforme a performance obtida nos exames.

Lourenço Filho ([1930]) planejou que o ensino renovado deveria consistir em uma intervenção educativa que partisse da compreensão científica da natureza do educando e nela sustentasse a produção de um cidadão. Por isso:

A coleção toda se dividirá em duas series. Na primeira, de caracter geral, serão expostas bases scientificas do ensino, já do ponto de vista genético funccional da sua organisação, já do ponto de vista da finalidade social e moral a que deve tender a elevação do homem, como cidadão e como homem. Na segunda, serão examinados os meios práticos de educação e ensino, tratando-se de modo particular das aplicações que mais nos 
convenham, com indicações e crítica de sistemas (LOURENÇO FILHO, 1927, p. 4).

Ao repararmos na sequência de volumes efetivamente realizada, apercebemo-nos de que a intenção não foi cumprida da maneira planejada. Até o volume VI, a coleção trafegou pelas enunciadas bases científicas do aprendizado; porém, como se verá, a partir do volume VII, a sequência não se manteve na estrutura anunciada e sucederam-se volumes carregados de teorias científicas combinados com obras voltadas à aplicação prática. Mesmo assim, optamos por seguir o roteiro definido na apresentação da coleção e agrupamos os volumes segundo a ordem numérica estabelecida pelo editor, pois, evidentemente, nem sempre os autores dos volumes cumpriram as intenções do editor, muitas vezes não se atendo aos fundamentos científicos ou aos meios práticos. Além disso, aceitamos a prerrogativa do organizador da coleção, uma vez que pretendemos sopesar o permanente, ocasional e arbitrário jogo entre saberes e fazeres no que tange às narrativas psicopedagógicas acerca da natureza do infante.

Tal natureza, embora pudesse ser reconhecida pelo costume e pela intuição dos professores - ambos princípios da pregressa escola tradicional repudiados por Lourenço Filho -, sempre guardaria espaço para a emergência de "indivíduos, com natureza objectiva, exteriores em relação a nós, oferecendo-nos reações diversas que ferem os nossos sentidos, e que podemos assim estudar e interpretar, classificar e predeterminar" (LOURENÇO FILHO, 1927, p. 6).

Estudo, classificação, predeterminação e respeito à individualidade. Segundo Lourenço Filho, esses seriam os princípios a partir dos quais toda renovação escolar seria possível. Tais intentos e procedimentos justificariam a imersão do reformador nas conceituações provenientes da psicologia experimental.

Henri Piéron foi o autor escolhido pelo editor para que se iniciasse o estudo das bases científicas do aprendizado. Em 1912, Piéron sucedeu Alfred Binet na direção do Laboratório de Psicologia Fisiológica da Sorbonne. Em 1921, fundou o Instituto de Psicologia da Universidade de Paris, tendo atuado, ao longo de toda a vida, pela institucionalização da psicologia francesa. Iniciou sua obra Psychologia experimental apresentando o modo como a referida ciência encaminhara uma questão presente na ciência moderna desde há muito, qual seja: a ação do medidor - ou, nas palavras do autor, a "equação pessoal" (PIÉRON, [1927], p. 11) do avaliador - diante dos procedimentos por ele aplicados. Tal problema teria sido resolvido por máquinas tidas como "registradores automáticos" (p. 11). 
No interior desses registros, muitas ações corpóreas poderiam ser alvo de medição. Entre elas, Piéron ([1927]) escolheu analisar as diferenças entre a fotometria e a sensibilidade visual. A fotometria seria, segundo o autor, um procedimento dominado pelos físicos; por meio dela, detectar-se-ia a variação da intensidade da luz quando encontrasse o olho humano. A sensibilidade visual, por outro lado, diria respeito a um campo enunciativo diverso; ela seria descrita pela capacidade individual de percepção da luz, ou seja, uma dimensão pessoal/psíquica. $\mathrm{O}$ autor demonstrou que, ao instituir padrões avaliativos para os dois grupos de fenômenos - físicos e psíquicos - e fundi-los em uma única apreciação, estar-se-ia aplicando a técnica de uma ciência profundamente atualizada e objetiva: a psicofísica, campo em que os registros poderiam ser realizados por meio de máquinas, sem a intervenção desviante do aplicador humano.

O caminho trilhado pela psicofísica garantiria o acesso objetivo ao funcionamento do corpo a ser conhecido. Ao se debruçar sobre as reações do avaliado diante de estímulos previamente calibrados, esperava-se encontrar "a chave das funções sensoriaes e cerebrais" (p. 12). Desse modo, partindo dos cânones de ciências como a física, à época reconhecida por sua objetividade, e aferindo as reações dos avaliados diante das excitações padronizadas, os psicólogos experimentais estabeleciam critérios para medir variadas instâncias que, segundo suas teorizações, relacionavam-se com o aprendizado.

Portanto, definiram-se as percepções infantis que apresentavam condições técnicas de serem avaliadas e, concomitantemente, os exames que as avaliariam. Foi então possível avaliar: o limiar das sensações (excitando-se os aparelhos sensoriais corpóreos); os limites entre percepção e ilusão; a "dysposição typographica optima dos textos, destinada a facilitar a leitura" (p. 32); o nível de percepção tátil e cinestésica (do movimento); a percepção do relevo e do tempo; a velocidade das reações; a precisão motora; o reflexo condicionado; a influência “das sensações, emoções, representações mentais diversas, e especialmente a do esforço, da volição dynamica" (p. 47) na força das reações; a atenção, a distração e a inibição; o esforço mental e a fadiga; a memória; "a duração do presente mental” (p. 52); os esquecimentos; as leis do hábito; o tempo das reações associativas, a eletividade das associações; os "fenômenos electivos de reforço e inhibição" (p. 53); a introspecção e a consequente produção de imagens.

$\mathrm{Na}$ medida em que se definiam instrumentos para aferir as reações dos músculos e nervos diante de excitações previamente calibradas, definiam-se também as funções corpóreas necessárias para a realização da aprendizagem.

Muito além de apenas criar padrões objetivos a serem medidos por uma suposta arbitrariedade instituída pelo cientista, a prática da psicologia experimental oferecida por 
Piéron ([1927)] estabeleceu as supracitadas funções perceptivas como fundamentos orgânicos para a aprendizagem. A partir daí, torna-se compreensível que Lourenço Filho inaugurasse sua coleção com o referido livro, pois, após a sistematização oferecida pela psicologia experimental, dificilmente a cultura escolar abdicaria de associar aprendizado a percepção, sensação, ilusão, leitura, representação mental, atenção, esforço, fadiga, introspecção etc., sempre tomando tais associações como cânones para visualizar processos vitais dos corpos em desenvolvimento.

Além disso, o que fascinava o editor eram as possibilidades oferecidas pelos testes. Piéron ([1927]) os apresentou em termos de sucessão de tentativas e refinamentos na busca de objetividade. Nesse trajeto, alguns processos corporais foram eleitos como fundamentos para uma eficaz adequação dos indivíduos a determinadas funções sociais. Os avaliadores elencados pelo autor teriam persistentemente instalado provas, com maior ou menor facilidade de aplicação, a partir das quais pudessem extrair dos avaliados respostas passíveis a uma posterior tabulação. Ao fazê-lo, entronizavam a ideia de que, além de separar resultados dentro ou fora da normalidade, poderiam estabelecer tipos psicológicos, cujos nível e physionomia mental garantiriam tanto a correta estimulação educativa quanto a expectativa diante do resultado a ser alcançado pelo educando. Tratava-se, então, de orientar o ensino para a realização da "escola sob medida" (p. 129), tal como apontava Edouard-Jean Alfred Claparède.

A concepção de ensino sob medida fundamentou, segundo o editor, a escolha do segundo volume da Bibliotheca de Educação. A obra intitulada A escola e a psychologia experimental foi realizada em 1916 por Claparède, que, desde 1908, era professor de psicologia na Universidade de Genebra (ARCE; SIMÃO, 2007). Nela, o autor apresentou suas ideias acerca de um modelo escolar em que a centralidade absoluta do esforço pedagógico deveria estar na criança.

A escola sob medida seria, conforme Claparède, um ambiente de absoluta socialização, livre de toda coerção por parte dos mestres e profundamente interessante, cujas atividades estariam voltadas ao correto desenvolvimento do educando, dispensando-o da fadiga presente em recintos educacionais que desprezavam a natureza infantil. O acesso a essa natureza seria tangível a quaisquer profissionais-educadores. Bastaria adquirir conhecimentos acerca dos processos mentais, que se sofisticariam segundo a sucessão das idades, em seguida preocupar-se em instituir o hábito de trabalho e, por fim, respeitar os processos vividos no interior de cada individualidade. 
A criança visualizada por Claparède ([1928], p. 19), além de sociável, livre e potencialmente interessada, também possuía estruturas mentais entre as quais o "instinto de brincar" constituía-se no principal núcleo. A partir de tal inatismo brincante, o autor ergue todo o edifício científico que deslinda a natureza desse ser, ao mesmo tempo ativo e condutível. Tal condução adviria caso o professor, devidamente paramentado pelas teorizações psicológicas, conseguisse adequar suas atividades aos desejos de seus pupilos.

A base para o sucesso na aplicação das atividades procederia do uso de técnicas cientificamente escoradas, que deveriam respeitar a essencialidade do processo de aprendizagem. $\mathrm{O}$ autor apresenta como elementos desse processo: a memória; os procedimentos de leitura; as diferenças individuaes e os typos mentaes; a idade e o desenvolvimento; o sexo; as variações da energia mental ao longo do dia; a fadiga; a influencia collectiva; as emoções; a cultura formal; a personalidade do professor.

Mais uma vez, tal como nas acepções de Piéron, a cada um dos fatores constituintes da cognição corresponderia uma bateria de testes capazes de precisar objetivamente o nível em que se encontrava cada uma das individualidades. Individualidades livres, interessadas, brincalhonas, ativas e naturalmente propensas a frequentar escolas no interior das quais confrontariam seus desejos pessoais tanto com as determinações dos professores quanto com as naturais propensões de seus colegas.

Segundo Lourenço Filho, Claparède, nesse livro, teria sintetizado alguns dos fundamentos da Escola Nova. Ao apresentar a "educação como um esforço em prol da socialização da criança” (LOURENÇO FILHO, 1928, p. 5), sugeria que a natureza livre de cada um deles deveria ser conduzida em direção à coletividade da qual faziam parte.

Assim como nas narrativas de Piéron, a visualização estabelecida por Claparède observa a exterioridade do comportamento com vistas à interioridade das estruturas mentais. Ambos partiram de uma alegada liberdade natural e chegaram à physionomia mental. Para os dois autores, seria indiscernível a vida social da individualidade psíquica.

Imerso nesse embate entre individualidade e coletividade e considerando a socialização do infante como a mais alta prioridade da escola, Lourenço Filho convocou Antonio de Sampaio Doria para dissertar sobre o tema. Sampaio Doria, profundamente envolvido no espírito reformista da década de 1920, fora Diretor Geral da Instrução Pública do Estado de São Paulo, lente de psicologia na Escola Normal de São Paulo e professor da Faculdade de Direito de São Paulo. Militante da Liga Nacionalista e republicano abnegado, ele esteve presente nas principais contendas políticas pós-Primeira Guerra Mundial e na consequente desmontagem do modelo oligárquico brasileiro (MATHIESON, 2012). 
Apesar de sua atuação no campo da pedagogia partir da psicologia, Lourenço Filho encomendou a Doria uma obra sobre educação moral. No terceiro volume da coleção Bibliotheca de Educação, intitulado Educação Moral e Educação Econômica, Sampaio Doria ([1928]) apresentou uma composição das teorias da psique com suas concepções acerca da organização social, dentre as quais se destacava sua militância civilista (CARVALHO, 2013).

$\mathrm{Da}$ intersecção entre psicologia e sociologia configuraram-se temas fundamentais à caracterização do aprendiz e de seu aprendizado naqueles tempos reformistas. O livro assinado por Doria ([1928]), ao dissertar sobre a moral, enfoca três elementos que, em sua opinião, deveriam ser apropriados pelo aprendiz no processo de sua educação: a liberdade, a consciência e a responsabilidade. Um ser livre seria, conforme o autor, um indivíduo capaz de "firmar o hábito de resolver-se por si mesmo" (p. 17). A postura autônoma garantiria a conquista da consciência por meio de atitudes de quem se responsabiliza pelas “consequências de seus atos e omissões" (p. 19).

Nas escolas, o cultivo da moral deveria priorizar a "educação da vontade" (p. 29). Esta conduziria os aprendizes ao exercício de uma sensibilidade capaz de evitar os erros, assumir as culpas e condescender com as penas. No caminho de uma educação moral, os professores deveriam estimular a autoconfiança de seus alunos, habituando-os a decisões responsáveis. Ao longo desse processo educativo, o peso da autonomia deveria crescer à medida que diminuiria o peso das ordens dos adultos.

Autônomo, consciente e responsável, o cidadão descrito por Doria ([1928], p. 43) deveria aceitar seu papel na natureza, esta "eterna mestra da verdade" que obrigaria a todos os humanos à responsabilidade physiologica, qual seja: a conservação, em estado normal, dos corpos individuais e, por conseguinte, do corpo social. Tal postura responsável adviria quando a inteligência - desenvolvida por meio de exercícios cientificamente controlados - superasse a vontade. Residiria aí o papel fundamental da psicologia e da escola.

A psicologia elucidaria os meios pelos quais os educandos aprendem e se desenvolvem. Seu mote seria promover a conquista do equilíbrio mental necessário, por meio do qual o aluno pudesse desenvolver uma faculdade do esforço condizente com a inibição dos instintos, que sempre se apresentariam mais fortes em relação às manifestações da inteligência humana. Já a educação, aplicando corretamente esses meios, garantiria o aprimoramento de hábitos suficientemente robustos para guindar os aprendizes à condição de cidadãos produtivos e civilizados.

Assim, o aprendiz estaria apto a viver segundo o cultivo do "hábito do bem e o horror do mal” (p. 17), entendendo-se por bem tudo aquilo que estivesse em consonância com a 
natureza humana e por mal tudo aquilo que se aproximasse do egoísmo e do autoritarismo. Tais ações estariam em conformidade com a crença no educando como "entidade biopsychica" (p. 7), capaz de viver sob o princípio de que a obediência social faria parte da natureza humana. Portanto, "nos que já transpuseram os trinta anos de edade, é quase inútil tentar reformas" (p. 79). Seria então atribuída a condição de antinatural ao ente que não conseguisse, após o aprendizado, controlar a vontade e atuar socialmente.

Destarte, segundo Doria, uma educação propriamente moral justificaria o rigor das punições no caso das agressões à liberdade; no caso das anomalias diante da natureza, justificar-se-ia a eugenia. Ainda no que se refere às bases psicobiológicas nas quais se deveriam assentar as propostas dirigidas a um ensino sob medida, vemos despontar a referida responsabilidade physiologica, ou seja, uma ação do aprendiz para consigo mesmo no sentido de racionalizar suas vontades e afastar-se da imoralidade.

A relevância da fisiologia individual na composição social também foi assunto abordado no quarto volume da coleção. Henrique Geenen - apresentado como professor do Ginásio de Ribeirão Preto era também docente de psicologia, historiador e romancista - foi convocado por Lourenço Filho para dissertar sobre as principais teorias da psicologia no campo das relações entre fisiologia e comportamento. Assim, na obra Temperamento $e$ caracter sob o ponto de vista educativo, Geenen ([1929]) fez uma compilação de autores que se dedicaram às distinções entre os caracteres hereditários e os caracteres adquiridos na composição da vida psíquica.

Considerando que a educação deveria ter papel destacado na aceleração e na sofisticação do desenvolvimento dos educandos, Geenen ([1929], p. 7) observou que a tarefa educativa seria a da "apresentação da cultura dada pelos membros adultos de uma sociedade a seus membros mais novos". Segundo ele, portanto, a educação deveria ser realizada tal como a ação de um horticultor cuidadoso que poda a exuberante copa das árvores "para que seu viço não prejudique a maturação dos fructos" (p. 7).

Visando uma educação consciente e acertada, o educador deveria conhecer o jogo entre a base biológico-hereditária e suas transformações mediante as experiências provenientes da atuação social dos educandos. Nesse sentido, Geenen ([1929], p. 13) definiu o temperamento como a "individualidade physica, e que serve de alicerce sobre que se desenvolve o caracter".

O autor localizou no sistema nervoso dita base biológico-hereditária. Assim, trafegou por diferentes teorias que o fizeram concluir que "nossa personalidade é reflexo do nosso organismo" (p. 20). Entre tais teorias, ele deu destaque àquelas que ambicionavam encontrar a 
localização encefálica de diversos comportamentos e funções, tais como afetos, memória, percepção e raciocínio, sempre comparando cérebros aparentemente ilesos com outros afetados por toxinas ou más-formações. Geenen ([1929], p. 30), enfim, definiu o cérebro como o órgão responsável por guardar a "a memoria da espécie".

Após reconhecer o homem-espécie, o autor passou a discorrer sobre o elemento individual no humano, qual seja: o temperamento, configurado a partir da resposta pessoal e dinâmica às impressões externas. Geenen ([1929]) deu especial relevo às classificações de temperamento apresentadas por numerosos autores peritos no rico tema. Tais classificações apresentaram-se, na pena do autor, como o caminho mais seguro para a orientação do professor diante da diversidade de tipos psicológicos apresentados pelos seus alunos.

Nas classificações expostas por ele, pode-se encontrar um elemento comum. Todas elas estabeleciam uma graduação entre personalidades psicóticas e a normalidade de determinado temperamento. Nesse sentido, o autor apresentou sua classificação de temperamentos com base no critério das constituições: paranoica, perversa, mitomaníaca, ciclotímica hiperemotiva - as quais, no limite, tendiam a uma psicose, mas, em graduações suportáveis, demonstravam apenas propensões temperamentais.

Outro exemplo representativo descrito em detalhes por Geenen ([1929]) tratou-se da classificação de Boll e Delmas, a partir da qual o autor compilou a enunciação de um typo.

[...] o typo "intrigante" é assim representado: $\mathrm{E}=0 ; \mathrm{V}=+2 ; \mathrm{B}=-1 ; \mathrm{S}=+3$; $\mathrm{A}=+1$. Fórmula que devemos ler: no intrigante $\mathrm{E}$, a emotividade é nulla; $\mathrm{V}$ a avidez é positiva, forte; $\mathrm{B}$, a bondade é negativa, grau fraco; $\mathrm{S}$, a sociabilidade é extrema. A, a actividade, é positiva, grau fraco (p. 60).

A álgebra biológica da dupla de cientistas definiu oito elementos que poderiam estar presentes em sete graus diferentes, resultando em 5.764.801 caráteres possíveis. A absoluta abrangência que o resultado da álgebra biológica apresentava não inviabilizou, para Geenen ([1929]), a certeza na objetividade do procedimento classificatório. Antes ainda, a imensa quantidade de possibilidades permitiu, segundo ele, que as especificidades individuais aparecessem com mais força, já que por meio desse procedimento aflorariam milhões de possibilidades para que as idiossincrasias pessoais fossem inseridas em alguma específica categorização de temperamento.

Destarte, as manifestações pessoais perderiam quase completamente a particularidade. No interior dessa lógica discursiva, praticamente nenhum comportamento apresentar-se-ia inusitado, uma vez que sua ancoragem na organicidade atribuída ao corpo humano projetava a esperança de que a expansão ilimitada dos conhecimentos sobre a fisiologia e a genética garantiria, em algum futuro, a explicação para a totalidade das condutas próprias da espécie. 
Contudo, além das incursões pelas teorias psicológicas, fisiológicas e genéticas, Geenen ([1929]) evocou um raciocínio, recorrente no pensamento educacional moderno, cujo âmago ancorava-se no pareamento entre a ontogênese e a filogênese.

O individuo humano, nos primeiros mezes de sua vida, quando é criança de peito e que nelle preponderam os sentidos inferiores, a vida surda dos impulsos e dos reflexos, acha-se no estado de mammifero. Na segunda metade do primeiro anno, com a actividade de apanhar e de imitar tudo, alcança o estado dos macacos anthopoides superiores. No segundo anno, por meio do andar erecto e da linguagem, chega ao estado do homem propriamente dito. Nos cinco annos seguintes, na idade dos brinquedos, dos contos phantasticos, acha-se no estado dos homens primitivos. Só em seguida, pela frequencia da escola, vem a incorporação ao meio social com os deveres rigorosos, a distincção entre a ociosidade e o trabalho (p. 73).

A humanização, portanto, seria um processo natural que repetiria a própria evolução das espécies animais. Desse modo, a identificação da criança com mamíferos primitivos permitiria duas ações: primeiramente, viabilizaria a pesquisa dos comportamentos de animais para supor as etapas de desenvolvimento da vida humana; por outro lado, também possibilitaria estudar sociedades que, no presente, ainda estivessem em estágios préhistóricos, no sentido de suas características permitirem analogias com fases da sociabilidade infantil. Tal approach desenvolvimentista, enfim, demonstraria o papel da educação na intensificação do progresso em direção à humanização plena pela via da socialização.

Em nosso entendimento, a atenção aos binômios estímulo-resposta, individualcoletivo, vontade-esforço, hereditário-adquirido, infantil-adulto e desenvolvimento-evolução, presentes em Piéron, Claparède, Doria e Geenen, sustentou a lógica em que Lourenço Filho apoiou sua ambição de racionalizar as relações educativas. Tal racionalização deveria ser capaz de instrumentalizar cada um dos indivíduos segundo suas potencialidades, a fim de assegurar o convívio com seu meio social de maneira que a adequação pessoal ao coletivo garantisse, impreterivelmente, o desabrochar natural de sua condição de humano.

Se essa análise fosse correta, ela bem poderia justificar a presença da obra de Émile Durkheim, Educação e sociologia, ${ }^{7}$ no quinto volume da Bibliotheca de Educação. Tal como discorreu na introdução ao texto, Paul Fauconnet ([1929], p. 7) considerou que, segundo Durkheim, o jogo entre o ser individual e o ser social explicaria por si só toda "a obra da educação".

\footnotetext{
${ }^{7}$ A obra Educação e sociologia foi publicada em 1929, no quinto volume da coleção Bibliotheca de educação. Falecido em 1917, Durkheim teria confeccionado os textos que compõem a compilação entre 1903 e 1911, os quais teriam sido editados postumamente, em 1922 (DIAS, 1990).
} 
Embora tal jogo individual/social não fosse tomado como dicotômico, na visão de Fauconnet ([1929]) ele seria indispensável para discernir aquilo que Durkheim estabeleceu como os meios e os fins da educação. A esse respeito, o prefaciador insinuou que os meios seriam aqueles tangenciáveis pela psicologia, sendo os fins aqueles instituídos pela pedagogia.

Para ele, os caracteres psicológicos da criança, na visão de Durkheim, seriam os "seus sentidos, sua memoria, suas faculdades de associação, de atenção, sua imaginação, seu pensamento abstracto, sua linguagem, seus sentimentos, seu caracter, sua vontade” (p. 12). Complementarmente, tendo em vista os condicionantes psicológicos, aplicar-se-ia uma educação que permitiria à criança "formar em si a vontade, que governa o desejo" (p. 7), e levaria a condutas morais necessárias à sociedade em que vive.

Destarte, Fauconnet ([1929]) insere Durkheim na longa linhagem daqueles autores que, ao inferirem organicidade à natureza humana, imediatamente atribuem à educação um papel fulcral para mantê-los - tanto a espécie quanto os indivíduos nela viventes - em efetiva progressão. Nesse sentido, somente a responsabilidade dos mais velhos para com os mais novos, segundo o próprio Durkheim, garantiria a efetividade do desenvolvimento humano.

Essa responsabilidade seria justificada pela ligação ancestral entre educação e organização social. De acordo com Durkheim ([1929], p. 44), “a sociedade não poderia existir sem que houvesse entre seus membros, uma suficiente homogeneidade: a educação perpetúa esta homogeneidade, fixando de antemão na alma da criança, estas similitudes essenciaes reclamadas pela vida collectiva".

A função socializadora da educação possibilitaria, segundo ele, que o natural egoísmo do infante fosse confrontado com a moralidade própria da vida em comum. Tal confronto permitiria "que o legado de cada geração possa ser conservado e acrescido aos outros" (p. 52), uma vez que "o futuro não se acha estritamente predeterminado por nossa constituição congênita" (p. 60). Portanto, o professor seria o responsável por apresentar a sociedade às crianças, cuja moralidade seria estabelecida pelo constante embate dos instintos individuais com as necessidades coletivas. Daí nasceria, segundo o autor, a autoridade dos mestres. E a efetividade da educação adviria, pois, da capacidade do próprio mestre em incorporar a moral necessária ao bom funcionamento social.

A partir desse entendimento, Durkheim ([1929], p. 66) estabeleceu a máxima: "a liberdade é filha da autoridade bem compreendida". A asserção se justificaria, em sua opinião, na medida em que os educandos - partindo de seu natural egoísmo, portando uma consciência maleável e sendo, assim, incapazes de criar suas próprias representações acerca da vida social 
- entregam-se à condução de seus mestres, que se tornam porta-vozes das tradições e, no mesmo golpe, condutores da sociedade em direção ao futuro.

Os adultos, particularmente os educadores, teriam então o encargo de transmitir às gerações vindouras aquilo que sua sociedade produziu, uma vez que a propagação pela via hereditária somente manteria as mutações nos tecidos corpóreos. Estas não garantiriam novas aptidões para a vida social, o que somente seria realizável pelos sistemas de ensino. Tais sistemas, à luz das ciências da psicologia e da sociologia, poderiam conduzir, respectivamente, as aptidões gerais e a consciência pública em direção a uma sociabilidade adequada ao progresso.

Desse modo, Durkheim ([1929], p. 102) estabeleceu que "o homem que a educação deve realizar, em cada um de nós, não é o homem que a natureza fez, mas o homem que a sociedade quer que elle seja; e ella o quer conforme o reclama sua economia interna". O tema da relação entre a interioridade individual e o meio - ou seja, da produção de uma sociedade cuja economia interna depende das modificações nas condutas dos indivíduos, tanto em sua natureza quanto no ambiente - foi o foco desenvolvido no volume VI da coleção Bibliotheca de Educação.

O autor do livro, Octavio Domingues, atuou fortemente no campo da zootecnia como professor e pesquisador, com grande volume de obras publicadas, tendo sido alcunhado de Patrono da Zootecnia brasileira (FERREIRA, 2006). Também foi membro da Comissão Central de Eugenia da Genetics Association, da Eugenics Society de Londres (DOMINGUES, 1933), um reconhecido cientista que, desde a década de 1920 até a de 1960, participou ativamente do movimento eugênico brasileiro como membro da Sociedade Eugênica de São Paulo, criada em 1918 e operante até a década de 1940.

No último parágrafo de sua obra Hereditariedade em face da educação, Domingues ([1929], p. 158) sintetizou suas ideias dirigindo-se diretamente aos professores e afirmando:

The creature is not mare, but born - deve ser a sua lembrança constante de cada dia, pois que a individualidade da criança é uma coisa hereditária, é um conjunto de virtualidades innatas, que o mestre de hoje deverá saber conduzir e orientar apenas, sem transmuda-las, como aquelles ingenuos alchimistas que buscam fazer ouro ao toque da pedra filosofal.

A primeira frase do parágrafo poderia ser traduzida para a língua portuguesa da seguinte maneira: a criatura não é má, mas é criada. Em outras palavras: seria necessário que todos aqueles dedicados à educação tivessem clareza de que sempre existiu algo prévio à concepção de qualquer ser humano: sua ancestralidade. Aquilo que, para Domingues ([1929]), 
identificaria todos os humanos e, ao mesmo tempo, distinguiria cada uma de suas individualidades seria a sua própria condição de espécie.

Segundo o autor, as virtualidades inatas seriam expressão não de uma condenação, mas da potência absolutamente irrefreável de cada ser humano. A variabilidade, por sua vez, seria um dos mais ricos objetos de estudo a que se deveriam dedicar os especialistas na ciência genética.

Ademais, também no que tange às contribuições dessa ciência à educação, Domingues ([1929]) destacou a variabilidade como elemento fundamental. A genética, ao mapear a complexa diversidade presente na sucessão das gerações, auxiliaria os educadores a estabelecerem um conjunto de características próprias à população em que determinado grupo de alunos se inseriria. Dessa forma, o conhecimento genético ofereceria condições para que o professor antecipasse suas expectativas em função daquilo que naturalmente poderiam oferecer seus pupilos.

Além da variabilidade genética, Domingues ([1929]) apontou para a extrema complexidade dos fatores psicológicos, quando pretendeu aplicar seus conhecimentos sobre a vida orgânica para a compreensão dos processos educativos. Mesmo afastando qualquer dúvida acerca da transmissão hereditária de atributos psicológicos, o autor sobrelevou a importância do ambiente em que tais atributos se formam e se desenvolvem.

Portanto, residiria aí toda a sua expectativa na educação oferecida pelos saberes genéticos: sobre a base cientificamente reconhecível das tendências individuais em dada população, criar-se-ia um modelo educativo dirigido especificamente a ela. Ademais, reconhecidas as potencialidades, poder-se-ia conduzir as qualidades de cada um dos escolares, interferindo no ambiente que os envolve e, no mesmo golpe, ultrapassando a seleção natural por meio de uma seleção social. Ou seja, a escola, orientada pelas especulações provenientes da genética, tornar-se-ia um espaço de sociabilidade protegida e planejada para garantir tanto a seleção dos mais adaptados quanto a expansão de suas tendências individuais.

A fim de estruturar um sistema educacional capaz de reconhecer e expandir tais tendências individuais, diferentes intelectuais ligados à Escola Nova flertaram com os saberes acerca dos biotipos. Apesar de não pertencer à Bibliotheca de Educação, a obra Biotypologia e educação, de Peregrino Junior (1936), oferece elementos consistentes para analisarmos o desdobramento que os conceitos egressos da genética tiveram no ambiente escolar da época.

Peregrino Junior atuou como médico endocrinologista e professor de medicina, literato, tendo sido membro da Academia Brasileira de Letras. Ao longo da vida, assumiu funções públicas ligadas tanto ao jornalismo quanto à medicina. Fundou e presidiu a 
Sociedade Brasileira de Endocrinologia, Biotipologia e Nutrição. Em sua referida obra, publicada pela Diretoria Nacional de Saúde e Assistência Médico-Social, o autor condensou uma sequência de palestras por ele apresentadas a professores primários em 1935.

Em tais apresentações, Peregrino Junior (1936) dedicou-se a demonstrar a evolução dos estudos em torno das relações entre caráter, temperamento, hábito externo e constituição. Definindo cada um desses âmbitos em termos de marcas herdadas e adquiridas na fisiologia humana, o autor dissertou sobre os caminhos pelos quais a ciência da biotipologia poderia auxiliar os professores em sua tarefa educativa.

Ao fazê-lo descreveu o ser humano como o resultado da ação de glândulas, nervos, ritmos, volições, membros em proporção variável conforme as diferentes cargas hereditárias e as diversas influências do meio. Conhecendo tais variações,

[...] o professor conduzirá a sua obra educacional com mais efficiencia, mais firmeza e mais tranquilidade, contribuindo de modo mais conciente e efficaz para a formação harmoniosa do seu espirito e do seu caracter, para a correção dos desvios do seu organismo, para o melhor rendimento das qualidades naturaes (p. 10).

No decorrer de sua obra, Peregrino Junior (1936) mapeou diferentes teorizações acerca das possibilidades de classificação biotipológica dos estudantes. Ao fazê-lo, permitiunos compilar uma cena de antropometria digna de nota: trata-se da relação tronco-membros instituída por Viola. Ela refere-se à

[...] a differença algebrica entre o valor do tronco e o valor dos membros. É a mais importante das relações fundamentaes. É a relação basal, a primeira adoptada por Viola e a única que era tomada em consideração durante muito tempo. Morphologicamente ella analysa as proporções entre o volume do tronco e o desenvolvimento tentacular dos membros. Funccionalmente representa a relação entre o systema da vida vegetativa (tronco) e o systema da vida de relação (membros) (p. 72).

Para que fosse possível estabelecer a relação tronco-membros, dever-se-ia dividir o primeiro em cinco segmentos, antes de medir outras cinco frações dos membros. A primeira medida tronco-vertical daria conta da distância entre a região jugular e o último terço do esterno; a segunda aferiria a distância entre o esterno e a região epigástrica, acima do umbigo; a terceira distaria do epigástrico ao púbis; a quarta mediria o tronco superior, sem considerar as mãos. Com a exclusão do pé, medir-se-ia o tronco inferior-vertical: quinta medida. A horizontalidade seria aferida por meio de outras cinco medidas.

As relações fundamentais referem-se aos números a partir dos quais se desdobrariam todas as outras mesurações passíveis de comparação, quer no volume, quer no comprimento dos corpos investigados. Por meio da dita proporção entre membros e tronco, poder-se-ia 
distinguir os indivíduos longilíneos dos brevilíneos. Nos últimos, predominariam as funções vegetativas, tais como a nutrição e a reprodução; já nos alongados, em virtude da extensão dos membros, prevaleceriam as funções de relação.

A imagem é clara: os longilíneos, por possuírem membros maiores, teriam mais superfície de contato com o mundo, tendendo, portanto, a serem mais habilidosos no que se refere às relações sociais. Tal tendência traria consigo o risco de predominarem os instintos agressivos. No caso dos brevilíneos, o maior volume no tronco predisporia tais indivíduos a maior recolhimento. Ao se ensimesmarem, os brevilíneos ficariam expostos ao risco de desenvolverem comportamentos próprios dos deprimidos.

A partir da relação entre constituição e comportamento, Peregrino Júnior (1936) preocupou-se em dimensionar as reações dos diferentes tipos constitucionais perante certas adversidades, tais como as doenças. Segundo ele, por exemplo: o tipo brevilíneo, quando adoece, "não tendo o ventre, o sexo e os músculos em ordem, elles não comprehendem a vida, porque é disso que depende a sua felicidade e o seu equilíbrio" (p. 50); já os longilíneos reagiriam desacreditando a doença, desprezando-a.

Todas as reações adversas, danosas sob o ponto de vista da salubridade ou da sociabilidade, poderiam ser antecipadas e evitadas, caso tanto os professores quanto os demais condutores das crianças conhecessem a ciência dos tipos morfológicos e se preparassem para evitar ou corrigir o predomínio da tendência natural sobre o bem agir.

Até a leitura dos seis primeiros volumes da coleção Bibliotheca de Educação, não constatamos nenhum traço de determinismo, seja ele social, biológico ou mesmo moral. Os autores trafegaram no interior de uma noção de natureza que em nenhum momento prescinde de uma base biológica, mas também asseveraram como parte dessa natureza um espaço íntimo - psíquico, perceptivo, brincante, ativo, livre, morfológico - em que experimentar mudanças, controlar vontades e desenvolver caráter revelaria o inusitado, o acidental. Inclusive no caso do eugenista Octavio Domingues e do biotipologista Peregrino Júnior, não detectamos nenhuma sedução quanto a possíveis propostas de refinamento da espécie ou regeneração da sociedade, tal como se esperaria após a leitura de Jerry D’Avila (2006) acerca do movimento eugênico.

O trabalho dos psicólogos e pedagogos envolvidos nas teorizações dos primeiros seis volumes concentrava-se na busca pela equação dos acidentes. Por meio da delimitação dos tipos psicológicos, procuravam compreender os diferentes processos pelos quais cada um dos educandos ascendia ao aprendizado. Tomando o aprendizado como um mecanismo que poderia ser visualizado, usavam as próprias respostas dos avaliados para estabelecer 
generalizações acerca do processo cognitivo. Tal como fazem as atuais visual expertises no imageamento humano, os dados que fundamentavam tanto as perguntas quanto as análises das respostas proferidas pelos examinados dos psicólogos experimentais sempre precisavam obedecer a cânones de medição. Esses cânones, mais do que forjarem uma natureza outra, produziam a natureza com a qual os procedimentos escolares precisavam se haver.

Após apresentar, nos seis primeiros volumes, as bases scientificas do ensino, Lourenço Filho derivou a escolha dos textos para aquilo que chamou de meios práticos de educação. Essa divisão não se manteve de modo sistemático, mas poderia explicar a presença da obra Como se ensina a geografia, da autoria de Antonio Proença ([1928]), no sétimo volume da coleção. Na apresentação do volume, o editor advogou por um ensino que se opusesse à antiga geografia, cujo método baseava-se na memorização de "nomes ou da reprodução catographica mecânica" (LOURENÇO FILHO, [1930], p. 5).

Antonio Firmino Proença, sorocabano, atou como professor em diferentes escolas do interior paulista até chegar, em 1927, ao cargo de Inspetor do Ensino Secundário em São Paulo, cidade em que alcançou proeminência quando dirigiu a Escola Caetano de Campos. No volume, Como se ensina a geographia, Proença ([1928]), apesar de preocupado em apresentar os meios práticos de educação, iniciou suas considerações teorizando sobre as relações entre a geografia e a vida e sobrelevando a volubilidade da última. No convívio dinâmico e complexo do homem com o globo, ele localizou nas transformações em ambos o foco para onde que se deveriam dirigir todas as especulações da ciência geográfica.

No entanto, apesar de considerar a geografia uma ciência fundamental para despertar nos alunos o "sentimento de amor à Pátria" (p. 103), o autor priorizou em suas elucubrações a necessidade de o professor preocupar-se com a colocação "em atividade a imaginação, o juízo e o raciocínio" (p. 15). Para tanto, coerente com seu projeto de renovação escolar, Proença ([1928], p. 23) aconselhou um ensino que, ao afastar-se do "exercício de pura memoria", ativasse outros poderes mentais, tais como a "percepção, intuição, memoria, imaginação juízo, raciocínio". Tal projeto não deveria prescindir do aprimoramento do professor com vistas à "boa preparação de linguagem, de historia patria e do desenvolvimento da inteligência do individuo" (p. 25). Antes, o propósito geral proposto por Proença ([1928], p. 25) visaria "satisfazer simultaneamente sob o ponto de vista da cultura geral e o desenvolvimento da inteligência e dos sentimentos do individuo".

Entendendo que "o aprendizado de qualquer sciencia tem de fazer-se com obediencia às leis da evolução mental” (p. 35), o autor orientou ações didáticas que deveriam partir do concreto antes do abstrato, do específico antes do genérico, do próximo antes do distante, “o 
facil antes do dificil, o todo antes das partes” (p. 35). Portanto, ao sustentar suas opções didáticas, optou pela máxima da Escola Nova: a ontogênese irmanada com a filogênese. Ou seja, antes de inocular no aluno sentimentos de patriotismo ou o conhecimento do globo, Proença ([1928]) citou como missão superior do ensino geográfico o exercício do raciocínio do educando a fim de que se desenvolvessem sua inteligência e, por conseguinte, sua humanidade.

Ainda no sentido de voltar a coleção em direção aos meios práticos de educação, Lourenço Filho escalou o professor Coryntho da Fonseca para dissertar sobre A escola activa e os trabalhos manuais. O autor, então diretor da Escola Profissional Masculina Souza Aguiar (MONARCHA, 1997), tal como Antonio Proença, optou por utilizar as digressões didáticas acerca de sua disciplina como pretexto para apresentar suas concepções sobre o aprendizado em geral.

No entendimento de Fonseca ([1929]), os trabalhos manuais não deveriam compor uma disciplina específica, mas ser utilizados por todas as disciplinas, uma vez que a escola renovada proposta por teria de se livrar do passado em que somente se aprendia "pela letra do livro ou pela palavra do professor" (p. 36). Aquela antiga escola, na qual o discente passivo se colocava diante de um professor catedrático cuja única responsabilidade era garantir a qualidade da explanação, deveria se converter em uma escola nova, com alunos ativos e professores agindo como orientadores ou guias, em que o centro de todas as atividades estaria deslocado do ensino para a aprendizagem.

A escola das informações, segundo Fonseca ([1929]), deveria ser substituída pela escola do trabalho, este aí assumido como experimentação cujo princípio se centralizaria nos interesses dos alunos. Assim, uma vez interessado, o infante seria capaz de produzir aquilo que o professor planejara. Tal orientação, de acordo com o autor, deveria levar em conta duas qualidades próprias e superiores dos trabalhos manuais: o resultado imediato e a expressão da capacidade pessoal.

Segundo a sugestão de Fonseca ([1929]), o recurso aos trabalhos manuais, ao permitirem que os alunos observassem o imediato resultado de seus esforços, abriria caminho para uma educação efetivamente moral, uma vez que, no resultado do trabalho, estariam presentes a adesão, a disciplina e a persistência do educando, sem que os educadores precisassem recorrer a pregações de qualquer tipo.

Além de serem comparados consigo mesmos por meio da contemplação do resultado de sua própria lavra, os educandos da escola ativa aí proposta também poderiam, caso seus professores optassem pela didática renovada, comparar suas capacidades às de seus colegas e, 
prontamente, conscientizarem-se de suas limitações e propensões. Consequentemente, poderia a escola "promover todos os meios de livre expansão dos índices bons do organismo psychico em formação, a attenuação, quando não o cancellamento dos maus, sem qualquer preocupação de lhe limitar uma finalidade social ou economica" (p. 142).

Para além da mera transmissão de técnicas artesanais, assim, a disciplina denominada trabalhos manuais, dentro do espírito da Bibliotheca de Educação, converter-se-ia em uma comprovação dos próprios preceitos da escola ativa, procedimentos fundamentados no princípio de que o aluno executa e imediatamente contempla o produto de seu trabalho, corrigindo-o e avaliando-o segundo suas próprias e livres percepções. Uma liberdade, porém, aprisionada tanto às possibilidades oferecidas pela organicidade psíquica quanto às propostas apresentadas pelo professor. Ademais, tal uso da liberdade permitiu a Coryntho da Fonseca ([1929]), tomando por base os indivíduos como seres de atividade, alegorizar o humano como um transformador que converteria eletricidade estática em eletricidade dinâmica.

Ao supor que "o organismo humano transforma a impressão em expressão" (p. 12), o educador teria, segundo o autor, uma tarefa bastante clara: controlar a expressão humana, uma vez que a impressão derivaria da base constitucional de cada qual. Assim, pelo incentivo ao trabalho criativo - a criatividade situada na encruzilhada entre a vontade individual e a capacidade constitucional -, o aluno apreenderia suas próprias verdades, conquistando um aprendizado sem idealizações, no qual o mestre não apenas se ateria aos conteúdos, mas guiaria e orientaria o pupilo.

Forjando-se indivíduos imersos em trabalho criativo, poder-se-ia reverter o quadro que, segundo Coryntho da Fonseca ([1929], p. 19), manteria

[...] o povo victima de todos os effeitos funestos de uma idealização desmandada, por falta de controle da realização. Sem o hábito de realizar, perdemos a noção das responsabilidades de idealizar com bom senso uma subordinação dentro de perspectivas certas, não desmentíveis pelas realidades visadas.

O autor então armou uma didática que partiria do incentivo à criatividade, passaria pelo controle das realizações e chegaria à constituição de um aluno livre e, por conseguinte, um cidadão responsável e pronto para harmonizar suas experiências pessoais com os dados que a realidade apresentasse.

A combinação entre trabalho, liberdade e sociabilidade aparecia, a partir de nossa leitura dos volumes da Bibliotheca de Educação, como uma fórmula a se implantar na modernidade escolar pretendida por Lourenço Filho. Essa impressão é corroborada pela escolha do tema do nono volume da dita coleção. 
Trata-se de A lei biogenética e a escola ativa, publicada em 1929 e assinada por Adolpho Ferrière, pesquisador suíço então ligado à Universidade de Genebra e diretor adjunto do Instituto Jean-Jacques Rousseau. Ferrière foi apresentado como um renomado promotor da Escola Nova e defensor daquilo que na época se denominava escola ativa.

Tal escola, segundo Ferrière ([1929], p. 27), deveria se basear nas "leis em virtude das quaes se realiza todo progresso biologico e psychologico, differenciação e correspondente concentração das suas sãs faculdades ou energias volitivas". Tendo em vista a saúde como pretenso horizonte do desenvolvimento orgânico humano, ao educador bastaria o encargo de estabelecer condições para que a potência do educando se expandisse livremente, uma vez que essa expansão levaria, naturalmente, à conquista das habilidades sociais, intelectuais e produtivas.

Um trabalho pedagógico que se baseasse na liberdade, segundo Ferrière ([1929], p. 14), abrigaria a seguinte máxima: “a melhor mestra da criança é a experiencia pessoal". Em liberdade, o infante teria garantida outra meta da escola renovada: o ensino de dentro para fora.

A retração da centralidade do professor no processo de aprendizagem também foi preocupação para Ferrière ([1929]). Tal como Fonseca ([1929]), o autor suíço considerava que o processo de cognição humana seguia os mesmos passos da investigação científica. Desse modo, os infantes deveriam ser colocados em liberdade para que, em companhia de seus colegas, pudessem observar, criar hipóteses, construir experiências e, por fim, estabelecer leis relativas aos problemas que os professores teriam a tarefa de levantar.

Trabalhando, exercitando-se, experimentando, socializando e movimentando-se, o educando livre poderia, segundo Ferrière ([1929], p. 37), vivenciar em escala reduzida aquilo que fundamentaria a vida humana: "a justa interpenetração da theoria com a pratica". Superarse-ia assim o condenado intelectualismo, próprio das antigas propostas pedagógicas.

Ademais, uma escola fundada no estímulo ao trabalho também cumpriria importante função social, pois "nada vale tanto como a occupação em um trabalho util para despertar na criança, o interesse, a iniciativa, o estusiasmo que são coefficientes indispensaveis de toda educação intelectual e moral" (p. 40). Para o autor, ao desenvolver em seus alunos a "arte de sentir-se seguros de si mesmos" (p. 38), o professor os prepararia para uma sociabilidade harmônica em queas individualidades se manteriam em expansão, conforme suas naturezas.

A escola proposta por Ferrière ([1929]), portanto, despertava, ativava, ocupava e instigava o escolar a indicar ao professor o caminho para seu próprio aprendizado. Tal percurso deveria ser percorrido por dois personagens: aquele que se desenvolveria aprendendo 
e aquele que aprenderia enquanto ensinava. Segundo o autor, os eventuais erros dos educandos deveriam ser tratados, nesse processo, como inadequações das propostas dos mestres diante do estágio de desenvolvimento de seus pupilos.

No entanto, apesar de se afastar do dirigismo, a escola ativa deveria planejar detalhada e cientificamente suas atividades. Para garantir a adequação de seus comandos, o professor teria de estar plenamente consciente das etapas que comporiam o desenvolvimento intelectual dos alunos. Tais etapas acompanhariam as idades e progrediriam do simples ao complexo, ou seja, da fase inicial da infância, em que despertam os interesses imediatos e concretos, até a fase adulta, em que se alcançam as capacidades de abstração.

A constituição do corpo intelectual, psíquico e motor como um organismo capaz de se desenvolver durante a sucessão das idades aparece como um cânone para a visualização de todos os homens, segundo dos partidários da Escola Nova até aqui analisados. Tal cânone foi instituído e lapidado, conforme sobredito, no experimentalismo proporcionado pelos testes. Entre as infinitas testagens relatadas pelos autores selecionados por Lourenço Filho, aquelas que teriam se tornado síntese do escolanovismo e se convertido, por extensão, em importante matriz para a subjetividade moderna seriam as medidas de inteligência. Destas, as que tiveram grande permanência na cultura escolar brasileira foram as elaboradas pela dupla Binet e Simon e abrigadas no décimo volume da coleção Bibliotheca de Educação.

Simon assinou o prefácio desse volume, traçando ali um pequeno histórico das investigações de Binet em torno da correlação entre desenvolvimento físico e mental. Para tanto, ele asseverou que Binet teria partido de seu convívio com crianças ditas retardadas na Colônia de Vaucluse.

O prefaciador descreveu que, em sua compreensão do retardamento, Binet lançara mão de "interrogatórios metódicos" (SIMON, 1929, p. 10) com o fito de distinguir os retardados dos imbecis, idiotas ou débeis. As respostas teriam sido tabuladas e os avaliadores teriam estabelecido uma escala métrica para comparar os diferentes tipos de deficiência mental. Simon relatou que, em 1905, tal trabalho fora publicado sob o título Escala métrica de inteligência.

A partir dessa escala, o Ministério de Instrução Pública de Paris teria então demandado sua aplicação em alunos "que não aproveitassem o ensino na medida de seus colegas". Apontou o autor que se verificava a presença de resultados similares entre os alunos com baixo aproveitamento escolar, seus colegas de menor idade e os retardados. Tal achado estatístico teria entusiasmado Binet e seus assessores a continuarem com as medições. 
Em ambiente laboratorial, reformularam as perguntas do teste anterior e o aplicaram em crianças escolhidas para o experimento. Dessa apuração, chegaram a um inquérito de 60 provas. No entanto, anota Simon (1929), a tabulação das respostas restringia as apreciações dos avaliadores a referências unicamente etárias. Apontou então que "seria preferível utilizar outras etiquetas que essas etiquetas de idade, e falar de inteligências médias, superiores, ou acima de superiores" (p. 21).

Simon (1929) descreveu como essa modificação na nomenclatura permitiria a aplicação do exame em diferentes campos, tais como o criminal e o profissional. Além disso, tal denominação garantiria também o reconhecimento dos "super-normais, destinados a tornarem-se a força viva da nação" (p. 26).

Conforme afirmou o prefaciador, Lewis Terman foi responsável por um projeto que se desdobrou na aplicação da medida de Binet em mais 1000 estudantes de escolas públicas americanas, entre 1910 e 1916 (TERMAN et al., 1917). Após a reunião dos resultados, o psicólogo norte-americano teria instituído o famoso coeficiente de inteligência. Este, para os testadores, deveria ser lido com reverência, uma vez que era por eles considerado o "primeiro exemplo de medida direta do valor psicológico dos indivíduos" (SIMON, 1929, p. 28).

Tal como nas elucubrações de Piéron, que estudava o material humano decompondo-o nos pequenos gestos que constituiriam as competências instituídas pelos elaboradores do exame, Simon (1929, p. 14) também definia a inteligência como "uma resultante, em que intervém memória, juízo, raciocínio etc., em proporções variáveis, conforme o caso". Essa decomposição viabilizava a preparação de provas adaptadas para cada um dos supostos componentes da inteligência; a seguir, realizavam-se questionamentos facilmente aplicáveis a quaisquer estudantes; por fim, poder-se-ia determinar o coeficiente de inteligência de cada um dos avaliados, comparando seus resultados com aqueles aferidos na testagem de seus colegas na mesma faixa etária.

Na comparação dos resultados, novamente se destaca o uso do termo desenvolvimento. No caso das experiências criadas pela referida dupla, tal conceito foi produzido a partir do distanciamento das respostas em relação aos atrazados. Dessa forma, os alunos tidos como incapacitados diante das exigências escolares seriam a referência, e todos os demais avaliados comparar-se-iam entre si a partir da distância com relação aos retardados.

Produzir-se-ia, então, no ambiente dos testes, uma compreensão humana cujas competências em dar nome e sobrenome, mostrar o nariz, repetir números, observar gravuras, repetir frases, dizer o sexo de uma imagem humana, nomear objetos usuais, comparar duas linhas, comparar pesos, copiar e reproduzir figuras geométricas, distinguir manhã e tarde, 
completar figuras e responder a perguntas com progressivos graus de dificuldade seriam consideradas realizáveis por humanos inteligentes. Tratava-se de ações comuns a todos, mas mensuráveis em cada qual segundo sua individualidade.

Destarte, aventamos que a modernidade escolar, instituída por procedimentos como os criados por Binet e Simon, poderia ter surgido da reflexão em torno da seguinte pergunta: o que é a inteligência? A ela, um afamado psicólogo inglês teria respondido: "inteligência é aquilo que o teste mede" (BORING, 1923, p. 35, tradução nossa).

Após a publicação do volume atribuído a Alfred Binet e Theodore Simon, Lourenço Filho, em tom de retrospectiva, divulga uma obra de sua autoria, a supracitada Introdução aos estudos da Escola Nova. Nela, evidencia-se claramente o projeto de aproximar os procedimentos científicos da biologia aos da psicologia. Esse aporte racional da pedagogia viabilizaria, segundo Lourenço Filho, a suprema função da Escola Nova, qual seja, a atuação consciente, autônoma e madura do educando na sociedade em que vive. Preparar cidadãos capazes de conhecer e respeitar as regras de convívio coletivo e, no mesmo golpe, contribuir com suas individualidades para aprimorar tais regras seria o ponto de chegada da educação renovada.

O $12^{\circ}$ volume da Bibliotheca de Educação centra-se na análise da experiência social. Atribuído ao pedagogo norte-americano John Dewey, o livro Vida e educação marcou a substanciosa presença de Anísio Teixeira na referida coleção: o reconhecido educador brasileiro foi responsável pela negociação, pela organização e pela tradução do volume.

Lourenço Filho teria se cativado pelo trabalho pedagógico realizado na Universidade de Columbia, particularmente pelas ideias de Kilpatrick e Dewey. Esse interesse levou o editor a requisitar a Anísio Teixeira a intermediação no sentido de divulgar no Brasil obras desses dois autores (TOLEDO; CARVALHO, 2013). Teixeira, então, recorreu a duas obras de Dewey que, segundo ele, introduziriam o público da coleção nas ideias do autor norteamericano. As obras eleitas foram: A criança e o programa escolar e Interesse e esforço.

No Estudo preliminar que introduz o volume, Teixeira (1930/1952, p. 7) dedicou-se a demonstrar como Dewey entendia a educação como uma espécie de reconstrução da experiência, a qual seria "êsse agir sôbre o outro corpo e sofrer de outro corpo uma reação é, em seus próprios termos, o que chamamos de experiência". O autor brasileiro sobrelevou a preocupação de Dewey em distinguir a experiência humana da experiência dos demais animais. Nessa distinção, apresentou a inteligência como atributo-chave que, ao lado do espírito, "outra coisa não são que hábitos mentais, laboriosa e longamente adquiridos" (p. 9). 
Desse modo, "se a vida não é mais que um tecido de experiências de toda sorte, se não podemos viver sem estar constantemente sofrendo e fazendo experiências, é que a vida é toda ela uma longa aprendizagem" (p. 10). Na esteira de uma contínua troca de experiências, as relações interpessoais se caracterizariam como um processo de busca constante de equilíbrio e adaptação.

O autor estadunidense, segundo Teixeira (1930/1952), buscara comprovar esse espraiamento da ação educativa analisando o gesto dos adultos perante as crianças. Segundo ele, a educação nunca poderia ser oferecida como treinamento, mas apenas como resposta interna do educando a exemplos e estímulos provenientes do mundo externo, desde a tenra infância. Em outras palavras: educar-se-ia através do meio, sempre indiretamente.

Por isso não haveria, segundo Teixeira (1930/1952), nenhum sentido em uma educação que restringisse a liberdade, já que o movimento educativo somente se concretizaria ante uma transformação interna do aprendiz. Tal ocorreria desde que se praticasse o autocontrole sobre a experiência, controle somente atingido quando houvesse equivalente amadurecimento. Portanto, nesse viés discursivo, a educação seria um "atributo permanente da vida humana" (p. 21), uma vida em que os indivíduos, ao atingirem a liberdade plena, afastar-se-iam de toda dependência externa, porque suas impressões pessoais confeccionariam o roteiro de seu próprio desenvolvimento e convívio.

Mergulhando nos dizeres do próprio Dewey (1930/1952), supomos que esse autocontrole da experiência se manifestaria no despertar do interesse. Em tom de síntese, o autor afirmou:

[...] obtém-se interesse, não se pensando e não se buscando conscientemente consegui-lo; mas, ao invés disso, promovendo as condições que o produzem. Se descobrirmos as necessidades e as forças vivas da criança, e se lhe pudermos dar um ambiente constituído de materiais, aparelhos e recursos físicos, sociais e intelectuais - para dirigir a operação adequada daqueles impulsos e forças, não temos que pensar em interesse. Ele surgirá naturalmente. Porque então a mente se encontra com aquilo de que carece para vir a ser o que se deve (p. 85, grifos do autor).

Em natureza, o mundo interno da criança, segundo Dewey, seria um espaço pleno de afetos e simpatias. Nesse sentido, o entorno social apresentar-se-ia a ele como um imenso campo do qual o infante gradualmente se apropriaria. Também o espírito naturalmente livre do infante estaria naturalmente predisposto a interessar-se pelas coisas da vida exterior a ele. Caberia ao professor, portanto, reconhecer as leis psicológicas que, no interior das crianças, regeriam seus instintos e suas tendências para criar um currículo que não se rendesse aos 
antiquados métodos centrados na disciplina, na direção e no controle. A escola proposta por Dewey (1930/1952) apoiar-se-ia na iniciativa, na espontaneidade e no interesse.

Desse modo, observando aquilo que cativava cada um dos alunos, o professor poderia apropriar-se dos atos infantis para "bater o ferro enquanto está rubro" (p. 37) e guindar o interesse infantil para além das capacidades imediatas, provocando saltos em direção ao desenvolvimento do infante. Caso contrário, quando o professor desconsiderasse o sentido psicológico contido nas escolhas de seus conteúdos, ele poderia provocar a "falta de conexão orgânica entre o que a criança já viu, sentiu ou amor e a matéria de estudo" (p. 42). Esse currículo psicologicamente orientado, segundo Dewey (1930/1952), seria um antídoto contra a desmotivação, a desvitalização e a estereotipia próprias daqueles modelos educacionais que desconsideravam a "lei natural da inteligência", qual seja: "achar satisfação em seu próprio exercicio" (p. 44-44).

Ainda se opondo aos métodos tradicionais de ensino, Dewey (1930/1952) encontrou a pedagogia no ponto médio entre o interesse e o esforço. Quanto ao primeiro, o autor disserta que $o$

[...] interesse verdadeiro, em suma, significa, pois, que uma pessoa se identificou consigo mesma, ou que se encontrou a si mesma no curso de uma ação. E daí se identificou com o objeto ou forma de habilidade necessaria à prossecução feliz de sua atividade (p. 64).

Associando diretamente interesse a uma suposta adequação orgânica da atividade externa com as correspondentes funções internas, Dewey (1930/1952) utilizou a ideia de energia para, em princípio, distinguir e, por fim, reunir interesse a esforço. Para o autor, o modo como o professor canaliza as energias dos alunos em direção aos interesses de cada um deles garantiria a efetividade de sua atividade. Quando tais energias fossem dispendidas em atividades descalibradas quanto ao interesse dos educandos, o esforço seria um inútil sofrimento a que o aluno estaria submetido. Porém, caso o esforço coadunasse com os interesses e o professor fosse suficientemente sagaz para elevar a carga de desafios no limite da capacidade dos alunos, realizar-se-ia uma educação eficiente em termos de desenvolvimento dos pupilos; por conseguinte, as energias envolvidas no esforço potencializariam o processo contínuo e infinito da aprendizagem do humano em questão.

No prosseguimento de sua obra, Dewey (1930/1952) criticou uma escola disciplinar e diretiva, contrária a um ambiente de liberdade e iniciativa que despertaria o interesse. Manteve a fórmula de Claparède, segundo a qual dever-se-ia respeitar a criança prestando obediência à sua natureza, e não divergiu de Ferrière quanto ao ensino de dentro para fora. Propondo a direção dos impulsos da criança, ele ofereceu um caminho seguro para levar os 
educandos ao vir a ser que se deve, tal como sugerira a educação moral de Sampaio Doria e Durkheim. Ademais, o autor localizou a escola como espaço propulsor do interesse, cujo despertar natural era imprevisível, pois sustentado na criatividade.

Essa fundamentação de Dewey (1930/1952) engendrou reflexões que se centraram em dois campos: o binômio interesse/esforço e o programa escolar. Quanto ao dito binômio, tal como seus companheiros da Escola Nova, ele imaginava uma educação fundamentada na atividade contra a passividade, no trabalho criativo contra a repetição, no raciocínio contra a memorização, na espontaneidade contra a direção, na motivação contra a cobrança; enfim, Dewey (1930/1952, p. 83) dissertava sobre a vantagem de uma escola moderna perante uma escola tradicional, a qual estaria ainda presa às correntes pedagógicas que se baseavam ora na "concepção puramente interna da mente", ora na "concepção externa da matéria ou do objeto". No intervalo entre os dois movimentos, surgiria uma escola viva, livre, ativa e, antes de tudo, interessante, porque adequada às capacidades dos aprendizes, capacidades estas cientificamente definidas. O programa dessa nova escola não poderia ser um instrumento fechado. Dever-se-ia compor de propostas que se modificariam conforme os interesses dos alunos, ao mesmo tempo em que dirigiria esses interesses para aquilo que os professores, cientificamente cônscios, consideravam o que se deve conhecer.

Em tais escritos, despertou-nos a atenção o fato de que, desde os primórdios da escola reformada dos anos 1920, a observação criteriosa, a anotação persistente e a intervenção segura parecem ter estado sempre presentes no horizonte dos pesquisadores da psique infantil/discente. Assim, máquinas foram produzidas com o fito de apurar as coletas; gráficos, tabelas e quadros definiram as normas; a partir delas, teorizações minuciosas e previsões lógicas foram divulgadas.

Tal momento histórico, condizente com o avanço da concentração urbana no Sudeste do país, foi marcado por iniciativas voltadas a uma pretensa cientificidade definitiva dos processos educativos. Daí os cruzamentos da psicologia experimental com a sociologia, a educação moral, a genética, a estatística, entre outros saberes em voga, todos eles visando garantir uma enunciação tão explicativa quanto preditiva dos diferentes comportamentos.

Parece-nos, ademais, que tais iniciativas operavam no sentido de constituir uma nova figuração da natureza humana. Desse modo, as narrativas de si e, notadamente, as explicações para o sucesso ou fracasso - fossem de caráter escolar, profissional ou social - seriam submetidas a um circuito de definições que codificava as condutas e, ao mesmo tempo, segmentava-as de acordo com um conjunto de atitudes visualizáveis. 
Reafirmamos nossa suposição de que esses modernos cientistas pedagógicos, ao disporem de um montante de códigos em torno dos quais todos os humanos deveriam ser regulados, operaram vivamente em torno da sequência verificação-diagnóstico-prevenção, com vistas a definir as linhas de sustentação de uma educação escolar doravante ativa, livre e moderna.

\section{Tal como os pássaros, cantores do ar}

Adentremos agora o campo dos meios práticos de educação e percorramos os caminhos pelos quais Lourenço Filho imaginava aplicar os recentes conhecimentos acerca da natureza, da saúde e do devir de seus alunos modernos. A partir daqui, não mais seguiremos a sucessão numérica dos volumes da Bibliotheca de Educação, mas as temáticas comuns que eles evocam.

Iniciemos com uma das descrições de práticas compiladas em nossa empiria.

Tempo de aula - De 20 a 25 minutos, três vezes por semana, como exercício sistemático.

$1^{\circ}$ período

$1^{\text {a }}$ FASE - Como recomendámos para os anos anteriores, convem cuidar, nesta fase, da homogeneização da turma, quer em relação à qualidade, quer em relação à velocidade. Para alcançarmos esse resultado, deveremos motivar bem cuidada repetição dos exercícios feitos no ano anterior, criando oportunidade para maior e melhor desenvolvimento dos alunos hábeis.

No $4^{\circ}$ ano, como no $5^{\circ}$, o ritmo só será alcançado por meio do canto, se considerações particulares da classe assim o exigirem. Nesses graus, o ritmo pode ser marcado por simples contagem, por meio de palmas ou por auxilio de um metrônomo, No entanto, se os alunos se interessarem pelo canto, para essa marcação procuraremos dar-lhes oportunidades para trabalho criador. Apresentaremos, assim, situações que os levem a compor novas músicas, novas quadras ou dramatizações, para as classes de $1^{\circ}, 2^{\circ}$ e $3^{\circ}$ anos. Essas composições, que devem ser experimentadas pelos alunos que as tenham composto, conduzirão toda a classe ao traçado dos exercícios fundamentais e de suas combinações, treino sempre necessário e indispensável à aquisição de maior domínio de movimentos, constância de inclinação e leveza (MARQUES, [1936], p. 121).

O exercício descrito por Orminda Marques ([1936]), que à época era diretora da Escola Primária do Instituto de Educação do Distrito Federal e assistente de Prática de Ensino da Escola de Educação do mesmo Instituto, poderia se referir a uma aula de esportes. A alusão à velocidade e à qualidade dos movimentos bem poderia ser dirigida à corrida, a algum tipo de arremesso ou a movimentos de dança em alguma atividade coletiva que demandasse uma gesticulação homogênea da classe. Poder-se-ia imaginar também que se tratasse de 
exercícios matemáticos, uma vez que a diretora menciona a necessidade de repetição e habilidade, atributos que, concomitantemente à velocidade e à qualidade, seriam demandados tanto pelos esportes quanto pela matemática. Especular-se-ia ainda que a aula em pauta seria de música, pela óbvia referência ao canto e ao ritmo, os quais, como a velocidade, a qualidade, a habilidade, a homogeneidade e a repetição, também seriam ações requisitadas pelo aprendizado da música. Ou talvez o exercício fosse uma atividade de desenho, em que todas as condutas enumeradas se combinariam com a criatividade para possibilitar o ensino da arte ou mesmo de rudimentos de arquitetura.

Tratava-se, porém, de uma aula de escrita, mais exatamente daquilo que contemporaneamente chamaríamos de aula de caligrafia.

É interessante observar que, independentemente do resultado final, o processo educativo apresentado por Orminda Marques ([1936]) mostrou sua preocupação em mobilizar diversos aspectos da gestualidade do educando em direção à execução do exercício. Uma primeira especulação permitir-nos-ia aventar que o domínio da escrita, em si, não é prioritário em relação à sequência de atividades propostas à classe. Essa suposição nos revelaria uma aula que priorizaria a disciplina. No entanto, considerando a maneira como a professora se utiliza do canto, poderíamos ventilar algo para além do disciplinamento.

Notemos que o canto, inicialmente, marcaria apenas o ritmo do exercício e deveria ser logo substituído pelas palmas ou pelo metrônomo. Ao se aperceber da possibilidade de emergir a criatividade, porém, a educadora sugeriu a manutenção da canção, desde que reelaborada e posteriormente socializada com colegas de outros anos escolares. O ensino da escrita, nesse momento, seria conduzido por meio de uma espécie de orientação da vontade, diante da qual se demandaria a adesão coletiva, porque criativa, a uma atividade inicialmente dirigida ao treino de ações individuais. Todavia, onde se esperaria uma condução disciplinar apoiada apenas em comandos do professor, encontrar-se-iam incitamentos à livre manifestação individual.

Poderíamos especular que, apoiado no interesse, o estímulo à criatividade dos aprendizes garantiria a adesão voluntária dos alunos às aulas. Como desdobramento dessa atividade, em uma posterior teorização sobre a vida infantil, poder-se-ia construir um mapa científico da alma dos infantes, cujas linhas seriam produzidas pelas próprias crianças no processo natural de sua inventividade. 
As observações acerca da aprendizagem da escrita muito contribuiriam para tal teorização, uma vez que, segundo Marques ([1936], p. 28), "ligada embora às atividades do pensamento e da sensibilidade, a escrita é um jogo de movimentos, de ações musculares". Essa mobilização de ações psicológicas e fisiológicas ofereceriam aos pesquisadores modernos condições para monitorar a velocidade, a qualidade, a vontade, a coordenação e a boa atitude diante da escrita, objetivando a visualização de um ritmo natural cuja referência se estabeleceria na comparação daquilo que naturalmente se esperava de um e do que efetivamente realizavam todos os alunos observados, conforme suas idades.

Isabel Orminda Marques, em 1932, assumiu a direção da Escola Primária do Instituto de Educação do Distrito Federal, onde se dedicou à realização do estudo que deu origem ao $26^{\circ}$ volume da coleção. Tal estudo percorreu os anos de 1933 a 1936 e foi dirigido à sondagem sobre os fundamentos psicofisiológicos envolvidos no ensino da escrita.

Nesse trabalho, a autora dissertou sobre movimentos naturais e comportamentos individuais diante da escrita. Em relação à natureza do gesto escrevente, apontou tanto a ancestral prática humana dos grafismos quanto a predisposição muscular a esse tipo de gesto. No que tange à interioridade psicológica, dissertou acerca das mais recentes pesquisas sobre a maturidade, às quais os estudos de Lourenço Filho (1933/[1937]) serviam de guia. Quanto à apreciação das atividades musculares, Marques ([1936]) recorreu a trabalhos de fisiologistas preocupados em quantificar os movimentos dos olhos, das mãos, dos braços e a resistência do corpo todo à fadiga, entre outros aspectos; no caso da maturidade, voltou-se aos dados dos numerosos levantamentos oferecidos pelas experiências realizadas na escola sob sua direção. Entre observações e tabulações, os pedagogos recrutados por Lourenço Filho formulavam seus olhares. Ainda na seara do ensino da escrita, Firmino Costa ([1932]), autor do $17^{\circ}$ volume, focalizou as conexões entre pensamento e linguagem, tendo em vista as suposições psicofísicas envolvidas no ato de escrever. Segundo ele:

As cousas trarão as palavras, e as palavras trarão as cousas. Palavras e expressões serão seres vivos, que darão vida ao pensamento. Os alumnos se apropriarão da linguagem como meio de vida social e profissional, como auxiliar do dever e do trabalho. Será ella a saude do espirito a garantir a saude do corpo, refletindo para esse fim sobre as consequencias dos atos (p. 15).

O então diretor da escola normal de Belo Horizonte, o professor Costa ([1932]) mostrou-se preocupado em estabelecer um programa de ensino que contemplasse essa dupla função da escrita: de vivificação do pensamento e de integração do indivíduo ao modo social. A escrita, na condição de expressão, concomitantemente, da personalidade e da sociabilidade, 
realizaria, segundo o autor, uma ponte entre os desejos naturais e os efeitos das condutas consolidadas pelo escrevente em aprendizado. Voltar-se a si mesmo, referenciando a própria atitude na reação dos outros a seu comportamento, seria o desejo que os professores deveriam insuflar em seus alunos, garantindo a conexão do pensamento com a linguagem por via da auto-reflexividade.

Expressão da efetividade do ensino, a conquista da escrita emanciparia o educando, fazendo-o "andar sozinho nos dominios da intelligencia" (p. 16). Portanto, em liberdade, o estudante percorreria o programa definido por Costa ([1932]) em direção a si mesmo. Tal programa previa exercícios organizados segundo as idades, considerando os interesses infantis emergentes em cada etapa de desenvolvimento.

Assim como Orminda Marques, Costa ([1932], p. 13) aconselhava que os professores se libertassem de qualquer artificialismo para conseguir "proceder qual o commerciante, que não impõe a mercadoria ao freguez, antes satisfaz a este, procurando vender-lhe o que deseja”. Libertar o professor do artificialismo, na lógica discursiva defendida por Lourenço Filho e presente na Bibliotheca de Educação, significava demandar dele um conhecimento profundo, não somente de sua própria matéria, mas também dos processos psicobiológicos envolvidos na aprendizagem. Ainda mais: significava armá-lo com virtudes intelectuais suficientes para torná-lo um educador tolerante, equitativo e justo em sua inteligência (LOURENÇO FILHO, [1931a]).

Com esse espírito, foi encomendada a tradução de Cruz Costa para a obra Situação actual dos problemas philosophicos, do agregé de filosofia Andre Cresson ([1931]). Nesse $13^{\circ}$ volume, ficou evidente a função da Bibliotheca de Educação como manual de formação para professores.

Ao longo de toda a obra, Cresson ([1931]) dedicou-se a definir as diferentes linhas em que se assentou a história da filosofia no Ocidente. Nesse trajeto, afastou-se tanto das correntes metafísicas quanto das excessivamente racionalistas, para em seguida afirmar sua tese segundo a qual "a escolha de uma philosophia deve se fazer por um impulso de vontade e por considerações de utilidade vital" (p. 65, grifos do autor).

No desdobramento do livro, é perceptível a defesa de uma filosofia sem grandes teorizações. Todas as especulações de Cresson ([1931]) relativizavam a verdade e, no mesmo golpe, aventavam o caráter formativo do exercício do pensamento. Sua filosofia deveria levar os alunos a meditarem sobre " $1{ }^{\circ}$ Quaes os fins a que nos devemos propor na vida? $2^{\circ}$ Que meios empregar para realizar estes fins" (p. 81).

Em tom de síntese, o autor questionou e, em seguida, respondeu: 
[...] quaes são os seres que têm com effeito, estados de conciencia? Quaes são os typos de espiritos que existem no mundo conhecido por nós? Como podemos classificá-los? A que leis obedece a sua actividade? Como as idéas, os sentimentos, as vontades se formam? Como reagem umas sobre as outras? Como procurar explicar as estructuras dos differentes espíritos? Quais as phases do desenvolvimento do espirito e como interpretá-las? São todas questões analogas ás questões biologicas; todas, questões que nada obriga a considerar como insoluveis (p. 84).

Para Cresson ([1931]), não existe possibilidade de encontrar nenhuma verdade absoluta quando se investiga a vontade e os propósitos inerentes à vida humana. No entanto, as certezas presentes na natureza biológica da vida serviriam, segundo o autor, de referências para toda reflexão acerca da vida misteriosa do espírito humano.

No $16^{\mathrm{o}}$ volume da referida coleção, Estevão Pinto ([1931]) também se propôs a analisar alguns aspectos desse espírito humano. Para tanto, tomou como referência a constituição da sociedade brasileira. Enfocando suas análises naquilo que denominou formação da mentalidade popular no Brasil, o autor - professor da Escola Normal de Pernambuco - construiu um panorama histórico da sociedade brasileira e ressaltou o viés elitista nela presente.

Desse modo, pretendendo estabelecer as bases para generalizar um convívio democrático no país, Pinto ([1931]) findou por recorrer à educação a fim de concretizar a tarefa. Evidentemente, seriam os princípios da Escola Nova que conformariam os maltrapilhos, no sentido de prepará-los para obter aquilo que nunca tiveram: liberdade. Fato notável é que essa liberdade, nunca efetivada por nenhum dos sucessivos formatos de Estado brasileiros somente poderia ser vivenciada, segundo o autor, caso cada um dos cidadãos dela desfrutasse no interior de si mesmo, ainda na condição de estudante.

Condição indispensável para a instalação da democracia, a liberdade somente adviria quando, desde criança, os brasileiros experimentassem a vida coletiva própria dos exercícios escolares dirigidos à formação profissional, às ações extraescolares e às atividades colaborativas, sempre no sentido de despertar "a solidariedade social; e, afinal, o regime da autonomia, ou self-government, que revela as individualidades e crea a liberdade interior" (p. 101). Destarte, a Escola Nova, ao irradiar mecanismos de autogoverno, criaria cidadãos equilibrados quanto ao jogo entre as vontades individuais e as atividades coletivas. Deveria ser considerada, portanto, uma instituição de fundamental importância para a redenção dos populares no Brasil e, por extensão, para a democratização de toda a sociedade.

No sentido de ampliar progressivamente o alcance social da escola, Jonathas Serrano e Francisco Venancio Filho ([1931]) - ambos professores do Colégio D. Pedro II - dissertaram 
sobre cinema e educação no $14^{\circ}$ volume da coleção. Ao fazê-lo, saudaram as iniciativas vanguardistas de Mussolini no sentido de mobilizar os países europeus associados à Liga das Nações para expandirem um amplo projeto de cinema educativo por todo o velho continente.

As potencialidades educativas e massificadoras do cinema foram aplaudidas pelos autores com entusiasmo. Ademais, a contemplação do realismo e o consequente estímulo à sensibilidade emocional dos alunos seriam, segundo eles, as grandes contribuições do cinema educativo, uma vez que, além de popularizar os conhecimentos escolares, também levariam o mundo para dentro da escola.

Em meio a considerações sobre o uso das imagens em movimento no ministério de algumas disciplinas e o desaconselhamento desse uso em outras, os autores desenvolveram aquilo que consideravam o sumo objetivo do cinema educacional: o caráter multiplicador da educação que ele oferece. Tal caráter foi encontrado nas pesquisas científicas acerca do impacto psicofisiológico do recurso cinematográfico, o que foi estabelecido pela dupla de autores por meio da descrição de uma experiência realizada pelo Instituto Superior de Bruxelas. Na ocasião, reuniram-se dezenas de crianças em uma sala de projeção e apresentouse a elas algumas horas de imagens cinematográficas. Assuntos como ciência, viagens, agricultura, higiene e comédia se desenrolavam em "kilometros de fitas" (SERRANO; VENANCIO FILHO, [1931], p. 92), enquanto os infantes estavam atrelados a instrumentos que mediam suas funções vitais.

\begin{abstract}
[...] após uma sessão de duas horas, com dez pausas de 1 minuto, verificouse que a força physica, no dynamómetro diminuia de um quinto. A sensibilidade cutanea, que acompanha a curva da fadiga cerebral medida no esthesimetro, mostrou que esta, ao cabo das duas horas é dupla entre alguns indivíduos do que o era após duas horas de aulas. Os tremores, registrados no tremometro, augmentam consideravelmente nos cardiacos e nervosos. Os reflexos pela percursão de certas articulações exacerbaram-se. Os nevropatas, têm o corpo percorrido por espasmos; os congestivos, cephaléas; os de visão diminuida, apresentam-na mais diminuida ainda (p. 92).
\end{abstract}

Muito além dos recursos didáticos que o cinema apresentaria, os autores mostraram-se atentos às implicações propriamente fisiológicas da atividade. Fadiga mental, movimentos involuntários e atuação da visão foram os efeitos investigados. Interessou à dupla a comparação desses efeitos com os provocados pelas aulas; por fim, dedicaram-se a mapear as respostas orgânicas conforme os diferentes temperamentos.

A modernidade oferecida pelo recurso ao cinema deveria ser, de acordo com Serrano e Venancio Filho ([1931]), aproveitada em termos dos estímulos que ele exercia. O despertar do interesse via excitação orgânica era o atrativo da ação cinematográfica sobre as 
individualidades. Restaria, finalmente, controlar, por via da regulamentação estatal, os assuntos a serem tratados pelos cineastas no sentido de operar "uma impregnação na alma de milhares de adultos e crianças, que veriam, por todos os recantos do Brasil passarem e repassarem estas fitas-lições, instructoras e educadoras de um povo" (p. 112).

$\mathrm{O}$ aspecto da popularização dos ensinamentos oferecidos pela escola também foi assunto do volume XXV da Bibliotheca de Educação. Também assinado por Jonathas Serrano ([1935]), o texto debruçou-se sobre o sentido e as potencialidades do ensino de história. Tal como na teorização acerca do cinema escolar, o autor voltou-se para a função social da transmissão dos conteúdos especificamente abordados pela disciplina, mas concentrou seus comentários nos efeitos psicológicos dessa transmissão, fosse da atuação do professor, fosse dos perigos e potencialidades na apropriação da referida disciplina pelos alunos.

Em tom de síntese ao final da obra, Serrano ([1935], p. 134) apontou "a noção de extrema complexidade dos fatores psychologicos, individuaes e sociaes, a da acção do meio sobre o homem e da solidariedade humana através do tempo e do espaço - são tantas lições importantíssimas que nos ministra o estudo da história”. A história fora tomada como pretexto para motivar um desenvolvimento individual sadio e, no mesmo golpe, para garantir uma atuação social positiva e colaborativa - essas seriam as metas profundas do ensino proposto por Jonathas Serrano ([1935]).

Determinado a inserir os fundamentos da Escola Nova no sistema educacional brasileiro e, tal como vimos até aqui, sofisticar a vida psicobiossocial do país, Lourenço Filho destinou alguns volumes da Bibliotheca de Educação para apresentar alguns modelos educacionais coerentes com essa moderna sofisticação.

Abner de Moura, diretor do grupo escolar de Angatuba, foi escalado para discorrer sobre o sistema Decroly. Este, segundo o prefaciador, poderia ser considerado uma alternativa à antiga escola livresca cuja palavra era monopolizada pelo professor-narrador. Tal sistema, inclusive, possibilitaria ao docente abdicar do domínio absoluto sobre os conteúdos a serem abordados (LOURENÇO FILHO, [1931b]).

Ao apresentar os estudos de Decroly, Abner de Moura ([1931]) deu relevo ao compromisso do médico belga com uma educação científica. Nesse particular, afirmou, preocupava-se Decroly com o ensino dos retardados. Na tentativa de educá-los, o europeu, conforme a narrativa de Moura ([1931], p. 8), encontrou referências a partir das quais estabeleceria todo o seu princípio educativo, qual seja: "da mesma forma que a actividade industrial aproveita residuos de materia prima industrializaveis por processos novos", uma 
educação renovada poderia também dinamizar as aptidões dos atrasados cognitivos e ensinálos, potencializando suas capacidades.

Cônscio da onipotência do ato educativo, o professor cientificamente orientado encontraria no sistema Decroly, segundo Moura ([1931]), a convocação ao exercício criativo de seu magistério. O objetivo desse método seria encontrar "e manter constantemente a communicação espiritual com os discipulos" (p. 15). Para tanto, o docente precisaria adentrar a história pessoal de cada um de seus pupilos com o firme propósito de encontrar os interesses que orientariam a execução do programa educativo.

Ao emergir desse conhecimento idiossincrático, o professor precisaria desenvolver toda a sua criatividade para encontrar assuntos suficientemente gerais no sentido de atrair a atenção global da classe. Assim, caso os interesses pessoais coadunassem com os interesses dos colegas, cada qual dos educandos praticaria com prazer as atividades propostas pelo docente.

A base de tais atividades seria constituída pelas ações de observação, associação e expressão. Nesses três momentos, aproveitando "o gosto natural das crianças de narrar e descrever", o professor teria condições de, progressivamente, desenvolver as atividades mentais suficientes para que seus alunos questionassem os porquês e os comos dos diferentes assuntos e, enfim, dessem "corpo ao pensamento" (p. 33).

Para Moura ([1931]), portanto, a educação nova adviria no momento em que os professores abdicassem de programas inflexíveis, horários determinados e espaços fechados. O método Decroly seria, então, o método da plena liberdade, uma libertação dos antigos compêndios, da antiga rotina, do antigo confino; uma liberdade somente conquistada após o conhecimento profundo das aptidões e potencialidades mentais dos escolares.

Nessa abordagem dos problemas práticos de ensino, destacam-se outros três volumes assinados por autores que também se dedicaram a pensar a escola livre, democrática e científica em termos da instituição de sistemas de ensino por ela inspirados. Foram eles: $A$ escola única, de Lorenzo Luzuriaga ([1934]); Educação para uma civilização em mudança, de William Kilpatrick ([1933]); e Tendencias da educação brasileira, de Lourenço Filho ([1941]).

Luzuriaga foi um pedagogo espanhol com larga atuação no movimento socialista. Participou da organização educacional do Estado espanhol nos anos que antecederam a Guerra Civil Espanhola. Após a instalação do franquismo, exilou-se na Argentina, onde manteve sua atividade de professor e pedagogo. Sua defesa da Escola Nova remonta à criação 
da Revista de Pedagogia, em 1922, e à tradução e publicação das obras de John Dewey, além de intensa atividade política pela escola unificada.

O volume Escola única foi lançado em 1931 e, no Brasil, foi traduzido por Damasco Penna para ser publicado na Bibliotheca de Educação em 1934. Na obra, Luzuriaga ([1934]) estabeleceu aquilo que ele próprio propôs como a unificação completa do ensino nacional: uma "escola para todos, para os capazes e para os incapazes" (p. 12), de todas as classes sociais, das diferentes vertentes religiosas, ou seja, um sistema escolar que levasse a uma comunhão absoluta "em uma unidade espiritual superior, a alma nacional” (p. 16).

Existentes desde Platão, quando este se preocupou com a formação dos cidadãos para a política, passando por Comenius e seus princípios da escola comum, Pestalozzi e a generalização da escola primária, Condorcet e sua escola universal, entre outros, os princípios da Escola única, segundo Luzuriaga ([1934]), deveriam basear-se no conhecimento psicológico de cada estudante, garantindo um ensino adequado às capacidades individuais.

As individualidades deveriam ser atendidas no interior de um ambiente de plena valorização da diversidade. Um sistema que abrigasse multiplicidades nacionais, culturais e sociais obrigaria os professores a prepararem-se para as diversas circunstâncias escolares que poderiam encontrar. Nesse sentido, Luzuriaga ([1934]) defendeu uma formação docente completa, com obrigatoriedade para o nível universitário. Tal formação deveria incluir o apego ao igualitarismo, ao universalismo e, antes de tudo, "a unificação ou estruturação orgânica do ensino, de acôrdo com os principios da justiça social, das aptidões psicológicas e da conveniência social" (p. 100). Ou seja, tratava-se da redenção da humanidade pela utopia socialista, utilizando como ferramenta a ciência das aptidões psicológicas.

Uma escola adequada às mudanças sociais foi também preocupação de William Heard Kilpatrick. Companheiro de Dewey, militou com ele nos seus mais produtivos momentos da escola de professores da Universidade de Columbia.

No volume XVIII da Bibliotheca de Educação, Kilpatrick ([1933]) realizou um longo diagnóstico acerca da então configuração social que o mundo vivia. Abordando o grande desenvolvimento técnico que os países industrializados teriam alcançado e as consequentes mudanças atinentes à nova atitude mental que essas transformações provocariam, o autor apontou a democracia como único sistema político suficientemente confiável para que tais mudanças não redundassem em desagregação.

No que tange a essa nova atitude mental, necessária à manutenção da democracia, Kilpatrick ([1933]) localizou na escola o lugar privilegiado para que tal sistema se efetivasse. Para tanto, as instituições escolares deveriam assumir a tarefa de voltarem-se diuturnamente 
ao exercício do pensamento experimental. Este, segundo ele, evocaria atitudes em que "cada qual deve desenvolver-se, exprimir-se, de tal forma que, da propria expressão, resulte simultâneamente o desenvolvimento e a expressão de todos juntos” (p. 27). Ou seja, quando a escola criasse condições para que seus alunos pudessem viver no interior dela as permanentes novidades presentes no restante da sociedade, os aprendizes seriam capazes de produzir por si mesmos soluções para sua própria inserção no mundo volúvel que se lhe apresentava.

Assim, segundo o autor, decairiam as condições do tradicional autoritarismo e ascenderia a possibilidade de os professores assumirem uma autoridade positiva. Esta seria dirigida ao desenvolvimento do autocontrole em seus alunos, possibilitando que, pela via da inteligência e não do medo, os pupilos internalizassem as ações suficientes para o convívio democrático. Na pedagogia proposta por Kilpatrick ([1933], p, 77), portanto, o autocontrole seria o ponto de chegada da ação de educadores cônscios de sua tarefa de promover e assegurar o pleno desenvolvimento "de uma mentalidade social” em seus pupilos.

Ainda no campo da análise sobre os sistemas educacionais sob o prisma da Escola Nova, Lourenço Filho publicou em 1941 o $29^{\circ}$ volume da Bibliotheca de Educação, dedicado a sopesar as Tendencias da educação brasileira. A empreitada constou da reunião de quatro textos, apresentados sucessivamente a convite do Departamento de Imprensa e Propaganda, da Liga de Defesa Nacional, do Comando da Escola do Estado Maior e do Instituto Brasileiro de Geografia e Estatística. Conforme as ideias ali desdobradas, o momento histórico situado, as entidades interessadas e os locais de apresentação escolhidos, percebe-se claramente um modo específico de o escolanovista relacionar-se com o tema da democracia, também tratado por autores com ascendência no movimento, como Kilpatrick, Dewey e Luzuriaga.

Enquanto Kilpatrick sobrelevava a intensidade das mudanças sociais e, em consonância a elas, a necessidade de o ensino desenvolver a autonomia dos estudantes, Lourenço Filho ([1941]) deslocou o tema da liberdade individual para o tema de uma “educação 'brasileira', de objetivos e conteúdo nacionais” (p. 28, grifo no original). Assim, o autor brasileiro usou o termo tendência no sentido propriamente estatístico e, por isso, orientou seu olhar para a progressão numérica de determinados dados acerca da supostamente constante e ascendente participação das massas no ambiente educacional nacional.

Nas tendências destacadas por Lourenço Filho ([1941], p. 49), a temática do aprendizado voltado às potencialidades individuais, comumente presente ao longo de toda a Bibliotheca de Educação, foi substituída por uma formulação segundo a qual o ensino deveria ser "um empreendimento sentido e desejado pelo povo, como obra necessária à direção e desenvolvimento da vida social". Nesse sentido, a sociedade, que na quase totalidade dos 
textos da coleção era apresentada como expressão das diferentes individualidades, agora passaria a ser tratada como um empreendimento do cidadão enquanto componente do povo. $\mathrm{O}$ indivíduo, convertido em elemento estatístico, era então reposicionado para a condição de construtor de uma nova ordem nacional.

Além disso, a escola, que anteriormente deveria se orientar no sentido do conhecimento e do desenvolvimento dos interesses de seus educandos, "deixou de ser, por isso, simples instrumento de transmissão de cultura, para chamar a si decisivamente, na qualidade de órgão público - órgão do Estado - função mais larga de coordenação e regularização das necessidades de vida coletiva" (p. 57).

A escola unificada de que falava Luzuriaga ([1934]) consistia em uma escola para todos, garantindo um ambiente fundamental para a constituição de uma alma nacional no interior da qual as diversidades deveriam ser respeitadas e potencializadas. Já nas palavras de Lourenço Filho ([1941], p. 58), essa mesma escola deveria se tornar um espaço de regularização, em que a gratuidade seria substituída pela obrigatoriedade a fim de que as instituições oficiais cumprissem seu papel de suscitar nos escolares "sentimentos de maior coesão social, no sentido de aumentar a disciplina interna e de garantir a continuidade histórica de cada povo, em face de outros povos".

Aquilo que Lourenço Filho ([1941]) chamava de coesão social ficou melhor esclarecido por seu texto Educação e segurança nacional, proferido em 1939 na Escola do Estado Maior do Exército. Na ocasião, o autor retomou o tema da escola como reconstrução da experiência - tal como asseverara Dewey - para reafirmar o papel do ensino no sentido "da garantia da existência individual aquí e além, e, por ela, à segurança das formas sociais de que seja expressão" (p. 100).

Ainda recorrendo a Dewey, Lourenço Filho ([1941]) discorreu sobre a relação do Estado com a educação. Asseverou, nesse aspecto, que ao Estado caberia a tarefa de assegurar o pleno progresso da nação por ele representada. Para tanto, o povo deveria estar preparado para as mudanças que tal desenvolvimento geraria; tal preparação ficaria a cargo da escola. Esta adquiriria uma função ainda mais consistente na vida social do povo, qual seja: a manutenção da segurança nacional. Demandava-se, assim, aquilo a que a Escola Nova sempre se propôs: "uma educação intencional, conciente e planejada" (p. 107).

Tal planejamento, conforme a conferência intitulada Estatística e educação e apresentada em 1938 no Instituto Histórico e Geográfico Brasileiro, seria garantido por meio de um uso sistemático e proposital da estatística. Afirmando que "não será exagerado dizer-se que a estatística tenha criado assim, por sua vez, o Estado moderno" (p. 129), Lourenço Filho 
([1941]) apontou os procedimentos estatísticos como o princípio fundamental para a afirmação da veracidade de quaisquer práticas científicas. Segundo ele, um Estado somente poderia racionalizar suas ações preventivas e, ao mesmo tempo, progressistas a partir da ciência contábil.

No caso da educação, asseverou o autor que, quando ela adquirisse vultos massivos, necessariamente demandaria um planejamento pela via da quantificação. Tal planejamento serviria tanto ao direcionamento dos movimentos realizados pela coletividade nacional, quanto à análise do desempenho de cada indivíduo diante da média do grupo a que ele pertencesse. Dessa maneira, por meio da estatística, poder-se-ia realizar diagnósticos e prognósticos cujos graus de acerto seriam previstos pela ciência das probabilidades. Assim, escorada numericamente, qualquer ação, fosse em direção à população de escolares fosse em direção a um único indivíduo, sempre se situaria no interior de uma gradação que partiria do erro absoluto à certeza absoluta. Ou seja, a relatividade própria dos fenômenos naturais e dos fenômenos psicológicos seria dominada pela metodologia científica.

A consagração da estatística como garantia de planejamento dos movimentos coletivos e, concomitantemente, como racionalização do desempenho individual exerceu, no $20^{\circ}$ da Bibliotheca de Educação, papel fulcral na emergência de uma prática com longa duração na história dos métodos de alfabetização no Brasil (MAGNANI, 1997).

Na obra Testes ABC para verificação da maturidade necessária á aprendizagem da leitura e escripta, Lourenço Filho (1933/[1937]) relatou um empreendimento por ele encabeçado no sentido de produzir, aplicar e teorizar acerca de um conjunto de provas com o fito de apreciar o momento correto para a alfabetização nas escolas públicas de São Paulo. A testagem foi aplicada em 1931 em São Paulo, em 1932 em Belo Horizonte, em 1933 no Distrito Federal. A primeira delas foi a grande aplicação: 15.605 crianças. No total, ao longo dos primeiros três anos de testes, o autor contabilizou 40.116 casos na implementação da primeira edição de seus testes.

Com base no resultado dessas sondagens, na atuação dos professores perante a elas, no comportamento das escolas e no desempenho dos alunos, Lourenço Filho (1933/[1937]) estabeleceu os parâmetros para suas medidas em larga escala. Acompanhando "o pensamento de que tudo o que existe existe em certa quantidade e, assim pode ser avaliado, comparado ou medido" (p. 7), ele buscou teorizar as intenções e os efeitos de seus procedimentos para garantir a segurança na realização de um amplo e massivo processo de alfabetização.

Para tanto, dedicou-se a estabelecer a distinção entre três referências a partir das quais se convencionava, à sua época, indicar o início do letramento. Aventavam os então 
especialistas - fundamentalmente os seguidores do experimentalismo de Binet e Piéron - que a idade cronológica e a idade mental deveriam ser os critérios basais para o início do ensino da leitura e da escrita. Contudo, complementar e suplementarmente a eles, Lourenço Filho (1933/[1937]) sugeriu o princípio da maturidade. Tal medida aferiria a aptidão para o início do ensino formal da leitura e da escrita. Uma criança pronta para o letramento seria aquela que apresentasse uma "maturação biofisiológica" (MAGNANI, 1997) suficiente para tal atividade.

Considerando a leitura e a escrita como atividades mecânicas, Lourenço Filho (1933/[1937]) argumentou que aferir tal maturação seria conhecer as reações próprias de qualquer fisiologia normal diante do estímulo para tais atividades. Embora aceitasse a variabilidade das reações individuais perante as excitações, o autor mantinha a crença de que tais variações seguiam um padrão natural, conforme a idade.

Sustentava tal crença na observação do mundo animal. Conforme suas palavras, "a experiencia mostra que, em virtude dessa maturação crescente e condicionamento basico, é que o animal ou a criança vem a passar do estadio de reacção global, não discriminada, para estadios de conductas crescentemente discriminadas" (p. 38). Dessa forma, enquanto não conseguissem diferenciar os gestos considerados necessários para ler e escrever, os infantes ainda não estariam preparados para receber o treinamento para tal atividade.

Fixando no corpo fisiológico a referência estável para iniciar o ensino da leitura e da escrita, pôde Lourenço Filho (1933/[1937]) aprimorar um conjunto de provas que aferisse as condições biopsicológicas de seres em prontidão para vivenciar a rotina dessa aprendizagem. Tal aprimoramento fora decantado após anos de experiências realizadas, desde 1925, quando Lourenço Filho ainda era docente na Escola Normal de Piracicaba. Em seus ensaios, chegou a um teste com 22 provas para o exame da referida maturidade. Na tentativa de simplificar o teste - para que ele pudesse ser usado em escolas sem muitos recursos, assim como por professores com pouco treinamento e até por pais de alunos -, estabeleceu um conjunto de oito provas cuja aplicação mediria "coordenação visivo-motora, memória imediata, memória motora, memória auditiva, memória lógica, propalação, coordenação motora, mínimo de atenção e fatigabilidade" (p. 157).

Tais provas deveriam, segundo o autor, ser aplicadas simulando para o avaliado a atuação em um jogo. Qualidade na cópia de figuras, tempo de lembrança de figuras observadas, reprodução de figuras desenhadas no ar pelo examinador, entre outros aspectos, compunham os cânones a partir dos quais os psicólogos e professores definiriam não somente 
a propensão à leitura e escrita, mas fundamentalmente o grau em que o examinado se encontrava diante dos colegas de sua idade.

Embora orientados especificamente para o desenvolvimento da escrita, os Testes ABC foram apresentados como subsídio para um projeto de ampla reforma no ensino. A mudança adviria em razão de três aspectos: a seleção de turmas, o controle sobre o trabalho do professor e o par diagnóstico/prognóstico das dificuldades escolares. Quanto ao primeiro, Lourenço Filho (1933/[1937]) defendeu as virtudes do ensino em classes homogêneas. O sucesso dessa prática aferir-se-ia no aumento da velocidade de aprendizado daqueles alunos que, tendo potencialidades fisiológicas comuns, progrediam de modo uniforme diante das propostas dos professores.

Além disso, conscientes das possibilidades e dos limites de seus alunos, poderiam os professores preparar atividades coerentes com os desempenhos aferidos nos testes. Ao mesmo tempo, os chefes dos serviços educacionais teriam controle sobre a produtividade dos docentes atuantes em classes da mesma faixa etária.

Por fim, a testagem estabelecida por Lourenço Filho (1933/[1937]), após discriminar os mais preparados e garantir a adequação do trabalho pedagógico a grupos de fisiologias assemelhadas, poderia oferecer a todos os envolvidos no processo educacional dados objetivos acerca dos déficits funcionais daqueles que não conseguiam acompanhá-lo com a esperada velocidade. Poderia, a um só tempo, interferir para a minimização do déficit, organizando um prognóstico coerente com as suposições fisiológicas estabelecidas tanto pelos produtores quanto pelos aplicadores dos testes.

Tal olhar objetivo para a fisiologia, em nossa leitura, esteve presente na totalidade dos volumes da Bibliotheca de Educação. Essa visualização poderia ser considerada por nós mera "moda de época" (MAGNANI, 1997, p. 72). Se assim o fosse, retomaríamos dita coleção simplesmente como a expressão de um passado, suas imagens revelando representações de tempos que não voltam mais, mas que ainda hoje sustentam significações e sentidos. Condenaríamos todas as atuais hipóteses de pesquisa dirigidas à Escola Nova simplesmente à função de elucidação e à condição de gabarito de compreensão das razões subjacentes à política, à cultura, à sociedade ou a quaisquer outras estruturas. Estas seriam, enfim, doadoras dos sentidos recobertos pela superficialidade dos discursos.

No entanto, não estamos interessados nem em estudar representações nem em vasculhar permanências, pois entendemos que ambos os enfoques guardam, em algum aspecto de suas argumentações, gestos interpretativos em que termos como infância, aprendizado, desenvolvimento, família, sociedade, interesse e experiência são utilizados na condição de 
conceitos. Esse tipo de enfoque parece-nos estar presente em boa parte dos atuais enunciados acadêmicos dirigidos à Escola Nova. Em alguma instância, cremos, tal perspectiva preserva uma abordagem transcendente na qual aspectos biológicos, psíquicos ou sociais são tidos como universais àqueles que pretendem compreender a vivência escolar moderna. Esse enquadre, asseveramos, mantém o estudioso aprisionado em apenas duas funções: revelador dos preconceitos biopsicossociais ou narrador de um estranho passado que atormentaria o presente e embelezaria o futuro.

Ao investigarmos os textos compilados por Lourenço Filho na Bibliotheca de Educação, não tivemos a pretensão de espreitar incongruências ou intencionalidades; antes, dirigimos nossa atenção para a ascensão e a queda de determinadas ligações teórico-temáticas que raramente estiveram ausentes das práticas educacionais desde que surgiram. Não se tratou de mirar a permanência de objetos, mas a manutenção de vínculos. A análise de tal manutenção nos leva a aventar ligações ocasionais, contingenciais e arbitrárias que teriam configurado a pedagogia de base psi como um campo discursivo tão específico quanto genérico: específico em seus objetos, mas genérico para explicar uma suposta natureza humana.

Das ligações presentes na Bibliotheca de Educação, destaca-se o modo como os enunciados compilados atrelam desenvolvimento e natureza. Escorada em uma longínqua identificação da criança com o selvagem - tributária de uma peculiar apreensão do darwinismo -, tal ligação contemplaria uma essência própria a todos os viventes. Sua inexorabilidade e sua progressividade apontariam sempre para o futuro, fosse no caso dos retardados sugeridos por Binet (1929), dos atrazados afetivos supostos por Arthur Ramos (1939) ou dos próprios selvagens referidos por Lourenço Filho ([1930]).

$\mathrm{Na}$ compreensão dessas anormalidades, fossem elas relativas a objetos psicofísicos, higienistas ou reformistas, impreterivelmente estiveram em cena fatores ligados ao tempo e às estruturas biológicas. Tais fatores demonstrariam, em uma ordem reconhecível e previsível, a adequação das cobranças, a compensação dos atrasos e o saneamento das diferenças, tanto no corpo populacional quanto no corpo individual dos educandos.

De acordo com as análises de Canguilhem (2005) acerca da manutenção do hipocratismo em diferentes campos da ciência moderna, se a natureza fosse concebida como remédio para os males, todos aqueles que nisso cressem imediatamente se entregariam às explicações de quem codificava em palavras o funcionamento dessa natureza. Tendo em vista que, desde pelo menos o século XVII ocidental, o conhecimento científico acerca da vida natural foi considerado "nunca acabado e sempre aberto para novas eventualidades" 
(FOUCAULT, 1999a, p. 76), quem comungasse com esse modo de pensar, ao narrar os acontecimentos de sua vida, inevitavelmente deveria incorporar o vocabulário instituído pelos especialistas no estudo da natureza para conceituar sua própria individualidade, canonizando uma visualização de si como ser em permanente processo de aperfeiçoamento e cura. Desse modo, a definição da educação em termos de condição natural de humanização, tal como aludiu Durkheim, acabaria por entronizar a infância como ponto nevrálgico de aplicação desses especialistas na natureza humana.

Tal percurso, na medida em que operasse com a sequência diagnóstico/elucidação/ prevenção, instituiria, acreditamos, um campo de visualização para coroamento de uma determinada concepção de natureza, tal como Clifford Whittingham Beers alegou abrigar em seu próprio crânio.

Senão, vejamos: na psicopedagogia moderna, assim como na anatomia novecentista, os cientistas da vida operaram uma corporeidade fragmentada. A decomposição das ditas bases fisiológicas em elementos visualizáveis por testes, recortes e medições segue as possibilidades tanto técnicas quanto matemáticas disponíveis. Tecnicamente, só se pode testar e medir aquilo que é quantificável, seja o movimento dos olhos, a velocidade das respostas, o tempo das lembranças ou o grau de fadiga; matematicamente, só se pode aferir aquilo que é comparável. Estabelecida a quantificação técnica e pronunciada a tabulação matemática, segue-se a definição do status biológico. Nesse itinerário, o estabelecimento de graus de normalidade permitiria estabelecer o tipo biológico que configuraria o indivíduo; definido o biotipo, disparar-se-iam as suposições genéticas por meio das quais se poderia vincular cada ente isolado à sua população correspondente.

Até esse ponto poder-se-ia afirmar que estaríamos no interior do domínio normativo da psicologia experimental. No entanto, a composição dessa ciência com as práticas escolares teria feito surgir uma paisagem na qual - ao lado dos dados objetivamente calculáveis vocábulos como atividade, trabalho, brinquedo, jogo, autocontrole, liberdade e criatividade passariam a compor o rol de condutas que demandavam a atenção dos cientistas do aprendizado. Teriam assim emergido problematizações como caráter, tendências e processos mentais, com o intuito de classificar ditas condutas e estabelecer critérios objetivos para definir seres moralizáveis, previsíveis e programáveis.

Entretanto, a definição de tais comportamentos, tal como se evidencia na exposição dos 5.764.801 de tipos de caráteres ventilados por Geenen ([1929]), apresenta um grau de intangibilidade que parece contrastar com a pretensa objetividade dos estudos que levaram a esses números. Intuímos então que, mais do que definir exatamente a norma em que se 
encontrariam os humanos submetidos às experimentações biológicas que os definem, essas experimentações ofereceriam critérios a partir dos quais cada um identificaria sua própria vida e a visualizaria como uma vida inusitada, porém determinável no interior de uma tipologia científica.

Destarte, recorremos ao mesmo raciocínio para compreender a busca incessante que os psicopedagogos modernos empreenderam para demarcar os processos mentais do aprendizado. Também esses processos se mostravam intangíveis, mas auscultá-los permitiu aos especialistas constituir vocábulos que se anexaram à natureza dos avaliados, possibilitando-lhes sua própria conformação nas infinitas possibilidades de mensuração.

De todos os processos mentais, a criatividade e a ludicidade são os que melhor evidenciam esse movimento. Tais elementos foram, no jargão escolanovista aqui tratado, imediatamente associados às considerações sobre a infância, e esta, por conseguinte, apresentada como o grau zero do humano. O infante demonstraria, por meio de sua vitalidade e de sua inventividade, o estado ativo dos processos mentais que possuiriam impulsos em germe para o seu aprendizado.

Desse modo, a educação escolanovista tornou a criança o centro de seus cuidados, apontando para uma responsabilização do aprendiz pelo seu próprio desenvolvimento. Assim, criar-se-ia um humano autônomo, pois consciente de suas capacidades e livre para adentrar a moralidade instituída pelo seu entorno social.

Fato parecido ocorreria, supomos, com a hereditariedade. Ela foi empregada pelos intelectuais da educação moderna como uma maneira de estabelecer as bases fisiológicas do aprendizado. Sua inacessibilidade, parece-nos, teria sido resolvida pelo estabelecimento da noção de tendências. Estas se revelariam como o fundamento a partir do qual todo humano seria composto e, ao mesmo tempo, cada um dos indivíduos se diferenciaria. A objetividade genética somente seria possível por meio do inquérito das anormalidades. E a sondagem daquilo que inviabilizava a adequação de um ente à sua população seria o guia por meio do qual os geneticistas insinuariam suas potencialidades e os educadores guiariam suas condutas.

Dessa maneira, reconhecemos um percurso que se inicia na descrição de comportamentos, circula por métodos interventivos e desagua em visualizações sobre a natureza humana. Em todos os pontos desse caminho, tendo em vista a especificidade das reações, foram estabelecidos modelos científicos para estabelecer generalizações e garantir o manejo das individualidades.

O conjunto formado por escolares, como vimos, seria também um agrupamento de corpos com características específicas: infantes em desenvolvimento, seres potencialmente 
livres, personalidades em modelagem, cidadãos em preparação, cérebros em aprimoramento, enfim, corpos desenvolvendo-se enquanto forjados pelos discursos que os definiam.

Fato evidente: toda essa corporeidade foi constituída nos laboratórios de psicologia experimental, no interior dos quais a antropometria ofereceria as referências anatômicas para que os experts instigassem os avaliados à livre autoprodução de corpos educáveis, corrigíveis, criativos e ativos; em síntese: aprimoráveis. Tratava-se, portanto, de uma educação voltada ao autodesenvolvimento, um procedimento que partia do indivíduo e propalava sua redenção social pela conquista de sua própria autonomia.

Ademais, a aventada ligação entre desenvolvimento e natureza seria, segundo propomos, uma das mais intrincadas criações estabelecidas pela expertise médico-psicológica. Esta, quando disposta aos infantes/educandos pela Escola Nova, teria generalizado para vastos campos de convívio a auto-responsabilização pela vida, facultando a cada qual a possibilidade de ser o médico da própria alma em um corpo capaz de aprimoramento. 


\section{Personagens e enredo: a roupagem acadêmico-pedagógica}

Um olhar, mesmo superficial, para os discursos escolanovistas encontraria evidentes cânones higienistas. Muitas das invocações estabelecidas pela medicina oficial em meados do século XIX parecem ter encontrado campo fértil no cotidiano escolar moderno. As razões para tal simbiose inspiraram diferentes gerações de estudiosos.

Enveredemos agora pelos escritos daqueles que se propuseram a problematizar os efeitos produzidos no encontro da Escola Nova com os corpos e as almas dos alunos por ela abrigados. Tais discursos não nos permitiram compreender nada acerca de uma suposta realidade. Eles tampouco nos esclareceram sobre o escolanovismo. Simplesmente nos apresentaram problematizações que parte da tradição historiográfico-pedagógica brasileira tornou visíveis e, nesse trajeto, consolidou vieses explicativos contra os quais dirigiremos nossa crítica.

A historiografia da educação brasileira possui vasto material acerca das relações que, desde o século XIX, o discurso médico estabeleceu com a vida sociocultural, na qual se incluiu a escola moderna. Mapeemos algumas linhas dessa produção discursiva.

No que tange à formulação de uma narrativa sobre a especificidade da composição biológica dos brasileiros, a pesquisa de Lilia Schwarcz (1993) foi-nos fundamental. Ao vasculhar escritos médicos brasileiros publicados em periódicos e teses ao longo do século XIX pelos homens de ciência, Schwarcz (1993) ateve-se à maneira como tais personagens dirigiram-se às questões raciais com o fito de mapear a formação de uma civilização propriamente brasileira.

A respeito disso, a autora descreveu a ascensão e a queda de diferentes teorias, adaptações filosóficas e posicionamentos políticos, os quais pareciam desembocar no fato de que o "pensamento racial europeu adotado no Brasil não parece fruto da sorte. Introduzido de forma crítica e seletiva, transforma-se em instrumento conservador e mesmo autoritário na definição de uma identidade nacional" (SCHWARCZ, 1993, p. 42). Nesse sentido, ser brasileiro significaria inserir-se em modelos estrangeiros que, nos casos aventados pela autora, articulariam a nacionalidade à longa história de formação e de perpetuação da hereditariedade humana.

No interior das diferentes práticas discursivas apresentadas por ela, nota-se a manutenção da centralidade da relação homem/meio na constituição da hereditariedade biológica. Essa lógica argumentativa, tributária do darwinismo, fixaria, segundo Schwarcz (1993), desde meados do século XIX até as primeiras décadas do século XX, o ambiente 
como objeto de preocupação dos profissionais ligados tanto à promoção da saúde quanto à garantia do desenvolvimento nacional.

Adotando abordagem parecida, Jerry D'Avila (2006) estudou os enunciados biológicos nos tempos do escolanovismo em termos de um grande programa liderado por uma "elite branca médica, científico-social e intelectual emergente" (p. 22). Tal programa, com roupagem eugênica, envolveria, segundo o autor, associações de cientistas, ligas e institutos que "funcionavam como um lobby na defesa de um papel maior do Estado no tratamento das causas da degeneração" (p. 54) racial.

Influentes intelectuais como Lourenço Filho, Anísio Teixeira e Arthur Ramos foram descritos por D'Avila (2006) como agentes de um grande e interligado plano para aplicar, no complexo quadro racial brasileiro, as novidades científicas estabelecidas pelo eugenismo europeu. Em dito contexto, teriam sido implementados testes psicológicos, verificações educacionais, pesquisas sociológicas, medidas de biotipos, serviços de cinema, panfletos publicitários, inventários, departamentos, relatórios de higiene, revistas pedagógicas - enfim, um abrangente e articulado conjunto de ações cujo objetivo comum seria purificar ou regenerar a raça brasileira. Por meio desse propósito, segundo o autor, "as pesquisas quantificavam indutivamente impressões sobre raça e classe em vez de observações registradas sobre condições sociais reveladas nas escolas" (p. 92).

Todas essas iniciativas eugênicas teriam regredido após a Segunda Guerra Mundial, mas mantido o perfil planificador, tanto nas políticas governamentais quanto na visão de mundo de burocratas e intelectuais. Dita herança, de acordo com D’Avila (2006), fixou a estatística como método de racionalização, planejamento e centralização das políticas educacionais. A estatística teria sido, então, o solo comum no qual se assentariam os testes psicológicos, antropométricos ou de desempenho - que viabilizaram, ao longo do século XX, teorizações normalizadoras segundo as quais "ser pobre ou não-branco explicava deficiências no desenvolvimento" (p. 229).

Também Heloisa Helena Pimenta Rocha (2003) dedicou-se a problematizar práticas próprias do higienismo brasileiro a partir das relações entre ambiente e desenvolvimento. A autora, analisando a ação da Fundação Rockefeller na criação, em 1918, do Instituto de Hygiene de São Paulo, apresentou a maneira como médicos, fisiólogos, nutricionistas, microbiólogos e estatísticos, entre outros especialistas, teriam se apoiado em padrões estrangeiros para realizar modificações nos moldes higiênicos praticados pelo conjunto dos habitantes da capital paulista. Os profissionais sanitaristas, conforme a autora, seriam aqueles 
que "se auto-representavam como porta-vozes" (p. 15) de um novo civilismo que deveria elevar o brasileiro aos padrões próprios dos países avançados.

A influência adventícia foi tratada por Rocha (2003) como um conjunto de normas orientadas para persuadir a população paulista da necessidade das medidas sanitárias. $\mathrm{O}$ viés persuasivo e não coercitivo dessa normalização pela via do sanitarismo justificou, para a pesquisadora, a inserção dos enunciados higiênicos no interior das escolas.

Desejada tanto por pessoas da elite quanto pelas classes populares, a higiene teria sido aplicada fundamentalmente nos bairros pobres, o que levou Heloisa Rocha (2003) a sublinhar o caráter elitista dessas intervenções. O caminho de tal elitização teria incorporado um complexo sistema de representações que lançava mão de fotografias, disciplinas escolares, traçados urbanos e práticas de vigilância, sempre no sentido de alastrar para a sociedade os projetos estrangeiros que cumpririam a função mais ampla de confinar as classes dominadas em sua condição de subalternas a um poder sobredeterminante e burguês; poder este que operava por meio da responsabilização de cada qual por sua própria saúde. Tratava-se, então, da "formação de uma consciência sanitária" (p. 168), na qual a educação teria tido papel central.

O sistema educacional, nessa perspectiva, teria colocado suas práticas "a serviço da obra de modelagem" (p. 181) da vida dos escolares. Para tanto, forjar-se-ia - partindo da plasticidade do sistema nervoso infantil - uma educação fundada em uma noção de natureza cujo modus operandi seria determinado e modificado pelos detentores do saber higienista. Tecer-se-ia, assim, um sistema de hábitos higiênicos coerente com os princípios civilizadores e morais caros à elite que os forjara. Nas palavras de Rocha (2003, p. 228, grifo da autora), a partir da escola, "os homens de ciência procuraram configurar a cidade em um espaço educador, conformador de novos gestos e de novas práticas do corpo", viabilizando o espraiamento de um amplo repertório de intervenções conjuminadas para inculcar nos dominados as ações desejadas e propaladas pelos dominantes e por seus parceiros norteamericanos.

Maria Helena Souza Patto (1984) também considerou o sanitarismo como um grande programa dedicado a manter as classes subalternas em sua condição de inferioridade. Segundo a autora, a história da psicologia escolar poderia ser escrita como uma longa e persistente estratégia de segregação e subalternização das classes dominadas. Assumindo como papel do intelectual "o conhecimento ou a revelação das estruturas obscurecidas pelo discurso ideológico" (PATTO, 1984, p. 86), sua própria tarefa política é definida como a responsabilidade por "apreender o sistema de representações sobre a sociedade, a escola e a 
psicologia" (p. 160) a fim de nele intervir, desalienando seus atores da irreflexão, uma vez que "o conhecimento tem início pela resistência ao senso comum e aos estereótipos" (p. 183).

A tese de que o racismo, o preconceito e a subalternização seriam ações para encobrir, de maneira persistente e violenta, uma estratégia voltada a manter os privilégios de classe foi defendida por Patto (1984) de modo aguerrido. Conforme ponderou ela, o intelectual teria a responsabilidade de imiscuir-se no cotidiano das classes dominadas e dar publicidade à sua voz, despertando suas consciências para a verdadeira raiz de seus males sociais e psicológicos, qual seja: a desigualdade de classes. Desse modo, a autora estabeleceu a sociedade como um espaço em que conflitariam representações do real, cabendo ao acadêmico traduzir para os populares aquele conjunto de imagens que obliterariam tomadas de posição verdadeiras - porque rigorosamente científicas - sobre si mesmos e que, por extensão, acabaria por levá-los à revolução social.

Margareth Rago (1985), assim como Maria Helena Patto, analisou as relações entre dominantes e dominados no início do século XX sob o prisma da criação de uma "representação imaginária construída pela sociedade burguesa" (p. 17). Em sua obra Do cabaré ao lar, a autora tomou como objeto de análise textos produzidos pela imprensa operária, notadamente de viés anarquista, na São Paulo recém-industrializada do início dos anos 1910, e os confrontou com documentos oficiais ora de caráter estatal ora de tonalidade médico-sanitarista, com o fito de sopesar as imposições e as resistências diante das ações de modelagem que, segundo ela, funcionavam como "tentativa de domesticação do operariado" (RAGO, 1985, p. 12).

Apontando suas preocupações para o que denominou disciplinamento da classe operária, Rago (1985, p. 20) voltou-se para os três espaços que configurariam "a imagem edulcorada do mundo do trabalho projetada pelo imaginário burguês" e passou a discorrer sobre os personagens que conviveriam em cada um desses espaços. Seriam eles: a fábrica, o lar e a escola. A fábrica seria o lugar de atuação dos homens adultos; o lar, das mulheres; e a escola, no idílio burguês, o abrigo das crianças.

Tendo como referência o jogo entre dominação e resistência, a autora descreveu o confronto entre diferentes projeções imaginárias. De acordo com ela, a imagem da fábrica higiênica seria projetada como um ambiente de obediência, ordem hierárquica e controle; o lar deveria guardar, nas projeções burguesas, o recato feminino, sua moralidade e sua fertilidade; já as crianças deveriam estar em escolas ou em casas de assistência, protegidas tanto dos perigos das ruas quanto da exploração dos industriais inescrupulosos que insistiam em submetê-las ao trabalho fabril. Todos esses projetos de ordem social sintetizar-se-iam na 
criação de vilas operárias, no interior das quais a normatização sonhada pelos burgueses seria compartilhada pelos operários que se sujeitassem ao modelo higiênico-disciplinar.

A resistência operária ao modelo burguês, conforme asseverou Rago (1985), contraatacava com a seguinte tríade: fábrica satânica, mulher livre e criança racionalmente educada. Daí a demonização da fábrica levar os operários a constituírem-na como um ambiente de exploração, de violência e de aprisionamento. No caso da imagem anarquista da mulher livre, a autora encontrou o aborto, a abdicação da amamentação e a anulação do matrimônio como alguns dos exemplos da obstinação feminina. Quanto ao encaminhamento das crianças, ela deparou com as propostas da pedagogia anarquista que contemplavam um ideário segundo o qual "a criança possui aptidões naturais positivas que as práticas pedagógicas devem ajudar a desenvolver" (p. 149).

Considerando que os autores supracitados trafegam por caminhos argumentativos semelhantes, cujos trajetos incluem associações como racismo/ideologia estrangeira, Estado/normalização dos subalternos, consciência sanitária/modelo burguês, senso comum/alienação e representações burguesas/contenção da liberdade operária, entendemos que nenhuma dessas ligações escapa da constatação de que haveria uma sobredeterminação de certos grupos sociais sobre os subalternos. Tal opção por uma suposta configuração assimétrica do poder sugere que os subordinados são meros reagentes diante da sanha discriminatória dos higienistas. A seleção das fontes, a justificativa para as cronologias e o enfoque sobre as relações parecem-nos sempre se afunilarem em direção à mesma conclusão: a operação de um grande plano de manipulações e ocultações que somente se prestariam a manter os dominantes em suas posições de privilégio.

Em nossa compreensão das referidas abordagens, a intelectualidade, os médicos, os burocratas, os industriais e os pedagogos tiveram seus enunciados lidos como se sempre dissimulassem algo que parecia ser o âmago de todas as nuances de argumentação. Ou seja, ao defenderem a imposição de uma identidade nacional, estariam escondendo a supremacia da raça branca; ao propalarem a salubridade pública, estariam ocultando as alianças com o imperialismo elitista; ao estigmatizarem como deficientes as crianças pobres, estariam mantendo-as na subalternidade; ao normatizarem a vida dos operários, estariam domesticando-os em direção ao modo de vida burguês; ao indicarem a seleção das matrizes genéticas da população brasileira, estariam entronizando o branco como raça preponderante.

Julgamos que nessas análises pode-se vislumbrar a manutenção de determinados métodos tradicionais de pesquisa, entre eles: a crença na assimetria do poder, a confiança no esclarecimento como vetor de redenção social e a fé na progressão técnico-científica. Em 
nosso entendimento, tais procedimentos, tributários de alguma leitura do marxismo, mantêm modelos estruturalistas, teleológicos e racionalistas de análise, $\mathrm{Ou}$ seja, ditas pesquisas conservariam exatamente os mesmos fundamentos dos saberes e poderes que pretendem criticar. Assim procedendo, encontrariam elas pouco espaço para compreender a produtividade própria a toda relação saber-poder. Produtividade em termos de cânones de visualização, ou seja, em termos de produção de teorias, práticas, consensos que entronizaram concepções com potenciais condutivos muito mais profundos, uma vez que não se utilizaram apenas da imposição ou da manipulação, cujo exorcismo poderia ser realizado diante da conscientização política.

Tais cânones de visualização são tidos, na presente investigação, como marcas dos processos de subjetivação que teriam aderido aos corpos modernos como se implantadas na própria carne. Desse modo, cremos poder refletir concretamente sobre as condições de emergência dos processos biocientíficos atuais voltados ao aprimoramento individual, uma vez que, assim o supomos, para que tais processos se efetivassem, não bastaria uma ação assimétrica ou impositiva; antes, necessitar-se-ia da vontade ativa do indivíduo.

Ao entrarmos em contato com a historiografia há pouco sintetizada, assim como com a discursividade escolanovista presente na Bibliotheca de Educação, supomos que o século subsequente à década de 1850 viu surgir consensos a partir dos quais raramente os homens ocidentais puderam abster-se; dentre eles, destacamos a aceitação da existência de um corpo genético, orgânico e modificável. Visivelmente, tal evidência emergiu no mesmo momento da instalação de discursos racistas, sanitaristas e modeladores. No entanto, em nossas conjecturas, não bastaria ultrapassar os excessos das teorias e manter a crença nos cânones que elas geraram. A crítica precisa ir além.

Assim, a fim de analisar o estado atual da crítica acadêmico-pedagógica em relação à visualização corpórea instituída pelo momento higienista, tomamos artigos acadêmicos publicados na passagem do século XX para o século XXI acerca do tema. Tal escolha deveuse basicamente a três fatores. Primeiramente, no âmbito metodológico, consideramos que esses textos possuem estatuto semelhante ao escrito que ora realizamos: tanto aqueles quanto este foram confeccionados em ambiente universitário, seguem padrões científicos de argumentação e dedicam-se a desenvolver análises originais no interior de determinadas linhas teóricas. Portanto, ambas as produções textuais bem poderiam ser tidas como produtoras de cânones científicos para visualização da presente subjetivação pedagógica.

Outro fator relaciona-se ao corte temporal escolhido para iniciar a compilação dos artigos. Nesse caso, foram iniciadas as apreciações em datas próximas e posteriores à 
instituição dos Parâmetros Curriculares Nacionais (BRASIL, 1997), marco temporal eleito em razão do espírito reformista que, tanto hoje quanto ontem, gerou expectativas similares no que tange à emergência dos cânones escolanovistas para a visualização de práticas escolares.

Por fim, a opção pelos artigos compilados deveu-se à posição deles diante dos critérios estabelecidos pela Coordenação de Aperfeiçoamento de Pessoal de Nível Superior (CAPES). Tendo tais critérios em vista, escolhemos 18 periódicos ${ }^{8}$ avaliados nas categorias Qualis A1 e A2 como alvo de nossa sondagem, o que atestaria a circulação e a atribuída qualidade das publicações, bem como garantiria que os artigos selecionados apresentassem hipóteses chanceladas, praticadas e reconhecidas pelos meios acadêmicos.

Fizemos, destarte, uma sondagem em artigos científicos cujo tema central abrigava a Escola Nova, o que congrega a análise de práticas sanitárias, terapêuticas e higiênicas cuja visualização do corpo teria se estendido para a subjetividade contemporânea. Ademais, a fim de garantir, ao mesmo tempo, a abrangência e a precisão da empreitada, recorremos à sondagem por meio de palavras-chave, focalizando termos cuja recorrência foi suficiente para mapear deslocamentos e congruências teórico-temáticas em torno das relações que o discurso educacional contemporâneo brasileiro estabeleceu com os cânones de visualização corporal instituídos pela prática escolanovista. Ao longo da pesquisa, os descritores foram então se avizinhando a termos como: Escola Nova, higiene, medicina, saúde, clínica e psicologia.

No desenrolar das leituras, constatamos apreciações que se nos apresentaram como grandes blocos de teorização. Optamos, assim, por registrar o percurso de 56 textos que receberam destaque devido à explicitação da opção teórica empregada. Relacionando os artigos segundo seus temas, suas referências, suas fontes, seus objetos, suas proposições e suas opções teóricas, observamos o deslindar de concepções bastante evidentes no que tange à visualização escolanovista dos corpos de escolares.

A partir dessas concepções, procuramos orientar a pesquisa com base em uma abordagem específica. Esta tomaria os enunciados dedicados a problematizar a Escola Nova como unidades produtoras de conexões conceituais, as quais teriam operado por meio da apropriação do escolanovismo como matriz de perspectivas teóricas acerca da educação no presente. Ou seja, ao mesmo tempo em que observávamos a constituição das críticas,

\footnotetext{
${ }^{8}$ Trata-se de publicações próprias do campo pedagógico, editadas entre 1993 e 2013. São elas: Cadernos CEDES, Cadernos de Pesquisa, Currículo sem Fronteiras, Educação em Questão, Educação em Revista, Educação e Pesquisa, Educação Temática Digital, Educar em Revista, Educação \& Realidade, Educação \& Sociedade, Perspectiva, Práxis Educativa, Pro-Posições, Revista Brasileira de Educação, Revista Brasileira de Estudos Pedagógicos, Revista Brasileira de História da Educação, Revista de Educação Pública e Revista Educação.
} 
vislumbrávamos, nos elementos dessa mesma crítica, conexões conceituais com larga permanência na história dos processos de subjetivação na escola.

Destarte, após a leitura detida dos artigos, apercebemo-nos de algumas repetições, ora na abordagem das fontes, ora na escolha do objeto, ora na opção temática, ora em sua fundamentação filosófica. Tais repetições permitiram-nos constituir um encadeamento textual, possibilitando a aproximação de grupos de artigos em que as regularidades poderiam configurar perspectivas para nossa própria análise.

Tomamos os citados escritos acadêmicos, pois, como uma série discursiva na qual a temática da Escola Nova se apresentou como uma máquina por meio da qual se proliferaram enunciados acerca de objetos caros ao presente. Tal fonte não nos deveria esclarecer nada acerca do escolanovismo, tampouco nos permitiria formular uma história completa ou mais erudita acerca daquele movimento. Em vez disso, sua utilidade seria apenas a de possibilitar a escrita de uma história da educação brasileira preocupada em deslindar processos de subjetivação até hoje em plena operação. Para tanto, voltamo-nos às conexões temáticas que foram atribuídas à pedagogia escolanovista e que se mantiveram dignas de problematização para o atual pensamento pedagógico, estabelecendo enfoques específicos para os corpos e as almas dos educandos.

Em 2009, Antonio Marques do Vale publicou um artigo dedicado à Abordagem de um tema complexo de história: a relação entre finalidades da educação, poder e interesses. No texto, o autor evocou uma teorização que se fundamentava nas acepções de Gramsci, trafegava pelo crítico-reprodutivismo de Althusser e chegava às concepções de Bourdieu e Passeron, no assumido intuito de entender o papel desempenhado pela Escola Nova em termos de relações de poder. Sua análise voltava-se tanto aos Estados Unidos da América dos tempos de John Dewey, quanto ao Brasil da década de 1930.

Em linhas gerais, Vale (2009, p. 42) incluiu a Escola Nova em "um movimento que sempre se assimilou aos interesses de modernização e industrialização”, cuja empresa a consolidaria “como 'reserva ideológica' sempre disponível e em favor da hegemonia burguesa". A insinuação de aparelho ideológico concedida à Escola Nova permitiu ao autor formar fileiras com aqueles pensadores dedicados "à denúncia do liberalismo e das ilusões da Escola Nova" (p. 44). O suposto liberalismo escolanovista teria se combinado ao positivismo 
e ao pragmatismo para realizar uma operação considerada, pelo autor, fundamental para a afirmação do capitalismo, qual seja: agir sobre os alunos de modo a torná-los consumidores.

A “marca pragmático-positivista” teria operado no sentido de "quebrar as resistências dos operários e levá-los ao espírito de cooperação", relançando permanentemente "o projeto burguês como uma boa notícia e evangelho" (p. 44-45). Tal projeto se formularia pelos próprios pais dos proletários quando aceitassem que a educação garantiria uma vida melhor para seus filhos. No entanto, o fulcro dessa manobra propagandística, de acordo com Vale (2009), seria o uso do cientificismo a fim de garantir o refinamento da mão de obra e, por conseguinte, viabilizar o progresso tecnológico do país, tal como ambicionavam os protagonistas da industrialização.

Assumindo que a propaganda é inerente a todo e qualquer sistema educacional, o autor tomou para si a tarefa de realizar uma pesquisa que, "conduzida pela força da dialética, representa uma resistência ao uso instrumental e desumanizante das próprias ciências da educação" (p. 46). Uso este que consistiria em "ligar propaganda e educação a todos os objetivos que forçam as pessoas a buscar adesão, ou que unem pessoas em torno de uma causa que pode ser muito relevante para seus divulgadores" (p. 47 grifo do autor). Desse modo, Vale (2009, p. 47) estabeleceu que a Escola Nova teria criado, no Brasil, "um monstro em termos da vida social e educativa", notadamente pelo fato de que, sob o regime do Estado Novo, os líderes de tal movimento somente teriam abrigado ideias, técnicos e intelectuais, fossem nacionais ou estrangeiros, que auxiliassem na tarefa de sustentar o nacionalismo autoritário que então se implantava.

Na demanda por uma "contra-argumentação diante da educação domesticadora" (p. 48), o autor pretendeu tornar seu artigo uma peça de contrapropaganda. Por meio de uma perspectiva dialética, eliminando certa "concepção asséptica de educação", ele projetou um pensamento educacional que pretendia resgatar "o ponto de vista do proletário" e manter o permanente fluxo entre hegemonia e contra-hegemonia em nome da "complexa unidade de contrários: o fenômeno da educação e o fenômeno da propaganda" (p. 49).

Portanto, para Antonio Marques do Vale (2009, p. 43), o pensamento educacional deveria ser envergado no sentido de compreender que a "interpelação é premente e constante, exatamente porque brota do íntimo do sujeito". Dessa maneira, quando as demandas proletárias fossem contrapostas aos ideais burgueses, as práticas educacionais caminhariam em direção a alguma unicidade, desbravando, enfim, as sendas da humanização. Tal unidade, porém, seria concomitantemente precária - uma vez que fundeada no permanente movimento de construção e desconstrução - e completa, na permanente convicção de reconhecer o 
sentido real que subjaz a todo e qualquer conceito. Supomos que Vale (2009) estaria assumindo a função expertise do intelectual que conhece determinada realidade e luta para fazê-la aparecer, denunciando todos aqueles que não comungam com ela à condição de agentes da dominação e da ocultação.

A mesma perspectiva, que atribui ao pensamento educacional escolanovista posicionamentos intencionais, dinâmicos e unificadores, também compôs o cânone manejado pela visualização empreendida por Clarisse Nunes (1998) em seu artigo intitulado Historiografia comparada da escola nova: algumas questões. Preocupada em "identificar as representações que certas matrizes de pensamento, presentes nas reformas educativas, criaram para esses educadores com relação a seu próprio trabalho" (p. 106), a autora orientou seu olhar para dois campos que se apresentaram a ela como escoadouros dessas matrizes. $\mathrm{O}$ primeiro foi denominado histórico-sociológico e o segundo, psicológico.

À matriz histórico-sociológica, Nunes (1998) vinculou nomes como Silvio Romero, Anísio Teixeira e Fernando de Azevedo. Tais autores teriam criado suas representações a partir de teorizações advindas do universo jurídico. Por outro lado, os educadores abrigados em torno das matrizes psicológicas - entre os quais estariam Arthur Ramos e Afrânio Peixoto - fariam suas representações evocando conceitos do universo médico.

Após dissertar sobre tais contrários, Clarisse Nunes (1998) apresentou Lourenço Filho como aquele que teria sintetizado os sobreditos campos discursivos. Assim procedendo, o reformador teria incorporado "o papel do patologista social" (p. 109), ao reunir, no interior de sua análise sobre a escola, uma metade curativa a outra metade civilizatória, ambas apresentadas pelo pedagogo em termos de encargos necessários às práticas educacionais.

Destarte, voltando o olhar investigativo para a psique e, concomitantemente, para o meio social, Lourenço Filho teria fornecido condições para que se tornasse hegemônica uma concepção segundo a qual a escola deveria zelar pelos costumes e pela moralidade de seus pupilos. A sobreposição ideológica do educador, portanto, alijaria outras iniciativas educacionais, findando por fazer prevalecer representações cujos sentidos ainda hoje se manteriam nas práticas escolares. Recuperar as práticas dissonantes silenciadas pela historiografia seria a tarefa assumida pela pesquisa empreendida por Nunes (1998, p. 197), que, assim procedendo, desvelaria o "esforço ideologizador" levado a cabo por tal linhagem historiográfica.

Manter-se-ia, nessa concepção, o caráter elucidativo da pesquisa educacional e a ele se acrescentaria a voz dos dominados, em cujo cerne talvez estivesse a realidade subjacente às representações ideológicas. 
Afinado com esse desejo de desvelamento, Ronaldo Garcia (2006) estudou os embates que resultaram na extinção do Serviço de Ortofrenia e Higiene Mental operante entre 1931 e 1935 sob a liderança de Arthur Ramos e Anísio Teixeira. O referido serviço foi então tratado como uma iniciativa lastreada pelo projeto de "diminuir as diferenças sociais e desenvolver de fato a prática democrática” (p. 66).

Desse modo, Garcia (2006, p. 70) asseverou que ambos os reformadores "estavam preocupados em desenvolver a plena aplicação dos conhecimentos científicos na educação, ou seja, desenvolver mecanismos mais eficientes para aumentar o acesso à educação”. Contudo, supôs ele que a instalação do Estado Novo de Vargas teria entronizado "uma educação ideologizante" (p. 66), cujos desdobramentos teriam interrompido as pretensões dos higienistas da mente. Com o fechamento do Serviço de Higiene Mental, portanto, teria se desferido um forte golpe no encaminhamento de crianças com dificuldades de adaptação ao ambiente escolar.

Embora potencialmente democrática quanto ao acesso à escola - acesso viabilizado pelo olhar científico para os estudantes com dificuldades sociais ou cognitivas -, a higiene mental, segundo Ronaldo Garcia (2006, p. 75), guardaria algumas limitações, entre as quais a formação de "seres alienados e facilmente manipuláveis por ideologias de diversas naturezas". Nesse entendimento, portanto, o democratismo supostamente inerente à utopia higienista teria sido desvirtuado pelo autoritarismo estatal, tendo como efeito o engano e a despolitização.

A suscetibilidade a ideologias foi tema do texto $O$ resgate da Escola Nova pelas reformas educacionais, assinado por Roselane Fátima Campos e Eneida Oto Shiroma (1999). Dedicadas a compreender a manutenção de noções escolanovistas em ações reformistas - tais como o Relatório Jacques Delors, de 1998, os Parâmetros Curriculares Nacionais, de 1997, e as Diretrizes Curriculares para o Ensino Médio, de 1998 -, as pesquisadoras dirigiram seu foco analítico para questões como a função socializadora da escola; a centralidade do indivíduo e do processo de aprendizagem; a concepção da escola como mecanismo equalizador das desigualdades sociais; e a concepção da escola como lugar de aprendizado da democracia.

Tais aspectos comporiam o fulcro da crítica empreendida pelos escolanovistas aos métodos considerados tradicionais por seus promotores, crítica que se teria mantido na década de 1990. No entanto, um suposto "revival de teorias psicológicas" teria direcionado a potencialidade renovadora da Escola Nova para a "reativação da ideologia liberal" (CAMPOS; SHIROMA, 1999, p. 491) contida no movimento desde seu início, na década de 
1920. Desse modo, o caráter socializador da escola passaria a se limitar a práticas voltadas ao "desenvolvimento do indivíduo" (p. 486); a centralidade do aluno no processo de aprendizagem teria se restringido ao exercício de capacidades e competências; a utopia equalizadora teria sucumbido diante da meritocracia em nome da "igualdade de oportunidades" (p. 489); enfim, a afirmação do caráter democrático da escola teria cedido lugar a convocações para um hipotético espírito de competição e de sucesso individual.

Considerando esse quadro e na demanda por soluções, Campos e Shiroma (1999, p. 491) sugeriram que "se repõe para a escola, do ponto de vista do Estado, a tarefa de oportunizar o desenvolvimento das várias dimensões da personalidade dos indivíduos", a fim de eliminar do processo educativo o viés meritocrático e resgatar as conquistas daquilo que elas denominaram projeto moderno de escola, o qual restauraria as funções sociais, individuais, igualitárias e democráticas daquela instituição. Nessa perspectiva, os autores defenderam, como tarefa do Estado, o retorno às origens do escolanovismo, época em que o olhar para o desenvolvimento do indivíduo ainda povoava os sonhos redentores modernos.

Raquel Alvarenga Sena Venera (2009) também se ocupou das relações entre as heranças da Escola Nova e as ações estatais. Para tanto, evocando os métodos arqueológico e genealógico propostos por Foucault, dedicou-se a analisar os sentidos atribuídos aos “discursos de liberdade, autonomia, participação de todos, postura crítica" (p. 232, grifos da autora) nas reformas educacionais implantadas a partir da Lei de Diretrizes e Bases da Educação Brasileira, de 1996. Em sua empreitada, Venera (2009, p. 232, grifos da autora) interrogou acerca de qual "memória arquivo os professores brasileiros acessam para falar em liberdade, igualdade, criticidade e cidadania”. Ao fazê-lo, centralizou seu olhar nas relações entre educação e Estado, desde Comenius.

Aproximando-se de Comenius por meio de comentários feitos por Lourenço Filho, Venera (2009, p. 235) afirmou emergir desse encontro uma educação cujo princípio orientador alojar-se-ia em "ideias educacionais pautadas nos direitos iguais a todos os cidadãos". Daí teria surgido uma ligação que se manteria perene nos discursos estatais dirigidos à escola, operando em termos da responsabilização da instituição na garantia da unicidade do Estado. O mapeamento dessa ligação, de acordo com a autora, possibilitaria perceber a democratização anunciada pelas reformas educacionais pós-década de 1980 brasileira em termos de um "dispositivo para a construção de subjetividades cidadãs" (p. 239). Tal prática seria herdeira de um procedimento estabelecido desde Comenius e Rousseau, qual seja: a conexão definitiva de cada estudante aos interesses do Estado. 
Também interessado na incorporação do campo educacional pelo Estado brasileiro, Moisés Kuhlmann Júnior (2000) apontou sua mirada analítica para a preocupação que, historicamente, os diferentes governos tiveram com relação à educação infantil. Nesse aspecto, o autor observou que, "nas representações do país em eventos comemorativos" (KUHLMANN JR., 2000, p. 5), a crença no progresso da nação sempre esteve associada às imagens produzidas em torno da infância.

Partindo dos tempos escolanovistas, quando a ideia de criança era diretamente associada à "descoberta do Novo Mundo" (p. 8), o autor propôs uma história da educação infantil que tomasse como mirante as entidades de proteção aos infantes. Nesse trajeto, observou os efeitos das lutas ideológicas no plano do assistencialismo à infância durante a desmontagem do Estado militar pós-1964, focalizando, nesse processo, as bandeiras do movimento feminista para asseverar que "a luta pela pré-escola pública, democrática e popular se confundia com a luta pela transformação política e social mais ampla" (p. 11). Tal ambição política, segundo ele, estaria afinada à sua proposição de que o olhar para o desenvolvimento infantil, no intuito de afastar-se do abstracionismo, deveria considerar as "estruturas e práticas reais em que ocorre o processo educacional das crianças que frequientam as pré-escolas" (p. 17).

A partir dessa confusão e do permanente embate entre assistencialismo e educação pré-escolar, Kuhlmann Júnior (2000, p. 17) supôs a manutenção de práticas que alijariam o trabalho pedagógico da vida social dos educandos, o que redundaria em um regresso às vertentes escolanovistas que subordinavam suas práticas "à idéia de um desenvolvimento intelectual abstrato".

Portanto, fosse por meio do resgate do pregresso democratismo, fosse no otimismo atribuído ao desenvolvimento infantil, Venera e Kuhlmann Júnior associaram a necessidade de alastrar o direito público à educação tanto à fé no caráter progressista da escola, quanto à defesa do aterramento dela na vida concreta dos educandos. Essa última função ofereceria a possibilidade de devolver ao pensamento educacional sua concretude e o dirigiria de volta às aspirações populares.

O olhar abstracionista perpetrado pelo trabalho pedagógico, quando subordinado à cisão entre teoria e prática, foi também objeto de preocupação de Maurício Mogilka em seu artigo Educar para a democracia. Naquele empreendimento, o autor demonstrou sua preocupação quanto ao praticismo, este consubstanciado no grande risco em que incorreriam os produtores de currículos para os cursos de formação de professores no Brasil contemporâneo. 
Adotando um referencial marxista, Mogilka (2003) apresentou o que intitulou paradigma da prática reflexiva. Por meio de uma "concepção interacionista da escola [que] se apoia em uma concepção de sujeito que busca superar uma visão determinista de ser humano" (p. 135), ele retomou a filosofia de Dewey para asseverar que o processo escolar deveria abrir mão de modelos preestabelecidos e caminhar em direção a procedimentos voltados a "liberar, potencializar, expandir" (p. 137) os indivíduos a ele submetidos.

$\mathrm{O}$ autor atribuiu a Dewey um conceito radical de democracia, segundo o qual o próprio meio social formaria a base subjetiva da mencionada expansão pessoal. Assim, ao garantir um ambiente de "solidariedade entre as pessoas" (p. 140), os educadores poderiam apostar em uma "estruturação da autonomia das crianças" (p. 142), redundando na resistência ao pragmatismo irreflexivo e, por conseguinte, no distanciamento em relação à padronização dos comportamentos. Desse modo, espera Mogilka que a escola assuma a utopia democrática cujo cerne insere-se na certeza acerca da natureza livre e solidária das crianças. Tal vivência democrática preservaria a intimidade do acosso dos preconceitos sociais.

Acerca da escola como ambiente propício à reprodução de comportamentos padronizados, também dissertaram Fernanda Azevedo, Alexandre Bombassaro e Ticiane Vaz (2011). Em artigo que visou analisar a revista Estudos Educacionais, publicada entre 1941 e 1946, os autores se detiveram nas "práticas institucionais de educação do corpo" (p. 303), orientando seus focos analíticos na direção dos enunciados relativos à educação física.

Referida empiria permitiu-lhes sugerir que as ali veiculadas práticas discursivas voltadas aos corpos guardavam um projeto modernizador, de modo que, por meio de alocuções provenientes da sociologia, da psicologia e da biologia, implantar-se-ia um "esforço ideologizador" para que as instituições de ensino se envergassem em direção a uma "função disciplinar" da escola no sentido da "modelação de condutas" (AZEVEDO; BOMBASSARO; VAZ, 2011, p. 304). Tudo isso com o fito de atender aos interesses das indústrias sedentas de trabalhadores bem-formados e de cidadãos moralizados.

Nesse sentido, as convocações presentes na revista analisada evocavam, segundo os autores, práticas que distanciariam os pupilos do descontrole, enquanto convidavam os educadores/leitores a adotarem "uma metodologia para ensinar a viver, promovendo bons hábitos pelo esporte e edificando a personalidade do gentleman" (p. 310). Ou seja, dita revista propagandearia uma educação física moderna e disciplinar, “ortopédica e higiênica" (p. 309), condizente com os padrões ambicionados pela vida burguesa.

Também Diana Vidal (1998) voltou sua crítica para o caráter modernizador e padronizante da Escola Nova. Dedicada a analisar os caminhos que tomaram o ensino da 
escrita no contexto escolanovista, a autora sobrelevou o higienismo por ela visualizado quando observou o processo de substituição do ensino da caligrafia inclinada pelo da caligrafia reta. Tais modificações, que nos textos da época seriam justificadas tendo em vista a necessidade de se evitarem problemas de coluna e disfunções visuais, na análise da autora foram projetadas como signos de modernidade. Do mesmo modo, práticas orientadas à substituição da ardósia pelo papel na execução de exercícios caligráficos foram por ela analisadas como procedimentos civilizatórios. Vidal (1998), ademais, encontrou na opção escolanovista pela escrita muscular uma forma de disciplinamento que congregaria posturas higiênicas, pois sobrelevaria a velocidade e a eficiência com o propósito de produzir trabalhadores subordinados, ágeis e produtivos.

A construção de ações ortopédicas, disciplinadoras e conformadoras dirigidas à classe trabalhadora também foi tema para o artigo de Vera Marques (2003), que compilou enunciados pronunciados por cientistas brasileiros no século XIX a fim de demonstrar uma prática comum à época: a valorização do trabalho infantil como ortopedia social.

Sob tal enquadre, Marques (2003, p. 58) especulou sobre os efeitos da "permanência de uma cultura do trabalho infantil" na atualidade, cultura esta apresentada pela autora como característica do início da industrialização brasileira. Naquele tempo, ao final do século XIX, $25 \%$ dos operários têxteis eram crianças. Tal situação teria provocado uma bifurcação do discurso científico: enquanto os dizeres médico-sanitaristas condenavam o trabalho infantil, as emergentes higiene mental e medicina legal valorizavam-no como uma eficiente "ortopedia social” (p. 65).

Responsabilizada por erradicar a perambulação de crianças pobres pelas ruas das cidades industriais, a polícia era orientada no sentido de inseri-las em fábricas, constituindo aquilo que a autora denominou "Escola Premunitória" (p. 63), em que a tese do trabalho regenerador vigorava com intensidade. Essa conduta teria sido coerente com a hegemonização das classes dominantes, pois, no "imaginário burguês, a cidade moderna capitalista precisava apresentar-se plena de racionalidade, normalidade e disciplina" (p. 63).

Nesse sentido, Vera Marques (2003) discutiu a manutenção de tal lógica perversa na sociedade brasileira. Já na atualidade, a autora salientou um trato discriminatório em relação às crianças das classes empobrecidas, seja por meio da exclusão da cidadania, seja pela inserção dos infantes pobres em escolas de segunda categoria, dedicadas apenas a reforçar a cisão entre as classes sociais.

Assim, fosse por meio da modelação, da modernização ou da ortopedia, os autores referidos ativeram-se à exterioridade das práticas escolanovistas, fundamentalmente, 
relacionando o higienismo a um conjunto de imposições e contensões dirigidas aos infantes escolarizados.

A segregação social foi tema, ainda, do artigo de Cynthia Veiga (2000), que se dedicou a analisar o modo como os promotores do escolanovismo brasileiro relacionaram-se com a questão da raça. Partindo de pronunciamentos assumidos por eugenistas e higienistas mentais nas décadas de 1920 e 1930, a autora abordou a forma pela qual a questão da degeneração racial foi progressivamente se atrelando a enunciados dedicados a compreender a "ignorância atávica" (p. 129) dos elementos das camadas pobres. Muito além da exclusão por critérios puramente étnicos, os discursos médicos dirigidos à escola, segundo ela, afirmavam sua imprescindibilidade por meio da necessidade de "salvar um país doente" (p. 127).

Veiga (2000, p. 131) argumentou que tais práticas segregadoras teriam sido disseminadas pela Escola Nova em termos de uma perversidade: "da escola produtora das diferenças econômicas para a produção de diferenças de escolarização, por meio da seleção de alunos por suas aptidões naturais". Dita seleção produzir-se-ia nos procedimentos dos testes cuja operação levaria a uma "negação da cultura" (p. 142) dos subalternos, resultando na consequente reificação dos dominados ao submetê-los a padronizações cujos modelos investigativos escorar-se-iam em respostas produzidas pelo imaginário burguês.

Segundo a autora, foi utilizando essa perspectiva científica que a educação escolanovista ambicionou libertar-se do autoritarismo. No entanto, além de não realizar tal libertação, a Escola Nova teria findado por demandar "uma correção que viesse do interior" (p. 143) e garantisse, por conseguinte, o “direito biológico à educação" (p. 147), cuja operação incluiria "funções profiláticas e terapêuticas que dessem conta do controle subjetivo, através de normas cientificamente nomeadas pelos estágios do desenvolvimento infantil” (p. 143) - normas estas até hoje em operação na sociedade brasileira, sustentando "mentalidades segregacionistas" (p. 147).

Abordar a segregação racial em termos de "marcas profundas no inconsciente coletivo" (ARAGÃO, 2003, p. 171) também foi o empreendimento de Ediógenes Aragão. O autor compilou textos de viajantes, naturalistas e diplomatas que conheceram o Brasil no século XIX a fim de sopesar "as representações sociais e culturais do povo brasileiro, em nível nacional e internacional” (p. 153). Tais representações, nos dizeres de Aragão (2003, p. 167), seriam responsáveis por gerar "fraturas na construção da identidade nacional e de classe que iriam marcar a história da classe trabalhadora nos seus primórdios, inserida no processo de construção da nação" (p. 167), fraturas que agudizariam as consequências perversas do racismo. Muito além de uma recorrência do passado escravista, o preconceito racial operaria 
de forma a manter as desigualdades sociais, "emperrando a democratização das relações sociais" (p. 149).

A maioria dos artigos aqui elencados, quando tratam das alocuções biológicas dirigidas aos corpos dos alunos escolanovistas, abordam-nas em termos do hipotético preconceito burguês sobreposto às especificidades individuais. Essa abordagem raramente escapa da condenação à normalização empreendida por tais alocuções, mantendo portanto a crença na assimetria do saber científico e, por conseguinte, excludente.

Ao vasculhar, nos enunciados atribuídos aos pioneiros da Escola Nova, as inferências relativas à educação pública, João Carlos da Silva (2011) também concentrou sua análise na noção de um ideário excludente supostamente presente naquelas propostas. Em sua abordagem do escolanovismo como um movimento profundamente marcado pela "influência da cultura norte-americana pós-Primeira Guerra Mundial” (p. 529), o autor ressaltou a importância da Escola Nova - fundamentalmente após a incorporação das ideias de John Dewey - na desmontagem das "nefastas interferências do coronelismo na educação" (p. 530).

No entanto, apesar desse avanço, Silva (2011) criticou a opção dos escolanovistas por um caminho que teria afastado a educação brasileira do acolhimento das diversidades. Isso ocorreu, segundo ele, devido à submissão do escolanovismo a abordagens psicológicas, cujos efeitos teriam levado a educação a restringir seus procedimentos a uma suposta função adaptativa. Tais abordagens teriam, assim, limitado o olhar dos especialistas à observação acerca das aptidões dos adolescentes, instigando-os a condutas "que representam as únicas forças capazes de arrastar os jovens à cultura superior” (p. 536). Tal superioridade seria posta a serviço da "instauração de uma ordem social burguesa-industrial” (p. 537) no país.

A perspectiva comum à maioria das análises até aqui compiladas apresenta os primeiros tempos da Escola Nova como uma época que abrigava utopias de diferentes tipos. No último caso, é do respeito à diversidade que se trata, respeito este eliminado pela ascensão da hegemonia burguesa, assim como a quase totalidade das benesses escolanovistas.

O tema da ligação entre educação e imposição cultural também foi abordado por Jacques Gleyse e Carmen Lucia Soares (2008). Ao estudarem imagens de mulheres projetadas em manuais franceses de educação física produzidos no século XIX e no início do XX, os autores visualizaram tais enunciados em termos de um "estereótipo de gênero que finalmente pode ser pensado como uma modalidade de controle dos corpos" (p. 145). Tal estereotipia teria contribuído para propagar mitos cuja operação associaria a feminilidade a atributos como fraqueza, passividade, invisibilidade, suavidade, maternidade, enfim, todo um campo discursivo dedicado a irradiar modelos de comportamento por meio da "naturalização do 
gênero" (p. 149). Destarte, respondendo positivamente à pergunta a que eles próprios se propuseram - "seriam os manuais escolares que tratam do exercício físico sexistas?” (p. 153) -, os autores afirmaram flagrar uma suposta aprendizagem da discriminação, presente na lida educacional desde a alvorada do século XX.

Também dedicado a inventariar representações produzidas nos discursos acerca das práticas corporais desenvolvidas nos tempos da Escola Nova, Carlos Cunha Junior (2011) analisou o jornal $O$ Pharol, publicado em Juiz de Fora desde 1870. A partir de sua compilação da dita fonte, foi-lhe possível dissertar sobre a identificação das práticas corporais com “símbolos de modernidade" (CUNHA JÚNIOR, 2011, p. 54) supostamente presentes naquela publicação. Dessa forma, a instigação à “disputa, velocidade, comparação de resultados” (p. 58) contemplaria a "vertente de um projeto médico-higienista" (p. 56) com as funções de "controle social, de regeneração/aperfeiçoamento da raça, de construção/inculcação de um sentimento de identidade nacional, de desenvolvimento e aprimoramento do físico e da saúde" (p. 56).

Igualmente preocupada em sopesar a presença do discurso higienista na base de enunciados dirigidos à educação brasileira no princípio do século XX, Liane Martins (2003) dedicou-se a analisar os dizeres dos especialistas que depararam com a epidemia de gripe espanhola no Brasil de 1918. Após investigar falas de eminentes médicos da época - seus reclamos ao Estado; suas preocupações quanto ao caráter nacional da enfermidade; suas determinações em termos de circulação, repouso e preservação das populações urbanas -, a autora concluiu que a reunião de todas as diferentes iniciativas para contenção do temível mal localizava-se em apenas uma ação: a generalização das práticas educativas.

Tais práticas, segundo ela, para além de recorrerem à segregação e ao extermínio dos doentes, apontavam para a necessidade de garantir um convívio adequado e salubre no sentido da “construção da São Paulo Metropolitana” (MARTINS, L., 2003, p. 113). Destarte, contra a influenza, uma "doença sem remédios" (p. 114), os higienistas teriam sugerido aos educadores a regulação dos hábitos de seus pupilos.

Na linha da precedência da urbanidade nas evocações escolanovistas, Marlene Ribeiro (2013) criticou as atuais políticas educacionais, fundamentalmente quando elas se dirigem ao trato com as populações camponesas. Analisando o Programa Escola Ativa (PEA), implementado pelo governo brasileiro em 2009, a autora sugeriu nele a retomada de princípios antipopulares presentes na concepção escolanovista. O próprio nome do programa guardaria resquícios do pensamento de Dewey, cuja conceituação desprezaria a luta de classes e impediria a unidade entre trabalhadores rurais e urbanos. Nesse sentido, contra o 
conservadorismo que atribuiu ao escolanovismo, Ribeiro (2013, p. 675) defendeu uma educação do campo "articulada ao trabalho como definidor do humano dentro de um projeto societário popular que inclua os agricultores enquanto sujeitos produtores de bens e conhecimentos".

Quando os pesquisadores até aqui compilados utilizam o termo ideologia, fazem-no quase sempre na pretensão de dizer palavras revolucionárias: emancipação como norte, humanização no horizonte, proposições orientadas ao futuro. Insinuam a libertação dos camponeses, das mulheres, dos dominados, dos deficientes, das crianças, dos jovens, dos alunos e dos limitados. Libertar para encaminhar - à democracia, à autonomia e ao desenvolvimento.

Ao tomarem as relações escolares pelo viés ideológico, tais autores coletaram leis, números, depoimentos, propagandas, teorizações, métodos, exercícios, avaliações. Em quase todos os seus objetos, encontraram imposições, segregações, simbologias, significações, representações.

Dedicaram-se a flagrar infinitas manipulações: dos psicologismos aos sociologismos, do higienismo e da burocracia à organização do trabalho. A superação das representações que entravavam a libertação dos explorados foi a meta a que se dirigiram tais críticos das ideologias.

Descortinar representações para superar antigas práticas; denunciar todas as ortopedias, os testes, os controles, as obrigações; instituir novos procedimentos por meio da racionalização das soluções, do insuflar dos desejos, do respeito absoluto à individualidade, do perfeito ajuizamento dos conflitos e dos rendimentos; extinguir toda forma de apartação, seja ela racial, moral ou etária: um doce sonho para autores que encontram no mundo apenas a falsificação, a violência dos símbolos, o monopólio das palavras, dos gestos, dos subterfúgios.

Ver o mundo como ideologia seria nele projetar a crença em um permanente estado de engano. Para tais pensadores, o mundo é ilusão constante. Os jogos dos contrários sociais apenas se envergariam à burguesia. Também segundo eles, aos conscientes bastaria a crença na marcha perene do proletariado, pronto a emergir das mentiras históricas em direção ao estrelato revolucionário. Um lindo futuro em que, finalmente reconciliados todos os inimigos dos pobres, um novo tempo se anunciaria. 
Para os autores que utilizam a visualização pelo viés ideológico, os procedimentos da Escola Nova seriam explicados em termos de sua cumplicidade com o espraiamento dos ideais burgueses em direção às classes subalternas. Vejamos agora textos que adotam uma teorização diversa de tal abordagem ideológica.

É o caso do artigo intitulado Educação para inteireza do ser, de Marco Luiz Pozatti (2012), que tratou das relações entre subjetividade e conhecimento. Em sua empreitada, o autor procurou conectar educação e saúde, com o objetivo de confeccionar um olhar crítico e propositivo acerca da educação atual. Para tanto, partiu de elementos de sua própria formação acadêmica, ressaltando sua adesão aos movimentos sociais que, durante a década brasileira de 1970, preocupavam-se com a vida de comunidades carentes, no que tange tanto à saúde quanto à educação.

Narrou Pozatti (2012) que, ao entrar em contato com as vivências comunitárias dos populares, voltou seu olhar para as práticas alternativas de saúde que tais comunidades realizavam. A partir daí, afirmou desenvolver uma consciência de si que lhe teria permitido asseverar que, "para desenvolver-se plena e saudavelmente, o ser humano necessita, ao ampliar sua consciência, harmonizar-se e realizar uma reconexão transcendente com a Totalidade" (p. 156).

Tal visão holística da vida e da educação levou-o a defender o acréscimo de mais um aos já conhecidos pilares propostos pelo Relatório Delors acerca da educação para o futuro. Em sua visão, dever-se-ia incluir o "aprender a amar" (p. 155) nas preocupações mundiais sobre a educação do segundo milênio, de modo a criar "uma educação para a inteireza do ser, contribuindo para uma educação e cuidado humanos que incluam o si mesmo, o outro, o planeta e sua conexão com o Universo" (p. 144).

Em consonância com Pozatti (2012), Ivani Fazenda e Fernando César de Souza (2012) também centralizaram suas análises na relação dos alunos consigo mesmos no processo de aprendizagem. A partir de um posicionamento expresso pela questão "somos capazes de criar vínculos de cuidados na disciplina que lecionamos, na compreensão de quem sou e de quem são meus alunos?” (p. 113), os autores especularam sobre uma concepção de educação capaz de aproximar procedimentos educativos a práticas de cuidado.

Retomando referências gregas presentes no mito de Asclépio e na filosofia de Filon de Alexandria, eles sugeriram que se deveria "valorizar o princípio da cura como cuidado na valoração de uma educação para a paz" (p. 112). Assim, sustentaram, seria possível cumprir as evocações presentes no Manifesto Educação para a Paz, instituído pela UNESCO em 2000. 
Destarte, Fazenda e Souza (2012) aventaram a possibilidade de instituir uma escola voltada à terapêutica, em que a relação educativa mimetizaria o "olhar de uma mãe que acalenta seu filho, mas que também permite o florescimento de sua identidade e seu posicionamento como vivente no exercício de humildade, não de subserviência" (p. 112). Por fim, os autores recuperaram a denúncia de Paulo Freire em relação à "cegueira do saber de uma educação bancária" (p. 119, grifo dos autores) evidente nas propostas tecnicistas dirigidas ao processo de ensino-aprendizagem, as quais, assim como nos tempos da psicometria escolanovista, limitar-se-iam à exterioridade do aluno e não permitiriam acesso à sua interioridade, esta sim apta a levá-lo à ação reflexiva.

A suposição de uma educação que curasse por meio do despertar de um olhar dirigido de si para si mesmo também foi ponto de partida para que Ana Maria Teles e Teresa Cristina Cerqueira (2013) discorressem sobre as relações entre subjetividade e aprendizagem. Tais relações, segundo as autoras, deveriam contemplar uma perspectiva "que permita a emergência do aprendiz como sujeito de si e de seu aprendizado, de sua prática posterior, assim como do mundo em que vive e compartilha" (p. 933).

Recorrendo à epistemologia qualitativa, Teles e Cerqueira (2013) realizaram uma investigação com alunos de um curso a distância sobre de biocinética bucal. Dedicadas a compreender "como despertar o sujeito" (p. 936), constituíram um raciocínio baseado numa

[...] percepção da postura humana como sendo parte de um todo integrado no qual a boca seria um subsistema que deve ser trabalhado como parte do sistema maior biológico e fisiológico, que por sua vez é compreendido como parte de um todo ainda maior simbólico e emocional, que ainda deve ser considerado como integrante de sistemas sociais cultural e historicamente constituídos (p. 938).

Esse caráter concêntrico atribuído à postura humana seria, segundo as autoras, suficiente para escorar o preparo de indivíduos capazes de livrarem-se de todas as formas de padronização tradicionalmente instituídas por um olhar médico puramente voltado ao conteúdo técnico dos procedimentos terapêuticos.

A crença na centralidade de um ser que se vincularia, de modo progressivo, à sua própria fisiologia e, por extensão, à sua história permitiu que as autoras especulassem sobre uma educação fundada no "despertar da consciência", capaz de enfrentar a passividade e transformar o indivíduo em "sujeito de seu corpo" (p. 945). Uma pedagogia do si mesmo na qual "aprender é transformar-se" (p. 949), no sentido de produzir estratégias pessoais habilitadas a prevenir o indivíduo tanto de doenças quanto de agressões à sua liberdade. 
A educação para inteireza do ser aventada por Pozatti (2012) e a educação terapêutica insinuada por Teles e Cerqueira (2013) estão em consonância com o modo como Francisco Moura e Talitha Silva (2009) dirigiram seus olhares para as dimensões holísticas e clínicas que suspeitaram presentes no movimento pela Escola Nova.

Ao pesquisarem sobre as práticas escolanovistas, eles ativeram-se à centralidade concedida ao aluno no processo de ensino-aprendizagem. Considerando dita centralidade como atenção à subjetividade, Moura e Silva (2009) defenderam que tal atenção comporia um importante sustentáculo no qual se poderia apoiar a dimensão clínica da educação. Ao “despertar o desejo pelo saber no aprendiz” (p. 269), a Escola Nova teria criado possibilidades para aplicar métodos que estivessem dirigidos especificamente às subjetividades e, por conseguinte, garantissem a adequada "ênfase no sujeito implícito por detrás de cada indivíduo" (p. 267).

Assim, aplicando a psicanálise ao processo educacional, os autores indicaram que o professor, para promover a salubridade de seus pupilos, deveria ater-se - tal como os pregressos escolanovistas - à posição de facilitador do aprendizado, permitindo que seus alunos desenvolvessem de modo livre os caminhos para sua própria subjetivação. Uma aprendizagem que permitiria, pois, diagnosticar anormalidades, encaminhar tratamentos e, antes de tudo, recomendar comportamentos preventivos.

Entre os artigos sobre os quais nos debruçamos, numerosas são as análises semelhantes às de Moura e Silva (2009), no sentido de evocarem uma perspectiva diferente daquela utilizada pelos rastreadores de ideologias. Tais especulações, aventamos, propõem-se a reposicionar o olhar dirigido às invenções escolanovistas, abdicando da mirada que nelas vislumbraria sempre manipulações e preconceitos.

Em posição diametralmente oposta estiveram os autores que vislumbraram na Escola Nova as bases para uma educação clínica. Nessa perspectiva, cuidado, transcendência e otimismo deveriam se fundir para promover a efetiva transformação dos educandos em sujeitos. Adequadamente integrados à forma sujeito, os infantes abrigariam em seus corpos e em suas almas a possibilidade de ativamente conduzirem toda a humanidade a um ambiente de paz.

A partir desse deslocamento de olhar, a educação voltada para dentro, tal como projetaram os escolanovistas, seria revigorada em termos de um processo educativo devotado ao cuidado e à religação de cada indivíduo ao sujeito localizado em sua própria essência individual. Para além da manipulação ideológica, a Escola Nova teria oferecido elementos para que o ato de ensinar pendesse para ações de preservação e cura. 
Há ainda outro grupo de artigos, distintos tanto daqueles que adotam teorizações clínico-terapêuticas, quanto dos que lançam um olhar ideológico para a Escola Nova. Trata-se de produções que, amiúde, parecem sustentar releituras dos pensamentos de John Dewey, Anísio Teixeira, Arthur Ramos e Paulo Freire, entre outros, no sentido de visualizar o escolanovismo como um repositório de práticas promissoras e, ainda hoje, reformadoras. Tais artigos, em bloco, associam a aversão deweyana à psicometria com seu profundo democratismo; por conseguinte, parecem propor que uma mudança no olhar para a psique púbere levaria a uma educação que cumprisse um papel edificante na constituição dos educandos como sujeitos e protagonistas de sua própria aprendizagem.

Karen Bortoloti e Marcus Vinicius Cunha (2013) ponderaram o papel de Anísio Teixeira na instalação de um cariz democrático para o escolanovismo. Conforme os autores, o uso feito por Teixeira dos pensamentos de Dewey teria afastado o educador brasileiro dos excessos provocados pela psicometria de seu tempo.

Bortoloti e Cunha (2013, p. 44) asseveraram que, para Anísio Teixeira, as medidas dos testes deveriam ser usadas para reconhecer as "potencialidades de cada pessoa e o seu consequente posicionamento em uma função social”. Opondo-se a Lourenço Filho, Teixeira teria optado pelo "progressivismo pedagógico" (p. 39) de Dewey, o que lhe permitiria amparar um projeto educacional em potencialidades individuais cujo aprimoramento instituiria um modo de vida em que a ideia de progresso estaria associada à prática da democracia, esta instigada pela escola.

Segundo Cunha (1996), tal modo de vida deveria ser cultivado, já na infância, por meio de uma educação que garantisse a adequação e a atuação cooperativa da criança em seu meio social. Agora interessado em relacionar as concepções pedagógicas de Dewey e Piaget, o autor imergiu nas discussões realizadas pelos pedagogos escolanovistas em torno do embate entre o ensino tradicional e o ensino renovado. Nesse aspecto, Cunha (1996) deu destaque para as diferentes maneiras pelas quais esses dois modelos educacionais se propunham a realizar a transmissão de conteúdos. Segundo ele, a Escola Nova teria entronizado princípios contrários à centralidade do conteúdo na organização do ensino, de modo que o educador formado sob os cânones escolanovistas deveria voltar seu olhar atento para as aptidões dos educandos, sempre com o foco direcionado às suas experiências e aos seus interesses. 
Destarte, utilizando suas reflexões acerca da obra de Dewey, Marcus Vinicius Cunha (1996, p. 8) asseverou que instruir, na perspectiva deweyana, seria "reconstruir, no espírito do educando, respeitada sua peculiaridade, a experiência histórica do saber humano contida nas ciências". À luz dessa concepção sobre instrução e cotejando ideias atribuídas a Piaget, o autor chegou à seguinte máxima: educar é socializar. Assim, sugeriu que, ao permitir a supressão do eu egocêntrico pelo eu social, a educação cumpriria sua tarefa no encaminhamento de um desenvolvimento individual que credenciaria ao educando uma vida social promissora.

Tal desenvolvimento deveria ser suficiente para que a criança fosse encaminhada "para uma vida social em que prevaleça a razão coletivamente construída" (p. 11), razão esta que, quando devidamente abrigada na escola, configurar-se-ia na expressão da liberdade de cada qual dos indivíduos e abriria espaço para o necessário convívio democrático. O caráter preponderantemente socializador da escolarização seria fulcral, segundo Cunha (1997), para compreender as relações que os escolanovistas atribuíam à educação familiar. Ainda, apontou o autor que a desqualificação da família para educar teria sido um mote constante no ideário da Escola Nova.

Baseados na concepção de que somente o professor estaria cientificamente preparado para administrar uma efetiva educação, os educadores escolanovistas compilados por Cunha (1997) teriam procedido a um sistemático deslocamento das responsabilidades pela educação: da casa para a escola. Tal rearranjo foi, segundo o autor, muito mais penetrante e permanente do que o olhar sobre os "particularismos da vida psíquica" (p. 53). Ele observou, assim, que as reflexões sociológicas teriam gradativamente se sobreposto às análises psicológicas.

Nessa perspectiva, apesar de a psicologia ter se tornado uma ferramenta bastante útil para as intenções dos escolanovistas, dita ciência não teria procedido a uma investigação profunda das influências familiares sobre os educandos. Reparou Cunha (1997) que a maior parte dos escolanovistas por ele investigada teria focalizado o papel das famílias apenas em termos de influências exteriores, raramente se aprofundando na sondagem de mecanismos psíquicos envolvidos nas tramas parentais. Esse enfoque, segundo ele, afastou as práticas escolanovistas de uma suposta psicologia da vigilância; assim, desviando-se de um tal psicologismo individual e policialesco, as referidas práticas, quando inspiradas em Dewey, teriam referenciado os aconselhamentos escolares nas próprias experiências sociais dos educandos.

Cunha e Souza (2011), em sua análise da contribuição de Cecília Meireles para o movimento da Escola Nova, ratificaram tal pretensão escolanovista de antepor a educação 
social à educação psicológica. Ao considerarem o papel político por ela assumido no contexto de instalação dos princípios escolanovistas, assumiram que a literata defendia que "a instituição de ensino deveria ser um ambiente de vida" (p. 859); uma vida em que "a saúde, a estética e a moral, correspondentes às faculdades e possibilidades que se podem encontrar na criatura humana" (p. 858), seriam cultivadas na escola, cuja responsabilidade não deveria ser a de curar, mas sim a de educar. Daí tal educação dever se direcionar "à constituição da estrutura psíquica das pessoas" (p. 862).

Para Cecília Meireles, segundo Cunha e Souza (2011), o escolanovismo propunha uma educação humanizadora e socializadora que, por meio de uma simbiose com as práticas artísticas, configurar-se-ia em poderoso instrumento para ativar o interesse das crianças e potencializar suas faculdades.

Ainda conforme os estudos de Marcus Vinicius Cunha (1999a), esse caráter, ao mesmo tempo, humanizador e potencializador da Escola Nova estaria presente nos escritos de Dewey. De acordo com tal abordagem, o pedagogo norte-americano deveria ter sua obra revisitada, particularmente no que tange às questões relacionadas a possíveis conexões entre ciência e pedagogia. Segundo o autor, para Dewey, a educação deveria ser assunto dos estudos de cultura, antropologia, economia, ecologia, psicologia, biologia, política e moral, de tal forma que as questões propriamente psicológicas - centro das discussões escolanovistas lideradas por Lourenço Filho - perderiam espaço diante de uma tal compreensão ampliada da noção de humano/educando.

Cunha (1999b), no que concerne às ideias deweyanas quanto ao intercâmbio entre ciência e educação, apontou para a existência de uma tradição na literatura pedagógica brasileira e internacional que associaria Dewey a um cientificismo estreito e profundamente experimentalista. As referidas análises sugeririam uma suposta "ausência perversa da Filosofia" (p. 79) nos escritos do autor estadunidense.

Entretanto, o esforço analítico de Marcus Vinicius da Cunha (1999b) dirigiu-se à refutação do alegado desprezo de Dewey pela filosofia. Para o autor, o pensamento deweyano faria muito mais do que incorporar a filosofia em suas teorizações; ele integraria o gesto filosófico à ciência por meio do conceito de experiência. Este carrearia consigo a única “convivência humana aceitável” (p. 81), qual seja: a democracia. Ademais, o exercício democrático levaria a "um modo de vida em que o homem pudesse desenvolver plenamente suas potencialidades" (p. 81).

A democracia, para Dewey, tornar-se-ia, assim, "um meio capaz de revelar o sentido da existência humana" (p. 90). Uma existência livre e cooperativa na qual a conexão das 
ciências, tanto as sociais quanto as psicológicas, formularia um posicionamento político antiliberal. Dessa forma, o educando poderia experimentar todas as suas potencialidades humanas, sempre no sentido de viabilizar a "formação de atitudes intelectuais e sentimentais perante a natureza e os homens" (p. 82). A natureza aí concebida seria não "um bloco de dons oriundos da bondade divina ou da essência imutável do ser humano" (CUNHA, 2001, p. 380), mas "essencialmente social" constituída, entre outros elementos, "pela experiência de cada indivíduo neste mundo" (p. 379).

Caberia à escola, portanto, o compromisso com a criação de uma educação planejada e intencionalmente dirigida para garantir aos aprendizes experiências que, em liberdade, leválos-iam a viver de maneira democrática e, consequentemente, a melhorar "a experiência atual e futura da humanidade" (p. 382), no sentido da construção de "uma sociedade mais humanizada" (p. 384).

Muitos autores aqui reunidos sobrelevaram a importância de Anísio Teixeira na concepção dessa missão humanizadora do democratismo. Esse foi o caso de Heloisa Santos (2000), que, ao estudar o Ideário pedagógico municipalista de Anísio Teixeira, estabeleceu uma biografia que apresenta Anísio Teixeira como educador, homem de ação, administrador, intelectual, conselheiro, reitor e tradutor, sempre dedicado à defesa de uma educação popular, crítica e, fundamentalmente, descentralizada. Segundo a autora, tais elementos teriam possibilitado a vitória de todos aqueles que, em 1934, defenderam a inserção de princípios democráticos na legislação constitucional promulgada naquele ano.

Entre esses princípios, Santos (2000, p. 111) compilou "a obrigatoriedade e a gratuidade do ensino primário; o direito de todos à educação; a obrigatoriedade do ensino gratuito; a instituição da unidade, descentralização e autonomia dos serviços de ensino público". Assim, a atuação de Anísio Teixeira teria inspirado ideais de longa duração na história da educação brasileira e, por conseguinte, mantido uma filosofia voltada à defesa da formação de comunidades equânimes quanto às oportunidades e aos acessos a todos aqueles que pretendessem criar uma sociedade democrática a partir da escola.

Tal atenção à educação pública integrada ao meio social foi o mote a partir do qual Darcísio Muraro (2013) pretendeu relacionar o pensamento de Dewey às concepções pedagógicas de Paulo Freire, que teria se utilizado do pensamento deweyano para reorientar o viés psicopedagógico do escolanovismo em direção a um viés político-pedagógico, este tributário do pensamento de Anísio Teixeira.

Conforme discorreu Muraro (2013, p. 818), Freire partia da ideia de que a educação deveria assumir-se como um processo reflexivo cuja atividade estaria centrada no "ato de 
pensar na experiência”. Desse modo, somente refletindo sobre sua própria ação poderia o educando/cidadão modificar sua própria realidade e preparar-se para resistir à exploração e à alienação provocadas pelo sistema capitalista.

O princípio da democracia como modo de vida, segundo Muraro (2013), uniria as ideias de Dewey e Freire. Para o último, a vida democrática deveria ser garantida por uma educação libertadora segundo a qual a realidade exterior à escola seria mote para problematização e consequente conscientização dos educandos, que utilizariam os conteúdos escolares como motivos para sua luta ética contra toda forma de pensamento de segunda mão. Assim, ativada na escola, a inteligência se tornaria "o instrumento socializador por excelência" (p. 827), podendo a escola então "propiciar um ambiente favorável para que cada indivíduo tenha possibilidade de desenvolver sua natureza potencialmente social” (p. 828).

Essa responsabilidade potencializadora da inteligência e, concomitantemente, humanizadora atribuída à instituição escolar é tema recorrente em alguns dos artigos compilados. Tal como nos escritos constantes na Bibliotheca de Educação, o meio social aqui comparece como fator constitucional do psiquismo. Essa incorporação da exterioridade pelo aparato psíquico, tanto na atualidade quanto há mais de 50 anos, foi compreendida em termos de desenvolvimento da inteligência.

Newton Duarte (1998, p. 85), confrontando o ideário escolanovista com as acepções de Lev Vygotsky, chegou a uma concepção segundo a qual "o trabalho educativo é o ato de produzir, direta e intencionalmente, em cada indivíduo singular, a humanidade que é produzida histórica e coletivamente pelo conjunto dos homens".

Na tentativa, ao longo da história da educação, de se realizar essa tarefa humanizadora, Duarte (1998) localizou dois princípios cuja distinção localizar-se-ia no posicionamento do professor durante o ato de ensinar. O primeiro deles seria definido pelo autor como negativo, pois em alguma medida desconsideraria a preponderância do professor no estímulo ao desenvolvimento do aluno. À linhagem negativa pertenceriam tanto os modelos anunciados como crítico-reprodutivistas, quanto os denominados construtivistas. Os primeiros, segundo Duarte (1998), relativizariam a importância do professor por considerarem que nenhuma verdadeira transformação ocorreria na escola enquanto não se transformassem as relações de produção na sociedade. Já os construtivistas seriam excessivamente apegados ao modelo biológico proposto por Piaget e, portanto, atribuíam demasiada importância à maturação intelectual diante da atuação do professor.

Nesses dois princípios negativos, Duarte (1998) localizou heranças das práticas escolanovistas. A positividade do ato educativo, segundo o autor, estaria presente nos 
procedimentos inspirados nas teorias histórico-críticas. Estas, escoradas na psicologia histórico-cultural inspirada nas teorizações de Vygotsky, sobrelevariam o papel do professor e, por conseguinte, do meio social no estabelecimento de uma zona de desenvolvimento proximal suficiente para estimular a cognição do educando. Assim, afastados do negativismo pedagógico, os professores histórico-críticos não aceitariam a "aprendizagem por si só" (p. 103) presente nas concepções de alguns autores da Escola Nova.

Uma educação intencional e humanizadora, conforme proposta por Duarte (1998), apostaria na progressiva constituição de um conjunto de estruturas cognitivas que seriam, ao mesmo tempo, ação de si sobre si mesmo, porém produto da ação externa, racional, científica e, portanto, liderada pelo professor. Tal intencionalidade - nas análises dos autores do artigo intitulado Pragmatismo e desenvolvimentismo no pensamento educacional brasileiro dos anos 1950/1960 (MENDONÇA et al., 2006) - foi atribuída a um posicionamento político bem claro.

Ao analisarem a documentação publicada pelo Instituto Nacional de Estudos e Pesquisas Educacionais (INEP) e pelo Instituto Superior de Estudos Brasileiros (ISEB), os pesquisadores identificaram duas perspectivas presentes nas diferentes definições estabelecidas por tais documentos. Trataram ditas perspectivas em termos de pragmatismo e desenvolvimentismo. No primeiro caso, encontraram discursos que criticavam a associação entre a educação e a própria vida, atribuída a algumas leituras de Dewey. Em se tratando do desenvolvimentismo, localizaram um viés bastante progressista. Sobretudo com relação às conceituações de Anísio Teixeira acerca do progressismo deweyano, Mendonça et al. (2006, p. 107) depuraram uma concepção de educação cuja atuação "poderia ser orientada não só no sentido do desenvolvimento econômico, como também no sentido da consolidação do modo de vida democrático".

O itinerário que parte das ações escolares, atua sobre a cognição dos estudantes e os credencia a viver de maneira democrática também foi tema para um artigo dedicado a analisar o pensamento de Euclides Roxo e suas propostas na área da educação matemática (CARVALHO et al., 2000). Os autores sobrelevaram a preocupação do escolanovista Euclides Roxo em promover uma educação matemática na qual os alunos ocupassem o centro do processo de aprendizagem. Dessa forma, por meio do estímulo aos interesses dos aprendizes, da excitação de sua curiosidade e da luta contra a passividade deles, Roxo teria aproximado definitivamente os métodos de ensino ao contexto e, por conseguinte, à própria vida dos estudantes. 
Carvalho et al. (2000) asseveraram que Roxo teria se afastado do psicologismo estreito que, durante muito tempo, seria a marca da Escola Nova, conforme argumentaram os críticos ao movimento. Assim, os procedimentos do matemático atingiriam efetividade na medida em que estivessem adequados ao estágio de desenvolvimento de seus pupilos. Portanto, a matemática aplicada por Roxo consideraria que "o ser humano estaria na escola para desenvolver suas potencialidades, a sua inteligência, e utilizá-la na sua vida, fora da escola" (p. 422).

Uma relação com o conhecimento que estimularia as capacidades cognitivas e, por conseguinte, instituiria determinado convívio social foi o tema central do artigo de Itamar Freitas (2007). Em seu texto, o autor dedicou-se a analisar as contribuições do historiador escolanovista Cesário Junior no sentido de reconhecer em seus métodos a especificidade estabelecida pelo movimento no que tange ao ensino da História. Reparou Freitas (2007) que os princípios da Escola Ativa - tal como estabelecidos por Lourenço Filho, entre outros instigavam os professores a se afastarem do modelo mnemônico quando aconselhavam métodos para o ensino da mencionada disciplina.

Esse estímulo às capacidades, conforme aplicado por Cesário Junior, foi tomado por Itamar Freitas (2007) como indício de que, nos tempos de ascensão da Escola Nova, teriam sido criadas condições para se estabelecer um olhar específico sobre o papel desempenhado pela escolarização. Segundo o autor, o ensino - particularmente o de história - teria como função instigar os estudantes a aplicarem procedimentos de "análise, síntese, comparação, observação, descrição, debate, identificação de semelhanças e diferenças etc.” (p. 174), ou seja, metodologias semelhantes àquelas que desenvolvem os historiadores em sua prática acadêmica.

Desse modo, supôs Freitas (2007) que os princípios escolanovistas aplicados para aprimorar métodos e habilidades dos aprendizes estariam na base das atuais propostas de instalação de uma escola promotora da vida cidadã. Tal intento seria efetivado no momento em que alcançassem sucesso práticas voltadas ao estímulo da "atividade mental e física" (p. 170), quando se pretendesse garantir ao educando segurança e racionalidade na tomada de decisões.

Os pesquisadores que abdicaram dos vieses ideológico e terapêutico visualizaram a Escola Nova como momento em que perspectivas antropológicas, sociológicas, políticas, psicodesenvolvimentistas, autonomistas, humanistas, pedagógicas, igualitárias ou democratas teriam emergido como contraponto ao tradicionalismo e ao empirismo que, segundo eles, caracterizavam a educação tradicional. Na medida em que contrapuseram antropologia a 
segregação, sociologia a psicologismo, política a alienação, construtivismo a psicometria, autonomia a padronização, humanismo a desnatureza, pedagogia a inconsistência, igualitarismo a elistismo, democracia a autoritarismo, tais autores constituíram análises em que as críticas à Escola Nova sucumbiam diante da proposta aparentemente redentora do momento.

Para esse grupo de autores, os visualizadores de ideologia sugeriam que, diante do quadro da burguesia ascendente e da consequente opressão capitalista, recorria-se à educação pública a fim de confinar, controlar e adestrar os infantes das classes dominadas. Negando tais visualizadores, os defensores de Dewey, Teixeira ou Freire observavam aquela mesma época como momento em que o progresso, a liberdade e a democracia se amalgamaram para sugerir a constituição de modos de vida em que a potência individual conquistaria sua máxima expressão.

Em consonância com os clínicos, os autores dedicados a reabilitar o caráter progressista da Escola Nova recorreram ao destacado democratismo que o movimento abrigou. Reagindo contra as acusações dirigidas ao psicologismo supostamente presente nas práticas escolanovistas, tais pesquisadores democráticos também adotaram uma perspectiva otimista diante das invenções da Escola Nova.

$\mathrm{Na}$ releitura de pedagogos progressistas, encontraram em suas teorias propostas de redenção, tanto dos púberes quanto de toda a humanidade, a partir da vivência escolar. Com base na série experiência/socialização/democracia/existência humana, puderam eles amalgamar a crítica social contida no pensamento contraideológico à formação do sujeito indicada pelos clínicos. Conforme esse viés analítico, a escola deveria retomar seu papel de um lugar de vida em que o respeito às individualidades garantiria o desenvolvimento da inteligência, cuja potencialização, por sua vez, levaria a posturas reflexivas e produziria cidadãos autônomos e éticos, ou seja, seres humanos íntegros.

Além dos olhares ideológico, terapêutico e progressista-democrático, há no conjunto de artigos compilados uma quarta perspectiva. Esta centra seu foco no fato de que, desde o século XIX, saberes dirigidos à infância e à sua educação poderiam ser analisados em termos da constituição de uma interioridade cujos cânones deveriam ser problematizados em termos de higienismo. Tais autores, ao analisarem a Escola Nova, conceberam-na como campo em que as práticas higienistas se mantiveram e se sofisticaram durante um longo período na 
história da educação brasileira, criando condições para a penetração do discurso médico na escola.

Maria de Lourdes Spazziani (2001) operou com essa ideia. Segundo ela, os aconselhamentos metodológicos estabelecidos pelos pedagogos escolanovistas foram historicamente ultrapassados por práticas que envergaram a educação brasileira no sentido da medicalização. Entre as propostas da Escola Nova, ao autora incluiu

[...] as técnicas pedagógicas, os recursos e instrumentos materiais, as salasambientes, o ensino individualizado, os trabalhos em grupo, o professor como orientador das atividades educativas; enfim, uma série de modificações que se contrapõem à concepção e às práticas da escola tradicional (p. 52).

Em sua análise, todo esse arsenal procedimental poderia ter sido utilizado para garantir o estímulo ao desenvolvimento dos educandos, mas isso não ocorreu porque o discurso médico teria colonizado as práticas sugeridas pelas ciências sociais.

Dita colonização, segundo Spazziani (2001), teria conduzido as pretensões dos escolanovistas em direção a um modelo pedagógico no qual o saber próprio dos escolares teria sido sobrepujado por conteúdos médicos. Desse modo, referências a higiene, nutrição, crescimento, desenvolvimento, primeiros socorros e doenças teriam tido proeminência nas preocupações dos educadores e, por consequência, escorado simplificações e falsidades acerca das razões para o fracasso escolar.

Danielle Nóbrega (2005) tratou essas supostas simplificações e falsidades em termos de descaminhos trilhados pela ciência médica dedicada à detecção de inadequações dos escolares em relação às ações pedagógicas. A pesquisadora sobrelevou o modo como, historicamente, os escolares cujos gestos eram considerados inadequados foram progressivamente recebendo marcas, estigmas e imposições sociais que quase sempre propugnavam razões biológicas para as dificuldades escolares. Reaparece, nesse momento, a abordagem assimétrica do poder médico sobre a escola, esta apresentada como campo de atuação de um saber médico supostamente hegemônico e determinante.

O processo de sobreposição médica teria, segundo Nóbrega (2005), desviado o olhar pedagógico da subjetividade supostamente inerente a cada qual dos indivíduos, desvio este responsável por sobrepor verdades pseudocientíficas à tentativa do próprio aluno de produzir uma idiossincrática verdade acerca de suas especificidades pessoais.

Também Antunes Diniz (2004) preocupou-se com as relações entre saberes e subjetividades no trato com alunos tidos como inadequados ao convívio escolar. Para tanto, dedicou-se a analisar aquilo que, entre o final do século XIX e o início do XX em Portugal, 
considerava-se ser um conhecimento dirigido aos anormais. Sob esse enquadre, o autor aventou um deslocamento: do enfoque dirigido à fisiologia - próprio do pensamento de Egas Muniz - para as análises de Faria de Vasconcelos, para quem a "organização social pode provocar disfunções no desenvolvimento das crianças” (p. 254).

O dilema entre a precedência da fisiologia ou da sociedade na produção dos desvios escolares foi utilizado por Diniz (2004) para efetivar um apanhado histórico acerca do trabalho realizado por instituições de apoio a surdos e cegos em Portugal durante o momento histórico abordado. Ao investigar o período, o autor destacou uma mudança de paradigma em que o renascimento de uma "Pedagogia Especial a partir do diagnóstico das deficiências" (p. 245) teria permitido que se assumisse "a educação como um acto social, apoiado na psicologia e na sociologia para lhes criar uma maior autonomia individual num mundo real" (p. 261). Garantia-se, desse modo, que os alunos tradicionalmente considerados anormais entrassem "um dia na posse dos seus foros de cidadão" (p. 259).

Entre os objetos de estudo privilegiados pela linhagem investigativa que centra suas atenções na análise acerca da imposição médica, encontra-se o desejo de pesquisar os diferentes tratamentos àqueles alunos que recebiam diagnóstico de uma possível anormalidade. Quase sempre, tais análises localizam preconceitos e estigmatizações em tais diagnósticos.

O tema da educação como ato social foi analisado por Elisabeth Yazlle e Juliana Fernandes (2009). No artigo dedicado a estudar A presença de idéias higienistas $e$ compensatórias na formação de professores para a educação infantil, as autoras constataram - debruçadas sobre a legislação educacional brasileira (LDB de 1996) e confrontando-a com depoimentos de educadores - a manutenção de "concepções preconceituosas sobre crianças, creche, pobreza e famílias" (p. 205).

Yazlle e Fernandes (2009) sugeriram que vigeria um descompasso entre as proposições acadêmicas e as práticas dirigidas à educação infantil, desalinho este verificado na manutenção das "visões assistencialistas, higienistas e compensatórias" (p. 206) apresentadas pelos educadores por elas entrevistados. Tal continuidade seria, segundo as autoras, contraditória em relação ao debate acadêmico, já que "as funções cuidar/educar que, reiteradamente, correspondem nos documentos oficiais e na bibliografia atual sobre a formação de profissionais da educação infantil” (p. 206) não se encontrariam nos discursos dos educadores entrevistados.

Heloísa Rocha (2000) também investigou as práticas higienistas no contexto da Escola Nova. Dedicada a problematizar aquilo que teria configurado a modernização da escola 
brasileira, a autora situou na primeira década do século XX o momento privilegiado para analisar práticas higienistas guarnecidas pela escola àquela época. Partindo da análise de um manual de higiene publicado em 1914 pelo médico higienista brasileiro Afrânio Peixoto, a autora dedicou-se a sondar a respeito das "representações em relação à escola que perpassam as prescrições higiênicas" (p. 57).

Para tanto, Rocha (2000) flagrou os enunciados que estiveram presentes nas discussões em torno da instalação da higiene como uma disciplina escolar durante a gênese do escolanovismo brasileiro. As diferentes acepções acerca de tal disciplina, segundo ela, teriam congregado um conjunto de prescrições que, escoradas em argumentos científicos, definiriam encaminhamentos para minimizar a insalubridade própria da vida urbana. No intuito de prever comportamentos doentios e racionalizar a construção de equipamentos escolares, as práticas higiênicas definidas pelos manuais congregariam, no contexto escolar, aconselhamentos produzidos em diferentes campos discursivos - com destaque para a psicologia e para a medicina - voltados à "correção da natureza imperfeita do homem, tornando legível para o futuro professor o seu lugar na obra de redenção, por meio da inculcação dos hábitos higiênicos na alma infantil’' (p. 71, grifos da autora).

Desse modo, constituindo representações sobre um hipotético presente decadente e um futuro regenerado, os higienistas compilados por Rocha (2000, p. 71) estariam congregando variados campos de saberes para constituírem "uma cultura escolar moderna". Uma cultura cujo cerne fixaria cada um dos escolares na condição de cidadãos em risco diante da periculosidade tanto da vida nas cidades, quanto do atraso civilizacional brasileiro.

A incorporação da perspectiva representacional de análise também se faz presente aí. Desse modo, ao descrever o processo de subjetivação emoldurado pela ciência da higiene, os autores dessa linhagem investigativa findam por atribuir aos procedimentos médicos na escola ações de inculcação e habituação, atribuição própria a apreciações baseadas na assimetria do poder.

A captura do corpo infantil por técnicas preventivas também foi tomada como problema de pesquisa por Ana Cristina Richter e Alexandre Fernandes (2010). A partir de pesquisa etnográfica com professores de crianças de 0 a 5 anos na cidade de Florianópolis, os pesquisadores sugeriram que seria possível utilizar o conceito de vida nua para caracterizar as representações produzidas pelos atores envolvidos no corpus pesquisado. Ditas representações, segundo eles, privilegiariam os caracteres biológicos, notadamente quando elaboradas no interior de práticas de cuidado dirigidas aos infantes. Tal elaboração, por sua vez, justificaria a maneira como até hoje se realiza o trato com a pequena infância: um 
tratamento sempre orientado, como nos apontamentos da Escola Nova, para a preparação fisiológica de indivíduos, capacitando-os, antes de tudo, a viverem em um ambiente que prepararia seus organismos e os predisporia a se comportarem como meros consumidores.

Também tomando os cuidados com a infância como mote, Paula Guimarães (2013) dirigiu suas especulações para a formação de professores em Minas Gerais durante a década de 1920 e analisou o surgimento de instituições auxiliares da escola. Nesse processo, descreveu enunciados dirigidos a instituições como a Associação das Mães de Família, a Caixa Escolar, o Escotismo, a Liga da Bondade e os Pelotões de Saúde; em todos eles, Guimarães (2013) observou o zelo com a formação moral, com a manutenção das crianças carentes na escola, com o incentivo para atividades ao ar livre, com a formação éticopatriótica e com a valorização de hábitos higiênicos. O sentido dessas práticas, segundo ela, seria sempre a proposta de que o Estado irradiasse, a partir da escola, procedimentos normativos para o conjunto da sociedade. Por fim, analisando as referidas ações estatais, Guimarães (2013, p. 163) especulou que seus métodos concebiam o corpo dos infantes como “objeto de manipulação e condicionamento".

O olhar para o trato higienista dirigido à infância, capturando-a ora com intensões mercadológicas ora com pretensões moralizantes, aproxima tal vertente analítica às considerações enquadradas sob o olhar ideológico.

Também José Gonçalves Gondra (2010) observou a centralidade do tema infância ao abordar a constituição do higienismo. Em artigo dedicado a vasculhar a emergência da infância, o autor especulou que tal temática não poderia ser estudada fora das instituições que, desde o século XVIII, passaram a receber aconselhamentos médicos quando se propunham a abrigar os infantes. Ditas práticas institucionais, segundo ele, teriam se mantido na contemporaneidade, levando-o a sugerir que "fomos capturados por essa ordem de saber, por seus jogos de poder, o que faz com que tenhamos em relação a nós mesmos condutas alinhadas às representações fabricadas no interior do campo médico-higiênico" (p. 196).

Desse modo, Gondra (2010) supôs que também a escola teria sido colonizada pelo saber médico desde que os procedimentos educacionais passaram a se escorar em concepções que definiam a infância como etapa temporária da vida. Essa captura discursiva, segundo o autor, sustentaria entendimentos que atribuiriam à vida infantil processos de desenvolvimento e aperfeiçoamento cuja operação desdobrar-se-ia, nos dias de hoje, em evocações relacionadas a princípios de cuidado corporal e conformação moral no ambiente escolar. Portanto, livres dos riscos da acumulação urbana e preservadas das influências retrógradas de suas famílias, as crianças modernas puderam, segundo Gondra (2010), inserir-se em contingentes 
populacionais que, sob o controle do Estado, conduzi-las-iam ao mundo do trabalho, da cidade e da civilização.

Tal concepção da infância como etapa da vida seria central, segundo artigo de António Ferreira (2010), à condução das crianças desde o século XVI, conforme sua leitura de Comenius, em uma narrativa histórica que lhe permitiu localizar, já no século XVIII, a presença da ideia de desenvolvimento infantil nos enunciados da medicina. Desdobrou-se daí, segundo o autor, um "interesse cada vez mais generalizado para com o crescimento da criança" (p. 222), Interesse intrínseco às concepções higienistas em vigor no final do século XIX.

Destarte, asseverou Ferreira (2010) que, associando o esperado crescimento físico com o desejado desenvolvimento geral das crianças, pôde a medicina sugerir práticas educacionais escoradas em saberes que reivindicavam cientificidade, pois se amparavam em critérios objetivos. O cume da cientificidade educacional teria sido alcançado quando da emergência da pedologia. A ciência, vigente em Portugal desde a primeira década do século XX, teria atrelado definitivamente os métodos da psicologia e da sociologia aos da botânica. Tal anexação permitiria, segundo o autor, que na infância pudessem ser visualizadas as qualidades adultas em germe e que, por conseguinte, fosse possível corrigir as vicissitudes de desenvolvimento a partir de determinados cânones antropométricos.

Na mesma direção se destaca um artigo assinado em conjunto por António Ferreira e José Gonçalves Gondra (2006). No estudo - que incluiu teses apresentadas à Faculdade de Medicina do Rio de Janeiro no século XIX -, os autores ratificaram que a concepção etapista da infância, além de relacionar-se diretamente com o discurso médico, permitiu que esse discurso espraiasse sua racionalidade para diversos campos do convívio social.

A racionalização médica dirigida ao trato com os infantes, de acordo com Ferreira e Gondra (2006, p. 129), operou com o princípio segundo o qual o tempo da natureza deveria ser respeitado quando se pretendesse garantir a "entrada da criança na cena social". Essa concepção que associava a infância a um período de aprendizado e maturação se manteria até a atualidade e seria responsável por uma "representação dominante e universalizante de infância" (p. 131), cujos discursos perpetuadores "refletem modelos institucionalizados delineados em função de interesses e poderes dominantes” (p. 132).

Esses mesmos poderes, conforme artigo assinado por Heloísa Rocha e José Gonçalves Gondra (2002), seriam profundamente marcados pela ascendência do saber médico na sociedade brasileira desde pelo menos meados do século XIX. O mecanismo de saber/poder, asseveraram os autores, teria sido responsável pela "produção de uma nova espacialidade e de 
uma nova temporalidade, subjacente à qual, está a concepção de um corpo moldável e do poder do meio externo nessa obra de modelação" (p. 508).

A perspectiva modeladora atribuída às definições médicas dirigidas ao convívio escolar foi mantida por Heloísa Rocha (2011) quando, em artigo dedicado a analisar manuais escolares de higiene produzidos para a escola primária brasileira na década de 1920, atentou para o

[...] projeto da educação higiênica, por meio da qual se buscou incutir nas crianças, desde a mais tenra idade, um conjunto de hábitos capazes de, a um só tempo, redimir o povo da suposta ignorância, anomia, doença e libertar o país da pecha que o identificava a um 'enorme hospital' (p. 153).

Tal visualização pessimista dirigida à nação, de acordo com a autora, foi acompanhada de uma profunda esperança, difundida pelos discursos sanitaristas, de que a regeneração nacional seria efetivada quando se expandisse a escolarização das crianças. Dando sequência ao raciocínio, Rocha (2011) sugeriu que, nos referidos discursos, o analfabetismo representaria a origem de todos os males da população brasileira, tanto os morais quanto os físicos. Assim, o entrelace entre alfabetização, segurança nacional e regeneração racial teria deslindado imagens que "podem ser lidas como dispositivos políticos e pedagógicos de disciplinação" (p. 153).

O projeto disciplinar contido nas propostas higienistas foi ainda tema para outro artigo de Heloísa Rocha (2010), este confeccionado a fim de dissertar sobre a agenda internacional voltada à promoção da higiene. O texto foi produzido a partir de documentos registrados no II Congresso de Higiene Escolar e Pedagogia Fisiológica, realizado em Paris, no ano de 1905.

Destacou a autora que, naquela oportunidade, a preocupação geral dos conferencistas repousou em franca guerra contra os ditos maus hábitos dos infantes, cuja manutenção levaria à perda de vigor físico e à intensificação das anormalidades. Em tal contexto, os procedimentos higienistas priorizavam a produção - criteriosa, detalhada, profundamente debatida - de uma caderneta em que seriam registrados dados acerca da fisiologia, da saúde e das capacidades cognitivas dos escolares. De posse desses dados, os sanitaristas teriam intentado "apresentar como legítima e necessária a intervenção dos médicos sobre a instituição escolar e as crianças" (ROCHA, 2010, p. 237). Por extensão, os professores, conhecedores dos princípios da higiene - "considerada um domínio específico da medicina" (p. 245) -, acompanhariam nos corpos de seus alunos a evolução dos critérios registrados nas cadernetas e procederiam a uma vigilância diuturna sobre a saúde dos educandos. 
Heloísa Rocha, José Gondra e António Ferreira, ao tomarem a infância como objeto de pesquisa, encontram-na no centro da tecnologia médica e analisam os efeitos dessa tecnologia em termos de disciplinação, moralização, modelização e vigilância. Todos esses enfoques foram caros aos escritos de Foucault na época em que o pensador ainda se dedicava a analisar o discurso médico em termos do binômio saber-poder.

Também Vera Regina Marques e Fabiana Farias (2010) voltaram suas análises para o artifício de vigilância estabelecido nos procedimentos desdobrados pelos higienistas. Pesquisando em documentos oficiais produzidos pela Inspetoria Geral de Ensino do Paraná na década de 1920, as autoras atribuíram aos exames médico-escolares realizados em mais de 5.308 alunos no período estudado práticas próximas ao que elas nomearam, à luz do pensamento foucaultiano, de polícia médica.

Tais práticas, segundo Marques e Farias (2010, p. 291), responsabilizavam os professores por zelarem pela articulação entre vigor físico e moralização, uma vez que dessa comunhão vicejaria, consoante as conclamações de tal "cruzada higienizadora", indivíduos "úteis ao estado e à nação". A conexão entre critérios comportamentais e fisiológicos estaria diretamente relacionada às concepções eugenistas que frutificaram no período histórico por elas estudado. As autoras então sustentaram seu argumento por meio da análise sobre o trato discriminatório que os referidos documentos dirigiriam aos elementos rurais presentes tanto na conduta, quanto no aspecto biológico dos indivíduos examinados.

A higiene como estratégia de segregação social foi tema de artigo assinado por Valter Martins (2003). Investigando textos jornalísticos produzidos em Campinas ao final do século XIX, o autor compilou indícios para sugerir que se empreenderia à época analisada um amplo projeto de aburguesamento que tomaria a cidade, ao mesmo tempo, como alvo e como modelo. Para tanto, Valter Martins (2003) - declarando-se afastado das teorizações foucaultianas que atrelariam, segundo ele, controle social e higiene - abordou um conjunto de posturas que propunham criar "uma cidade educada, limpa e saudável” (p. 81). Focalizou sua leitura nas ações policiais como atitudes inseridas em uma suposta "pedagogia do cassetete" (p. 83), por meio da qual se teria empreendido uma "higienização social" (p. 84) baseada na marginalização de determinados elementos urbanos, tais como negros, cafetões e operários.

É interessante observar que tanto os autores que se utilizam da teorização foucaultiana quanto aqueles que a dispensam convergem quando discorrem a respeito das ações assimétricas do poder médico sobre a educação, no caso, ações que são enunciadas como higienização, policiamento e modelização. 
Os discursos segregacionistas escorados em saberes biológico-médicos também serviram de tema aos pesquisadores que se dedicaram a estudar práticas eugênicas no contexto da Escola Nova brasileira. Entre tais artigos, destacamos o de André Silva (2012), debruçado sobre os Imperativos de beleza presentes na cultura brasileira desde o início do século XX. O autor compilou, nas obras de Renato Kehl - eugenista presente no movimento escolanovista brasileiro -, conexões com aquilo que no presente foi por ele denominado cultura fitness.

Tais conexões serviram para que Silva (2012, p. 213) ponderasse acerca de como o ideal regenerativo atribuído à educação física de matriz eugênica contribuiu para "ordenar e classificar os corpos, ao eleger determinadas formas e execrar tantas outras”. A referida discriminação teria produzido uma representação a partir da qual efetivou-se "uma beleza totalitária, discriminatória e preconceituosa e [que], com isso, desumaniza todos os outros corpos" (p. 219).

Diferentemente da segregação violenta visualizada pelas análises de Valter Martins (2003), André Silva (2012) sugeriu que a discriminação dos corpos tidos como inferiores operaria por meio de mecanismos de padronização. Desse modo, não apenas as classes subalternas seriam alvo da exclusão biológica. Muito além da coerção física, a imposição eugênica teria sido aplicada em termos de modelização de gestos e critérios de convívio para o conjunto da sociedade.

Enunciados higiênicos formulando modelos de corpos a serem decalcados em escolares foi tema para um considerável grupo de artigos. Entre eles, destaca-se um texto assinado por Pablo Scharagrodsky. Dedicado a pesquisar as mudanças ocorridas no ensino de educação física na Argentina durante a passagem do século XIX para o XX, o autor centralizou suas análises na obra de Romero Brest, este então anunciado como pai da educação física argentina.

A maior contribuição de Brest, segundo Scharagrodsky (2004, p. 86) teria sido a inserção de uma "fundamentación fisiológica" em seus projetos de reforma do ensino de educação física. Ao fazê-lo, acreditava o educador que perderiam força os antigos métodos cujo cerne consistia, segundo ele, em exercícios militares.

Ademais, o objeto central das preocupações de Scharagrodsky (2004, p. 90) concentrou-se nos efeitos das propostas de Brest, cujas ideias teriam sido incorporadas por "mandatos morales que excediam la propria biologia". Essa suposta distorção, segundo o pesquisador, teria feito os aconselhamentos do educador vergarem em direção a essencializações cujos desdobramentos redundariam na fixação do masculino/feminino como 
modelo para distinção das práticas educacionais e, por conseguinte, para "uma práctica social y política del control de cuerpos" (p. 104).

Na linha de Scharagrodsky (2004), Inés Dussel (2005) investigou as regulamentações produzidas em torno do uso de uniformes na Argentina durante a passagem do século XIX para o XX. Em sua análise, ela sugeriu haver em tais representações uma "política de regulación de los cuerpos", chamando a atenção para a configuração de uma suposta "estética de la lavabilidad" (p. 67). Daí ela ter sugerido que, no interior do discurso higienista, combinar-se-iam práticas a fim de formar indivíduos que valorizassem a pureza racial e moral como ações de civilidade.

Ademais, segundo a autora, a estética higienista incluiria uma compreensão da fisiologia humana em termos de mecanização. A partir dessa visualização, os professores seriam convocados a "maximizar las capacidades del cuerpo, entendido ya no como um organismo cuasi mecânico sino como um conjunto de músculos y órganos que debe desarrolarse por el ejercicio sistemático" (p. 76).

Tais estetização, mecanização e, por conseguinte, modelização mantiveram-se como tema em diferentes artigos compilados. No caso do texto assinado por Lucia Moctezuma (2011) as fontes foram livros de leitura para a educação primária, materiais chancelados por sucessivos congressos de higiene (entre 1882 e 1940) e repletos de "representaciones sobre el cuerpo infantil en la escuela primaria mexicana" (p. 36).

A produção de representações que se ofereceriam como modelos - tanto de conduta quanto de saúde - aos corpos dos infantes foi ainda mote do artigo de Moisés Kuhlmann Junior e Maria das Graças Magalhães (2010), que se debruçaram sobre 155 exemplares de almanaques produzidos pela indústria farmacêutica, tanto brasileira quanto estrangeira, nos anos de 1911 a 1953. No interior de tais registros, os autores flagraram um estreito vínculo entre discursos egressos dos debates imersos no sanitarismo e evocações dirigidas ao nacionalismo e à modernização do país. Desse modo, sugeriram que a infância teria se tornado alvo em um suposto "processo de normalização da sociedade moderna” (p. 328).

Ainda no que concerne à centralidade da infância na implantação de um projeto civilizatório liderado pelos higienistas, é preciso mencionar o texto de Adrián Ascolani (2010). O autor argentino empreendeu uma compilação de livros de leitura adotados pelos sistemas estatais argentinos de 1884 até 1946 e afirmou que, independentemente do momento histórico, a maioria dos enunciados demonstrava preocupações quanto à socialização, à disciplina, à urbanidade, à segurança, à saúde pública e ao patriotismo, entre outras. No entanto, Ascolani (2010) ressaltou uma caraterística que teria se tornado hegemônica na fase 
escolanovista e amparado práticas posteriores. Tratar-se-ia da "moderación de las conductas como capacidade de autorregulaciòn infantil”" (p. 311).

A preocupação com o autocontrole, analisada como contribuição do escolanovismo, foi assunto central também no artigo de Greiciele Bassinello (2004). A autora constituiu uma empiria formada por trechos dos Parâmetros Curriculares Nacionais publicados no Brasil em 1997 e os comparou a alocuções presentes em um manual de higiene assinado por Afrânio Peixoto nos anos 1930.

Bassinello (2004) chegou a conclusões parecidas com aquelas aventadas por Adrián Ascolani (2010). A autora brasileira observou que, embora desde o século XIX a questão da saúde tenha estado presente no ambiente escolar, nos tempos escolanovistas, a lógica contida no dilema "ensinar saúde ou ensinar para a saúde" (p. 39) teria deslocado a condução dos escolares do primeiro para o segundo termo da expressão. Assim, desde as reformas implantadas pela Escola Nova, cada estudante teria sido convidado a refletir sobre suas relações com seu próprio corpo e com seus próprios comportamentos. Bassinello (2004, p. 41) sustentou a tese da permanência desse movimento reflexivo quando sugeriu a conexão entre identidade e cuidados com o corpo, própria das evocações contidas nos PCN em relação a questões como "nutrição, valorização dos vínculos afetivos e a negociação de comportamentos apropriados para o convívio social” (p. 41).

Nessa linhagem discursiva, as visualizações dos pesquisadores encontraram nos procedimentos higienistas práticas circunstanciadas em termos de colonizações, racionalizações, simplificações, descaminhos, estigmas, disfunções, incorreções científicas, capturas, fabricação de representações, universalizações, policiamentos, discriminações, ordenamentos, modelizações, essencializações, enfim, ações que inexoravelmente envolviam imposições e falsificações em nome da constituição de seres dóceis e úteis.

Os autores dessa última linhagem pareceram-nos menos otimistas que os três grupos antes apresentados. Eles analisaram a Escola Nova sobrelevando suas práticas medicalizantes e entendendo as convocações dos sanitaristas, dos educadores e dos burocratas nos tempos escolanovistas como representações higienistas.

Sob a alcunha do higienismo, tais pensadores da representação encontraram no projeto da Escola Nova práticas orientadas para modificar condutas por meio de ações dirigidas à contenção dos indivíduos. Tal como as demais linhagens investigativas, nesse campo, a participação dos educandos em processo de disciplinamento se restringia à adesão e à obediência a discursos impositivos. 
Evocando preponderantemente teorizações foucaultianas, essa última vertente analítica, apesar de modificar os objetos de estudo, novamente dirigiu o foco de suas análises para o suposto caráter assimétrico do poder. Destarte, fosse para eliminar a exploração capitalista, para salvar o planeta, para garantir justiça nas relações pessoais ou para enfrentar poderes, na quase totalidade dos artigos lidos encontramos algum tipo de relação entre educação e salvação/modificação/autonomização.

Conforme os contraideólogos, salvar seria sinônimo de conscientizar/refletir autonomamente; segundo os clínicos, seria o mesmo que curar/modificar hábitos; para os democratas, seria algo análogo a potencializar as individualidades por meio da autorreflexão; por fim, os representacionistas associariam o ato da salvação ao desvelamento das ilusões do poder.

Em todas essas abordagens, os poderes apoiados nos discursos que justificam práticas impositivas são apresentados como ações assimétricas sobre corpos submissos que sofrem, quase passivamente, a sobreposição dos assujeitamentos.

Dedicados a ultrapassar a hipótese da imposição assimétrica supostamente presente em saberes dirigidos à vida e à saúde na contemporaneidade, rumamos em direção a um tema bastante abordado: a alegada medicalização da escola e da sociedade.

Procurando auscultar perspectivas diversas, diversificamos o campo de análise, deslocando-a dos enunciados acadêmicos para aqueles marcados pela militância. Para tanto, compilamos enunciados presentes nas memórias do II Seminário Internacional Educação Medicalizada, realizado em São Paulo no ano de 2011. O evento, organizado com o objetivo político de criticar frontalmente a presença do discurso médico na escola, foi promovido pelo Fórum Sobre Medicalização da Educação e da Sociedade, instância criada em 2010 e que hoje congrega centenas de instituições - de sindicatos a escolas, de políticos a associações de psicologia e órgãos governamentais - dedicadas a atuar como grupo de pressão contra o Estado e as corporações ligadas à indústria farmacêutica, quando esses setores extrapolam suas funções relacionadas à salubridade e ao manejo dos contingentes populacionais.

Nos relatos dessas conferências, encontramos problematizações acerca das relações entre escola e medicina que muito acrescentaram para movimentar nossa premissa de pesquisa. De acordo com tal campo discursivo, a alegada explosão de diagnósticos em torno dos chamados transtornos escolares estaria ligada, sobretudo, à inexatidão científica gerada 
por preconceitos e interesses econômicos presentes em enunciados proferidos, mormente, por uma psiquiatria propensa a manter a preponderância cultural da classe dominante (COLLARES, 1995; MACHADO, 1996; PATTO, 1984, 1999). Nesse sentido, viveríamos hoje a era dos transtornos (COLLARES; MOYSÉS; RIBEIRO, 2013), no interior da qual a redução da individualidade à ação de células e órgãos desembocaria naquilo que tem sido designado como biologização da vida, donde "medicalização e reducionismo estão inscritos no paradigma positivista de medicina" (p. 16).

A biologização da vida, conforme estabelecem as supracitadas autoras, faria parte de uma ação política cujo objetivo levaria ao escamoteamento das verdadeiras causas da inapetência dos escolares. Essas causas, segundo tal perspectiva, não deveriam ser procuradas em teorias gerais que tenderiam a naturalizar ou somatizar idiossincrasias individuais. Antes, as causas do fracasso escolar repousariam em intercorrências ou acidentes gerados no processo social de construção da personalidade dos discentes.

Inês Barbosa de Oliveira (2013) faz coro com a tese da perpetuação do legado positivista, aventando que tal cientificidade, no presente, estaria operando "uma guerra contra tudo que foge do previsto, esperado, normatizado, normalizado" (p. 84). A decorrência desse embate, segundo a autora, estaria visível no evidente descompromisso de pais e professores diante das diferenças apresentadas por seus educandos. A transformação do trabalho pedagógico em algo prazeroso e interessante, portanto, viria sendo preterida em favor da busca por insuficiências biológicas e, consequentemente, por uma atuação pedagógica submissa ao tratamento remedial das dificuldades.

Dita tendência, ao focalizar uma suposta subserviência da pedagogia à farmacêutica, foi tratada em termos de um obscurantismo reinventado (MOYSÉS; COLLARES, 2013). Com efeito, Maria Aparecida Moysés e Cecília Collares alegaram que as queixas escolares deveriam ser tratadas como questões sociais. Vale salientar, entretanto, que as práticas chamadas por elas de medicalizantes, tal como no supostamente obscuro passado positivista, estariam apoiadas em teorias que associavam a sociedade a um organismo vivo, suscetível à intervenção científica e regeneradora. Justificar-se-iam dessa maneira, conforme as autoras, posturas pseudocientíficas diante de problemas sociais e escolares, levando à hegemonia de procedimentos educacionais padronizados e massivos.

O modo positivista de tratar a educação e as dificuldades escolares estaria também presente, segundo Felipe Oliveira e Marilene Proença de Souza (2013), nos textos de grande parte dos projetos de lei dedicados a garantir os direitos dos portadores de transtornos escolares. Tal orientação jurídica, nessa perspectiva, "faz com que os professores não mais 
enxerguem as crianças como seres humanos em desenvolvimento e, portanto, passíveis de aprendizagem, e sim passem a ver as crianças como saudáveis ou doentes” (p. 218). Seria possível acrescentar a essa abordagem - considerada ultrapassada - a atuação de instituições norte-americanas que veiculariam discursos tendenciosos produzidos em órgãos como a Associação de Psiquiatria Americana (APA) ${ }^{9}$ (IRIART; IGLESIAS-RIOS, 2013).

Ademais, segundo Celia Iriart e Lisbeth Iglesias-Rios (2013), para além do anacronismo, o acosso médico seria agravado por sua suposta inconsistência científica. Destarte, um transtorno como

[...] o TDAH é diagnosticado com base em observações do comportamento das crianças, uma vez que não existem provas definidas como objetivas (marcadores biológicos, provas neuropsicológicas ou genéticas, ou estudos de neuroimagens) capazes de detectar os supostos desequilíbrios bioquímicos (p. 27, tradução nossa).

Iriart e Iglesias-Rios (2013) sustentam a tese de que haveria um amplo processo de "governamentalidade biomédica" (p. 36, tradução nossa) operando na definição do transtorno do déficit de atenção. Em consequência disso, a alegada precariedade dos diagnósticos insuflaria poderes dedicados a garantir "a internalização do controle e a regulação dos corpos" (p. 36, tradução nossa). Na visão das autoras - tributária de uma leitura foucaultiana -, portanto, o poder médico norte-americano abdicaria do rigor científico em nome da regulação e do controle.

A tese da manipulação e da consequente inconsistência científica é complementada por José Gomes Temporão (2013), por meio da denúncia de que a postura medicalizante de profissionais da saúde os tornaria reféns do "complexo econômico-industrial da saúde" (p. 70). Segundo essa abordagem, a pressão pela eficiência dos gastos estatais combinar-se-ia a uma formação cada vez mais precária dos novos médicos, constituindo "uma consciência alienada de prescritores e pacientes" (p. 72). Tal alheamento explicaria o uso crescente de psicofármacos, transformando os pacientes em meros consumidores e seus médicos em alienados.

O marketing das indústrias farmacêuticas, tal como propôs Leon Benasayag (2013), alavancaria a dita alienação. Segundo o autor, o principal efeito da mercantilização dos fármacos seria o desvio na tradicional condição dos medicamentos: o remédio, antes um bem

\footnotetext{
${ }^{9}$ A APA é responsável pelo DSM e desde 1952 publica atualizações de sua classificação das doenças mentais. A versão mais recente é o DSM-V, de 2013. Disponível em: 〈http://www.psychiatry.org/DSM5>. Acesso em: 15 dez. 2014.
} 
social, teria passado à condição de mercadoria. Assim, as estratégias de promoção desse bem econômico seriam as mesmas aplicadas a qualquer outra mercadoria.

Entre as ações do marketing farmacêutico, Benasayag (2013) elencou: a distração, por meio da qual se desviaria o olhar do cliente para a efetiva condição da mercadoria (por exemplo, associando o antidepressivo Zoloft ${ }^{10}$ à imagem de felicidade); a criação de problemas para oferecer soluções; a apresentação gradual dos benefícios da mercadoria; o uso da mensagem publicitária como ensinamento sobre o produto; o tratamento do público como criança; o desvio da reflexão para a emoção; o estímulo para que o público concorde com a mediocridade; o reforço à autoculpabilização, demonstrando os riscos em dispensar o medicamento; o envolvimento de médicos e pesquisadores na divulgação dos remédios; a criação, por fim, de “enfermidades inventadas" (BENASAYAG, 2013, p. 165, tradução nossa).

Pari passu à mercantilização, Leon Benasayag apontou para o vínculo inexorável entre a ação dos psicoativos e a definição dos transtornos. Segundo essas definições, tal medicina em estado de alienação definiria, por exemplo, o Transtorno do Déficit de Atenção com Hiperatividade (TDAH) como um transtorno tratável com Ritalina. ${ }^{11}$ Isso demonstraria, conforme assevera o autor, um íntimo relacionamento entre os experimentos das indústrias farmacêuticas, as definições do Manual Diagnóstico e Estatístico de Transtornos Mentais (Diagnostic and Statistical Manual of Mental Disorders - DSM) e os critérios estabelecidos pela agência estadunidense Food and Drug Administration (FDA), responsável por analisar e permitir o lançamento de medicamentos em seu mercado.

A descrição dessas práticas interesseiras levou Silvia Faraone e Eugenia Bianchi (2013) a sublinhar a emergência de novos processos de subjetivação na contemporaneidade. De acordo com tal perspectiva, a medicina atual dirigir-se-ia muito mais a definir modos de viver do que, propriamente, perspectivas de cura.

No que tange aos novos estilos de vida em voga na contemporaneidade, Luciana Calliman (2013) apontou a ascensão de tecnologias subjetivas baseadas no exercício de uma hipotética cidadania biológica. Esta, na acepção da autora, estaria centrada na ideia de que hoje os indivíduos organizariam suas individualidades cada vez mais a partir de biodiagnósticos. Tais procedimentos vasculhariam nos corpos examinados marcadores para determinadas doenças. Assim, munidos de seus diagnósticos, os cidadãos biológicos

\footnotetext{
${ }^{10}$ Nome comercial do cloridrato de sertralina, patenteado pela Pfizer.

${ }^{11}$ Nome comercial do cloridrato de metilfenidato patenteado pela Novartis.
} 
encontrariam as explicações somáticas para seus próprios comportamentos e, por conseguinte, exigiriam seus direitos perante o Estado. A autora destaca, ainda, a potência política desse tipo de consciência de si, pois, portando um diagnóstico, o cidadão passaria a justificar suas limitações como elementos de sua natureza biológica e reivindicaria sua aceitação pública a partir da condição definida pelo transtorno. Tal atitude tornar-se-ia parte da própria história do diagnosticado, que deveria formar fileira na "luta por uma vida mais plural e diversa" (CALLIMAN, 2013, p. 118).

Em nossa leitura, o conjunto de críticas à medicalização da sociedade, mesmo quando se contrapõe à suposta manipulação interesseira operada por determinadas práticas científicas, preservaria a crença no viés redentor da ciência. Nota-se que tais críticas parecem cultivar a crença em uma medicina outra, mais criteriosa, mais tecnológica, mais livre da intromissão do grande capital, mais desprovida de interesses estatais e, portanto, menos submetida aos ditames econômicos. Uma medicina na qual o marketing não mais controlaria a produção e a venda de remédios, permitindo aos pacientes, em última instância, a livre expressão de sua subjetividade e de sua cidadania.

As referidas críticas assemelham-se deveras às sobreditas análises acerca da Escola Nova. No interior desses sítios argumentativos, seríamos levados a considerar que os processos de subjetivação escolar foram provocados ora por uma pedagogia insuficiente ora por uma medicina sobredeterminante.

Conforme aventamos, compreender os meandros da relação entre o discurso médico e os atuais processos de subjetivação obrigar-nos-ia a aprofundar sobremaneira o tipo de análise em voga. Em nossas conjecturas, o que estaria em jogo no encontro entre enunciados médicos e pedagógicos extrapolaria sobejamente questões de cunho epistemológico, econômico, político e/ou ideológico. Todas essas questões, sem dúvida, estariam presentes no processo de medicalização da sociedade; entretanto, considerando o poderoso caráter performativo do discurso médico, destacamos algo fundamental em suas estratégias: a composição de visualizações em que o corpo individual torna-se efeito do entrechoque de discursos que, inexoravelmente, escoram narrativas de si nas quais a organicidade biológica, a interioridade psíquica e o posicionamento social amalgamam-se como expressão de idiossincrasias livres e ativamente constituídas.

Ensejando ora longevidade, ora aprimoramento das habilidades, ora equilíbrio, vigor, rendimento e eficiência, entre outras condutas, as subjetividades que se apresentam sob os cânones de visualização de corpos inseridos na perspectiva médico-escolar desejam e são instigadas a desejar comportamentos, tratamentos, dietas e exercícios coerentes com os signos 
recomendados pelos especialistas da vida biológica. Tal captura do corpo pelas narrativas psicobiológicas, supomos, garantiu historicamente a pretensão profilática tanto de médicos quanto de educadores.

Aproximemo-nos ainda mais daquilo a que denominamos visualização de corpos contemporâneos, compreendendo seus meandros. Nesse percurso, mantenhamos a problematização acerca do papel desempenhado pelos procedimentos da Escola Nova no que tange à incorporação dessa visualização aos processos de subjetivação contemporânea. 


\section{Preparo das lentes: foco neurocientífico}

\section{Conheçamos Joseph Paul Jernigan.}

Texano, nascido em 1954 e falecido em 1993. Em 1981, foi condenado à morte por assassinar a sangue frio um senhor de 75 anos. Após 12 anos no corredor da morte, Jernigan teve negado seu último pedido de clemência. Seria executado em cadeira elétrica, não fosse uma sugestão apresentada pelo capelão que há tempos o acompanhava. Caso o condenado aceitasse oferecer seu corpo ao Visible Human Project, ${ }^{12}$ ele teria sua pena comutada: de execução na cadeira elétrica para injeção letal.

O réu aceitou. Em 1994, imediatamente após a pena capital, seu cadáver foi congelado em gel a $70^{\circ} \mathrm{C}$ negativos e submetido a 1.871 cortes transversais que o dividiram em fatias de 1 a 0,3 milímetros. Cada uma dessas partes foi digitalmente fotografada e reunida às demais por meio de filmagem. Hoje, as várias seções desse corpo visível estão separadamente arquivadas, compondo uma complexa taxinomia dos tecidos que constituem o experimento biológico.

Assim, após executado, Jernigan ressuscitou como um atlas anatômico produzido e exposto pela National Library of Medicine de Washington, sob a direção de Michael J. Ackerman. Em todo o mundo, diferentes instituições aderiram ao Visible Human Project, garantindo ao homem visível ações como o movimento dos fluxos sanguíneo e respiratório. São mais de 30 gigabites de dados disponíveis na web para usos diversos: estudos de anatomia; treinamento de cirurgiões; referência para diagnósticos; planejamento de tratamentos e modelização de traumas; desenho de próteses; referência para crescimento e desenvolvimento normais; dados de pesquisa para medicina forense; simulação de doenças, de traumas e de ação dos medicamentos, entre outros.

Considerando as atuais tecnologias biomédicas, a digitalização como prática de imageamento do corpo é algo bastante complexo e que envolve um intenso desenvolvimento computacional, além de profundos avanços nos campos da matemática, da química e da física. Regula Burri e Joseph Dumit (2007), socióloga e antropólogo estadunidenses dedicados a estudar as relações entre a biotecnologia e seus usos, apoiaram suas reflexões nas etapas envolvidas na produção de imagens de ressonância magnética. ${ }^{13}$ Os autores afirmaram que a

\footnotetext{
${ }^{12}$ Disponível em: <http://www.nlm.nih.gov/research/visible>. Acesso em: 21 out. 2013.

${ }^{13}$ Técnica de imageamento em que se submete o examinado a um forte campo magnético e se mapeia a condição dos tecidos atravessados pelo magnetismo por meio do registro das graduações de energia absorvida por eles no momento em que seções do corpo são atravessadas pelo referido campo magnético.
} 
produção de figuras realizada pelo aparelho de ressonância transitaria por um intricado percurso: desde a escolha das áreas a serem visualizadas, passando pelo estabelecimento da escala e da resolução das colorações, até chegar ao ângulo, à perspectiva e à rotação da imagem final. Todo esse processo seria perpassado por parâmetros, análises estatísticas e dados que somente poderiam ser estabelecidos pela visual expertise a eles vinculada.

Burri e Dumit (2007) desdobram o imageamento por ressonância magnética em três momentos: a produção, o compromisso e o desenvolvimento. No campo da produção, destacam os cálculos envolvidos para a elaboração dos registros. A fim de operá-los, produzir-se-iam modelos matemáticos que, como todos, somente podem incluir dados passíveis de medição. Dessa maneira, ficaria a cargo dos elaboradores de softwares a inclusão ou exclusão de valores que permitiriam a transformação das imagens capturadas em uma visualização compreensível por médicos e pacientes. Acerca dessa etapa, os autores consideram importante ressaltar que, diferentemente dos antigos técnicos que empregavam raios X - cuja expertise limitava-se à operação do aparelho -, os atuais aplicadores dessas sofisticadas técnicas de imageamento do corpo deveriam ser, necessariamente, conhecedores das patologias.

No que tange ao compromisso, Burri e Dumit (2007) ponderaram sobre a relação entre a visualização e os conhecimentos científicos disponíveis. Para tanto, analisaram como as visual expertises não somente eliminam dados cuja medição seria impossível, mas também medidas consideradas incomparáveis. Desse modo, manter-se-iam apenas imagens que estabelecessem informações significativas, ou seja, que evidenciassem anormalidades diante dos dados arrolados e convencionados pela comunidade científica.

Quanto ao desenvolvimento, Burri e Dumit (2007) afirmaram que seria impossível a produção de imageamento corporal sem a participação definitiva dos especialistas. Estes apenas produziriam suas visualizações a partir de modelos, de modo que sua atuação operaria rumo à criação de imagens progressivamente individualizadas.

No caso da modelização, os autores destacaram a preocupação dos especialistas em superar permanentemente as lacunas dos modelos, as obstruções, as mutações da clínica e, enfim, as limitações, sempre confiando que a progressão evolutiva dos conhecimentos científicos levaria a uma plena visualização dos corpos imageados.

Catherine Waldby (1997), socióloga vinculada à Universidade de Sydney, dedicou-se a analisar o Visible Human Project por meio de uma perspectiva semelhante à adotada por Burri e Dumit. Para ela, a convergência entre corpos e computadores "não é somente conceitual, é também material, envolvendo de forma literal a reorganização da carne” (p. 228, 
tradução nossa). Tal reorganização, segundo a autora, poderia ser observada nos novos caminhos trilhados pelo ensino de medicina; em cirurgias a laser onde o computador oferece as coordenadas; nas trocas de dados entre médicos via web; em pesquisas médicas nas quais os modelos matemáticos apresentam-se como objetos experimentais; na criação de bancos de dados genéticos etc.

Nesses casos, também a matematização viabilizaria um complexo intercâmbio de dados a partir do qual o organismo humano seria integrado a um sistema de informações que garantiria a permanente programação da anatomia e, por conseguinte, sua constante reprogramação. Assim, mais do que uma ferramenta de projeção, o uso do computador forjaria uma "filosofia cibernética" (WALDBY, 1997, p. 230, tradução nossa) que permitiria ao discurso médico estabelecer transformações em campos sociais muito além daqueles atinentes à saúde ou à doença. Tais campos beneficiar-se-iam da modelização matemática do funcionamento corporal, na medida em que ela enquadraria esses corpos em usos considerados valiosos para locais específicos de produção.

Esse aspecto formaria a base sobre a qual caracterizamos a abordagem de nossa investigação. As práticas biocientíficas foram aqui usadas como mirante para que focalizássemos aquilo que pretendíamos criticar no presente: a ação da expertise das ciências biopsicopedagógicas quando da constituição de processos de subjetivação de escolares que narram a si mesmos como entes propensos à medicalização. Para tanto, vasculhamos agora a produção de subjetividades nas práticas contemporâneas de visualização de corpos, partindo das contribuições de Nikolas Rose.

O pensador inglês levou a cabo uma extensa pesquisa sobre as relações entre biociência e processos contemporâneos de subjetivação. Nesse campo, dedicou-se a arrolar práticas que, na atualidade, estabeleceram o corpo humano como locus de uma sofisticada operação identitária, cujo cerne seria o processo de contínuo aprimoramento da vida presente nesse corpo.

Em A política da própria vida, Rose (2013) discorreu sobre a maneira como nós, humanos modernos, conduzimo-nos, explicamo-nos e identificamo-nos por meio da condição de seres constituídos biologicamente. Segundo ele, as coevas estratégias para explicação da vida alcançaram níveis bastante profundos, oferecendo possibilidades de manipulação, desenvolvimento e aperfeiçoamento que - para além da mera alienação ideológica, ou mesmo da captura pela normalização disciplinar - suscitaram a reformulação das bases em que até então se assentou a corporeidade humana. 
Como elementos-chave de suas análises, Nikolas Rose (2013) destacou os movimentos de molecularização, otimização, subjetivação, expertise e bioeconomia. Tais movimentos, entre outros, formulariam aquilo que o autor denominou biopolítica molecular.

Três elementos foram aventados por Rose (2013) para delinear o que ele intitulou molecularização da vida. Primeiramente, ele assevera que a "criação de novas formas de vida molecular" (p. 27) teria transformado o interior dos laboratórios em fábricas para criação de novas estruturas moleculares. Esse trabalho fabril superaria a preocupação com o fenótipo, própria dos tempos em que a genética ainda se centrava na hereditariedade. Ou seja, nessa perspectiva, as atuais pesquisas acerca da genética humana tomaram o interior da corporeidade como estruturas programadas por moléculas cujas ações seriam detectáveis e, por conseguinte, programáveis em ambiente sintético, ou seja, laboratorial e extracorpóreo.

Além disso, as atuais intervenções moleculares visariam atingir o organismo em funcionamento. Esse é o caso da interferência medicamentosa em neurotransmissores. Ademais, dita molecularização da vida estaria profundamente apoiada na simulação cibernética, na medida em que estabeleceria o ambiente virtual como campo para infinitas simulações, sempre baseadas na modelização matemática. O espaço laboratorial da sintetização agregar-se-ia ao espaço virtual da simulação para garantir uma visualização, o mais precisa possível, de um funcionamento tido como estrutural e genérico, porque químico e não corpóreo.

Por meio do termo otimização, Rose (2013) designou práticas que evidenciariam uma crescente preocupação dos biólogos, engenheiros, peritos em informática e matemáticos no sentido de compreender o "processo vital dos corpos e da mente" (p. 32). A busca pela determinação das sequências de DNA, que produziriam as diferentes proteínas participantes na constituição de estruturas corpóreas, apresentou-se como importante meta desse processo. Muito além da cura, as técnicas de otimização ultrapassariam aquilo que antigamente ligava o tratamento à correção. A novidade gerada por elas deslocaria a atenção médica da cura para a antecipação, sempre na esperança de remodelar os processos vitais por meio de dietas, fitness e demais intervenções preventivas ou corretivas, visando maximizar o desempenho dos organismos e aprimorando os resultados por eles alcançados.

Nesse processo, quaisquer humanos teriam elaborados para si graus de suscetibilidade, classificando todos os indivíduos como em risco e permitindo que os novos peritos formulassem definições para o que passaria a ser entendido como pré-pacientes. Tais pacientes teriam se libertado de seus próprios corpos e os transformado em estruturas sintetizáveis, simuláveis e, por extensão, programáveis. 
A molecularização e a otimização permitiriam ainda, segundo Rose (2013), novas práticas políticas: a etopolítica biológica. Esta redefiniria nossas relações conosco mesmos no sentido de nos compreendermos como seres cujo espaço interior - entalhado pela discursividade psicológica (ROSE, 2001) - seria constantemente sujeito ao autoexame de cada um segundo suas próprias crenças. Fundamentadas nos conselhos dos experts, as crenças invocariam nossa responsabilização conosco e com o futuro e, ao mesmo tempo, instituiriam um "meio social no qual novas formas de autoridade estão assumindo vulto" (ROSE, 2013, p. 46).

Entre as novas autoridades, Rose (2013) encontrou um tipo específico de expertise: os "peritos da vida em si mesma" (p. 47). Tais personagens atuariam como conselheiros, terapeutas e cuidadores que apresentariam opções cujas escolhas recairiam na responsabilidade dos indivíduos que assumiriam a tarefa de aprimorar seus próprios corpos. Assim,

[...] desde peritos em células-tronco até gerontologistas moleculares, de neurocientistas a tecnologistas da clonagem, surgiram novos especialistas do corpo, cada um com seu aparato de associações, encontros, periódicos, linguagens esotéricas, atores-estrelas e mitos (p. 49).

Convivendo no espaço público, divulgando seus conselhos na mídia, estabelecendo bandeiras para grupos de pressão e perpetuando clichês, esses peritos não seriam apenas médicos ou psicólogos, mas nutricionistas, promotores de saúde, ginastas, enfermeiros, paramédicos em geral que atuariam como conselheiros para assuntos como propensão a vícios, saúde mental, vida sexual, relações familiares, educação escolar, fertilidade, planejamento familiar, reprodução etc. Toda essa preocupação tornaria o aconselhamento uma espécie de ação premonitória cujo alvo, segundo Rose, não seria mais a vida, mas a vitalidade, a qual

[...] tem sido decomposta em uma série de objetos distintos e discretos, que podem ser estabilizados, congelados, amontoados, armazenados, acumulados, permutados, comercializados, através do tempo, do espaço, dos órgãos e espécies, dos diferentes contextos e empresas, no serviço de objetivos bioeconômicos (p. 64).

Consideramos que tal ação bioeconômica sobre a vida, quando estabeleceu a vitalidade como fundamento para a longevidade, o bem-estar e a produtividade, muito além de mercantilizar a relação de cada um com seu próprio corpo, acionou mecanismos próprios do funcionamento econômico atual no sentido de sofisticar as relações de consumidor que cada indivíduo tem com as especialidades somáticas. Dessa maneira, a livre escolha 
combinar-se-ia à busca de rendimento e apoiar-se-ia na securidade para garantir a produção de corpos adequados, produtivos, autônomos e prudentemente ativos. Corpos que dispensariam sua corporalidade em nome da sintetização daquilo que os referidos experts definem como estruturas componentes dos processos vitais.

Da imensidão de procedimentos vitais investidos pelos numerosos experts da vida contemporânea, voltamo-nos àqueles que se dirigiram à genética e à neurologia. Suspeitamos que daí podem advir robustas análises sobre a maneira como, historicamente, conectaram-se elementos fundamentais para compreendermos a atuação dos especialistas psicopedagógicos.

A fim de justificar tal suspeita, mais uma vez elegemos a companhia de Foucault (2001b), em cuja obra encontramos algumas análises sobre as mutações do saber psiquiátrico após meados do século XIX. Insinuou o pensador francês que, àquela época, estava em processo certo deslocamento do olhar médico-psicobiológico: do corpo disforme para o corpo incompleto.

Nos enunciados atinentes à psiquiatria do século XIX, Foucault (2001b) constatou um direcionamento de atenção cujo norte teria permitido aos psiquiatras redefinirem toda a sua lógica discursiva. Até então, visualizava-se o corpo do indivíduo anormal como um organismo marcado por estigmas de má-formação. A novidade estaria na substituição da teoria dos estigmas pela descrição de "uma espécie de desequilíbrio funcional do conjunto" (p. 381). Tal substituição ganharia visibilidade a partir do modo como se passou a compreender a influência do período infantil na produção das anomalias comportamentais dos adultos.

As teorizações psiquiátricas visualizadas por Foucault (2001b) justificavam as anormalidades como resquícios de atitudes infantis que, no caso dos psicopatas, teriam se fixado na personalidade e se manifestado em determinada ação desviante. Portanto, a psiquiatria moderna doravante passaria a tratar toda doença mental como vicissitude de desenvolvimento. A partir daí, a infância estaria no cerne das preocupações médicas. Concomitantemente, segundo Foucault (2001b), a genética auxiliaria a medicalização da psiquiatria, na medida em que passaria a fornecer os conteúdos para vasculhar algo - presente no corpo dos pais, dos ancestrais, da família, da hereditariedade - que pudesse explicar "o déficit geral nas instâncias de coordenação do indivíduo" (p. 397) e cuja perpetuação ao longo da vida produziria nesse indivíduo um estado permanente de anormalidade.

Assim, a psiquiatria medicalizada teria assumido um papel de aconselhamento, mas não propriamente dos desvios psíquicos. Nas palavras de Foucault (2001b), após a conquista da infância pelo discurso antecipador da genética, a psiquiatria "se torna a ciência da proteção 
científica da sociedade, ela se torna a ciência da proteção biológica da espécie” (p. 402). Uma proteção que dispensaria o corpo, reorganizando-o em termos de estruturas vitais marcadas pelo irrefreável desenvolvimento, seja geracional, seja etário.

O princípio da defesa generalizada da vida, próprio da aliança entre a psiquiatria e a genética já no século XIX, referenciou nossas leituras acerca das práticas antecipadoras da biociência. O intuito foi auscultar algumas modificações e repetições operadas pelo presente em relação aos primeiros tempos da genética. Nosso foco investigativo se conduziu a partir das associações entre a generalização de práticas preventivas - presentes na medicina moderna e na psicologia experimental - e os cânones que tais práticas instituíram para se visualizar a presente subjetivação escolar.

Os enunciados da biociência possuem grande circulação em meios acadêmicos ou em peças de divulgação científica. ${ }^{14}$ Das numerosas possibilidades de se abordarem as relações entre biotecnologia e ciências da vida, tomamos as práticas concernentes à genética e à neurologia no sentido de sopesar as invocações presentes no olhar biológico dirigido aos corpos humanos.

No que tange às novidades genéticas, a pesquisa de Sydney Brenner ${ }^{15}$ (2006) permitiunos visualizar algumas práticas significativas. $O$ autor relatou que, em se tratando da responsabilidade científica daqueles que estudam genética, certos procedimentos deveriam ser considerados em razão de suas discutíveis decorrências éticas. Deles, Brenner (2006) destacou três: a produção de alimentos geneticamente modificados, a medicina probabilística ou personalizada e as práticas de clonagem.

Acerca da manipulação genética para produzir alimentos, o autor dissertou sobre a possibilidade da forja de vegetais resistentes a determinadas agressões externas. É sabido que essa forja poderia produzir alterações perigosas para a saúde humana; portanto, em tal seara, a preocupação dos biólogos se limitaria a calcular a distância entre o risco e o benefício da utilização das tecnologias. A prática evidenciaria, segundo Brenner (2006), o intuito biotecnológico da síntese de vida e, no mesmo golpe, as limitações desse criacionismo

\footnotetext{
${ }^{14}$ Uma consistente mostra dessas práticas encontra-se na revista BioSocieties. A publicação, editada desde 2006 e capitaneada por Nikolas Rose, expõe uma profusão de artifícios voltados a discussões em torno das técnicas alocadas nas biociências e seus consequentes desdobramentos em processos contemporâneos de subjetivação. Em sua proposta editorial, observa-se a preocupação com as "implicações éticas, sociais e políticas da evolução das ciências da vida e biomedicina" (Disponível em: <http://www.palgrave-journals.com/biosoc/index.html>. Acesso em: 6 jan. 2014).

${ }^{15}$ Biólogo ligado ao King's College, em Cambridge. Foi laureado com o Prêmio Nobel de fisiologia e de medicina em 2002, por ter realizado, ao lado de John Sulston e Robert Horvitz, o primeiro mapeamento genético de um organismo multicelular, contribuindo para o início do Projeto Genoma Humano.
} 
biológico. Entretanto, a presença do conceito de risco, próprio das mais avançadas teorizações científicas, permitiria que tais limitações fossem divulgadas e os possíveis danos deixados ao livre-arbítrio dos consumidores.

Ao tratar os processos vitais fora dos corpos viventes, a biologia teria inaugurado a possibilidade de que cada indivíduo optasse por procedimentos preventivos segundo suas próprias decisões. É esse o caso, por exemplo, da extirpação de órgãos como a mama e o útero quando testes genéticos indicam propensão ao câncer nessas áreas.

Quanto à imbricação da medicina com a genética, Brenner (2006) afirmou que as orientações da bioquímica celular estariam progressivamente voltadas para a detecção de predisposições individuais para doenças. Segundo o autor, tal horizonte estaria longe de ser atingido, já que a mera procura por ele se apresenta muito mais útil às instituições de saúde e aos órgãos de governo do que aos próprios usuários. Brenner (2006) chegou a aventar que esse tipo de suposição seria tão quimérico, que se assemelharia a operar com "algo como um horóscopo biológico; algumas vezes eu o chamo de um genoscope" (p. 10, tradução nossa). Para o autor, portanto, a busca autônoma pela maximização corpórea transformaria os supostos pré-pacientes em consumidores, de modo que as quiméricas ofertas da bioindústria comporiam uma espécie de cardápio por meio do qual cada um escolheria suas crenças e, consequentemente, a intervenção antecipadora em seus próprios corpos.

Brenner (2006) ainda refletiu sobre a clonagem. Essa técnica estaria sendo utilizada nas pesquisas de medicina regenerativa para clonar órgãos sucedâneos àqueles que eventualmente teriam sido danificados. Segundo o autor, as experiências com células-tronco com vistas à geração de órgãos humanos extrapolaria a biotecnologia, evidenciando que o desenvolvimento científico nesse campo específico se alastra para espaços inimagináveis. $\mathrm{Ou}$ seja, novas práticas biomédicas demandariam uma profunda reconfiguração da relação "entre indivíduos, os corpos que eles habitam e as sociedades que eles criaram" (p. 12, tradução nossa).

Julgamos que, para além das possibilidades científicas - as quais, a se considerarem os apontamentos de Brenner (2006), estariam muito aquém do que esperam aqueles que anseiam por utópicas soluções advindas das novidades da botânica, da medicina e da genética -, a discursividade em torno dessas mudanças passaria ao largo das possibilidades propriamente técnicas. Ao apontar quão incomensuráveis e irrefreáveis as mudanças poderiam ser, o discurso biotecnológico ofereceria aos indivíduos a possibilidade de agirem sobre seus próprios processos vitais sempre na espera de um futuro promissor por parte da ciência. 
De acordo com Brenner (2006), porém, tais ações estariam longe de serem alcançadas; mesmo assim, somente o fato de serem apresentadas já dispararia crenças associadas à ideia de corpos em risco, abrigando processos vitais suscetíveis a prevenções e previsões de toda ordem. Esses corpos, supomos, oferecer-se-iam sempre dispostos ao autoexame, preocupados com propensões hereditárias e disponíveis à regeneração. Tudo isso aumentaria ainda mais o campo de atuação e, por conseguinte, a autoridade dos peritos da própria vida (ROSE, 2013).

Próximos à discussão sobre risco-benefício e responsabilidade dos cientistas, Barbara Prainsack e Gil Siegal (2006) ${ }^{16}$ - ambos pesquisadores dedicados a examinar as relações entre as políticas de saúde e os direitos dos usuários - estudaram duas aplicações da ciência genética: o Dor Yeshorium e o combate à talassemia, ${ }^{17}$ no Chipre. Em ambos os casos, os pesquisadores relataram o extenso uso dos testes pré-nupciais com o intuito de combater doenças genéticas.

O primeiro empreendimento refere-se a uma associação criada para combater a alegada prevalência do transtorno de Tay-Sachs ${ }^{18}$ na comunidade judaica. Apontaram os autores que o Dor Yeshorium disporia casais-membros da associação a um teste para averiguar a compatibilidade de suas uniões, apurando a propensão tanto ao Tay-Sachs quanto a diversas outras doenças. Diante da proibição religiosa da prática de aborto ou de seleção de embriões, o Dor Yeshorium teria se apresentado aos seus membros como um método eficaz para prevenção de diferentes anormalidades físicas: a escolha do parceiro sexual a partir de exames genéticos realizados pelo casal.

No mesmo sentido, Prainsack e Siegal (2006) analisaram os meandros que envolveram a política de combate à talassemia no Chipre, em 1980. Na análise, destacaram o consenso entre Estado e Igreja em razão dos relativamente baixos custos envolvidos na promoção de um amplo programa de testes genéticos baseados em exames pré-nupciais. A aparente unanimidade da população do Chipre em torno do procedimento demonstraria a atração que o cardápio biocientífico poderia exercer.

Nos dois casos, os autores preocuparam-se com aquilo que chamaram de acoplamento genético. Tal fenômeno referir-se-ia a "uma identidade genética que ultrapassa o nível do

\footnotetext{
${ }^{16}$ Barbara Prainsack é ligada ao Departamento de Ciência Política da Universidade de Viena; Gil Siegal, à Divisão de Ética Médica da Escola de Medicina de Harvard.

${ }^{17}$ Doença manifestada por uma anemia crônica cujas causas não se encontram nem na alimentação deficitária, nem na contaminação sanguínea ou por quaisquer outros meios de contágio. Atribui-se a talamessia, portanto, a uma anomalia genética no processo de produção de glóbulos vermelhos.

${ }^{18}$ Enfermidade neurodegenerativa cujos sintomas surgem próximo ao primeiro ano de vida. Normalmente, a evolução da doença de Tay-Sachs desdobra-se em comprometimento cognitivo, convulsões, cegueira e surdez, geralmente levando a óbito por volta dos 5 anos de idade.
} 
indivíduo e ocorre quando duas pessoas estão prestes a tornarem-se uma só carne" (PRAINSACK; SIEGAL, 2006 p. 21, tradução nossa). Encarada dessa forma, a genética ofereceria uma identidade que ultrapassaria o próprio indivíduo e o convocaria à responsabilização diante de sua herança, realocando suas decisões e uniões no campo das possibilidades biológicas.

Vislumbramos na neurociência outra seara discursiva em que a biologia, tomada como campo de possibilidades e de identidades, ganharia força. Nessa arena, é convencional afirmar a existência de bilhões de neurônios estabelecendo bilhões de sinapses em uma complexa rede de informações que constitui o cérebro, órgão centralizador das ações humanas e de suas respectivas funções corporais (DAMÁSIO, 1996; BEAR, 2002). As explicações neurocientíficas, mesmo quando assumem a intangibilidade de suas definições, sobejamente escoram nas operações cerebrais propostas de intervenções medicamentosas. Essa apregoada complexidade desdobra-se em recomendações interventivas que instigam à bioidentificação.

Em seu artigo Neurochemical selves, Nikolas Rose (2003) oferece uma análise que cruza dados do mercado mundial de psicofármacos, das polêmicas científicas a respeito da eficácia dos medicamentos, das estratégias de marketing das companhias farmacêuticas, das disputas jurídico-médicas em torno dos efeitos das drogas psiquiátricas e da definição de transtornos. Rose (2003) fez uma abrangente compilação para especular sobre a questão: “como nos tornamos si-mesmos neuroquímicos?” (p. 46, tradução nossa).

A partir de tal questionamento, o autor ponderou sobre a incessante busca pela especificidade de ação anunciada nos processos que envolvem a fabricação dos psicofármacos. Para tanto, compilou diferentes aspectos envolvidos nessa indústria, desde a criação da Clorpromazina - cujo alvo, na década de 1950, seriam os doentes agitados do Hospital de Sainte-Anne, em Paris - até a formulação do Prozac, ${ }^{19}$ medicamento produzido já sob a vigência da "hipótese serotonínica para a depressão" (p. 47, tradução nossa). Formulada na década de 1960, essa hipótese coroou, segundo Nikolas Rose, uma sequência de pesquisas voltadas ao entronamento da neurotransmissão como o segredo por meio do qual se estabeleceria uma ponte entre a neuroquímica e o comportamento. Tal ponte, apesar de infinitamente extensa e muito pouco consensual, teria se tornado chave para todo o desenvolvimento psicofarmacológico. Ou seja, a partir de uma reconhecida parcialidade, foi

\footnotetext{
${ }^{19}$ Antidepressivo cuja marca foi patenteada até 2001 pelo grupo Eli Lilly. Atualmente, é vendido no Brasil como o medicamento genérico Fluoxetina.
} 
estabelecida toda uma linha de pesquisa que permitiu a fundação de numerosos institutos, clínicas, laboratórios e, por conseguinte, sintomas.

Quanto ao consumo, Rose apresentou uma quantificação capaz de demonstrar números em permanente ascensão, tais como os da década entre os anos de 1990 e 2000, quando teria havido um crescimento no uso de psicofármacos de mais de $600 \%$ nos Estados Unidos e de 50\% no Japão, perfazendo um montante mundial de 49,1 bilhões de dólares no mercado desses medicamentos. Tendo isso em vista, o autor apresentou uma análise da progressiva participação das instituições estatais de saúde na demanda por drogas psiquiátricas, evidenciando como a desinstitucionalização do tratamento mental deu-se pari passu ao aumento do consumo de remédios.

Ao lado das hipóteses neurológicas, dos negócios e da assistência estatal, Nikolas Rose salientou as relações entre a produção de medicamentos e os efeitos esperados pelas drogas. Assim, deixou evidente uma intrincada ligação entre pesquisas científicas, aceitação pública, órgãos oficiais de controle e marketing das companhias farmacêuticas. A partir do jogo entre consumo e prescrição, o autor apontou a permanente luta dos empresários contra os órgãos reguladores estatais em razão do pendor ao vício, dos efeitos colaterais e da superdosagem, bem como das estratégias de rotulação e da emissão de bulas com avisos e proibições; tudo isso quase sempre instituído na barra dos tribunais, tendo em mira o par risco/benefício.

Nesse aspecto, segundo Rose (2003), ascensão e queda no consumo de diferentes medicamentos parecem ter sido eventos constantes no ramo. Desde o tranquilizante Miltown, ${ }^{20}$ propagandeado como "a aspirina para a alma" (p. 49, tradução nossa), até o Valium, ${ }^{21}$ que na década de 1970 se tornaria sinônimo de tranquilizante, os enunciados produzidos em torno dos psicofármacos associariam diretamente comportamentos indesejáveis à ação medicamentosa. O autor destacou, assim, um gradativo deslocamento nas estratégias de marketing das companhias farmacêuticas: do medicamento para a doença. Doravante, os psiquiatras seriam encorajados a depurar as comorbidades encontradas nos transtornos, os neurocientistas seriam incentivados a precisar as chaves moleculares das neurotransmissões e os grupos dos portadores dos transtornos ganhariam voz política e institucional.

\footnotetext{
${ }^{20}$ Licenciado pela Wallace Laboratories.

${ }^{21}$ Licenciado pela Hoffmann-La Roche.
} 
Em meio à pressão pelo aumento nas vendas, pela especificidade de ação dos princípios ativos, pelo incentivo do Estado, pelo controle dos riscos e pela viabilidade dos tratamentos, teriam se definido e redefinido critérios diagnósticos na mesma medida em que cresciam numericamente os transtornos aceitos pela comunidade científica. Todos esses esforços, segundo Rose, conjugar-se-iam na individualização tanto dos diagnósticos quanto dos efeitos esperados a partir da administração dos medicamentos.

A mesma aproximação entre psiquiatria e farmacêutica foi analisada por Emily Martin (2006), antropóloga norte-americana que investigou o modo como os americanos relacionavam-se com seus supostos desarranjos mentais e com os fármacos a eles correspondentes. Por meio da análise de pronunciamentos de pacientes, médicos e negociantes ligados à produção, à comercialização e ao consumo de psicofármacos, a autora analisou uma tendência à personificação das drogas psiquiátricas. Ponderando sobre discussões em torno de design, preço, ação medicamentosa e efeitos pretendidos, Martin (2006) descreveu como os psicofármacos teriam adquirido personalidade, fosse no texto das propagandas, fosse no relato dos pacientes sobre seus sintomas.

Entretanto, ela asseverou que a relação pessoal dos usuários com os psicofármacos, além de demonstrar a adesão identitária dos consumidores a seus remédios, abriria espaço para a ultrapassagem de suas próprias limitações.

[...] crianças, adultos e jovens americanos estão fazendo muitas coisas para aumentar suas capacidades mentais de maneiras específicas, tomando práticas de autogerenciamento, frequentemente procuradas para ajudar a si próprios por meio do uso de drogas fortalecedoras da mente (MARTIN, 2006, p. 274, tradução nossa).

Segundo a autora, a alegada complexidade do funcionamento cerebral parece ter sido desprezada por esse ramo de investigação. O encontro entre as especulações neurocientíficas e a indústria farmacêutica, nas acepções de Martin (2006), passaria longe da antiga relação entre doença e remédio. Os atuais psicofármacos estariam envolvidos em novas posturas dos indivíduos diante de seus próprios corpos. Não bastaria agora aceitar suas possíveis limitações, atrelar-se a elas, formar grupos de portadores dos transtornos e exigir direitos a partir dos déficits alegados. Tratar-se-ia, antes, do aprimoramento das habilidades e do fortalecimento funcional por meio da livre intervenção sobre o próprio corpo.

Nos relatos compilados por Martin (2006), os medicamentos comporiam parte da personalidade de seus usuários. Os médicos e as companhias farmacêuticas investiriam nesse apego pessoal pelos princípios ativos, criando coquetéis de drogas com dosagens específicas para cada caso, patológico ou não. Portanto, segundo a autora, as descobertas científicas desse 
campo teriam se tornado dispensáveis diante da escolha subjetiva dos pacientes. Relevar-seia, desse modo, a livre busca pessoal pelo alto rendimento, pelo bem-estar, pelo equilíbrio e, no limite, pela felicidade.

Conforme podemos supor, criar-se-iam processos de subjetivação que tangenciam os limites extremos da autonomia. Cada um desses si-mesmos neuroquímicos assenhorar-se-ia dos achados científicos de acordo com suas crenças, sua sede por novidades e sua pretensão de desenvolvimento pessoal. Em tal universo de práticas discursivas, não haveria espaço para imposições, manipulações ou ideologizações. Tratar-se-ia de um inusitado encontro de cada um com sua própria definição de individualidade.

No percurso desse encontro, chegamos à obra Muito além do nosso eu, cujo autor, Miguel Nicolelis (2011), pretendeu apresentar a nova neurociência que une cérebros e máquinas e como ela pode mudar nossas vidas. O cientista brasileiro dedicou-se a apresentar o percurso de suas pesquisas acerca da criação de uma interface cérebro-máquina-cérebro apropriada para movimentar instrumentos inanimados a partir da ação neuronal.

Nicolelis - detentor de extenso currículo no campo da pesquisa sobre neurofisiologia, informática médica, eletrofisiologia, sistemas sensoriais, sistema somestésico e próteses neurológicas - alcançou status de celebridade ao liderar o Walk Again Project. ${ }^{22} \mathrm{O}$ projeto congregou instituições dos Estados Unidos, da Alemanha, da Suíça e do Brasil em torno da mobilização de tecnologia e de recursos para produzir um exoesqueleto cujo manuseio por um jovem paraplégico deveria permitir seu caminhar por alguns passos, operando o mecanismo por meio de diminutos sinais elétricos emitidos por seu cérebro e captado por instrumentos capazes de transmiti-los a processadores e potencializadores de movimentos.

Planejada para acontecer em 12 de junho de 2014, data da abertura da Copa do Mundo de futebol em território brasileiro, a apresentação pública do projeto seria efetivada quando o dito esqueleto robótico possibilitasse que seu jovem operador caminhasse pelo estádio em que decorreria o jogo inaugural do torneio. O cume da demonstração adviria do momento em que o equipamento conduzisse ao pontapé inicial da competição.

A despeito do exíguo tempo concedido pela organização do evento e da parca cobertura televisiva - um flash de apenas 3 segundos -, o mecanismo robótico movimentouse e a perna híbrida tocou uma bola na lateral do campo. Para os espectadores que não sabiam da peripécia, a alegria estampada no rosto do rapaz - alcunhado de Iron Man pelos cientistas

\footnotetext{
${ }^{22}$ Informações oficiais disponíveis em: 〈http://vitualreality.duke.edu/project/walk-again-project〉. Acesso em: 20 ago. 2014.
} 
do projeto - foi o único indício de que algo importante estava acontecendo naqueles escassos metros da arena paulistana de futebol.

Para além de nos extasiarmos com as utopias biocientíficas ou mesmo com as soluções técnicas voltadas à correção de entes viventes, e mesmo desprezando os embates da comunidade científica acerca da precisão dos conceitos aí envolvidos, procuramos contemplar o projeto de Nicolelis em nosso debate, cujo mote seriam os atuais cânones da enunciação da vida como fato científico. Para tanto, dedicamo-nos a recortar apontamentos em que as descrições técnicas da complexidade neuronal apresentadas pelo autor ancoraram em inferências dirigidas à natureza humana e, por conseguinte, à possibilidade de seu aprimoramento.

Considerando um homem cujo "senso de eu e sua imagem corporal - não passam de criações fluidas e altamente plásticas, edificadas e mantidas pela mobilização de microeletricidade em um punhado de moléculas" (p. 39), Nicolelis (2011) delineou o cérebro em termos de uma orquestra no interior da qual populações de neurônios, em constante atividade elétrica, executariam sinfonias cuja harmonia permitiria a realização de operações motoras, cognitivas e sensórias. A visualização do cérebro na qualidade de um ambiente dinâmico em constante reconfiguração e suscetível a ações externas permitiu ao autor enunciar o senso do eu em termos da "sensação de habitar um corpo concreto e real que, no final das contas, não passa de mera ilusão mental" (p. 119).

Tal como os adeptos da realidade virtual, Nicolelis (2011, p. 125) adotou a compreensão do cérebro como o "mestre de todos os arquitetos da realidade". Para ele, isso poderia permitir, com o desenvolvimento das pesquisas em torno da inteligência artificial, o desprendimento de todos os invólucros orgânicos para garantir a tão sonhada imortalidade por meio da preservação dos pensamentos humanos em suporte cibernético.

$\mathrm{O}$ autor afirmou ter passado sua vida acadêmica visualizando, monitorando, medindo e decifrando "a melodia produzida pelos universos neurais" (p. 157), com o propósito de utilizá-la em prol da produção de interfaces cérebro-máquina e da intercessão em males como o de Alzheimer. Nesse percurso, garantiu ter aprimorado preceitos segundo os quais o dinamismo cerebral também serviria para que seres humanos assimilassem às suas representações mentais ferramentas que se prestariam a ser extensões de seus próprios corpos. Tal incorporação foi apregoada como exemplo para a referida libertação do senso do eu, proeza supostamente factível tanto aos humanos como aos demais primatas. Ou seja, na medida em que utilizassem ferramentas, tanto homens quanto primatas teriam desenvolvido uma organização neuronal capaz de permanecer por toda a vida. Assim, movimentos 
associados ao ato de dirigir, pilotar aviões ou usar próteses seriam incorporados e acoplados à própria autoimagem do humano, atrelando-se como parte intrínseca de sua corporalidade.

Partindo da crença no permanente rearranjo cerebral em face das interferências externas, o neurocientista sobrelevou o papel da evolução, tal como aventada pelos darwinistas, para compreender as contínuas e permanentes adaptações cerebrais diante das necessidades do meio. Resulta dessa acepção a concepção do cérebro como um órgão infinitamente complexo, mas plenamente reconhecível, de modo que o fluxo das moléculas ionizadas produziria tempestades elétricas passíveis de predição matemática, de elaboração computacional, de manuseio por engenheiros e de intervenção médica - sempre no sentido de mirar um futuro em que a humanidade, finalmente redimida do aprisionamento corporal, organizar-se-ia em uma aldeia de plena informação, plena saúde e pleno aperfeiçoamento cognitivo. Nicolelis, inclusive, alegou ter sonhado com uma brainet: espécie de rede informática que conectaria cérebros.

Muito além da patologia experimental - que, desde o século XIX, associou o corpo doente ao corpo anormal (CANGUILHEM, 2006b), procedendo ao decalque de uma suposta corporeidade ideal sobre o corpo vivido -, a neurociência apregoada por Nicolelis ultrapassaria qualquer idealização, projetando um humano híbrido, aprimorado e finalmente livre do confino corpóreo.

No artigo suprarreferido, Rogério Azize (2010/2011), ao dissertar sobre o atual desaparecimento do dualismo mente/cérebro, aventou que, na atual "concepção cerebralista de pessoa" (p. 566), tal dualismo dissipar-se-ia em nome de uma suposta sobreposição de hipóteses científicas que se dedicam a estudar a composição neuronal a fim de criar uma configuração individual do cérebro.

Acerca do dualismo cartesiano, Ian Hacking (2005) foi além. Comentando a respeito das tecnologias de produção de robôs no Japão e das criações do artista Gunther von Hagens, ${ }^{23}$ o autor sustentou, assim como Azize, que a tradicional distinção entre corpo e mente já adquiriu outro sentido, tendo em vista as coevas técnicas de intervenção na fisiologia humana.

Essas técnicas apontariam para uma corporeidade dividida em corpos análogos e mentes digitais (HACKING, 2005). Os corpos seriam vistos como um conjunto de órgãos

\footnotetext{
${ }^{23}$ Anatomista alemão que inventou a técnica de plastinação de cadáveres, procedimento por meio do qual o cientista consegue manter incorruptíveis corpos mortos. Gunther von Hagens tornou-se celebridade no campo artístico, pois os cadáveres por ele manipulados são apresentados em exposições onde os visitantes podem contemplar réplicas de esculturas clássicas, de gestos esportivos e de banalidades cotidianas reproduzidas e expostas em plástico o qual conserva intactos e visíveis os ossos, os ligamentos, as veias etc.
} 
interligados por emaranhados de válvulas, sangue, tubulações etc.; eles poderiam, inclusive, ser visualizados funcionando fora do corpo, sem a presença da mente. Esta, na acepção de Hacking, assumiu, nos ditos discursos, a metáfora computacional, redundando em um simulacro do dualismo cartesiano. Simulacro porque, nas técnicas modernas de manipulação do corpo e da mente, manter-se-ia a concepção dualista, a qual diferiria do modo de enunciação cartesiano ao evocar categorias exclusivamente materiais para compreender as ações geradas pela mente. Assim, tal concepção estaria bem distante daquela aventada por Descartes, uma vez que, para o filósofo, a mente não operaria com elementos materiais, senão com associações lógicas baseadas no conceito de atributos principais (HACKING, 2005), noção a partir da qual Descartes teria suposto uma correspondência direta entre estrutura e função. Desse modo, Hacking (2005) atribuiu a Descartes a tentativa de explicar a mente com base naquilo que ela produz: ora, se a mente é a sede da vontade, ela não poderia ser da mesma composição do corpo que produz movimento, fluxos e fluidos. A distinção cartesiana entre corpo e mente, segundo Hacking (2005), estaria em franca atividade, porém agora atrelada à materialidade dos algoritmos cibernéticos.

A reelaboração do cartesianismo por meio da cerebralização da mente é tema de outro bestseller da literatura neurocientífica: O erro de Descartes, de Antonio Damásio (1996), laureado neurologista português vinculado à Universidade de Iowa. O livro especula sobre as interconexões cérebro/mente de modo icônico para o senso comum neurocientífico. Sua visualização do cérebro encontrou um órgão composto por diferentes estruturas celulares, em conexão permanente e com funções específicas, cuja coordenação dependeria dos locais em que tais funções excitariam o córtex cerebral.

Em oposição a Nicolelis, Damásio (1996) centralizou suas pesquisas na busca por mapear funções mentais a partir das localidades em que elas deveriam ser produzidas no interior do córtex. Ou seja, para o português, embora o cérebro funcionasse de maneira integrada e simultânea em todas as suas porções, o déficit no funcionamento de alguma das partes comprometeria funções específicas, porque elas seriam, em sua opinião, comandadas pela área afetada.

A aproximação às teorias localizacionistas - descartadas por Nicolelis - permitiu a Damásio (1996) desenvolver sua concepção acerca dos marcadores somáticos. Estes seriam representações neuronais fixas e determinadas pela genética, cuja configuração correta garantiria a sobrevivência saudável do indivíduo. Tais marcadores preparariam os corpos individuais para decisões pessoais no sentido da preservação da vida, do afastamento do sofrimento e do equilíbrio biológico. 
Destaca-se que a suprema competência humana, segundo ele, seria a capacidade de tomar decisões. Por meio de seus experimentos - observação de pacientes que sofreram extirpação de parte do córtex e tiveram embotada sua capacidade de decidir; remoção de bocados do cérebro de primatas e ratos; figurações criadas por imageamento cerebral -, Damásio (1996) insinuou localizar no lobo frontal do córtex o local em que se processariam as decisões humanas.

Desse modo, ele pôde sustentar sua rejeição ao cartesianismo, já que a capacidade decisória - atributo mental separado do cérebro, segundo sua leitura de Descartes - seria enunciada como produção cerebral. Portanto, na neurologia defendida pelo cientista, aquilo que haveria de mais idiossincrático no humano, ou seja, sua aptidão para decidir, seria predeterminado por um arranjo neuronal constitucional e preconcebido geneticamente.

Por conseguinte, Damásio (1996) tratou a constituição da individualidade como algo restrito ao conjunto de representações que o cérebro produziria quando todo o corpo fosse submetido a estímulos ambientais: "se o cérebro é normal e a cultura em que se desenvolve é saudável, o dispositivo funciona de modo racional relativamente às convenções sociais e à ética" (p. 233).

Considerando a normalidade cerebral como o funcionamento ótimo do órgão, a salubridade cultural como garantia para o desenvolvimento dos corpos e a racionalidade como o correto uso das emoções no momento da tomada de decisões, Damásio (1996) conseguiu eliminar o dilema cartesiano, integrando a mente ao cérebro ou, em nosso entendimento, expandindo para todo o corpo - inclusive o corpo social - a cerebralização da subjetividade. Segundo o autor, em síntese, o programa das representações mentais, que expressariam a apreensão subjetiva sobre o mundo, estaria predeterminado na codificação genética. Desse modo, a completa e apropriada formação biológica, aliada à correta estimulação ambiental, promoveria a almejada normalidade corpóreo-social. Ademais, a transmissão seletiva, via estruturas genéticas, da bem-sucedida adaptação ao meio garantiria o permanente desenvolvimento humano, pois este estaria alinhado à eficiência da economia biológica.

Damásio (1996) aconselha, assim, a responsabilização de cada ente humano para com a determinação oferecida pela genética da espécie - convocação bastante antiga na cultura ocidental moderna. Talvez pudéssemos localizar aí a proeminência das concepções neurobiológicas para as já referidas dificuldades escolares.

Os discursos neurobiologicamente orientados, presentes em largos espaços do convívio social, parecem caminhar em direção à associação das idiossincrasias comportamentais com a biologia (LIMA, 2005). Nesse percurso, incontinenti, tais discursos 
operam também a partir do binômio estrutura/função, sustentando, segundo nossa hipótese, uma lógica discursiva que desdobraria dito binômio em outras polaridades, tais como: estímulo/resposta, norma/desvio, capacidade/déficit, imagem de si/caracteres somáticos, intervenção/reeducação, inclusão/sociedade de direitos, hereditário/adquirido, identidade/expertise biológica, processos vitais/vitalidade. Essas correspondências seriam entronadas como matrizes para o conhecimento de si por todos aqueles interessados em se reconhecerem na condição de humanos.

$\mathrm{Na}$ seara das dificuldades escolares e da cerebralização da individualidade, há, no presente, enunciados apresentados como guias ou manuais para o reconhecimento de disfunções cerebrais que levariam a tais dificuldades. Ditos textos utilizam cânones do linguajar neurocientífico para discorrer sobre transtornos ou déficits mentais (BENCZIK, 2000; MATTOS, 2001; ROHDE et al., 2003; SILVA, 2003), tomando por referência avaliações estandardizadas no intuito de definir "alterações neuroquímicas de origem provavelmente genética" (ROHDE et al., 2003, p. 13). O critério enunciativo nesse campo assentar-se-ia na sucessão de testes, avaliações e medições realizadas e publicadas pela comunidade científica a fim de estabelecer, com crescente detalhamento estatístico, repetições numéricas no interior de uma dada população.

Tais manuais e guias marcam sua onipresença no cotidiano escolar contemporâneo, dirigindo seus escritos a estudantes "desproporcionalmente vulneráveis a uma ampla variedade de complicações psicossociais" (ROHDE et al., 2003, p. 12). Os parâmetros dessa vulnerabilidade assentar-se-iam em hipóteses provenientes da neuroquímica do cérebro, sempre buscando destacar o substrato hereditário das supostas alterações constitucionais, o qual levaria à propensão de determinados indivíduos à discrepância diante de seus pares.

As aventadas suposições psiquiátricas no campo educacional parecem sondar uma interioridade cada vez mais profunda. Assim, quando diante de escolares com comportamentos inadequados às instituições educativas, os médicos-avaliadores da psique focalizam no funcionamento cerebral as razões para más condutas dos avaliados; uma vez no interior do cérebro, apresentam as anomalias das conexões neurológicas; especulando sobre as sinapses, buscam os condicionantes hormonais para a produção de tais ou quais neurotransmissores; ao chegarem às hipóteses bioquímicas, iniciam as suposições inspiradas na genética. Nesse percurso, chegam até mesmo a ultrapassar o pregresso determinismo genético, alcançando as mutações detectáveis por meio dos estudos moleculares (ROHDE et al., 2003). Como desdobramento lógico dessa trajetória, tais estudos justificam o recurso aos psicofármacos. 
Além dos discursos egressos da psiquiatria, outro campo discursivo se dedica a explicar a origem das dificuldades escolares. Trata-se do construtivismo (LA TAILLE; OLIVEIRA; DANTAS, 1992). O indivíduo observado por essa linhagem possuiria, desde a infância, determinadas tendências internas cujo desenvolvimento ocorreria a partir de suas relações sociais. Aí se destaca outra preocupação: a imagem positiva de si mesmo (COLL, et al., 2004). Ademais, um dos pontos de chegada desse approach consiste na compreensão da vida como um processo mensurável de aperfeiçoamento em direção a um homem racional e autônomo, que aceita a si mesmo e se ajusta ao meio em que vive.

Avizinhados a essa psiquiatria dos transtornos e à psicologia do desenvolvimento, encontramos, ainda no presente, enunciados que recorrem ao termo psicopedagogia a fim de definir seu campo. Tais enunciados comungam com as supracitadas especulações psiquiátricas; entretanto, os experts psicopedagogos dirigem suas intervenções para além dos cérebros em situação de transtorno, tendo em mira aqueles estudantes que, mesmo livres dos déficits, apresentam inapetências escolares. Para a constatação das alegadas dificuldades, desenvolve-se um conjunto de suposições ancoradas em avaliações padronizadas, mormente constituídas pela aplicação de testes atencionais, mnemônicos, fonoaudiológicos, de personalidade etc., com a finalidade de detectar as propaladas insuficiências individuais (GARCIA; JESUS, 2004). A fim de atuar diante de tais insuficiências, o saber psicopedagógico intervém no processo de aprendizado, balizando aquilo que define como etapas do desenvolvimento cognitivo (CHABANNE, 2008).

Entre os referidos psicopedagogos há uma marcante preocupação com o ensino gradual e progressivo. A crença no desenvolvimento por etapas orienta o profissional encarregado a respeitar o tempo de maturação psicoanatômica do educando com vistas a reforçar positivamente sua autoestima e, assim, impedir o bloqueio no processo de aquisição de conhecimentos. Portanto, além do substrato estatístico, do mapeamento cerebral, das hipóteses químicas e das considerações genéticas, os psiquiatras e psicopedagogos aqui referenciados comungam suas opiniões também quando conjecturam sobre o desenvolvimento humano.

A conexão que esse campo discursivo faz entre os fatores biológicos, psicológicos e educacionais, tal como anunciado no capítulo I, levou-nos a adotar como psicopedagógicos os enunciados que, desde a década de 1920 no Brasil, dirigiam-se à interface da saúde com a educação.

Para além do jogo entre verdade, representação e ilusão, consideramos que as visualizações do corpo - quando congregam técnicas de imageamento, suposições estatísticas, 
conjecturas genéticas, hipóteses químicas, especulações psicopedagógicas - delimitam um foco de experiência que distingue formas de subjetivação. Assim sendo, muito mais do que meros retratos, elas se elevariam à condição de referências para que nós, contemporâneos, estabelecêssemos narrativas sobre nós próprios, fundamentando nossas histórias pessoais no leque de opções apresentado pelos experts da vida biopsicofisiológica.

Especulamos, então, que a atual investida dos saberes neurobiológicos em direção ao comportamento humano possibilitar-nos-ia discorrer sobre alguns elementos que secularmente teriam habitado os dizeres e fazeres em torno do processo de ensinoaprendizagem. Nesse sentido, faz-se fundamental redefinir, segundo nossos próprios parâmetros, o já mencionado termo bioidentidade: aquilo que se criaria quando se considerasse o corpo humano como um sistema suscetível ao conhecimento biológico. Para além dessa definição, intuímos que se poderia recorrer à noção de bioidentidade para nomear um fazer humano interessante à análise ora em pauta: narrativas verdadeiras sobre si.

Entre os diferentes modos de se discursar, encontramos alguns especialmente potentes no que concerne às reverberações. O jornalismo, a urbanidade, os cerimoniais, as cartas, as entrevistas, os filmes, a filosofia, a pedagogia, enfim, os diversos campos do convívio humano viabilizariam modos de discursos díspares, intercambiáveis, impositivos. No caso das narrativas acerca do próprio corpo, armar-se-ia uma vigorosa fonte de enunciados, um manancial de verdades, uma vertente propositiva cuja apresentação suscitaria que cada qual se individualizasse a partir de uma noção de natureza generalizadora.

Assim, ao se produzirem visualizações do corpo, aventar-se-iam bioidentidades; na medida em que se ouvissem as batidas cardíacas, propor-se-iam bioidentidades. A pressão sanguínea, a suficiência respiratória, o equilíbrio cinemático, a velocidade das respostas, a composição dos gametas, a motricidade, o impulso sexual, o apetite, a disposição, o sono, o volume de gordura no sangue, a taxa de espermatozoides no sêmen, a capacidade de raciocínio, a necessidade de descanso, o stress, a presença de células cancerígenas, os vícios, os exercícios, a propensão à diabete, a profusão, a depressão mentais: todos esses fatores, quando associados à longevidade, à prevenção de males futuros, à criação de reservas biológicas, ao aprimoramento do desempenho, ao bem-estar e à autoestima, poderiam ser tomados como poderosos cânones bioidentitários.

A bioidentidade, nesse sentido, teria instituído algo como uma linguagem com a qual se descreveria o próprio corpo. Ela seria um dos modos mais convincentes pelo qual se poderia falar sobre si numa sociedade como a nossa. Ao dizer sobre si recorrendo a componentes biológicos, uma pessoa poderia explicar para qualquer um os motivos de suas 
dores, de suas limitações cognitivas, dos impedimentos de movimento. Tomando como seus os enunciados dos especialistas, os indivíduos bioidentificados poderiam compartilhar curas, dividir agruras, trocar receitas.

O corpo biologicamente enunciado estaria, assim, aberto à visualização voluntária; o desejo de ver a si mesmo teria seu auge em tempos de bioidentidade. Ao permitir comparar todos os corpos, os vetores da bioidentificação poderiam interferir em campos díspares: da medicina legal à educação, da legislação ao juízo, da agricultura ao fitness, da administração pública ao resguardo privado.

No universo médico, por meio da bioidentidade estabelecer-se-iam regimes, restaurarse-iam funções vitais, aplicar-se-iam remédios, definir-se-iam políticas populacionais. Sobretudo as ciências seriam poderosas matrizes de bioidentidade: a matemática com a modelação estatística, a química com as simulações, a física com suas leis, a geografia com suas topologias, a biologia com seus enxertos, a história com suas progressões. Todas elas, ao absolutizar suas soluções, generalizar seus enunciados e, principalmente, naturalizar seus objetos em nome de um suposto esclarecimento acerca da humanidade, disparariam propostas de intervenção de cada indivíduo em seu próprio corpo.

Uma vez conquistado o cérebro pela lógica bioidentitária, operar-se-ia uma intervenção sumamente incisiva. Manipular a dor, estabelecer reflexos, construir sinapses, desviar impulsos, restaurar correntes elétricas, condicionar reações, antever crises e apagar a vigília passariam a ser consideradas ações voltadas a tornar saudáveis a todos e a cada um. Uma salubridade ainda mais sofisticada, pois abonada pelos limites e justificada pelas capacidades pessoais.

Os indivíduos, quando assumidos no interior de alguma bioidentidade, imediatamente passariam a integrar uma população, responsabilizando cada um pelo grupo a que pertence. Identificar-se por meio de seu corpo biológico seria o mesmo que produzir-se como um espécime humano: um ente cujo funcionamento seria detectável e, portanto, cuja vida seria aprimorada segundo a ação de si sobre si mesmo.

Tudo isso, cremos, não teria se passado caso a cultura ocidental não tivesse conhecido a visualização psicopedagógica estabelecida na discursividade disparada pelo movimento por uma Escola Nova, tal como aqui discutimos. 


\section{Considerações finais}

Fragmentar tecidos, enquadrar comportamentos, mapear mecanismos. Extrair dos tecidos a organicidade de seu funcionamento, testar respostas a perguntas padronizadas, enfocar camadas de superfícies orgânicas: eis as operações dispostas às carnes em nosso tempo.

Na cultura ocidental, desde pelo menos a alvorada do século XIX, o corpo, tal como o observam os clínicos, tem sido um manancial donde brotam variados discursos (FOUCAULT, 2004b). Estes instalaram demarcações que historicamente sustentaram práticas cujas aplicações estenderam-se para vastos e inusitados campos culturais, no interior dos quais operaram potentes intervenções dirigidas às vidas daqueles que incorporaram tal discursividade. Entre eles, os anatomistas. Com seus bisturis, ao finalizarem as incisões, dispõem nas bandejas suas hipóteses acerca daquilo que matou o detentor da carcaça. Algumas causas são evidentes: um tumor, uma oclusão, uma má-formação. Nem sempre, porém, as evidências se mantêm; quando encobertas, as causas disparam hipóteses sobre a morte que concomitantemente se convertem em inventários sobre a vida.

Os posicionamentos dos cortes nas autópsias foram padronizados por clínicos eminentes e formaram, no correr do tempo, o cânone das alocuções patológicas ou cirúrgicas. Cânones anatômicos sustentam suposições contemporâneas: de legistas a educadores, de nutricionistas a administradores. Tribunais, escolas, clínicas e repartições abdicam de seus motes específicos quando a vida orgânica comparece em suas alegações. Nessa via argumentativa, a morte anatomicamente definida é utilizada como gabarito para a visualização da vitalidade.

Ademais, historicamente, quando a lógica anatômica se combinou à psicopedagogia, outra realidade se produziu: o corpo do infante educável. Este, para os psicopedagogos, deveria ser visualizado sob o viés da conduta. Realizada a combinação, apontaram-se olhos para a expressão escrita, a resposta oral, a manifestação da vontade, a criatividade, o desempenho nos exercícios, as incapacidades, as facilidades, os medos etc. Numerosos foram os aspectos da conduta tornados visíveis pelos psicopedagogos. Desde o despontar do século $\mathrm{XX}$, as visualizações psicopedagógicas produziram medidas, observações e experimentações cuja objetividade, escorada em teorizações e previsões, aportou na comparação entre tamanhos, gestos e respostas esperadas para idades, capacidades e expressividades.

Classificação, enumeração e hierarquização iluminaram, assim, as tabulações da psicopedagogia. Quando atravessados pela anatomia, os talhes psicopedagógicos, análogos 
aos do bisturi, realizaram cortes, graduaram desenvolvimentos e estabeleceram comportamentos esperados para as diferentes faixas etárias. À luz desse foco, os corpos ganharam outra temporalidade, diferente daquela observada pela anatomia, na qual o desgaste teria como limite a putrefação. Para a psicopedagogia, ao contrário, o passar do tempo foi positivado como expansão vital.

Das formas de visualização do corpo que nos intrigam, há também a neurociência, cujo horizonte, no presente, dedica-se à matematização das estruturas orgânicas. Sustentada por dados produzidos por ciências como a biologia, a química, a física e a cibernética, a neurociência - quando aplicada ao exame da anatomia ou da cognição - permite a formulação de hipóteses moleculares a fim de descrever o funcionamento de estruturas orgânicas e anímicas. Para tanto, embrenha-se em circuitaria elétrica, supõe movimentos, demonstra conexões iônicas, induz reflexos, antecipa comportamentos.

Assim procedendo, o cânone cibernético permite conjecturar desenvolvimentos e presume resultados, explicando o aprendizado, a lembrança, a sagacidade e a simpatia por meio de um jogo entre automatismos, respostas e decisões. Esse mesmo cânone, ainda, lastreia a produção de fármacos, venenos, tonificantes e fortificantes, além de registrar o corpo vivo em movimento, filmar fluxos, monitorar ritmos.

Dentre as incisões das lancetas, as listas das avaliações e os algoritmos da informática, emergem os escolares: fisiologias em aperfeiçoamento, condutas em adequação, posicionamentos em enquadre. Corpos em decomposição abertos à laceração reparadora, extirpadora, liberadora. Gestos formulados em exercícios, em condicionamentos, em ortopedia. Cérebros permeáveis às substâncias, aos raios e às interrupções de circuitos. Livres expressões dispostas a estudo.

Daí a possibilidade de se definirem infantes como naturezas seculares e complexas envolvidas em cisões. Estas, quando abrigadas nos critérios anátomo-psico-proteicos, convidam todos a acompanhar o longo caminho que vincula cada indivíduo à sua própria espécie, à sua própria normalidade, à sua própria vitalidade.

No desdobramento desta investigação, voltamos nossa atenção às práticas de visualização corporal presentes na anatomia, na psicopedagogia escolanovista e na cibernética. Por conseguinte, interessou-nos analisar a produção de corpos cujas modelações estiveram escoradas em conjecturas acerca daquilo que poderia, desde o século XIX ocidental, ser nomeado como corporeidade humana, discente, cidadã.

Obsidiados por Joseph Paul Jernigan, Frankenstein e Clifford Beers esforçamo-nos para esboçar algumas linhas para uma genealogia do homem aprimorável. Vejamos. 
Ao invocarmos o corpo exposto em 1818, forjado pela pena de Shelley, visualizamos um vestígio perfeitamente manifesto, porque desaparecido. Um corpo apenas de vísceras, de fluxos, de estruturas ósseas, de músculos em putrefação, pus e catarro. Antes ainda do sangue ser tomado por hormônios, antes dos marcadores somáticos, antes das enzimas demonstrarem suas ações, antes das células serem microscópicas, antes dos cromossomos serem aventados, antes de existir a ciência bacterial, virótica, molecular, farmacológica e modificadora, os médicos observavam os corpos doentes e supunham um funcionamento orgânico a partir dele.

Nos alvores do século XIX, médicos reivindicavam o direito exclusivo de abrir os cadáveres, de aplicar as ataduras, de corrigir as fraturas. Emergiu nas memórias da Imperial Academia de Medicina, no Brasil novecentista, uma vontade explícita de oficializar o trato com o corpo dos súditos. Com a institucionalização da medicina no Brasil, somente asclépios autorizados puderam realizar suturas, partos, desobstruções, ressurreições. Esse fato não seria de pouca monta. Afinal, sem a oficialização da medicina, cremos, não teria sido possível fundar uma instituição como o Serviço de Ortofrenia e Higiene Mental, no Rio de Janeiro de 1934. Não teriam os higienistas, a mando de Arthur Ramos, tido licença para entrevistar os escolares sob sua responsabilidade: não os examinariam, não convocariam nenhum pai para conversas, não produziriam advertências, não estabeleceriam quaisquer regulamentos sanitário-escolares, não aconselhariam exercícios regeneradores.

$\mathrm{O}$ direito dos higienistas, antes de tudo, foi um fato médico: direito de atuar sobre corpos jovens considerados em adoecimento ou em risco de adoecer. Sem a higiene - ciência com direito médico sobre o corpo dos urbanos - não se teria realizado congressos, campanhas, feiras e outros eventos para salubrizar os modos das massas citadinas nos inícios do século XX, no Sudeste brasileiro.

A corporeidade cerebralista reivindicada por Clifford Beers teria justificado toda a sanha intervencionista dirigida àqueles que, ligados a alguma instituição - fosse familiar, profissional ou escolar -, insistiam em divergir do comportamento esperado pelos coletivos a que se vinculavam. Antes de tudo, Beers pleiteou o direito a um corpo livre, longe dos internamentos; um corpo capaz de resistir à autodestruição, suficientemente forte para ultrapassar os medos, hábil para participar ativamente em prol de sua comunidade e responsável pelo equilíbrio das próprias emoções. A liberdade ambicionada por Beers deveria ser vivida com intensidade em instituições educativas. Estas, quando assumiram a responsabilidade pela potencialização das individualidades psíquicas dos seus pupilos, tornaram-se repositórios para díspares utopias regeneradoras, contanto que inspiradas na higienização de corpos e hábitos. 
No Brasil, o corpo do alunado escolanovista emergiu portando o mesmo status orgânico-oficial que os acadêmicos da medicina imperial estabeleceram para o corpo doente dos súditos urbanos. Sob a batuta de Lourenço Filho - exercendo recortes na psique análogos aos dos anatomoclínicos efetuados na carne -, os psicopedagogos esquadrinharam, a partir dos processos mentais, as tendências de cada qual dos infantes em demanda por escolarização. Ditos processos, constituídos como basilares para a cognição, foram progressivamente se liberando de seus invólucros anatômicos. A própria distinção realizada por Arthur Ramos entre anormais e problemáticos explicita esse movimento.

Ao associarem a ideia de humanização à de progressão, os especialistas autorizados a conduzir o aprendizado marcaram a educação, ao mesmo tempo, como atributo humano e como necessidade social. Doravante, a educação foi tratada não apenas como direito, mas também como obrigação a todo aquele que pretendia conduzir-se do estado de infante para o status de adulto em nível natural e do status de selvagem para o de cidadão em nível social.

Ademais, nas alocuções escolanovistas aqui analisadas, sempre esteve presente a instigação ao autogoverno como ponto de chegada para quaisquer das iniciativas educacionais. Tal ditame, conforme sugerimos, estabeleceu outra conexão, basilar na era da educação científica: o vínculo entre humanização e autonomia. A partir daí, a liberdade tornou-se lugar-comum para educadores e psicólogos empenhados em aconselhar modos saudáveis para corpos supostamente aprimoráveis.

As relações da educação com temas como direito público, imperativo social, humanização, liberdade individual e convocação ao autogoverno parecem ter emergido no contexto em que as práticas higienistas - médicas, sobretudo - organizaram os fazeres escolares. De acordo com nossas reflexões, talvez residam nessas relações as condições de possibilidade para a emergência do homem aprimorável de nosso tempo.

Senão, vejamos. Conforme as práticas apresentadas no capítulo $\mathrm{V}$ desta tese, quando se descreveu a cidadania biológica, referiu-se aos direitos exigidos por determinados grupos a terem respeitadas suas demandas, se apoiadas em uma dada especificidade orgânica. Quando Lourenço Filho - e boa parte dos pedagogos atuantes em sua Bibliotheca - propôs a organização de classes homogêneas, a justificativa para a seleção repousava no resultado aferido nos testes para verificar capacidades. Ou seja, fundamentalmente, auscultavam-se aptidões psicofísicas consideradas fundamentais para o aprendizado.

Nos tempos da Escola Nova, os testes discriminavam. Hoje, aquilo que servia para discriminar é tido como atributo pessoal e, dessa forma, digno de respeito. Modificaram-se os 
argumentos e os encaminhamentos para as diferenças, mas o critério das distinções continua o mesmo: um corpo portador do direito de se desenvolver plenamente.

Outro aspecto que, em nossas especulações, compôs elementos próprios da subjetividade em aprimoramento foi a interdependência entre a interioridade e a exterioridade, sendo a primeira expressa pelas leis psíquicas e a segunda, pelo entorno social. No caso da psicopedagogia constante na Bibliotheca de Educação, nenhum dos autores descartou o jogo permanente entre processos mentais e ação social. Tal jogo sustentou aconselhamentos relacionados ao ensino conforme a idade, o gênero e a classe social. Desdobraram-se desses aconselhamentos definições relacionadas à orientação profissional, à adequação moral e a atitudes civilistas. No capítulo $\mathrm{V}$ aventou-se, nesse sentido, o despontar de uma etopolítica biológica, na condição de um movimento em que os consumidores das novidades propagadas pela expertise biológica escolheriam para si tais ou quais aditivos - fossem químicos, fossem exercícios, fossem dietas etc. - apropriados para alterar a capacidade produtiva, a sensibilidade, a atenção, sempre no sentido de permitir aos consumidores das novidades biocientíficas ultrapassassem os limites impostos pelas convenções sociais em direção a maiores eficiência e satisfação. Supomos que, sem a crença no intrínseco jogo entre psique e sociedade, tal ultrapassagem seria impensável.

Ao lado da saúde como direito e da vida como permanente fluxo psicossocial, a definição do homem-espécie também nos parece fundamental para o afã aprimorador dos tempos atuais. A recorrente máxima da repetição da ontogênese pela filogênese, tantas vezes presente nos escritos da Bibliotheca de Educação, foi apresentada como o sentido natural de todo desenvolvimento humano e, por conseguinte, como um caminho inevitável e necessário. Tal movimento natural reapareceu de modo similar no universo das acepções neurocientíficas, particularmente quando Nicolelis e Damásio evocaram o darwinismo para dissertar tanto acerca das representações mentais quanto a respeito dos marcadores somáticos. Ditas estruturas foram tratadas em termos de predisposição neuronal inerente a cada qual dos humanos, já que forjadas na sucessão evolutiva das numerosas gerações que depuraram a composição cerebral do humano no presente.

Também nos pareceu constante outra associação evocada pelo escolanovismo e recorrente no presente: o avassalador processo de constituição do indivíduo na condição de ente livre, instituído desde há muito na cultura ocidental. No caso da década de 1920 brasileira, o insuflar das liberdades mostrou-se inconteste. Nenhuma das alocuções pedagógicas contidas no arquivo avaliado deixou de mirar as individualidades livres. Estas funcionaram, seja nos gabinetes de higiene mental, nos laboratórios de psicologia 
experimental ou mesmo nas instituições de ensino, como parâmetros a partir dos quais todas as comparações seriam possíveis. Em liberdade, os alunos manifestariam suas idiossincrasias, seus interesses e suas propensões. Com base nos gestos e gostos individuais, os teóricos escolanovistas formularam suas suposições e realinharam seus estímulos. O resultado foi a fixação da noção de potencialidade, segundo a qual cada indivíduo guardaria em si mesmo um quantum de possibilidades ainda inexplorado e acessível apenas a ele mesmo, desde que devidamente estimulado por seus educadores.

Da mesma forma, no presente, a vontade de ser livre está intrinsecamente atada à busca pela melhoria de desempenho. Agindo e reprogramando os próprios corpos, os consumidores das novidades biomédicas estariam se libertando das amarras tradicionalmente atribuídas às suas naturezas. Redes de cérebros, bancos de órgãos, planejamento genético e coquetéis psicotrópicos seriam algumas das ações dispostas àqueles que resolvessem agir sobre seus próprios corpos com o fito de ultrapassar os aprisionamentos corpóreos. Todo o jogo composto pela conquista de direitos, pela assimilação social, pela crença na humanização e pela afirmação da autonomia pareceu-nos desembocar, tanto ontem quanto hoje, em práticas acirradas de autogoverno.

Não consideramos tais práticas simplesmente como ações que obrigariam os indivíduos modernos - sejam estudantes nas escolas modernas, sejam indivíduos contemporâneos - a abrigarem em si mesmos modelos, regulamentações ou representações adventícias às suas próprias vontades. Em relação às análises dos discursos psicopedagógicos e da atualidade biomédica, entendemos o autogoverno como composto por práticas por meio das quais cada um constituiria uma equipagem de verdade e agiria sobre o próprio corpo, comprovando em si mesmo o caráter verídico dos discursos que assumisse e tornando-os eficazes e produtivos segundo suas próprias concepções.

Evidentemente, a captura da individualidade pelos discursos médico-pedagógicos não se baseia apenas em políticas intraescolares. Tais políticas forjam-se no embate com conformações de poder que também se exercem por meio de imposições, modelações e simbolizações, conforme afirmaram os autores dos 56 artigos discutidos no capítulo IV. Entretanto, observamos em tais artigos certa louvação do direito à educação, à conquista da humanização, ao exercício da autonomia e à liberdade de escolha quando os pesquisadores se dirigem propriamente a ações escolares.

Tratando todos os enunciados como cânones da visualização que eles projetavam, fincamos pé na crença no arbítrio intrínseco a todos os discursos. Em termos de arbitrariedades, o capítulo IV possibilitou-nos imagear uma maneira consensual de tratar as 
práticas atinentes à Escola Nova. Tal consenso articulou-se em torno do sobredito olhar assimétrico para o poder. Por meio dessa perspectiva, pareceu-nos que a Escola Nova teria incorporado os métodos higienistas como ações exteriores às práticas escolares, cujos desdobramentos comprometiam subjetividades.

Seja por meio da denúncia do aburguesamento, da normalização, do autoritarismo ou do disciplinamento, os artigos se ativeram a associar as alocuções escolanovistas aos enganos do poder, aos preconceitos, à violência simbólica ou às representações. Eles pareciam discorrer sobre o desvio de algo que, em essência, fora ou deveria ser diferente.

Caso tivéssemos utilizado os cânones estabelecidos nos 56 artigos, teríamos visualizado, no arquivo formado pela Bibliotheca de Educação, teorizações positivistas, instruções cientificistas, racismos desbragados. Teríamos constatado proclamações liberais, projeções burguesas, atos discriminatórios, aprisionamentos hospitalares. Teríamos vislumbrado o rigor dos exercícios em escolas estatais, oficiais e disciplinares. Teríamos acompanhado repetições, influência de órgãos reguladores, autoritarismo de professores, orientações gerais dos burocratas. Teríamos ouvido punições, regras, contenções e proibições.

Entretanto, visualizamos também estudiosos do espírito, propostas libertárias, tratamentos igualitários. Contemplamos apelos à segurança nacional, à escola democrática, popular e prazerosa. Observamos incitamento à criatividade, apoio a iniciativas públicas, facilitadores no lugar de mestres, pedagogos na direção das reformas. Acompanhamos o despertar de vontades e exortações à livre expressão, aos estímulos, às respostas.

No jogo das certezas e das narrativas, parece que nos desvencilhamos completamente da fixação no tema que originara a presente investigação.

Se tomássemos esta tese como mero esforço de aprofundamento temático, teríamos simplesmente acrescentado mais alguns - e poucos - dados à pujante produção discursiva voltada para a história do escolanovismo brasileiro. Ao final do trabalho, porém, aventamos que seria ineficaz manter as metodologias convencionais diante do objeto a que nos propomos analisar.

A fim de refletir sobre a emergência de um personagem atual - o homem aprimorável -, decidimos não simplesmente vasculhar heranças, jogos de sentidos ou posições naturalizadas. Resolvemos enveredar pelos cânones de visualização dos corpos em exposição por meio das narrativas que tomavam tais corpos como objeto de estudo. Recolhemos definições, conceitos e determinações quando imergimos nas alocuções da psicopedagogia escolanovista. Ao mesmo tempo, angariamos críticas, rememorações, reconstruções e desconstruções quando imergimos nos enunciados contemporâneos dirigidos à Escola Nova. 
Desde Vale (2009) até Ribeiro (2013), acompanhamos o tratamento da Escola Nova como um projeto decaído. A possibilidade real de disseminar uma política equânime no campo educacional - incluindo o proletariado no acesso à escola pública; centralizando os planos escolares no aluno; espraiando o aprendizado da democracia; modernizando os projetos pedagógicos - teria sido subjugada pela hegemonia burguesa, a qual, por sua vez, teria transformado o sistema educacional brasileiro em uma reserva ideológica de sua própria classe. Assim, as práticas educativas teriam sucumbido ao higienismo, de modo que os signos de modernidade estabelecidos pelo imaginário burguês teriam confinado a educação a uma função ortopédica por meio da qual se imporia o projeto de salvar um país doente. Tal percurso decadente teria instituído no inconsciente coletivo uma marca da segregação, tanto social quanto racial e, por conseguinte, impediria um projeto societário popular de educação pública. Dentre os principais elementos dessa imposição burguesa, os autores dessa linhagem sobrelevaram a função de negação da cultura dos subalternos realizada pelo modo como se produziram e aplicaram os testes psicológicos nesses tempos.

Os testes, portanto, segundo a visualização imersa em cânones ideológicos, seriam meros instrumentos para propagação da mentalidade burguesa. Limitou-se tal visualização a denunciar as abordagens psicológicas que teriam mantido a adaptação dos estudantes à ordem burguesa, afirmando-se assim que os testes somente operavam a inculcação de valores burgueses na cultura popular. Tal olhar analítico fixou-se nas representações sociais contidas nas perguntas presentes nas testagens. Desconsiderando a necessidade de se questionar a produtividade efetiva dos testes e das demais práticas escolanovistas, limitou-se a denunciar posicionamentos ideológicos e seus possíveis vínculos políticos.

Consideramos, conforme sobredito, que as práticas discursivas escolanovistas, nas quais tiveram centralidade os testes psicológicos, perpetuaram na cultura educacional a crença em processos vitais como atributos inerentes à composição humana. Muito além do estabelecimento de representações preconceituosas - cuja superação apenas demandaria a boa vontade ou a conscientização crítica -, consideramos que as criações escolanovistas alcançaram força em razão de terem se tornado cânones para um tipo de visualização do homem no cerne da qual a educação estabeleceu-se como necessidade imperiosa. Tal operação, conforme aventou Jurandir Freire Costa (2000) no que se refere à temática da saúde, teria condensado todo e qualquer posicionamento político a proposições imersas no circuito sociabilidade - corpo individual - aprimoramento pessoal.

A perspectiva ideológica da crítica à Escola Nova conviveu em nosso arquivo com um approach em clara oposição a ela. Nos artigos compilados, apercebemo-nos de uma vontade 
persistente de separar as ideias de Dewey das assertivas ideológicas contidas na Escola Nova. Os textos próximos à linhagem apresentada por Marcus Vinicius da Cunha são exemplares nesse aspecto.

$\mathrm{Na}$ tentativa de afastar a filosofia deweyana de um suposto cientificismo experimental e estreito, Cunha e seus colaboradores substituíram alguns elementos daquilo que pretendiam criticar por outros, mantendo significados cujo funcionamento foram tidos pelos autores como perversos. Senão, vejamos: ao isentar o pensamento de Dewey do racionalismo científico/experimental, tais autores, cremos, atrelaram diretamente a experiência individual ao modo de vida democrático, vendo neste a ocasião privilegiada para se levar a cabo uma formação humana inerente à sua natureza - uma natureza em progresso, cujo desenvolvimento acompanharia o despertar de potencialidades tipicamente humanas.

Tal olhar para as aptidões/potências viabilizaria um modelo educativo no qual a história da ciência seria tomada como analogia para o desenvolvimento individual. Dessa maneira, quando Cunha e seus companheiros atribuem às ideias de Dewey uma proeminência da influência social sobre a constituição da individualidade, eles estão tratando o pedagogo norte-americano como um pensador que tomaria a sociedade como lugar onde uma razão coletivamente construída prepararia educandos livres e, por conseguinte, propensos à vida democrática. Destarte, os referidos autores findam por estabelecer a democracia como único modelo capaz de garantir o pleno, racional, livre e progressista convívio das individualidades humanas. Além disso, nesse enfoque, a sociedade seria tida como fator constitucional da natureza do educando e, portanto, como promotora tanto do progresso social quanto do aprimoramento pessoal.

Esse tipo de análise - na qual o pensamento deweyano é tomado como antípoda de uma educação tecnicista e psicologizante, e, ao mesmo tempo, promotor de uma sociabilidade profundamente humanista - tratou o democratismo de Dewey como ponto de chegada de um modelo educacional em que a fisiologia individual, a tendência etária, o meio social e a vontade individual são tidos como fundamentos para a construção de comunidades nas quais a adequada vivência seria internalizada em termos de predisposição pessoal para um modo de vida específico: o democrático.

Considerando plausível esse circuito formado pela fisiologia-predisposiçãosociabilidade-autonomia, torna-se plenamente compreensível a inserção de Dewey na coleção reunida por Lourenço Filho. As ideias do autor estadunidense, aventamos, teriam fundamentado a lógica segundo a qual os estímulos do meio interfeririam diretamente na potencialidade fisiológica, levando à cognição. Desse modo, coerente com o espírito da dita 
coleção, a democracia seria tomada como peça-chave na constituição de uma natureza humana reconhecível, enunciável e, enfim, modificável em direção ao progresso, ou seja, uma natureza medicalizável.

O apanhado formado pelos 56 artigos foi encerrado com o conjunto de textos que partiu de Spazziani (2001) e chegou até Bassinello (2004). Tal sequência foi por nós constituída em razão das referências nelas explícitas às teorizações foucaultianas. Ditos autores, ao criticarem a generalização do higienismo na passagem do século XIX para o século XX, tomaram-no como um manancial de representações acerca da vida escolar e urbana que então despontava.

As representações higienistas, segundo tal linhagem interpretativa, teriam contribuído para a disciplinarização dos escolares, ação que teria se espraiado por meio da inculcação de hábitos nos alunos modernos. Dessa forma, os corpos infantis teriam se convertido em objeto de manipulação e condicionamento por instituições que operavam com as referidas representações fabricadas.

Tais autores visualizaram a penetração do discurso médico nas escolas modernas em termos de uma ampla obra de modelagem. O empreendimento teria convertido a escolarização em um projeto de regeneração moral e física dos educandos, de modo que, tanto as alocuções pedagógicas quanto as convocações médico-higiênicas concorreriam para converter a Escola Nova em um grande aparato de vigilância, consagrando o ambiente escolar como um espaço de policiamento dos corpos e das almas dos infantes.

Desse modo, optamos por nomear nosso gesto analítico sob o termo visualização. A partir dela, excluímos as representações e instituímos os cânones. Estes, em nosso olhar, decalcam sentidos por meio de imagens. O verbo imagear deveria aqui ser lido em uma acepção bem distante de descrever, narrar, pintar. Antes, sob a inspiração dos imageadores de corpos que produziram o Visible Human Project, tratar-se-ia de desenvolver um algoritmo capaz de criar uma visualização plena e adequadamente capturável por olhos de determinada formação cultural.

Em suma, tudo o que se poderia dizer acerca da história, cremos, consistiria em tão somente visualizações. Para que fosse possível estabelecer algo como histórico, obrigatoriamente se deveria assumir a natureza imageadora do empreendimento. Uma forja assumidamente arbitrária e radical, tão sádica quanto sarcástica. 


\section{Fontes}

\section{Periódicos médicos}

ANNAES BRASILIENSES DE MEDICINA, Rio de Janeiro: Emp. Typographica Dous de Dezembro - de Paula Brito Impressor da Casa Imperial, n. 7, abr. 1852.

ANNAES BRASILIENSES DE MEDICINA, Rio de Janeiro: Emp. Typographica Dous de Dezembro - de Paula Brito Impressor da Casa Imperial, n. 4, jan. 1853

ANNAES BRASILIENSES DE MEDICINA, Rio de Janeiro: Emp. Typographica Dous de Dezembro - de Paula Brito Impressor da Casa Imperial, n. 14, ago. 1862

ANNAES BRASILIENSES DE MEDICINA, Rio de Janeiro: Emp. Typographica Dous de Dezembro - de Paula Brito Impressor da Casa Imperial, n. 3, mar. 1863

REVISTA MEDICA BRASILEIRA. Rio de Janeiro: Typographia Imparcial de F. P. Brito, n. 1, mai. 1841.

REVISTA MEDICA BRASILEIRA. Rio de Janeiro: Typographia Imparcial de F. P. Brito, n. 2, jun. 1841.

REVISTA MEDICA BRASILEIRA. Rio de Janeiro: Typographia Imparcial de F. P. Brito, n. 6, Out. 1841

REVISTA MEDICA BRASILEIRA. Rio de Janeiro: Typographia Imparcial de F. P. Brito, n. 7, nov. 1841.

REVISTA MEDICA BRASILEIRA. Rio de Janeiro: Typographia Imparcial de F. P. Brito, n. 3 , jul. 1842

REVISTA MEDICA BRASILEIRA. Rio de Janeiro: Typographia Imparcial de F. P. Brito, n. 6, out. 1842

REVISTA MEDICA BRASILEIRA. Rio de Janeiro: Typographia Imparcial de F. P. Brito, n. 10, fev. 1843

REVISTA MEDICA FLUMINENSE. Rio de Janeiro: Typographia Imparcial de F. P. Brito, n. 4 , jul. 1835.

REVISTA MEDICA FLUMINENSE. Rio de Janeiro: Typographia Imparcial de F. P. Brito, n. 7, out. 1835 .

REVISTA MEDICA FLUMINENSE. Rio de Janeiro: Typographia Imparcial de F. P. Brito, n. 1 , abr. 1836.

REVISTA MEDICA FLUMINENSE. Rio de Janeiro: Typographia Imparcial de F. P. Brito, n. 10, jan. 1841 . 


\section{Bibliotheca de Educação}

BARRETO, Ceição de Barros. Coro orfeão. São Paulo: Editora Melhoramentos, 1928. (Coleção Bibliotheca de Educação, v. XXVIII).

BINET, Alfred; SIMON, Theodore. Testes para medida do desenvolvimento da inteligência nas crianças. 3. ed. São Paulo, Caieiras, Rio: Companhia Melhoramentos de S. Paulo (Weiszflog Irmãos Incorporada), 1929. (Coleção Bibliotheca de Educação, v. X).

CLAPARÈDE, Édouard. A escola e a psychologia experimental. São Paulo, Caieiras, Rio: Companhia Melhoramentos de S. Paulo (Weiszflog Irmãos Incorporada), [1928]. (Coleção Bibliotheca de Educação, v. II).

COSTA, Firmino. Como ensinar linguagem no curso primário. São Paulo, Caieiras, Rio: Companhia Melhoramentos de S. Paulo (Weiszflog Irmãos Incorporada), [1932] (Coleção Bibliotheca de Educação, v. XVII)

CRESSON, André. Situação actual dos problemas philosophicos. São Paulo, Caieiras, Rio: Companhia Melhoramentos de S. Paulo (Weiszflog Irmãos Incorporada), [1931] (Coleção Bibliotheca de Educação, v. XIII).

DEWEY, John. Vida e educação. 3. ed. Tradução e estudo preliminar: Anísio Teixeira. São Paulo, Caieiras, Rio: Companhia Melhoramentos de S. Paulo (Weiszflog Irmãos Incorporada), 1952 (1. ed. 1930) (Coleção Bibliotheca de Educação, v. XII).

DOMINGUES, Octavio. A hereditariedade em face da educação. São Paulo, Caieiras, Rio: Companhia Melhoramentos de S. Paulo (Weiszflog Irmãos Incorporada), [1929]. (coleção Bibliotheca de Educação, v. VI).

DORIA, Antônio Sampaio. Educação moral e educação econômica: suas bases, sua aplicação nas escolas. São Paulo, Caieiras, Rio: Companhia Melhoramentos de S. Paulo (Weiszflog Irmãos Incorporada), [1928]. (Coleção Bibliotheca de Educação, v. III).

DURKHEIM, Émile. Educação e sociologia. São Paulo, Caieiras, Rio: Companhia Melhoramentos de S. Paulo (Weiszflog Irmãos Incorporada), [1929] (Coleção Bibliotheca de Educação, v. V).

FERRIÈRE, Adolpho. A lei biogenética e a escola activa. São Paulo, Caieiras, Rio: Companhia Melhoramentos de S. Paulo (Weiszflog Irmãos Incorporada) [1929] (Coleção Bibliotheca de Educação, v. IX).

FONSECA, Coryntho da. A escola activa e os trabalhos manuaes. São Paulo, Caieiras, Rio: Companhia Melhoramentos de S. Paulo (Weiszflog Irmãos Incorporada) [1929]. (Coleção Bibliotheca de Educação, v. VIII).

GEENEN, Henrique. Temperamento e carácter sob o ponto de vista educativo. São Paulo, Caieiras, Rio: Companhia Melhoramentos de S. Paulo (Weiszflog Irmãos Incorporada) [1929] (Coleção Bibliotheca de Educação, v. IV).

KILPATRICK, William Heard. Educação para uma civilisação em mudança. São Paulo, Caieiras, Rio: Companhia Melhoramentos de S. Paulo (Weiszflog Irmãos Incorporada) [1933] (Coleção Bibliotheca de Educação, v. XVIII).

LOURENÇO FILHO, Manoel Bergström. Testes ABC para verificação da maturidade necessaria á aprendizagem da leitura e escrita. 2. ed. São Paulo, Cayeiras, Rio de Janeiro: 
Companhia Melhoramentos de São Paulo (Weiszflog Irmãos Incorporada), [1937] (1. ed. 1933) (Coleção Bibliotheca de Educação, v. XX).

LOURENÇO FILHO, Manuel Bergström. Introdução ao estudo da escola nova. São Paulo, Caieiras, Rio: Companhia Melhoramentos de S. Paulo (Weiszflog Irmãos Incorporada) [1930] (Coleção Bibliotheca de Educação, v. XI)

LOURENÇO FILHO, Manuel Bergström. Tendencias da educação brasileira. São Paulo, Caieiras, Rio: Companhia Melhoramentos de S. Paulo (Weiszflog Irmãos Incorporada) [1941] (Coleção Bibliotheca de Educação, v. XXIX)

LUZURIAGA, Lorenzo. A escola única. São Paulo, Caieiras, Rio: Companhia Melhoramentos de S. Paulo (Weiszflog Irmãos Incorporada) [1934] (Coleção Bibliotheca de Educação, v. XXII).

MARQUES, Orminda Isabel. A escrita na escola primaria. São Paulo, Caieiras, Rio: Companhia Melhoramentos de S. Paulo (Weiszflog Irmãos Incorporada) [1936] (Coleção Bibliotheca de Educação, v. XXVI).

MOURA, Abner de. Os "centros de interesse" na escola: sugestões para lições globalizadas, segundo o systema Decroly, como contribuição a uma escola brasileira renovada. São Paulo, Caieiras, Rio: Companhia Melhoramentos de S. Paulo (Weiszflog Irmãos Incorporada) [1931] (Coleção Bibliotheca de Educação, v. XV).

PIÉRON, Henri. Psychologia experimental. São Paulo, Caieiras, Rio: Companhia Melhoramentos de S. Paulo (Weiszflog Irmãos Incorporada) [1927]. (Coleção Bibliotheca de Educação, v. I).

PINTO, Estevão. A escola e a formação da mentalidade popular do Brasil. São Paulo, Caieiras, Rio: Companhia Melhoramentos de S. Paulo (Weiszflog Irmãos Incorporada) [1931] (Coleção Bibliotheca de Educação, v. XVI).

PROENÇA, Antonio F. Como se ensina geographia. São Paulo, Caieiras, Rio: Companhia Melhoramentos de S. Paulo (Weiszflog Irmãos Incorporada) [1928]. (Coleção Bibliotheca de Educação, v. VII).

SERRANO, Jonathas. Como se ensina história. São Paulo, Caieiras, Rio: Companhia Melhoramentos de S. Paulo (Weiszflog Irmãos Incorporada) [1935] (Coleção Bibliotheca de Educação, v. XXV).

SERRANO, Jonathas; VENANCIO FILHO, Francisco. Cinema e educação. São Paulo, Caieiras, Rio: Companhia Melhoramentos de S. Paulo (Weiszflog Irmãos Incorporada) [1931] (Coleção Bibliotheca de Educação, v. XIV).

SIMON, Theodore. Prefácio. In: BINET, Alfred; SIMON, Theodore. Testes para medida do desenvolvimento da inteligência nas crianças. 3. ed. São Paulo, Caieiras, Rio: Companhia Melhoramentos de S. Paulo (Weiszflog Irmãos Incorporada), 1929. (Coleção Bibliotheca de Educação, v. X). 


\section{Periódicos educacionais}

ARAGÃO, Ediógenes. Raça, nação, classe e a educação para o trabalho: a marginalização do trabalhador nacional livre na primeira industrialização em São Paulo (1880-1920). ProPosições, Campinas, v. 14, n. 2 (41), p. 147-175, maio/ago. 2003.

ASCOLANI, Adrián. Libros de lectura en la escuela primaria argentina: civilizando al niño urbano y urbanizando al niño campesino (1900-1946). Educação em Revista, Belo Horizonte, v. 26, n. 1, p. 303-326, abr. 2010.

AZEVEDO, Fernanda Vicente de; BOMBASSARO, Ticiane; VAZ, Alexandre Fernandes. Escolarização do corpo e controle de si na Revista Estudos Educacionais. Revista Brasileira de Estudos Pedagógicos, Brasília, v. 92, n. 231, p. 302-315, maio/ago. 2011.

BASSINELLO, Greicilene A. Hespanhol. A saúde nos parâmetros curriculares nacionais: considerações a partir dos manuais de higiene. Educação Temática Digital, Campinas, v. 6, n. 1, p. 34-47, dez. 2004.

BORTOLOTTI, Karen Fernanda; CUNHA, Marcus Vinicius da. Anísio Teixeira e a psicologia: o valor da mensuração. Revista Brasileira de Estudos Pedagógicos, Brasília, v. 94, n. 236, p. 32-52, abr. 2013.

CAMPOS, Roselane Fátima; SHIROMA, Eneida Oto. O resgate da Escola Nova pelas reformas educacionais contemporâneas. Revistas Brasileira de Estudos Pedagógicos, Brasília, v. 80, n. 196, p. 483-493, set./dez. 1999.

CARVALHO, João Bosco Pitombeira et al. Euclides Roxo e o movimento de reforma do ensino de Matemática na década de 30. Revista Brasileira de Estudos Pedagógicos, v. 81, n. 199, p. 415-424, set./dez. 2000.

CUNHA, Marcus Vinicius da. Dewey e Piaget no Brasil dos anos trinta. Cadernos de Pesquisa, São Paulo, n. 97, p. 5-12, mai. 1996.

A desqualificação da família para educar. Cadernos de Pesquisa, São Paulo, n. 102, p. 46-64, nov. 1997.

Marcus Vinicius da. Três versões do pragmatismo deweyano no Brasil dos anos cinquenta. Educação e Pesquisa, São Paulo, v. 25, n. 2, p. 39-55, jul./dez. 1999a.

. Marcus Vinícius da. A presença John Dewey na constituição do ideário educacional renovador. Educação em Revista, Belo Horizonte, n. 30, p. 77-91, dez. 1999b.

Marcus Vinicius da. John Dewey: filosofia, política e educação. Perspectiva. Florianópolis, v. 19, n. 2, p. 371-388, jul./dez. 2001.

CUNHA, Marcus Vinicius da; SOUZA, Aline Vieira de. Cecília Meireles e o temático da Escola Nova. Cadernos de Pesquisa, v. 41, n. 144, p. 850-865, set./dez. 2011.

CUNHA JUNIOR, Carlos Fernandes Ferreira. Práticas corporais em Juiz de Fora (18761915). Pro-Posições, Campinas, v. 22, n. 3(66), p. 51-65, set./dez. 2011.

DINIZ, Antunes Aires. O ensino dos anormais: preocupações em Coimbra e em Portugal no início do século XX. Educar em Revista, Curitiba, n. 23, p. 245-263, 2004.

DUARTE, Newton. Concepções afirmativas e negativas sobre o ato de ensinar. Cadernos CEDES, Campinas. v. 19, n. 44, p. 85-106, abr. 1998. 
DUSSEL, Inés. Cuando las aparencias no engañan: una historia comparada de los uniformes escolares en Argentina y Estados Unidos (siglos XIX-XX). Proposições, v. 16, n. 1(46), p. 65-86, jan./abr., 2005.

FAZENDA, Ivani Catarina Arantes; SOUZA, Fernando César de. Diálogos interdisciplinares em saúde e educação: a arte de cuidar. Educação \& Sociedade, Porto Alegre, v. 37, n. 1, p. 107-124, jan./abr. 2012.

FERREIRA, Antonio Gomes. A criança e o seu desenvolvimento em discursos médicos e pedagógicos que circularam no contexto português (séculos XVIII a XX). Educação em Revista, Belo Horizonte, v. 26, n. 1, p. 215-234, abr. 2010.

FERREIRA, António Gomes; GONDRA, José Gonçalves. Idades da vida, infância e a racionalidade médico-higiênica em Portugal e no Brasil (séculos 17-19). Revista Brasileira de Estudos Pedagógicos, v. 87, n. 216, p. 119-134, maio/ago. 2006.

FREITAS, Itamar. História e Escola Nova: as inovações do professor Cesário Júnior para o ensino secundário em São Paulo (1928/1936). Revista de Educação Pública, v.16, n. 30, p. 163-176, jan./abr. 2007.

GARCIA, Ronaldo Aurélio Gimenes. Educação e psicanálise: a criança problema na perspectiva de análise da obra de Arthur Ramos (Rio de Janeiro 1930-1940). Praxis Educativa, Ponta Grossa, v. 1, n. 2, p. 65-76, jul./dez. 2006.

GLEYSE, Jacques; SOARES, Carmen Lucia. Os manuais escolares franceses de educação física, de higiene e de moral seriam sexistas? (1880-2004). Educação \& Sociedade, Campinas, v. 29, n. 102, p. 137-156, jan./abr. 2008.

GONDRA, José Gonçalves. A emergência da infância. Educação em Revista, Belo Horizonte, v. 26, n. 1, p. 195-214, abr. 2010

GUIMARÃES, Paula Crisitina David. A atuação das "instituições auxiliares da escola" sobre educação da infância mineira na década de 1920. Educação em Revista, Belo Horizonte, v. 29, n. 4, p. 149-166, dez. 2013.

KUHLMANN JR., Moisés. Histórias da educação infantil brasileira. Revista Brasileira de Educação, Rio de Janeiro, n. 14, p. 5-18, maio/jun./jul./ago. 2000.

KUHLMANN JR., Moysés; MAGALHÃES, Maria das Graças Saudi. A infância nos almanaques. Educação em Revista, Belo Horizonte, v. 26, n. 1, p. 327-350, abr. 2010.

MARQUES, Vera Regina Beltrão. Histórias de higienização pelo trabalho: crianças paranaenses no novecentos. Cadernos CEDES, Campinas, v. 23, n. 59, p. 57-78, abr. 2003.

MARQUES, Vera Regina Beltrão; FARIAS, Fabiana Costa de Senna Ávila. "Façamos dessa gente um elemento seguro do nosso progresso material e moral". A inspeção médico-escolar no Paraná dos anos 1920. Educação em Revista, Belo Horizonte, v. 26, n. 1, p. 287-302, abr. 2010.

MARTINS, Liane Maria Bertucci. 'Conselhos ao povo': educação contra a influenza de 1918. Cadernos CEDES, Campinas, v. 23, p. 103-117, abr. 2003.

MARTINS, Valter. Policiais e populares: educadores, educandos e higiene social. Cadernos CEDES, Campinas, v. 23, n. 59, p. 79-90, abr. 2003.

MENDONÇA, Ana Waleska P. C. et al. Pragamatismo e desenvolvimentismo dos anos 1950/1960. Revista Brasileira de Educação, p. 96-113, v.11, n.31, jan./abr., 2006. 
MOCTEZUMA, Lucia Martínez. Representaciones del cuerpo infantil em los libros de texto mexicanos, 1880-1940. Pro-Posições, Campinas, v. 22, n. 3(66), p. 35-49, set./dez., 2011

MOGILKA, Maurício. Educar para a democracia. Cadernos de Pesquisa, São Paulo, n. 119, p. 129-146, jul. 2003.

MOURA, Francisco; SILVA, Talitha Elen. A educação clínica como metodologia pedagógica: investigação sobre a aplicação da psicanálise na área educacional em Minas Gerais. Educação em Revista, Belo Horizonte, v. 25, n. 1, p. 265-291, jan. 2009.

MURARO, Darcísio Natal. Relações entre a filosofia e a educação de John Dewey e de Paulo Freire. Educação \& Realidade, Porto Alegre, v. 38, n. 3, p. 813-829, jul./set. 2013.

NÓBREGA, Danielle Oliveira da. Histórias de relação de poder: os (des)caminhos do atendimento às pessoas com deficiência mental. Revista Educação em Questão, v. 23, n. 9, p. 134-159, maio/ago. 2005.

NUNES, Clarice. Historiografia comparada da escola nova: algumas questões. Revista da Faculdade de Educação, São Paulo, v. 19, n. 1, p. 105-125, jan./jun. 1998.

POZATTI, Marco Luiz. Educação para a inteireza do ser: uma caminhada. Educação \& Realidade, Porto Alegre, v. 37, n. 1, p. 143-159, jan./abr. 2012.

RIBEIRO, Marlene. Política educacional para populações camponesas: da aparência à essência. Revista Brasileira de Educação, v. 18, n. 54, p. 669-691, jul./set. 2013.

RICHTER, Ana Cristina; VAZ, Alexandre Fernandes. Educar e cuidar do corpo: biopolítica no atendimento à pequena infância. Educação em Revista, Belo Horizonte, v. 29, n. 4, p. 117-134, ago. 2010.

ROCHA, Heloisa Pimenta. Prescrevendo regras de bem viver: cultura escolar e racionalidade científica. Cadernos CEDES, Campinas, v. 20, n. 52, p. 55-73, nov. 2000.

A educação da infância: entre a família e a medicina. Educação em Revista, v. 26, n. 1, p. 235-262, abr. 2010.

Alfabetização, saneamento e regeneração nas iniciativas de difusão da escola primária em São Paulo. Pro-Posições, Campinas, v. 22, n. 2(65), p. 151-172, maio/ago. 2011.

ROCHA, Heloisa Pimenta; GONDRA, José Gonçalves. A escola e a produção de sujeitos higienizados. Perspectiva, Florianópolis, v. 20, n. 2, p. 493-512, jul./dez. 2002.

SANTOS, Heloísa Occhiuzedos. Ideário pedagógico municipalista de Anísio Teixeira. Cadernos de Pesquisa, n. 10, p. 105-124, jul. 2000.

SCHARAGRODSKY, Pablo. El padre de la educacion fisica argentina: fabricando una politica corporal generalizada (1900-1940). Perspectiva, Florianópolis, v. 22, n. especial, p. 83-119, jul./dez. 2004.

SILVA, André Luiz dos S. Imperativos da beleza: corpo feminino, cultura fitness e a nova eugenia. Cadernos CEDES, Campinas, v. 32 n. 87, p. 211-222, maio/ago. 2012.

SILVA, João Carlos da. O tema da escola pública no manifesto dos pioneiros da Escola Nova. Revista Brasileira de Educação Pública, v. 20, n. 44, p. 521-539, set./dez. 2011.

SIRCILLI, Fabíola. Arthur Ramos e Anísio Teixeira na década de 1930. Revista Paidéia, Ribeirão Preto, v. 15, n. 31, p. 185-193, 2005. 
SPAZZIANI, Maria de Lourdes. A saúde na escola: da medicalização à perspectiva da psicologia histórico-cultural. Educação Temática Digital, Campinas, v. 3, n. 1, p. 41-62, dez. 2001.

TELES, Ana Maria Orofino; CERQUEIRA, Teresa Cristina Siqueira. A pedagogia do si mesmo: debate sobre a emergência do sujeito que aprende. Educação \& Realidade, Porto Alegre, v. 38, n. 3, p. 931-951, jul./set. 2013.

VALE, Antonio Marques do. Abordagem sobre um tema complexo de história: a relação entre finalidades da educação, poder e interesses. Praxis Educativa, Ponta Grossa, v. 4, n. 1, p. 4150, jan./jun. 2009.

VEIGA, Cynthia Greive. Escola de alma branca o direito biológico à educação no movimento da escola nova. Educação em Revista, Belo Horizonte, n. especial, p. 123-150, 2000.

VENERA, Raquel Alvarenga Sena. Sentidos da educação cidadã no Brasil. Educar em Revista, Curitiba, n. 34, p. 231-240, 2009.

VIDAL, Diana Gonçalves. Da caligrafia à escrita: experiências escolanovistas com caligrafia muscular nos anos 30. Revista da Faculdade de Educação, São Paulo, v. 24, n. 1, p. 126140, jan./jun.1998.

YAZLLE, Elisabeth Gelli; FERNANDES, Juliana G. D. A presença de idéias higienistas e compensatórias na formação de professores para a educação infantil. Educação, Porto Alegre, v. 32, n. 2, p. 201-209, maio/ago. 2009. 


\section{Referências}

AQUINO, Julio Groppa. Instantâneos da escola contemporânea. Campinas: Papirus, 2007.

Pedagogização do pedagógico: sobre o jogo do expert no governamento docente. Educação, Porto Alegre, v. 36, n. 2, p. 201-209, maio/ago. 2013.

ARCE, Alessandra; SIMÃO, Rosimeire. A psicologia da criança e a pedagogia fundional de Edouard Claparéde e a pedagogia dos jardins de infância de Friedrich Froebel: continuidades e rupturas no pensamento de dois autores defensores de uma escola progressista. Revista HISTEDBR, Campinas, n. 28, p. 38-56, dez. 2007.

ARIÈS, Philippe. A história das mentalidades. In: NOVAIS, Fernando A.; SILVA, Rogerio F. (orgs). Nova História em perspectiva. São Paulo: Cosac Naify, 2011. p. 268-295.

História social da criança e da família. Rio de Janeiro: LTC, 2012.

AZIZE, Rogerio Lopes. O cérebro como órgão pessoal: uma antropologia de discursos neurocientíficos. Trabalho, Educação e Saúde, Rio de Janeiro, v. 8, n. 3, p. 563-574, nov. 2010/fev. 2011.

BEAR, Mark F. Neurociências: desvendando o sistema nervoso. Porto Alegre: Artmed, 2002.

BEERS, Whittngham Clifford. Um espírito que se achou a si mesmo. São Paulo: Companhia Editora Nacional, 1934.

BENASAYAG, León ¿Medicina \& marketing ó marketing em medicina? In: COLLARES, Cecilia Azevedo Lima; MOYSÉS, Maria Aparecida Affonso; RIBEIRO, Monica Cintrão França Ribeiro (Orgs.). Novas capturas, antigos diagnósticos na era dos transtornos: memória do II Seminário Internacional - A Educação Medicalizada: dislexia, TDAH e outros supostos transtornos. Campinas: Mercado de Letras, 2013. p. 149-168.

BENCZIK, Edyleine Bellini Peroni. Transtorno do déficit de atenção/ hiperatividade: um guia de orientação para profissionais. São Paulo: Casa do Psicólogo, 2000.

BORING, Edwin G. Intelligence as the tests test it. New Republic, n. 36, p. 35-37, 1923. Disponível em: <http://www.brocku.ca/MeadProject/sup/Boring_1923.html>. Acesso em: 22 nov. 2013.

BRASIL. Secretaria de Educação Fundamental. Parâmetros curriculares nacionais: introdução aos parâmetros curriculares nacionais. Brasília: MEC/SEF, 1997.

BRENNER, Sydney. Genomics and a scientifically responsible ethics. BioSocieties, London, V. 1, p. 7-12, 2006.

BURRI, Regula Valérie; DUMIT, Joseph. Social Studies of Scientific Imaging and Visualization. In: HACKETT, Ed. et al. The handbook of science and technology studies. Cambridge: MIT Press, 2007. p. 297-317.

CALLIMAN, Luciana Vieira. O bio-diagnóstico na era das cidadanias biológicas. In: COLLARES, Cecilia Azevedo Lima; MOYSÉS, Maria Aparecida Affonso; RIBEIRO, Monica Cintrão França Ribeiro (Orgs.). Novas capturas, antigos diagnósticos na era dos transtornos: memória do II Seminário Internacional - A Educação Medicalizada: dislexia, TDAH e outros supostos transtornos. Campinas: Mercado de Letras, 2013. p. 109-118. 
CANGUILHEM, Georges. Escritos sobre medicina. Rio de Janeiro: Forense Universitária, 2005.

. O cérebro e o pensamento. Natureza humana, n.1, p. 183- 210, 2006a.

O normal e o patológico. Rio e Janeiro: Forense Universitária, 2006b.

CARVALHO, Marta Maria Chagas de. Modernidade pedagógica e modelos de formação docente. São Paulo em Perspectiva, São Paulo, v. 14, n. 1, p. 111-120, jan./mar. 2000.

Quando a história da educação é a história da disciplina e da higienização das pessoas. In: FREITAS, Marcos Cezar de (Org.). História social da infância no Brasil. São Paulo: Cortez, 2006. p. 291-310.

Estratégias editoriais e territorialização do campo pedagógico: um livro de Sampaio Dória sob pena do editor da Bibliotheca de Educação. História da Educação, Porto Alegre, v. 17, n. 39, p. 39-56, jan./abr. 2013.

CARVALHO, Marta Maria Chagas de; TOLEDO, Maria Rita de Almeida. A Bibliotheca da Educação de Lourenço Filho: uma coleção a serviço de um projeto de inovação pedagógica. Quaestio - Revista de Estudos de Educação, Sorocaba, v. 8, n. 2, p. 47-62, nov. 2006.

CHABANNE. Jean-Luc. Dificuldades de aprendizagem: um enfoque inovador do ensino escolar. São Paulo: Ática, 2008.

CHARTIER, Roger. O mundo como representação. Revista Estudos Avançados, São Paulo, v. 5, n. 11, p. 173-191, jan./abr. 1991.

COLL, César et al. O construtivismo na sala de aula. São Paulo: Ática, 2004.

COLLARES, Cecília Azevedo Lima. O cotidiano escolar patologizado: espaços de preconceitos e práticas cristalizadas. Tese (Livre-Docência) - Faculdade de Educação, Universidade Estadual de Campinas, Campinas, 1995.

COLLARES, Cecilia Azevedo Lima; MOYSÉS, Maria Aparecida Affonso; RIBEIRO, Monica Cintrão França. Apresentação. In: (Orgs.) Novas capturas, antigos diagnósticos na era dos transtornos: memória do II Seminário Internacional - A Educação Medicalizada: dislexia, TDAH e outros supostos transtornos. Campinas: Mercado de Letras, 2013. p. 15-20.

COSTA, Jurandir Freire. Comunicação oral. In: CONGRESSO BRASILEIRO DE SAÚDE COLETIVA, 6., 2000, Salvador. Anais [CD-ROM]. Salvador: ABRASCO, 2000.

DAMÁSIO, António Rosa. O erro de Descartes: emoção, razão e cérebro humano. São Paulo: Companhia das Letras, 1996.

D’AVILA, Jerry. Diploma de brancura: política social e racial no Brasil. 1917-1945. São Paulo: Editora UNESP, 2006.

DIAS, Fernando Correia. Durkheim e a sociologia da educação no Brasil. Em Aberto, Brasília, ano 9, n. 46, p. 33-48, abr./jun. 1990.

DOMINGUES, Octavio. Eugenia: seus propósitos suas bases, seus meios em cinco lições. São Paulo: Companhia Editora Nacional, 1933.

DONATO, Hernâni. 100 anos da Melhoramentos. São Paulo: Melhoramentos, 1990.

DUBY, Georges (Org.). História da vida privada 2: da Europa feudal à renascença. São Paulo: Companhia das Letras, 1990. 
FARAONE, Silvia; BIANCHI, Eugenia. Medicalization de la infância a traves del analisis del transtorno por déficit de atención com hiperatividade (TDAH) em Argentina: usuários, psicofarmacos y manuales de diagnostico. In: COLLARES, Cecilia Azevedo Lima; MOYSÉS, Maria Aparecida Affonso; RIBEIRO, Monica Cintrão França (Orgs.). Novas capturas, antigos diagnósticos na era dos transtornos: memória do II Seminário Internacional - A Educação Medicalizada: dislexia, TDAH e outros supostos transtornos. Campinas: Mercado de Letras, 2013. p. 93-107.

FAUCONNET, Paul. Apresentação. In: DURKHEIM, Émile. Educação e sociologia. São Paulo: Companhia Melhoramentos de S. Paulo, 1929 (Coleção Bibliotheca de Educação, v. V).

FERREIRA, Luiz Otavio. O nascimento de uma instituição científica: o periódico médico brasileiro da primeira metade do século XIX. Tese (Doutorado) - Faculdade de Filosofia, Letras e Ciências Humanas, Universidade de São Paulo, São Paulo, 1996.

FERREIRA, Walter Motta (Org.). Zootecnia brasileira: quarenta anos de histórias e reflexões. Recife: UFRPE, Imprensa Universitária, 2006.

FIGUEIREDO, Paulo Henrique de. Mesmer: a ciência negada e os textos escondidos. Bragança Paulista: Lachâtre, 2005.

FOUCAULT, Michel. Vigiar e punir: história da violência nas prisões. Petrópolis: Vozes, 1987.

O sujeito e o poder. In. DREYFUS, Hubert; RABINOW, Paul. Michel Foucault, uma trajetória filosófica. Rio de Janeiro: Forense Universitária, 1995. p. 231- 249.

As palavras e as coisas. São Paulo: Martins Fontes, 1999a.

Em defesa da sociedade: curso dado no Collège de France (1974-1975). São Paulo: Martins Fontes, 1999b.

Raymond Roussel. Rio de Janeiro: Forense Universitária, 1999c.

2001a.

A verdade e as formas jurídicas. Rio de Janeiro: Pontifícia Universidade Católica,

Os anormais: curso dado no Collège de France (1974-1975). São Paulo: Martins Fontes, 2001b.

A psicologia de 1850 a 1950. In:

Problematização do sujeito: psicologia, psiquiatria e psicanálise. Organização e seleção de textos, Manoel Barros da Motta. Tradução de Vera Lucia Avellar Ribeiro. Rio de Janeiro: Forense Universitária, 2002. p. 133-164 (Ditos \& Escritos I).

História da loucura na idade clássica. São Paulo: Perspectiva, 2003.

Nietzsche, a genealogia e a história. In: e tradução de Roberto Machado. Rio de Janeiro: Graal, 2004a.

O nascimento da clínica. Rio de Janeiro: Forense Universitária, 2004b.

O poder psiquiátrico: curso dado no Collège de France (1973-1974). São Paulo: Martins Fontes, 2006.

A arqueologia do saber. Rio de Janeiro: Forense Universitária, 2007. 
Nascimento da biopolítica. curso dado no Collège de France (1978-1979). São Paulo, Martins Fontes, 2008a.

Segurança, território, população: curso dado no Collège de France (1977-1978). São Paulo, Martins Fontes, 2008b.

A hermenêutica do sujeito: curso dado no Collège de France (1981-1982). São Paulo: WMF Martins Fontes, 2010a.

O governo de si e dos outros: curso dado no Collège de France (1982-1983). São Paulo: WMF Martins Fontes, 2010b.

Prefácio (Anti-Édipo). In:

Repensar a política. Organização e seleção de textos por Manoel Barros da Motta. Tradução de Ana Lucia Paranhos. Rio de Janeiro: Forense Universitária, 2010c. p. 103-106 (Ditos \& Escritos VI).

A coragem da verdade: curso no Collège de France (1983-1984). São Paulo: WMF Martins Fontes, 2011.

Do governo dos vivos: curso no Collège de France (1979-1980). São Paulo: WMF Martins Fontes, 2014.

GARCIA, Sanchez; JESUS, Nicasio. Dificuldades de aprendizagem e intervenção psicopedagógica. Porto Alegre: Artmed, 2004.

GONDRA, José Gonçalves. Artes de civilizar: medicina, higiene e educação escolar na corte imperial. Rio de Janeiro: Editora UERJ, 2004.

HACKING, Ian. The cartesia vision fulfilled: analogue bodies and digital minds. Interdisciplinary Science Reviews, v. 30, n. 2, p. 153-166, 2005.

HERSCHMANN, Micael. Entre a insalubridade e a ignorância: a construção do campo médico no Brasil. In: HERSCHMANN, Micael; KROPF, Simone; NUNES, Clarice. Missionários do progresso: médicos, engenheiros e educadores no Rio de Janeiro - 18701937. Rio de Janeiro: Diadorim, 1996.

IRIART, Celia; IGLESIAS-RIOS, Lisbeth. La (re)creacion del consumidor de salud y la biomedicalizacion de la infância. In: COLLARES, Cecilia Azevedo Lima; MOYSÉS, Maria Aparecida Affonso; RIBEIRO, Monica Cintrão França (Orgs.). Novas capturas, antigos diagnósticos na era dos transtornos: memória do II Seminário Internacional - A Educação Medicalizada: dislexia, TDAH e outros supostos transtornos. Campinas: Mercado de Letras, 2013. p. 21-40.

LA TAILlE, Yves de; OLIVEIRA, Marta Kohl de; DANTAS, Heloysa. Piaget, Vygotsky, Wallon: teorias psicogenéticas em discussão. São Paulo: Summus, 1992.

LIMA, Rossano Cabral. Somos todos desatentos? O TDA/H e a construção de bioidentidades. Rio de Janeiro: Relume Dumará, 2005.

LOBO, Lilian Ferreira. Os infames da história: a instituição das deficiências no Brasil. Tese (Doutorado) - Pontifícia Universidade Católica, Rio de Janeiro, 1997.

LOURENÇO FILHO, Manuel Bergström. Apresentação. In: PIÉRON, Henri. Psychologia experimental. São Paulo: Companhia Melhoramentos de S. Paulo, 1927. (Coleção Bibliotheca de Educação, v. I). 
Prefácio. In: CLAPARÈDE, Édouard. A escola e a psychologia experimental. Tradução: Lourenço Filho. São Paulo: Companhia Melhoramentos de S. Paulo, 1928. (Coleção Bibliotheca de Educação, v. II).

Prefácio. In: CRESSON, André. Situação actual dos problemas philosophicos. São Paulo, Caieiras, Rio: Companhia Melhoramentos de S. Paulo (Weiszflog Irmãos Incorporada), [1931a] (Coleção Bibliotheca de Educação, v. XIII).

Prefácio. In: MOURA, Abner de. Os "centros de interesse" na escola: sugestões para lições globalizadas, segundo o systema Decroly, como contribuição a uma escola brasileira renovada. São Paulo, Caieiras, Rio: Companhia Melhoramentos de S. Paulo (Weiszflog Irmãos Incorporada), [1931b] (Coleção Bibliotheca de Educação, v. XV).

Introdução aos estudos da escola nova. São Paulo: Melhoramentos, 1963.

MACHADO, Adriana Marcondes. Reinventando a avaliação psicológica. Tese (Doutorado) - Instituto de Psicologia, Universidade de São Paulo, São Paulo, 1996.

MACHADO, Roberto et al. Da(n)ação da norma: medicina social e constituição da psiquiatria no Brasil. Rio de Janeiro: Graal, 1978.

MAGNANI, Maria do Rosário Mortatti. Testes ABC e a fundação de uma tradição: alfabetização sob medida. In: MONARCHA, Carlos (Org.). Lourenço Filho: outros aspectos, mesma obra. Campinas: Mercado de Letras - UNESP, 1997. p. 59-90.

MARTIN, Emily. The pharmaceutical person. BioSocieties, London, v.1, p. 273-287, 2006.

MATE, Cecília Hanna. Tempos modernos na escola: os anos 30 e a racionalidade da educação brasileira. Bauru: EDUSC, 2002.

MATHIESON, Louisa Campbell. O militante e o pedagogo Antonio de Sampaio Doria: a formação do cidadão republicano. Dissertação (Mestrado em Educação) - Faculdade de Educação, Universidade de São Paulo, São Paulo, 2012

MATTOS, Paulo. No mundo da lua: perguntas e respostas sobre o transtorno do déficit de atenção em crianças, adolescentes e adultos. São Paulo: Lemos Editorial, 2001.

MESMER, Frank Anton. Memória sobre a descoberta do magnetismo animal. In: FIGUEIREDO, Paulo Henrique de. Mesmer: a ciência negada e os textos escondidos. Bragança Paulista: Lachâtre, 2005. p. 301-337.

MONARCHA, Carlos (Org.). Lourenço Filho: outros aspectos, mesma obra. Campinas: Mercado de Letras - UNESP, 1997.

Escola normal da praça: o lado noturno das luzes. Campinas: Editora da UNICAMP, 1999.

(Org.). Educação da infância brasileira: 1875/1983. Campinas: Autores Associados, 2001a.

Lourenço Filho e a organização da psicologia aplicada à educação. São Paulo: Instituto Nacional de Estudos e Pesquisas Educacionais, $2001 \mathrm{~b}$.

MOYSÉS, Maria Aparecida Affonso; COLLARES, Cecília Azevedo Lima. Medicalização: o obscurantismo reinventado. In: COLLARES, Cecilia Azevedo Lima; MOYSÉS, Maria Aparecida Affonso; RIBEIRO, Monica Cintrão França (Orgs.). Novas capturas, antigos diagnósticos na era dos transtornos: memória do II Seminário Internacional - A Educação 
Medicalizada: dislexia, TDAH e outros supostos transtornos. Campinas: Mercado de Letras, 2013. p. 41-64.

NICOLELIS, Miguel. Muito além do nosso eu: a nova neurociência que une cérebros e máquinas e como ela pode mudar nossas vidas. São Paulo: Companhia das Letras, 2011.

Ó, Jorge Ramos do. O governo de si mesmo: modernidade pedagógica e encenações disciplinares do aluno liceal (último quartel do século XIX - meados do XX). Lisboa: Educa, 2003.

A “criança-problema" e seu governo em Portugal e no Brasil (1880-1960): discursos e práticas. In: Ó, Jorge Ramos do; CARVALHO, Luiz Miguel. Emergência e circulação do conhecimento psicopedagógico moderno (1880-1960): estudos comparados Brasil-Portugal. Lisboa: Educa, 2009.

OLIVEIRA, Felipe; SOUZA, Marilene Proença Rebello de. O que dizem os projetos de lei sobre dislexia e transtorno de déficit de atenção e hiperatividade: contribuições da psicologia escolar. In: COLLARES, Cecilia Azevedo Lima; MOYSÉS, Maria Aparecida Affonso; RIBEIRO, Monica Cintrão França (Orgs.). Novas capturas, antigos diagnósticos na era dos transtornos: memória do II Seminário Internacional - A Educação Medicalizada: dislexia, TDAH e outros supostos transtornos. Campinas: Mercado de Letras, 2013. p. 203-219.

OLIVEIRA, Inês Barbosa de. $\mathrm{O}$ conhecimento na era dos transtornos: limites e possibilidades. In: COLLARES, Cecilia Azevedo Lima; MOYSÉS, Maria Aparecida Affonso; RIBEIRO, Monica Cintrão França (Orgs.). Novas capturas, antigos diagnósticos na era dos transtornos: memória do II Seminário Internacional - A Educação Medicalizada: dislexia, TDAH e outros supostos transtornos. Campinas: Mercado de Letras, 2013. p. 79-92.

ORTEGA, Francisco. Corpo e tecnologias de visualização médica: entre a fragmentação na cultura do espetáculo e a fenomenologia do corpo vivido. Physis: Revista de Saúde Coletiva, Rio de Janeiro, v. 15, n. 2, p. 237-257, 2005.

O corpo incerto: corporeidade, tecnologias médicas e cultura contemporânea. Rio de Janeiro: Garamond, 2008.

PATTO, Maria Helena de Souza. Psicologia e ideologia: uma crítica à psicologia escolar. São Paulo: T.A. Queirós, 1984.

A produção do fracasso escolar. São Paulo: Casa do Psicólogo, 1999.

PEIXOTO, Afrânio. Prefácio. In: BEERS, Whittngham Clifford. Um espírito que se achou a si mesmo. São Paulo: Companhia Editora Nacional, 1934.

. Noções de história da educação. São Paulo: Companhia Editora Nacional, 1936.

Um grande problema nacional: estudos sobre ensino secundário. São Paulo: Editora Anchieta, 1937.

PEREGRINO JR., João. Biotypologia e educação. Rio de Janeiro: Diretoria Nacional de Saude e Assistencia Medico-Social Secção de Informação, Propaganda e Educação Sanitária, 1936. (Coleção IPES - 2).

PRAINSACK, Barbara; SIEGAL Gil. The rise of genetic couplehood? A comparative view of premarital genetic testing. Biosocieties, London, v. 1, n. 1, p. 18-36, 2006.

PROENÇA, Marilene; ROCHA, Marisa Lopes da (Orgs.). Psicologia e educação: desafios teórico-práticos. São Paulo: Casa do Psicólogo, 2000. 
RABINOW, Paul. Antropologia da razão. Rio de Janeiro, Relume Dumará, 2002.

RAGO, Luzia Margareth. Do cabaré ao lar: a utopia da cidade disciplinar. Brasil (18901930). Rio de Janeiro: Paz e Terra, 1985.

RAMOS, Artur. A criança problema: a higiene mental na escola primária. Rio de Janeiro: Companhia Editora Nacional, 1939.

REIS, Jose Roberto Franco. De pequenino é que se torce o pepino: a infância nos programas eugênicos da Liga Brasileira de Higiene Mental. História, Ciência, Saúde, Manguinhos, v. 7, n. 1, p. 135-157, mar./jun. 2000.

RITO, Marcelo. O aluno-problema e o governo da alma: uma abordagem foucaultiana. Dissertação (Mestrado em Educação) - Faculdade de Educação, Universidade de São Paulo, São Paulo, 2009.

ROCHA, Heloisa Pimenta. A higienização dos costumes: educação escolar e saúde no projeto do Instituto de Hygiene de São Paulo (1918-1925). Campinas: Mercado de Letras, 2003.

ROHDE, Luis Augusto et al. Princípios e práticas em transtorno de déficit de atenção/hiperatividade. Porto Alegre, 2003.

ROSA, João Guimarães. Grande sertão: veredas. Rio de Janeiro: Nova Fronteira, 1986.

ROSE, Nikolas. El gobierno en las democracias liberales "avanzadas" del liberalismo al neoliberalismo. Archipiélago: Cuadernos de crítica de la cultura, n. 29, p. 25-40, 1997.

Inventando nossos eus. In: SILVA, Tomaz Tadeu da (Org.). Nunca fomos humanos. Belo Horizonte: Autêntica, 2001. p. 137-178.

Neurochemical selves. Society, Nova York, p. 46-59, nov./dez. 2003.

A política da própria vida: biomedicina, poder e subjetividade no século XXI. São Paulo: Paulus, 2013.

SCHWARCZ, Lilia Moritz. Espetáculo das raças: cientistas, instituições e questão racial no Brasil 1870-1930. São Paulo: Companhia das Letras, 1993.

SFEZ Lucien. A saúde perfeita: crítica de uma nova utopia. São Paulo: Edições Loyola, 1996.

SHELLEY, Mary. Frankenstein: o moderno prometeu. Porto Alegre: L\&PM, 1996.

SILVA, Ana Beatriz. Mentes inquietas: entendendo melhor o mundo das pessoas distraídas, impulsivas e hiperativas. Rio de Janeiro: Napades, 2003.

TEIXEIRA, Anísio. Estudo preliminar. In: DEWEY, John. Vida e educação. 3. ed. Tradução Anísio Teixeira. São Paulo, Caieiras, Rio: Companhia Melhoramentos de S. Paulo (Weiszflog Irmãos Incorporada), 1952 (1. ed. 1930) (Coleção Bibliotheca de Educação, v. XII).

TEMPORÃO, José Gomes. Indústria farmacêutica e medicalização. In: COLLARES, Cecilia Azevedo Lima; MOYSÉS, Maria Aparecida Affonso; RIBEIRO, Monica Cintrão França (Orgs.). Novas capturas, antigos diagnósticos na era dos transtornos: memória do II Seminário Internacional - A Educação Medicalizada: dislexia, TDAH e outros supostos transtornos. Campinas: Mercado de Letras, 2013. p. 65-78.

TERMAN, Lewis M. et al. The stanford revision and extension of the Binet-Simon Scale for Measuring Intelligence. Baltimore: Warwick \& York, Inc., 1917. 
TOLEDO, Maria Rita de Almeida; CARVALHO, Marta Maria Chagas de. A tradução de John Dewey publicada na coleção Biblioteca da educação. In: CONGRESSO BRASILEIRO DE HISTÓRIA DA EDUCAÇÃO, 7., 2013, Cuiabá. Anais... Cuiabá: Universidade Federal de Mato Grosso, 2013. Disponível em: 〈http://sbhe.org.br/novo/congressos/cbhe7>. Acesso em: 7. jan. 2015.

VEYNE, Paul. Como se escreve a história; Foucault revoluciona a história. Brasília: UnB, 1982.

Foucault, o pensamento, a pessoa. Lisboa: Edições Texto \& Grafia, 2009.

WALDBY, Catherine. The body and the digital archive: the Visible Human Project and the computerization of medicine. p. 227-243, abr. 1997. Disponível em: <http://hea.sageapub.com/content/1/2/227>. Acesso em: $28 \mathrm{dez} .2013$. 